San Jose State University

SJSU ScholarWorks

Master's Theses

Master's Theses and Graduate Research

1971

\title{
The Role of Defense Spending in Recent Economic Growth of the San Francisco Bay Area
}

James Calhoun Williams

San Jose State University

Follow this and additional works at: https://scholarworks.sjsu.edu/etd_theses

\section{Recommended Citation}

Williams, James Calhoun, "The Role of Defense Spending in Recent Economic Growth of the San Francisco Bay Area" (1971). Master's Theses. 4081.

DOI: https://doi.org/10.31979/etd.e9wr-eevp

https://scholarworks.sjsu.edu/etd_theses/4081

This Thesis is brought to you for free and open access by the Master's Theses and Graduate Research at SJSU ScholarWorks. It has been accepted for inclusion in Master's Theses by an authorized administrator of SJSU ScholarWorks. For more information, please contact scholarworks@sjsu.edu. 
THE ROLE OF DEFENSE SFENDING IN RECENT ECONOMIC GROWTH OF THE SAN FRANCISCO BAY AREA

\author{
A Thesis \\ Presented to \\ the Faculty of the Department of History \\ San Jose State College
}

In Partial Fulfiliment

of the Requirements for the Degree

Master of Arts

by

James Calhoun Williams

January 1971 
APPROVED FOR THE DEPARTMENT OF HISTORY

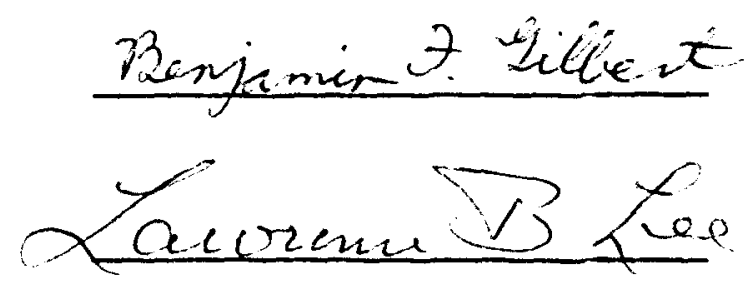

APPROVED FOR THE COLLEGE GRADUATE COMMITTEE

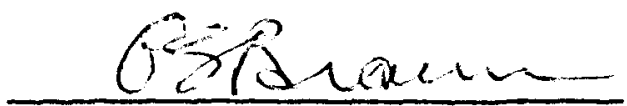


PREFACE

One of the most important developments in recent United States history has been the overwhelming Impact of defense expenditures on American society. Several Industrial areas of the country apparentiy have become economically dependent upon federal government contracts, and it has been widely suggested that the military and aerospace spending program has engendered signiflcant national political and phllosophical changes. It is generally assumed that the San Francisco Bay Area depends heavily upon derense and space contracts; yet no study has fully analyzed the historical growth, development, and economic impact of defense spending in this region. To what extent the Bay Area's Industrial base relies upon defense expenditures is not clear. Nor is it evident what factors caused the growth of the region's defense-oriented economy. Herein is the story of the development of the Bay Area's present Industrial base and an analysis of the real Impact of federal contracts upon the regional economy. Whereas my original intention was to explore the political and philosophical attitudes propagated among the residents of a region largely dependent upon national defense programs, I found that this was not feasible until 
the economic foundation had been established. What follows is that groundwork. Unfortunately, the limits set upon a paper of this nature made it inappropriate to proceed further. In future work, however, I hope to pursue the polftical and philosophical aspects of this problem.

I should like to express great appreciation to Professor Benjamin F. Gilbert of San Jose State College for his patience and sound advice. Additionally, my thanks go to Professor James $W$. Pratt, who originally inspired me to embark upon this Journey, and to Professor Lawrence B. Lee for his comments.

During the research period I solicited the assistance and advice of many persons. My thanks go particularly to Professor H. Brett Melendy of the University of Hawaii; Professor Guenter M. Conradus of San Jose State College; M1ss Christine Simpson, Documents Librarian at San Jose State College; Mr. George Aldridge, Librarian of the San Jose Mercury-News; and Miss Cheryl Rife, who assisted me during the summer of 1969. For those errors which may be found in statistical information presented in this work, I am alone responsible.

To my wife, Sandra, I owe the most, for her understanding and encouragement have made this adventure possible and worthwhile. 


\section{TABLE OF CONTENTS}

PREFACE ............................ 111

LIST OF TABLES ......................... vi

LIST OF ILLUSTRATIONS . . . . . . . . . . . vij.

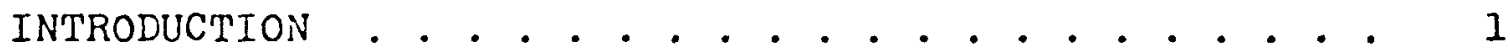

CHAPTER ONE: The War Perlod ......... 4

CHAPTER TWO: The Postwar Perlod . . . . . . . . 19

CHAPTER THREE: The Fifties--A Perlod of Growth . . . 43

CHAPTER FOUR: The Surge of Aerospace . . . . . . 72

CHAPTER FIVE: Measuring the Impact of Defense Spending on Area Grovlth ......... 990

CHAFTER SIX: The Impact of Defense Spending in the

Bay Area .. . . . . . . . 159

APPENDIX ONE: United States Government Expenditures . IZ8 APPENDIX TwO: Employment, Wages, and Inccine .... 194 APPENDIX THREE: Bay Area Manufacturing Markets . . . 200 APPENDIX FOUR: Bay Area Defense-Space Contracts . . 208

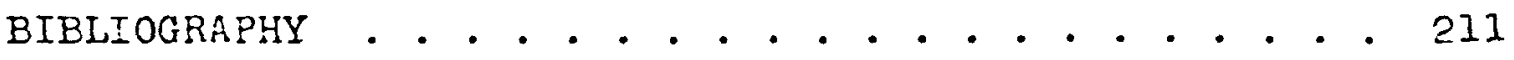




\section{LIST OF TABLES}

Table

Page

1. Major War Supply and Fac1l1ty Contracts and Allocations, 1 June, 1940 - 1 June, 1942 . . . 8

2. San Francisco Bay Area Wartime Population Increase 9

3. Approximate Estimates of Natural Increase and Net Migration into California by Years, 1940-1949. 10

4. Value to U.S. Government Cleared Primary Defense Contracts Awarded to San Francisco Bay Area Firms to September 21, 1941, by Industry-Groups

5. Employment Trends in Military-Related Manufacturing in the San Francisco Bay Area . 17

6. Nonmanufacturing and Nonconstruction Insured Employment Growth in the San Francisco Bay Area . 18

7. Federal Expenditures, Per Capita, in 1926 Prices, 1939-1952 . . . . . . . . . . . 20

8. New Construction Investment in California, $1939-1949$

9. Postwar Industrial Facil1ty Expansion and Cost, Cumulative Totals, 1945-1949. . . . . . . . 38

10. California Net Income Payments, 1939-1949 . • . 39

11. Nonmanufacturing Employment Increase in California and the Bay Area, 1947-1957 . . . . 49

12. San Francisco Bay Area Population Increase, $1950-1965$. . . . . . . . . . . . 58

13. Bay Area Retail Sales Growth, 1950-1960 . . . . 61

14. Nonmanufacturing Employment Increase in the Bay Area, 1960-1965 . . . . . . . . . 76

15. California M11itary Strength and Federal Civilian Employment 
16. Estimated Annual Department of Defense Military and Civilian Payrolis in California as a Percentage of Personal Income, 1946-1965 . . . 96

17. Value of $R$ \& $D$ Contracts to California and the Nation, 1961-1967 .......... 105

18. Relationship of Actual Expenditures to New Obligational Authority, USAR, Fiscal Years 1951-1953.

19. California Share of U.S. Defense-Space Contracts, 1951-1967

20. Department of Defense Prime and Unclassified Contract Awards to California and the Bay Area, Fiscal Years 1960, 1962, ana 1964 ......

21. Subcontracting as a Percentage of Prime Contract Payments, 1957-1963, by Prime Contractors . . . 121

22. Electronic Content: Average Percent by Procurement Category, 1967 .......... 124

23. Percent Sales of Bay Area Electronics Firms to Major Markets, 1961 and 1965 ........ 126

24. Percentage of Sales to Major Markets by 45 Bay Area Industries, by Size, 1955, 1960 and 19605.129

25. Number of Companies and 1969 Reported Employment of SIC Groups Surveyed to Equivalent Bay Area Totals for 1955, 1960, and 1965 ....... 132

26. Estimated Number of Employees Supported by Major Market Sales of Surveyed Industrial Firms by SIC Industry Group, as a Percent of Total Surveyed Employment, for 1955, 1960 and 1965 . . . . 133

27. Percentage of Total Bay Area Military Contracts Received by Selected Industries: 1960, 1962, and 1964 ....................... 137

28. Top Ten Bay Area Defense-Space Prime Contractors: FY 1963 and FY 1964 .............. 140

29. Defense-oriented Shipments from California and the Bay Area, 1963 . . . . . . . . . 144

30. Combined Location Quotients for Ordnance, Electrical Machinery, and Instruments in the San Jose SMSA and the Bay Area, 1960-1965 . . . . 149

31. MuItiplier Effect on Exogenous Wages and Salaries Derived from Defense-Related Spending in the Bay Area, Selected Years 


\section{LIST OF ILLUSTRATIONS}

F1gure

Page

1. Growth in San Francisco Bay Area Manufacturing Industries, 1939-1950, by Industrial Group

Employment (Percent Increase Indicated) . . . 32

2. California and San Francisco Bay Area Employment Trends, by Major Industry Groups, 1939-1950 . . 35 


\section{INTRODUCTION}

In recent years California has been accused of being economically dependent upon national military and space spending. Although the state's economy is highly diversified, an element of truth is carried in this allegation. Since the beginning of the Cold War, perhaps earlier, the economic growth of the gold rush state has certainly owed much to the United States defense program. Before the outbreak of World War Two, defense spending was a relatively small part of federal-state relationships. Federal programs were designed to overcome natural environmental obstacles, such as that presented in the Colorado River flood tineat, and to assist in the establishment of "resource-based industries." However, the federal government's increasing involvement in the economy since the 1930's and specifically after World War Two has led to new flelds of relationships, notably national defense. ${ }^{1}$ Eugene $C$. Lee, a prominent California political scientist, suggested that,".. In 1965, half of the Jobs in California were related, directly or indirectly, to defense and space activities." One

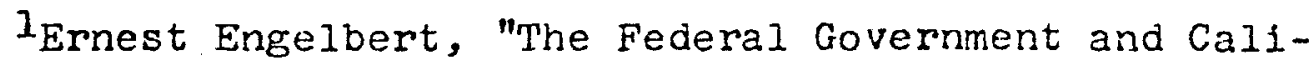
fornia's Growth," in The Callfornia Governmental Process: Problems and Issues, ed. by Eugene C. Lee (Boston: Littie, Brown \& (0., 1966), p. 29. 
million Californians or more, he continued, were employees of the federal government or one of its contractors. ${ }^{2}$ If this is a valid observation, and it appears to be, then it would seem also that the ramfications of such a large dependency upon defense and related programs merit serious study.

It would be risky, perhaps foolhardy, for this writer to attempt to make a thorough study of all the ramifications of California's alleged economic dependency upor defense and related spending. The literature dealing with this very problem is surprisingly vcluminous, and it leads In many directions through the flelds of psychology, sociology, economics, philosophy, political science, and history. Yet the many studies which have so bravely wrestled with the development and effects of this new phenomenon, often labeled the "military-industrial complex," have either been extremely broad and incomplete or confiningly specific and minute. An adequate history of the development of this leviathan and its subsequent impact on society is still unwritten. Therefore, it is hoped that this work may pave the way to such a history, although it is not intended to fill the void itself.

It is the ultimate contention of this writer that the economic dependency of an area upon military-related

2Ib1d., p. 28, editor's comments. 
programs $w 11$ be reflected in the political attitudes of the community as well as in economic impact. Before the political and phllosophical aspects may be explored, however, one must show obviously that an area is dependent upon defense expenditures. It is to this preliminary thesis that this paper is devoted, for without this foundation further work in the political history of defense expenditures would be incomplete. 


\section{THE WAR PERIOD}

California's growth as a defense contracting area has a relatively short history. Prior to World War Two her economy was most heavily based on agricultural and related pursuits, and even today agriculture remains a most important asset. However, in 1940, California began an economic transformation resulting primarly from the outbreak of global conflict. Durlng the next half-decade, her economic gains were based largely on the demands of the war, and war and related industries accounted for almost all expansion in manufacturing. While agriculture and food processing pursuits continued to expand, major manuracturIng incustries invaded California on a large scale. California's harbors became great embarkation centers and shipbuilding sites, and her southern metropolitan areas became a national center for aircraft construction. Indeed, the war greatiy augmented the "human and economic resources" of the state, expanding infant 1ncustries as well as bringing new ones and adding large numbers of people to her population. ${ }^{1}$ Furthermore, the federal governirent, particularly

ICalifornia, State Reconstruction and Reemployment Commission, Report and Recommendations for the Period Ending December 31, 1944 (Sacramento, 194j), p. I1 (Hereinafter refierred to as Report. 1944 ). 
Its military department, became the leading single investor In the state, and California became third in the list of states receiving defense contracts. The birth of a defenseorlented region was occurring during these war years, for, unlike earlier war periods, national defense spending was not to return to a pittance during the postwar years. Furthermore, a decline in conventional ordnance and automotive products as a large part of postwar defense buying was caused by a gradual rise in the importance of electronics, aircraft, and missiles. The result was a shifting of defense contracts from the older manufacturing firms in eastern states to newer firms in the rejurenated New England states and the recently industrialized states of California, Texas, and Washington. 2

California was experiencing her first "real" industrial boom; and though wartime industrial expansion may have only "accelerated a long-term trend" that would have led to the expansion eventually, the type of growth it brought might never have occurred without the war. 3 "The vast

2Merton J. Peck and Frederic M. Scherer, The Weapons Acquisition Process: An Economic Analysis (Boston: Harvard University Press, 1962), pp. 110-12. For California's relative position as a defense contracting state during World War II, Korea, and fiscal 1959-60, see infra., Table A, Appendix I, p. 189. For estimated government security expenditures in relation to the GNP, 1939-52, and trends of U.S. post-war defense spending after major wars, see infra., Tables B and C, Appendix I, pp. 190 and 191 .

3Carey Mchilliams, California: The Great Excention 
expenditures of the National Government for these war materials," observed the State Chamber of Commerce in 1ts Economic Survey for 1942, "are the controlling factor. The present war production program is revolutionizing the Industrial economy of the State." 4 In addition to the aircraft and shipbuilding boom, military expenditures expanded Industries dealing with nonferious metals and products, electrical machinery and products, other machinery, iron and steel products, rubber, chemicals, and petroleum. 5 Larger plants tended to force the smallest companies to disband, as an increase of 46 percent occurred in the number of companies employing from 10 to 200 persons. 6 For unlike most other war production areas, California did not convert peacetime industries to war production. Indead, there were few to convert. Therefore, new industries were built overnight, gearing themselves solely to wartime needs.7

(New York: A. A. Wyn, Publisher, 1949), pp. 233-34, agrees in part with this analysis.

${ }^{4}$ California, State Chamber of Commerce, "Economic Survey of California and Its Counties," in California Bluebook, 1942 (Sacramento, 1942), p. 338 (Hereinafter referred to as BIuebook, 1942).

5Maurice I. Gershenson, "Wartime and Postwar Employment Trends in California," Monthly Labor Review, LXIV (Apri1, 1947), p. 578. See also the employment figures in, infra., Table A, Appendix II, p. 195.

6 Report, 1944, p. 18.

7 McWliliams, California, pp. 233-34. 
During the course of the war, the federal government invested $\$ 150$ milion in aircraft production facilities, $\$ 409$ million plus for shipbuilding facilities, $\$ 117$ million for Iron and steel production facilities, and many more millians for other industrial and military facllities. Private investments trailed far behind the government's in these three major industries, totaling only $\$ 141$ million; 8 and, while this was not unusual in many states during the war, it was indeed unique for California. Table 1 gives some indication of government wartime outlays in the state during the flrst years of the war. The two major areas receiving the bulk of these vast expenditures and those that followed through 1946 were the Los Angeles-San Diego and the San Francisco Bay areas, the latter, of course, being the topic of this work.

Industrial growth brought with it a rush of people to California which, according to Carey McWilliams, ". . produced an impact not unlike that of the gold rush." Indeed, it was greater since the wartime migrants flooded the already crowded metropolitan areas. ${ }^{9}$ Coupled with a wartime

${ }^{8}$ California, State Chamber of Commerce, "Economic Survey of California and Its Counties," in California Bluebook, 1946 (Sacramento, 1946), pp. 437-39 (Hereinaiter referred to as Bluebook, 1946).

9McWilitams, California, pp. 12-14. The first chapter of this work contains a particularly good though brief analysis of California's wartime population growth. 
TABLE 1

MAJOR WAR SUPPLY AND FACILITY CONTRACTS AND ALLOCATIONS, 1 JUNE, 1940 - I JUNE, 1942

\begin{tabular}{|c|c|c|c|}
\hline & California & $\begin{array}{l}\% \text { US } \\
\text { Total }\end{array}$ & US Total \\
\hline 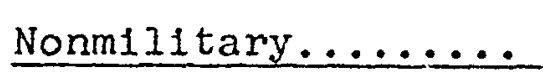 & $\$ 186,427,000$ & 6.65 & $\$ 2,822,296,000$ \\
\hline Military........... & $6,757,692,000$ & 8.72 & $77,516,392,000$ \\
\hline Supply Contracts.. & $5,407,263,000$ & 9.76 & $55,417,328,000$ \\
\hline Alrcraft \& Parts & $3,590,826,000$ & 18.35 & $19,571,842,000$ \\
\hline & $1,509,094,000$ & 16.35 & $9,232,176,000$ \\
\hline supplies..... & $307,343,000$ & 1.15 & $26,613,310,000$ \\
\hline Facilities Projects & $1,350,429,000$ & 6.11 & $22,099,064,000$ \\
\hline $\begin{array}{l}\text { Industrial Plants } \\
\text { Milftary Facili- }\end{array}$ & $607,741,000$ & 4.44 & $13,700,358,000$ \\
\hline $\begin{array}{r}\text { ties..... } \\
\text { te }\end{array}$ & $742,688,000$ & 8.84 & $8,398,706,000$ \\
\hline otal & $6,944,199,000$ & 8.64 & $80,338,688,000$ \\
\hline
\end{tabular}

Source: California, State Chamber of Commerce, "Economic Survey of California and Its Counties," in California Bluebook, 1942 (Sacramento, 1942), p. 340 .

birth increase, the growing population had a profound impact on California. The San Francisco area, for example, almost doubled its population during the war years (Table 2). And, as Table 2 indicates, the growth did not stop after the war's end. The California State Reconstruction and Reemployment Commission explained that the postwar departure of war workers and their families was offset by ". . . many 
TABLE 2

SAN FRANCISCO BAY AREA WARTIME POPULATION INCREASE

\begin{tabular}{|c|c|c|c|}
\hline County & 1940 & 1946 & 1950 \\
\hline 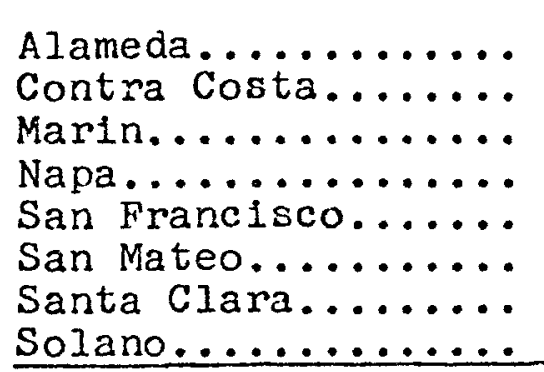 & $\begin{array}{r}513,011 \\
100,450 \\
52,907 \\
28,503 \\
634,536 \\
111,782 \\
174,949 \\
49,118 \\
\end{array}$ & $\begin{array}{r}743,000 \\
257,000 \\
76,200 \\
42,700 \\
800,000 \\
183,000 \\
229,000 \\
127,000 \\
\end{array}$ & $\begin{array}{r}734,740 \\
297,400 \\
84,739 \\
46,373 \\
760,381 \\
234,030 \\
288,852 \\
102,194 \\
\end{array}$ \\
\hline 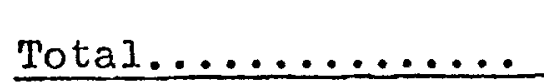 & $1,665,256$ & $2,457,900$ & $2,548,709$ \\
\hline State & $6,950,000$ & $9.559,000$ & $10,643,000$ \\
\hline
\end{tabular}

Source: California, State Chamber of Commerce, Economic Survey of California and Its Counties," in California Bluebook, 1942 (Sacramento, 1942), pp. 360, 392, 467, 504, 570, 591, 603, and 527; ibid. (1945 edition), pp. 468, 496, 576, 604, $676,696,708$, and 728; and 1bid. (1350 edition), pp. $816,834,898,920,980,1000,1010$, and 1028.

thousands of servicemen, pre-war residents of other states, who decided to live in California after release from the armed forces."10 A]so, as government defense contracts continued to find their way to the state, the more highly trained and educated worker was encouraged to come to California and combine his research taients and intellectual

$10_{\mathrm{Cal}}$ ifornia, State Reconstruction and Reemployment Commission, Report of the State Reconstruction and Peemoloyment Commisston for the Period from August, 1943 through December, 1945 and for the Year 1946 (Sacramento, 1947 ), p. 13 (Hereinafter referred to as Report, 1946). 
interests with a Mediterranean climate. 11 Thus, from 1940 to 1950, the state's population grew from 6,907,387 to $10,586,233.12$ (Table 3 gives annual growth figures.)

TABLE 3

APPROXIMATE ESTIMATES OF NATURAL INCREASE AND NET MIGRATION INTO CALIFORNIA BY YEARS, 1940 - 1949

Increase over year before

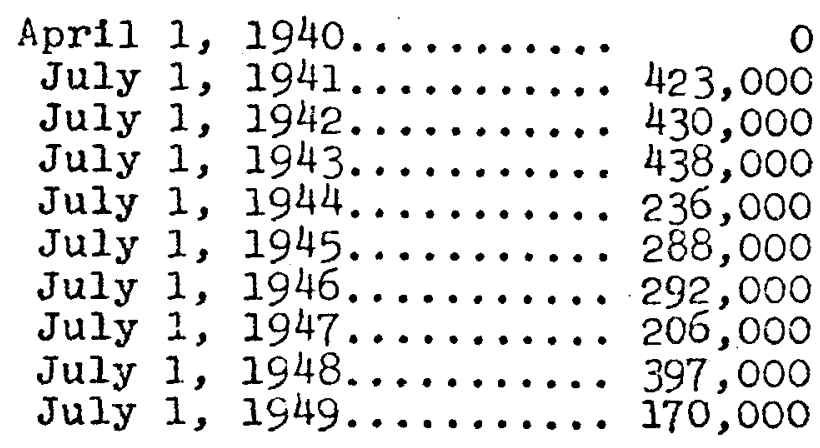

Source: California, Department of Employment, Proceedings of tre Governor's Cont'erence on Employment, December 5-6, 1949 (Sacramento, 1950), p. 244.

As a part of the population and industrial growth, all sections of Californla's society and economy were

11Eugene Burdick, "From Gold Rush to Sun Rush," in The California Governmental Process: Problems and Issues, ed. by Eugene C. Lee (Boston: Little, Bruwn, \& Co., 1966), p. 244 .

12Bluebook, 1942, p. 336; and California, state Chamber of Commerce, "Economic Survey of Calliornia and Its Counties," in California Biuebouk, 1950 (Sacramento, 1950), p. 765 (Hereinafter rererred to as Bluebook, 1950). 
stimulated. Over 100,000 new permanent private fam1ly dwellings and some 21,000 new permanent public housing units were constructed during the war years. 13 The number of government employees increased twofold in the five years after 1940, as communities expanded their public services. 14 While the number of manufacturing establishments increased from about 12,000 in 1939 to 18,000 in 1947, wholesale trade firms increased from 14,000 to 18,000 and retail trade firms grew from 112,000 to 120,000 . Even more significantly, total wholesale and retall trade sales increased $\$ 9$ billion and $\$ 7.5$ billion respectively from 1940 to 1948.15 Perhaps the war's economic impact can be best illustrated by the growth in employment illustrated in infra., Chart 1, p. 32, and Table A, Appendix II, which shows California's total Growth experience.

The San Francisco Bay Area ${ }^{16}$ naturaily shared in the state-wide economic transformation, as can be seen in the
13 Report, 1944, p. 19.
14 Bluebook, 1946, p. 422.
15Bluebook, 1942, p. 358; and Bluebook, 1950, p. 806.
16 For the purposes of this work the San Francisco Bay Area includes Alameda, Contra Costa, Marin, San Francisco, San Mateo, Santa Clara, and Solano Counties. Sonoma and Napa Counties have generally been excludea, as statistical information for them is not readily available. Another county grouping citen used by sources cited in this work and sometimes used herein is the San Francisco Industrial Area, composed of Alameda, Contra Costa, Marin, San Francisco, and San Mateo Counties. 
wage and employment trends illustrated in Table $D$, Appendix II, and Infra, Chart 2, p. 36. The area became the embarkation center for the war effort in the Pacific, with more than 30,000 military personnel assigned in the region at the war's peak. 17 Tremendous port facilities were needed for such a center, and federal funds were poured into the construction of these. The result was the development and expansion of facilities such as Mare Island Naval Yard, Solano County, with more than 20,000 civilian employees; the U.S. Naval Air Station, Alameda; the U.S. Naval Supply Depot, Oakland; Fort Mason, the center of San Francisco's embarkation effort; the U.S. Army Embarkation Base, Oakland; the 800th U.S. Army Air Force Depot, Alameda; FalrfieldSuisun Alr Force Base, Solano County; the U.S. Naval Air Station, hoffett Field, in Sunnyvale; and many other military installations. 18 Additionally, millions of dollars came into the area in the form of supply contracts and through the construction of industrial facilities. In San Jose, by June, $1942, \$ 8,496,000$ was invested by the government in new plants for magnesium, ferro-silicon, and plastics production.

17 James $W$. Hamilton and William J. Bolce, Gateway to Victory (Stanford: Stanford University Press, 1946), p. 193.

18Bluebook, 1942, p. 627; Bluebook, 1946, p. 467; and Bluebook, 1950, p. 2026. See also, Heliler Goodin Scott, The San Prancisco Bay Area: A Metropolis in Perspective (Berkeley: University of Calffornia Press, 1959), pp. $245-45$. 
An additional $\$ 31,370,000$ was also given the San Jose area In contracts, while Napa County recelved $\$ 460,692,000$ in defense contracts during the same period. obviously, the investment for the total war period was much greater, as lllustrated by Alameda County's experience in recelving $\$ 59,379,000$ for industrial facilities and $\$ 909,628,000$ in supply contracts. 19 Yet the first years of the war brought the most significant impact and began the transformation of the economy. Overall, the San Francisco Industrial Area, plus Solano County, received $\$ 738,368,000$ in primary defense contracts by September 21, 1941, not quite onefourth of the total contracts for the war period. (See Table 4.)

By June, 1945, the Bay Area had received a total of $\$ 3,053,119,000$ in shipbullding contracts alone--59.2 percent of the total awarded to the state. 20 The impact of such contracts was enormous. The Richmond shipyards of the ToddCalifornia Shipbuilding Corporation (owned by Henry J. Kaiser), for example, had constructed 563 Liberty-type cargo vessels between January, 1941 and mid-1944--a task requiring thousands of workers, millions of dollars, and involving many other industries. 21 It has been estimated that, of an

19B1uebook, 1942, pp. 572, 604, and 606-507; and Bluebook, 1946, p. 460 . 20 Bluebook, 1946, p. 438 21 Joseph C. Whitnah, A History of Richmond, California 
TABLE 4

VALUE OF U.S. GOVERNMENT CLEARED PRIMARY DEFENSE CONTRACTS AWARDED TO SAN FRANCISCO BAY AREA FIRMS TO SEPTEMBER 21, 1941, BY INDUSTRY-GROUPS

\begin{tabular}{|c|c|c|}
\hline Industry-Groups & $\begin{array}{l}\text { Value } \\
\text { (In thousands) } \\
\end{array}$ & \% of Total \\
\hline 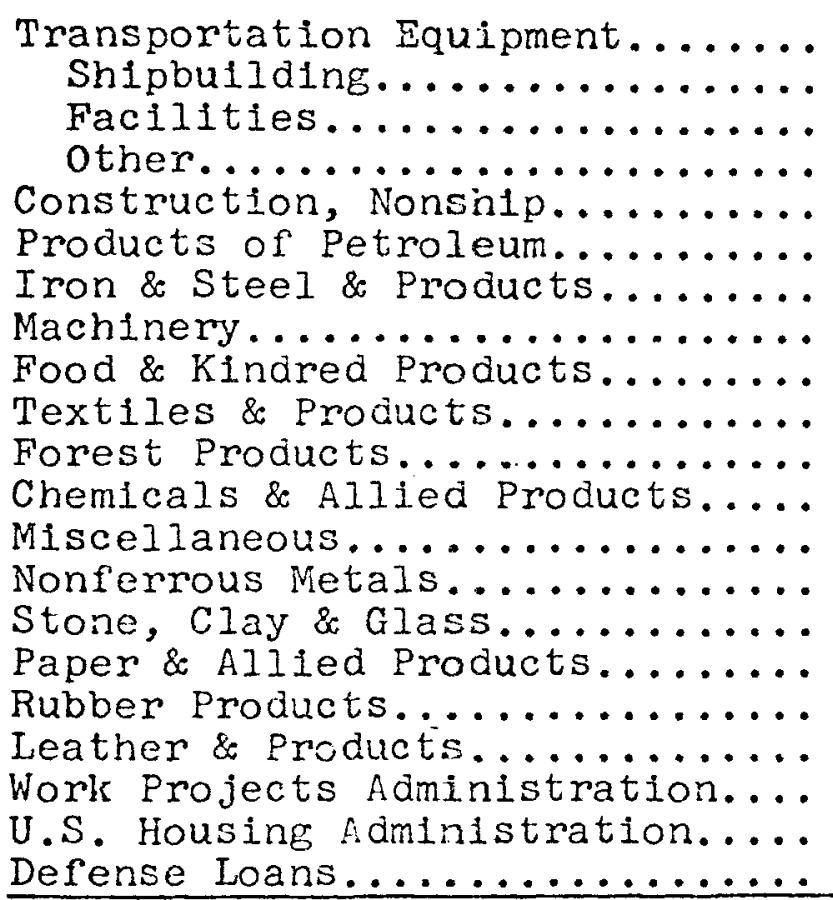 & $\begin{array}{r}\$ 668,808 \\
629,178 \\
39,618 \\
12 \\
17,669 \\
11,261 \\
7,838 \\
3,020 \\
1,628 \\
1,148 \\
606 \\
603 \\
423 \\
90 \\
89 \\
36 \\
35 \\
4 \\
6,282 \\
2,400 \\
15,428 \\
\end{array}$ & $\begin{array}{r}90.5 \\
85.1 \\
5.4 \\
-.- \\
2.4 \\
1.5 \\
1.1 \\
.4 \\
.2 \\
.2 \\
.1 \\
.1 \\
.1 \\
-.- \\
--- \\
-.- \\
-.- \\
--- \\
.9 \\
.3 \\
2.2\end{array}$ \\
\hline lova 1 & 738,368 & 100.0 \\
\hline
\end{tabular}

Source: California, State Planning Board, An Economic and Industrial Survey of the San Francisco Bay Area, by Robert DeBois Calkins and valter E. Hoadly, Jr. (Sacramento, 1941), p. 226.

average of more than 75 industries sharing each shipbuliding contract, a majority of these subcontracts went to Bay Area flrms. Thus, between June I, 1940 and January 31, 1941, an

(Richmond, California: Richmond Chamber of Commerce, 1944), pp. 119-20. 
average of 59 percent of payments by Bay Area prime contractors to subcontractors went to firms in the region. 22

Shipbuilding led the new and expanded industries in the Bay Area, growing from almost an idle industry of three plants to the largest in the area, consisting of twelve companies. As an example of the impact of this growth on employment, consider that Contra Costa County had 361 shipyard workers in January, 1941, whereas, in December, it had $17,880.23$ Following the shipbuilding industry, which was the leader in both employment and wages paid in 1944, were the machinery industries. Though slightly trailing the combined industries of chemicals, petroleum, coal, and rubber in wages paid-- $\$ 73,291,000$ compared to $\$ 73,510,000--$ the machinery industries were clearly second in employment growth. The chemicals, petroleum, coal, and rubber industries ran a close third. These were followed by the growth In ferrous and nonferrous metals and products, the latter's growth being much assisted by the expansion of the Columbia Steel Company plant in response to demands of the shipyards.

22California, State Planning Board, An Economic and Industrial Survey of the San Francisco Bay Area, by Robert DeBois Calkins and Walter E. Hoadly, Jr. (Sacramento, 1941), pp. 24l-43 (Hereinafter referred to as Calkins and Hoadiy, Survey).

23California, Department of Employment, Research and Statistics Division, California Employment and Payrolis in 1941: A Study of Workers (and Wages) Covered by the Callfornla Unemployment Insurance Act. Ciassified by Industry and by Count, Rept. No. 127, Pt. 4(Sacramento, undated), pp. 1314 (Herelnafter referred to as Employment and Payrolis in [appropriate date], [rept. and pt. designation]). 
And ordnance and instruments also developed slightly. In addition to these military-related industries, one of the chief beneficiaries of the war effort was the construction industry. In Richmond, for example, $\$ 35$ million had been spent for 21,843 dwelling units by the end of 1944, and similar amounts were spent throughout the Bay Area. Furthermore, the food industry showed some growth, as government contracts for foodstuffs served to ofiset the industry's wartime loss of foreign trade. Finally, among other industries receiving primary effects of defense spending were those dealing with apparel, furniture, and paper and allied products. Table D, Appendix II, 1llustrates the overall growth in wages pald, whereas Table 5 indicates the growth in terms of employment. 24

The secondary effects of the defense effort were equally as important as the primary in the Bay Area's economic transformation. From 1939 to 1944 payrolis grew 68.3 percent and the number of wage-earners increased 41.5 percent. 25 In December, 1940, the business index of the San Francisco Chamber of Commerce was at the highest level on record, except for a short time in 1929, 167 percent of its 1923-1925 average; and, in October, 1941, the Index was

\footnotetext{
24 Infra, Table B, Appendix II, p. 195; Calkins and Hoadly, Survey, pp. 230-41; and Whitnah, Richmond, pp. 124-25. ${ }^{25}$ Calculated from, infra, Tables $B$ and $D$, Appendix II, pp. 196 and 198 .
} 
TABLE 5

EMPLOYMENT TRENDS IN MILITARY-RELATED MANUFACTURING IN THE SAN FRANCISCO BAY AREA ${ }^{2}$

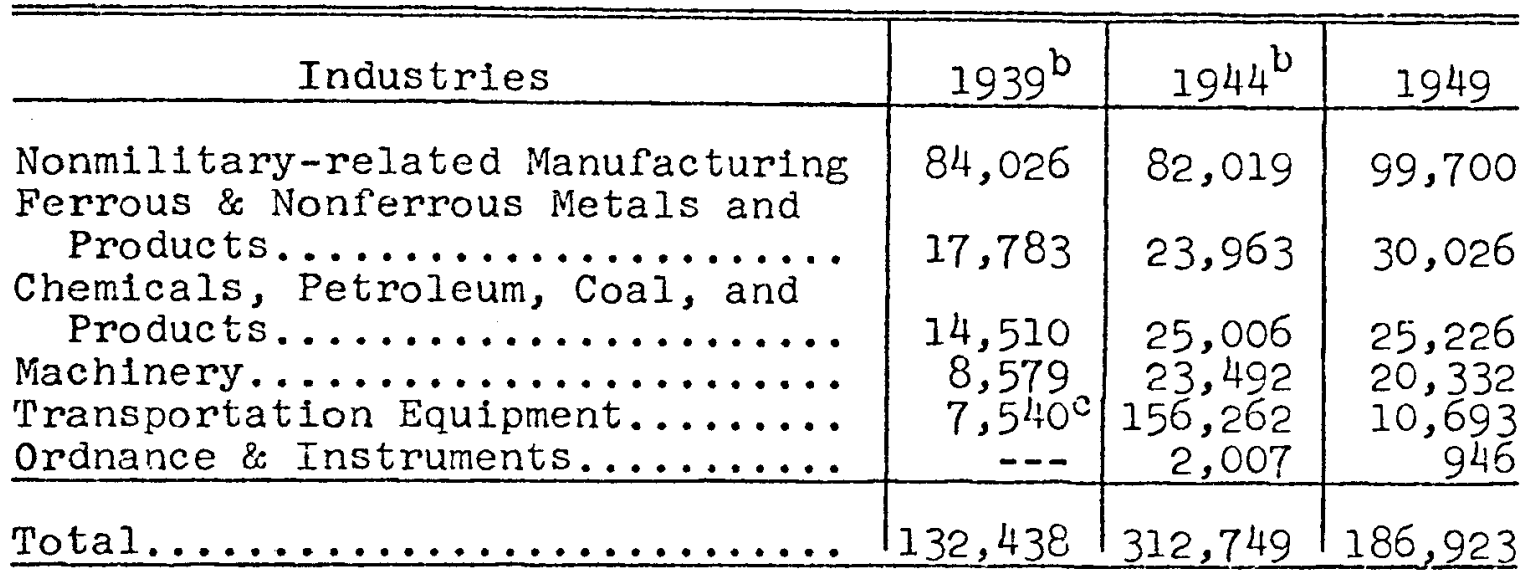

${ }^{a} \mathrm{Ca}$ lculated from, Californla, Department of Employment, Research and Statistics Division, Califormia Employment and Payrolls in 1939: A Study of Workers (and Wages) Covered by the California Unemployment Insurance Act. Clessified by Industry and by County, Rept. No. 127, Pt. 2 (Sacramento, August, 1941), and Pts. 7 and 12 for the years 1944 and 1949.

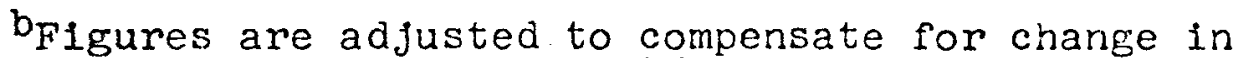
insured employment coverage in 1946, from only firms employing four or more workers to firms employing one or more workers. Percent increase for each industry and original figures used in adjustment are in Tables $A$ and $B$, Appendix II.

used.

CData for 1939 unavallable, therefore 1940 data is

steady at 152. Roughiy $\$ 200$ per capita was added to San Francisco Industrial Area plus Solano County when, between June I, 1940 and January 31, 1941, \$268.3 milion of \$444.5 million in contracts awarded to Bay Area firms were expended there. Despite tax increases and aligmented cost of living standards during the period, the net rise of purchasing power was great among all segments of the community and 
helped to increase employment in other fields. 26 While Table $D$, Appendix II, gives an indication of growth through wages pald, Table 6 illustrates the growth of major nonmanufacturing and nonconstruction industry groups through employment figures. Indeed, the wartime growth of the Bay Area was almost phenomenal. Th1s, however, was merely the beginning, for the growth was not to end with the war.

TABLE 6

NONMANUFACTURING AND NONCONSTRUCTION INSURED EMPLOYMENT GROWTH IN THE SAN FRANCISCO BAY AREA ${ }^{a}$

\begin{tabular}{c|r|r|r|r}
\hline Industries & 1940 & 1943 & 1946 & $\%$ change \\
\hline $\begin{array}{c}\text { Transportation, Commu- } \\
\text { nication, \& Utilities }\end{array}$ & 44,697 & 59,078 & 69,651 & +35.4 \\
Wholesale \& Reta1. & & & \\
Trade............ & 113,829 & 166,236 & 200,796 & +43.3 \\
Finance, Insurance \& & & & \\
Real Estate........ & 28,624 & 36,425 & 43,742 & +34.5 \\
Service Industries..... & 81,372 & 52,731 & 83,414 & +2.4 \\
Governmentb........... & 51,500 & 111,400 & 121,600 & +57.6 \\
\hline
\end{tabular}

Exxcludes Marin and Solano Counties, except for "Government," which includes Marin and excludes Santa Clara and Solano Counties. Data for 1940 and 1943 is adjusted (see Table 5, n.b). Calculated from, California, State Chamber of Commerce, "Economic Survey of California and Its Counties," In California Bluebook, 1946 (Sacramento, 1946), p. 688; California, Department of Employment, Research and Statistics Division, Callfornia Employment and Payrolls in 1940: A study of Workers (and wages) Covered by the California Unemployment Insurance Act. Classifled by Incustry and by County, Rept. No. 127, Pt. 3, (Sacramento, November, 1942), and Pts. 5, 6, and 9 for the years 1943 ard 1946.

bData is not adjusted for 1940 and 1943, does not include only insured employment, and appears to be only approximate.

26 Calkins and Hoadly, Survey, pp. 241-51. 


\section{THE POSTWAR PERIOD}

Unlike other postwar periods in American history, the events of the years immediately following World War Two prompted United States leaders to continue defense programs on a large scale. As noted in Table C, Appendix I, expenditures directed toward the military, veterans, and interest on the national debt--the latter owing 1ts existence primarily to war-related borrowing--made up 59.8 percent of government expenditures between 1946 and 1949. On a per capita basis, as shown in Table 7 , the average militaryrelated spending was approximately 60.5 percent of total government spending, from 1947 through 1950--33.9 percent greater than the percentage of military-related spending as a part of total government spending in 1939.

The tension throughout the world, which seemed to increase at an ever-quickening pace after V-J Day (August 14, 1945), understandably guided the nation's defense spending policies. With the memory of the lost peace of Versaliles In mind and the rather sudden outbreak of the Cold War occurring, America's leaders refused to withdraw from the world's problems. Instead, they prepared to keep the peace, through force of arms if necessary. On March 12, 1947, President Truman requested Congress to support military and 
TABIE 7

FEDERAL EXPENDITURES, PER CAPITA, IN 1926 PRICES, 1939-1952

\begin{tabular}{|c|c|c|c|c|c|c|c|c|}
\hline Year & Miiftary & $\begin{array}{c}\mathrm{B} \\
\text { Veterans }\end{array}$ & Interest & Total & $\begin{array}{l}\bar{A}, \bar{B}, \mathrm{C} \\
\mathrm{COI} \cdot \mathrm{D}\end{array}$ & Forelgn & C1vil & Total \\
\hline 1939 & $\$ 10.56$ & $\$ 6.10$ & $\$ 8.05$ & $\$ 24.81$ & 25.6 & $\$ .1 .9$ & $\$ 68.03$ & $\$ 93.03$ \\
\hline 1940 & 14.49 & 6.10 & 8.45 & 29.04 & 31.2 & .48 & 63.04 & 92.92 \\
\hline 1941 & 59.11 & 5.65 & 8.28 & 73.04 & 56.2 & 1.31 & 55.55 & 129.90 \\
\hline 1942 & 210.48 & 4.47 & 7.68 & 222.61 & 82.3 & 4.96 & 42.90 & 270.49 \\
\hline 1943 & 506.36 & 4.14 & 10.23 & 510.73 & 89.8 & 1.20 & 46.70 & 568.63 \\
\hline 1944 & 585.39 & 4.48 & 14.45 & 604.32 & 92.0 & 1.71 & 50.57 & 656.60 \\
\hline 1945 & 576.12 & 7.45 & 19.22 & 602.79 & 92.9 & 4.61 & 41.03 & 648.43 \\
\hline 1946 & 295.83 & 21.33 & 24.36 & 341.52 & 84.3 & 9.58 & 53.56 & 404.66 \\
\hline 1947 & 62.09 & 33.18 & 18.97 & 114.24 & 62.9 & 31.03 & 36.20 & 181.47 \\
\hline 1948 & 51.66 & 28.95 & 16.46 & 97.07 & 62.4 & 24.53 & 33.70 & 155.30 \\
\hline 1949 & 50.00 & 28.88 & 16.10 & 94.98 & 56.5 & 27.48 & 45.47 & 167.93 \\
\hline 1950 & 53.39 & 39.85 & 18.62 & 111.86 & 50.2 & 20.26 & 53.60 & 185.72 \\
\hline 1951 & 75.95 & 22.07 & 15.25 & 113.27 & 67.1 & 16.33 & 39.11 & 168.71 \\
\hline 1952 & 143.03 & 20.69 & 14.87 & 178.59 & 73.1 & 20.41 & 45.29 & 244.29 \\
\hline
\end{tabular}

Source: Calculated from, M. Slade Kendrick, "A Century and a Half of Federal Expenditures," Occasional Paper 48' (Rcvised) (New York: National Bureau of Economic Research, Inc., Iy55), pp. 84-86. 
economic aid for Turkey and Greece in opposition to Communist pressures, a request which was soon fulf:lled. ShortIy afterwards, at Harvard University on June 5, 1947, George C. Marshall (later President Truman's Secretary of Defense) called for a program to assist western European countries in gaining economic recovery from the war. In April, 1948, the Berlin Airlift more deeply comitted America to the Cold War. Then, two years later, the United States found herself involved once again in an actual war, following the Communist Invasion. of South Korea, on June 25, $1950 .{ }^{1}$

Steady defense spending, in response to international tensions, was to become national policy; and it would coninue to affect the California economy and society. At the close of the war, suggested Eugene Burdj.ck, the Californta economy was ". . Impossibly out of balance. . - [However,] it was saved by the cold war. . . Today [1963] Californla gets more defense contracts than any other single state."2 This observation is probably correct; for the California electronics, communications equipment, aircraft, and space industries obvlously benefited from continued government defense contracting.

The resurgence of vast military-related research

$1_{M}$. Slade Kendrick, "A Century and a Half of Federal Expenditures," Occasional Daper 48 (Revised) (New York: National Bureau of Economic Research, Inc., 1955), p. 52. 2Burdick, "Gold Rush," p. 5. 
and development ( $R \& D$ ) by private industry and private institutions was particularly significant. Immediately after the war the federal office of Scientific Research and Development was disbanded, military research (except in atomic energy) reverting almost exclusively to the services. $A$ joint $R$ \& $D$ board coordinated military-related research, but it initiated few new programs. However, the creation of the National Defense Establishment under the 1947 National Security Act prompted new research. The birth of inter-service competition for financial resources with the A1r Force-Navy conflict over supremacy for a long-range strategic bombing or for an aircraft carrier oriented defense policy added to the growth of $R \& D .3$ obviously, large amounts of federal funds were going to be invested In new defense policies, whatever the policies were to be. California's war-born and war-nurtured aircraft, electronics, and tiny scientific instrument industries were tailor-made for such government expenditures; moreover, her research institutions, particularly the California Institute of Technology, were already receiving $R \& D$ contracts. 4

3 Peck and Scherer, Weapons Acquisition, pp. $70-77$. See also, Werner Z. Hirsch and Richard N. Baisden (eds.), California's Future Economic Growth (Berkeley: Diablo Press, 1965), p. 21 .

${ }^{4}$ Alfred D. Chandler, "Development, Diversification, and Decentralization," in Postwar Economic Trends in the United States, ed. by Ralph E. Freeman (New York: Fiarper \& Brothers, Pubishers, 1960), pp. 237-38, suggests that, since 
Carey MicWiliams suggested that this institution recelved more than $\$ 80$ million in contracts during the war years and, furthermore, that this amount was just the beginning of even greater postwar contract awards. 5 In any event, California Institute of Technology carried out considerable government $R \& D$. Also responding to the technological revolution and demands for research facllities, Stanford University established the Stanford Research Institute in November, 1946, appointing as its director Dr. William F. Talbot, president and technical director of Fine Chemicals Division of the Sun Chemical Corporation. Soon afterwards the State Reconstruction and Reemployment Commission recommended that a ". . nonprofit research organization to be known as the Pacific Research Foundation be established in California, functioning in full cooperation with western universities, sharing research programs and supplementing their facilities." The Commission also recommended that the Foundation undertake projects sponsored by individual companies; groups of companies; and federal, state, and local governmental agencies. 6 Hence California responded to the postwar growth

Worid War Two, these three industries have been dependent on government spending in excess of 50 percent, particularly in $\mathrm{R} \& \mathrm{D}$. He also lists, as somewhat dependent on government spending, the automobile, power machinery, chemicals, petroleum, and rubber industries.

5 McWilliams, California, p. 262. 6 Report, 1946 , pp. $46-48$. 


$$
24
$$

of technology and perhaps as well to the continued presence of federal defense $R$ \& $D$ contract awards.

Clearly, government contracts were desirable to the war-born Californla manufacturing industries, for the close of the war promised to bring economic problems to the state. In 1944 war production began to decline, and employment in manufacturing dropped 76,712 throughout the state and 18,618 In the San Francisco Bay Area.7 This 1944 decline was less than serious, as it primarily involved the withdrawal of women war workers from the labor market. 8 However, declines in 7945 had a definite detrimental impact upon California and Bay Area employment. War expansion had mainly occurred in the aircraft and shipbuilding industries, and in 1943 and 1944 one-half of the manufacturing employment trroughout the state and the Bay Area was accounted for by these industries. 9 Therefore, the rapid decline of war contracts to these industries after V-J Day had a substantial effect on employment. Between 1945 and 1946, the cessation of military contracts coupled with a work stoppage of machinists and shipyard workers from November, 1945 to March, 1946 caused an average yearly employment drop in the Bay Area's

TInfra, Tables A and $\mathrm{B}$, Appendix II, pp. 195 and 196. 8 Employment and Payrolls in 1944, Rept. No. 127 , Pt. 7 (undated), p. 2 .

9Gershenson, "Employment Trends," p. 584; and Infra, Tables A and B, Appendix II, pp. 195 and 196. 


\section{5}

transportation equipment manufacturing industries of 62,538 . Additionally, smali decreases were experienceu in machinery, metals, rubber, chemicals, and petroleum manufacturing employment--although these are not clearly reflected in the average yeariy totals. Finally, the cancellation of military fac1lity construction contracts resulted in a 1945 construction employment loss of 2,834 jobs over the previous year's average. 10

Four months after V-J Day, Californla began what the Department of Employment termed ". . . one of the most critical years in the history of the State."ll As noted by the state government, California did not have, after the war, a large manufacturing industry complex to reemploy its many war workers at the onset of peacetime reconversion. Some 85 percent of the employees in the shipbuilding and aircraft industries alone, it was estimated, would need new jobs; and as contract cancellations continued, a drop of 62.4 percent did occur between 1945 and 1947 in the average yearly Bay Area transportation equipment industry employment. ${ }^{12}$ The

10Employment and Payrolls in 1945, Rept. No. 127, Pt. 8 (undated), pp. 1-3; and infra, Table B, Appendix II, p. 196. Wage payments also reflect this drop as shown in infra, Table D, Appendix II, p. 198.

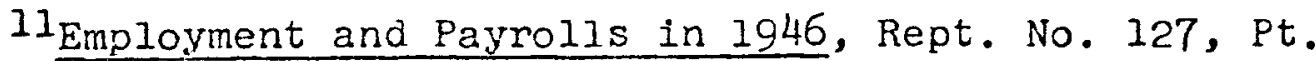
9 (undated), p. I.

12California, Reconstruction and Reemployment Commission, Report and Recommendations for the Period Ending December 31, 1945 (Sacramento, 1946), p. 21; and 1nfra, Table E, Appendix II, p. 196. 


\section{6}

loss of government contracts threatened the economic welfare of the state.

Ernest Englebert observed in 1963 that California's strong national voting power and great diversity of interest groups--even more powerful and more diverse when combined with other western states-gave the state tremendous political bargaining power. ${ }^{13}$ As the war ended in 1945 , Californla leaders appeared to recoginize this power. The State Chamber of Commerce had observed and applauded the fact, as early as 1942, that Californla was the third largest state in the volume of war contracts. Furthermore, the group suggested, if all ". . smaller contracts were included in the tabulation, California would be shown as the leading war supply producling state, as well as first in the production of alrerart and ships."14 Whitrah, in his 1944 Richmond Chamber of Commerce-sponsored history of that city, wrote that this community was ". . one of the outstanding Industrial and war production centers . . " of the West Coast. He also related that ". . It merely remained for the community and the industrial leaders..." to take advantage of the wartime economic good fortune in order to secure the future. 15 Meanwhile, the state had formed the

13 Englebert, "Californla's Growth," pp. 32-33.

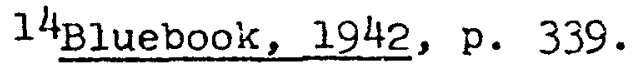

15Whitnah, Richmond, pp. 117 and 128. 
Reconstruction and Reemployment Commission to act as a ". . rallying point for industry, labor, agriculture, and government agencies . . . In planning for peacetime economic adjustments. 16 Then, in 1949, as the decade ended, the Governor's Conference on Employment vaguely hinted that employment could be stimulated by national defense spending or at least by "adding to the budget" at both the state and national levels. 17

Although the presence of political interest and influence in California toward obtaining military contracts for private industry is alluded to, one must not assume it was, during the postwar years at least, of great importance. Indeed, caution must be employed here. It is extremely easy to misinterpret statements or to extract only those phrases which will support one's case. The State Chamber of Commerce, in 1942, was obviously not advocating continued large military spending. Whitnah did not define what he meant by taking advantage of wartime gains. It is probable that he never conceived that Richmona's future industrial strength would be based on continued government contract awards, nor does this community's economic strength presentiy seem to be grounded upon such a basis. The Reconstruction and

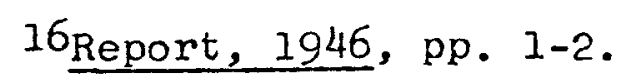

17 California, Department of Employment, Proceedings of the Governor's Conference on Employment, December 5-6, 1949 (Sacramento, 1950), pp. 221-26. 
Reemployment Commission obviously was not designed to stimulate industry and goverrment agencies in the realm of military spending, and the Governor's Conference was not furtively proposing defense spending as a cure for unemployment. In fact, government contracts existed because of national policy based largely on international issues, and not state political pressures; moreover, contracts came to California primarily because it was the core of the new technological industries. In other words, political pressures did not direct the contract flow. However, a mood was expressed in these four examples of offictal and semtofficial statements--a mood recognizing the strength of the state and the potentlal of government spending.

To explore this point further, some general observations seem relevant. A few writers, such as Englebert, believe that political influences on the defense contract flow are extremely important in determining where and to whom the awards shall go. 18 on the other hand, Peck and Scherer suggest that ". . . the direct effect of politics in the weapons acquisition process tends to be exaggerated - . The political factor [1s] so Intermixed with other

\section{Englebert, "California's Growth," pp. 32-33.} Among other spokesmen for this view are, Paul Goodman, "A Causerie at the Military Industrial," The New York Review of Books, IX (November 23, 1967), 14-19; Fred J Cook, the Warfare State (New York: The MacMilian Co., 1962), passim; and Donald A. Wells, The War Myth (New York: Pegasus, 1957), chaps. XI-XV, passim. 
issues that it is difficult to discern its importance in shaping the outcome . . " of any particular contract decision by the government. 19 In studying the contract process, Peck and Scherer were led to conclude, first,

The spoor of alleged political influence in weapons acquisition. . . is to be found everywhere. But a fair shot at the breast itself is rare. It was common, for example, to hear about claims of political influence from a losing bidder. What he did not recite was the countervailing political influence which he attempted to exert, unsuccessfully. The net of these countervalling forces appears, often, to approach zero. 20

And, secondly,

- . the sheer size of the weapons industry, its widespread dispersion throughout the country, and its crucial importance to certain regions inevitably means that changes in the weapons acquisition process have widespread economic consequences. As a result there will be at least some poiltical pressures upon weapons development and production decisions. There is simply too much at stake for weapons acquisition to be an entirely private affair between the services and their contractors.21

It would seem that this tempered judgment, so succinctly expressed by Peck and Scherer, is a most logical one. In this sense, it is important to note that state officials had some conception of California's position of strength in the nation and the power of federal spending during the war decade of the forties.

Between 1940 and 1946, labor and expenditures were

19 Peck and Scherer, Weapons Acquisition, p. 114. ${ }^{20}$ Ibid., p. $x$.

21 Ibid., p. 107. 
channeled 1nto war industries. Whereas the growth in service and, to some extent, trade industries responded less to increasing population. 22 Service and trade industries fell off considerably between 1939 and 1940. While the latter partially revived, both tended to malntain relatively stable employment until 1945. After 1944 their growth rate quickened until 1948, leaving trade above the 1939 average and service about even. War industries and construction, on the other hand, grew considerably between 1940 and 1944, and whlle war-related industries fell off quickly at the war's end, their employment and wages nonetheless remained conslderably higher than the 1939 average. Employment ir the chemicals, petroleum and coal, rubber, metals, and machinery industries was 40,872 in 1939. In 1944 it was 71,548 ; and, in 1949, adding 946 workers in the small instruments industry, it stood at 75,584 . Thus an overall percentage increase of 42.8 occurred between 1939 and 1949. Simllarly, wages paid in these industries in 1949, including instruments, stood at $\$ 273,618,000$. This figure was in contrast to $\$ 71,130,000$ in 1939 , and it represented an increase of 73.9 percent. 23 Arother illustration of the war motivated

22Davis McEntire, The Labor Force in CaIifornia: A Study of Characteristics and Trends in Labor Force, Employment, and Dccupations in Califorria, $1900-1950$ (Berkeley: University of California Press, 1952), pp. 39-40. 198. 23Infra, Tables B and D, Appendix II, pp. 196 and 
manufacturing growth in the Bay Area is seen in the employment comparisons in Chart 1. Graphically, one sees that of three industries exceeding 60 percent growth from 1939 to 1950, two were nurtured greatly by the war--chemicals and instruments. Both of the industries with between 50 and 60 percent growth were in the war-related group--machinery and electrical machinery. Finally, metal grew 36 percent, rubber climbed 34.4 percent, and petroleum and coal reached 32.5 percent. Only transportation equipment declined, and this can be explained by the shipbuilding decrease and the fact that aircraft production remained in southern California. Among those industries not primarily nurtured by the war, only the motor vehicles, paper, and lumber industries grew in excess of 30 percent.

McWliliams challenged the importance of the war's influence on the industrial growth of the state during the forties $;^{24}$ however, the evidence would seem to substantiate the great impact of the war. Certainly geography, climate, eastern Industrial plant obsolescence, and the desire of eastern companies to establish branches in the West were important growth factors. Yet it wolld appear that without the war the attractiveness of the first two factors, the realization of the third, and the desirability of the fourth might not have been so quickly nor simultaneously recognized. 


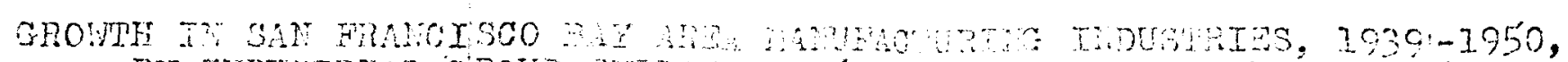

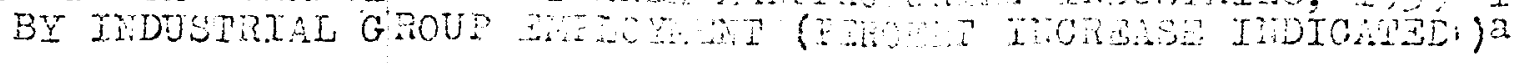

Food ard rindrod productis

Tobacco Varufactuners

rextijo M111 Products

Aporei

Tumbor and Hood poducts

Furniture end Fixibuses

Faper and Alided Productis

Fuintirg and publishing

Gomicals and Froducts

Etroloum and Coal.

Robar and prowucts

Latinor and Products

Bbone, olay, and olass

Perrou-Ionerrous lotals

lachinory (ronolectrical)

Etoctrical rachinem

Notor Venicles

other Pransportation Aquprent

Instmuant Incustrises

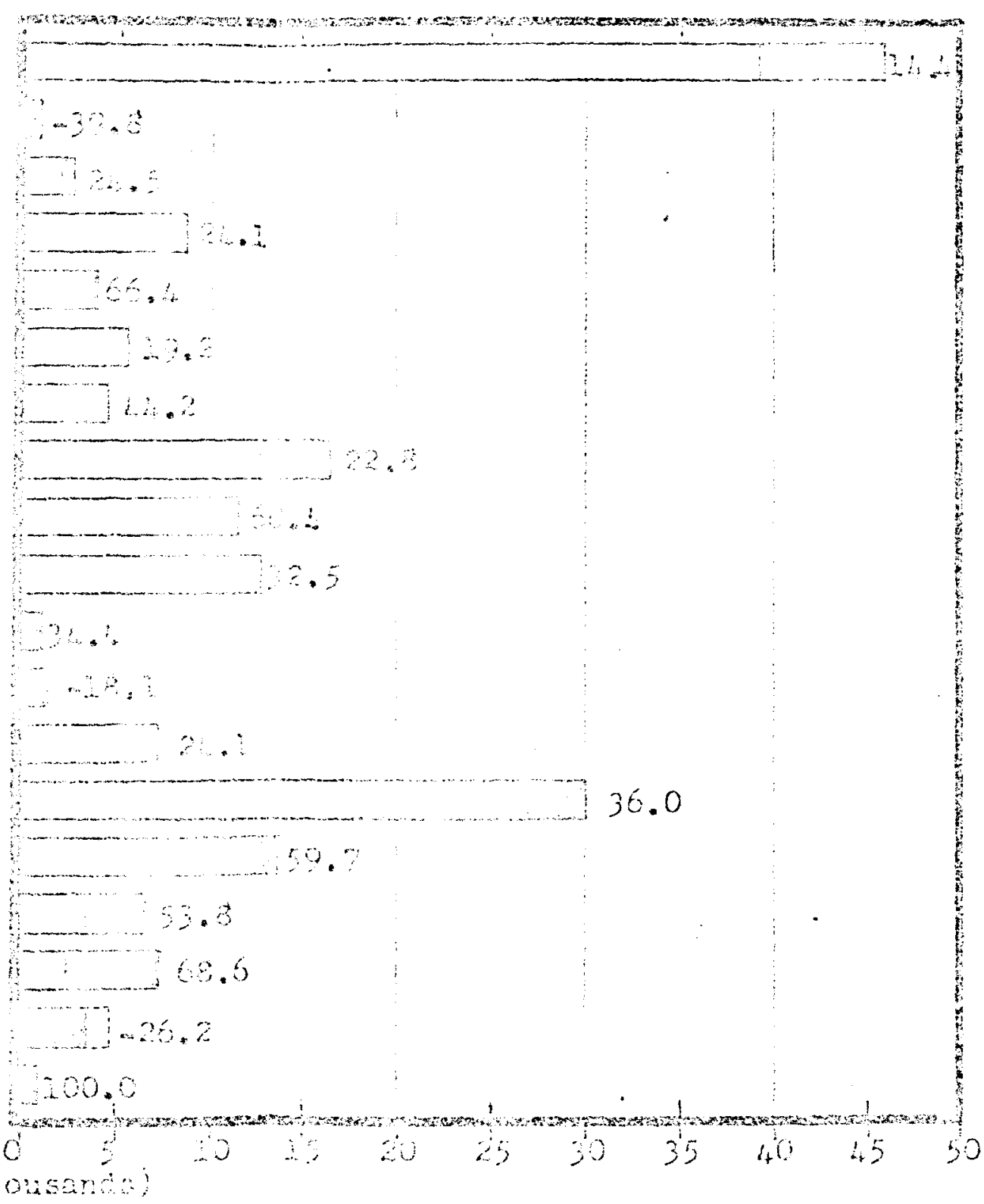

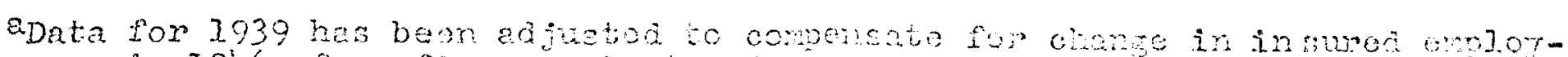

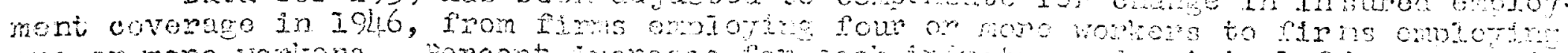

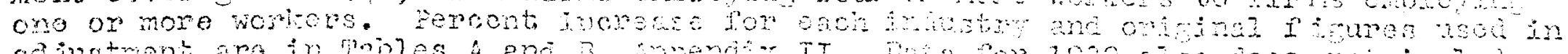

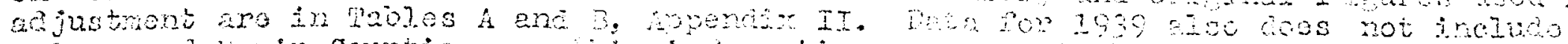

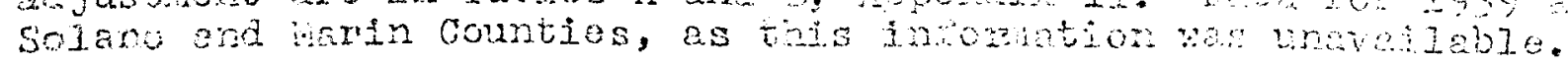

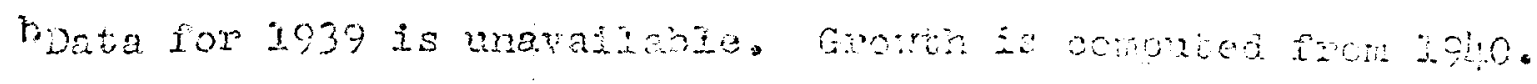

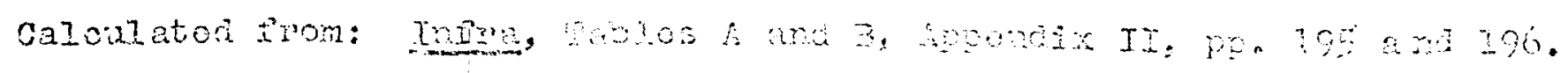


Granting that continued expansion during the postwar period, 1946 to 1950, was important in 1tself, nevertheless, the impetus for such growth unquestionably came largely from the "wartime boom."25

The remarkable postwar reconversion of the California economy has prompted many to comment upon the state's excellent resiliency, 26 for reemployment snags and investment snags were much less than seemed to have been anticipated. The tone of the Reconstruction and Reemployment Commission's report covering the perlod to 1944 showed deep concern about the coming reconversion period, and the State Chamber of Commerce was equaliy worried. The latter group observed, during the second year of the war, that reconversion was indeed a "challenging problem"; and it hoped the war-born industrial facilities, labor force, and raw material resources would provide the ingredients for a solution to the expected problem. 27 The anticipated problems were profuseiy studied. The Reconstruction and Reemployment Commision, for exampie, conducted hearings throughout the state

25Michael A. Goldberg and Gerald R. Walter, "Forecasting Employment and Industrial Location in the San Francisco Bay Area," California Management Review, XI (Summer, 1968), 23 , characterize World War Two as a "take-off period" for the Bay Area economy.

26 McEntire, Labor Force, p. 4I; McWilliams, California, chap. i, passim; Gershenson, "Employmert Trends," pp. 584-85; et al.

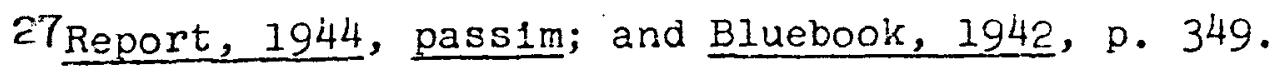


to assist local communties in their efforts to meet reconversion. The Bay Area results were good. In response to hearings held in Oakland in August, 1944, local leaders established the San Francisco Bay Region Counc1l to coordinate a united reconversion effort between government and business. The new organization's first meeting in December, 1944, was followed by planning sessions by a large number of official and unofficlal Bay Area groups in 1945,28 and this effort undoubtedly had a favorable impact on the actual reconversion.

The void left by the decline of war manufacturing allowed an unfilled demand for housing and consumer goods to be realized in the postwar era. 29 In the state, for example, residential investment was 45.6 percent higher in 1946 than In 1939, and by 1949 it had increased 41 percent over 1946. Nonresidential construction also experienced similar growth, climbing 84.8 percent between 1945 and 1946. At the same time, the state began a program of highway, residential, and public construction which added millions of dollars to these industries. Finally, the military departments of the

28 Scott, Bay Area, pp. 261-70.

29 W. W. Rostow, "The Dynamics of American Society," in Postwar Economic Trends in the United States, ed. by Ralph E. Freeman (New York: Harper \& Brothers, Publishers, 1960), p. 6. See also, Gershenson, "Employment Trends," pp. 576-88, which contains a good discussion of Californta recovery. 
federal government continued a high level of construction spending in the state--a level which was 15.5 percent of the national total in 1949.

The San Francisco Bay Area, naturally, was bound to share the state's economic experience. Here, too, the pentup demand for houses, industrial plants, schools, and community centers existed. 30 Construction spending, particularly military, showed a burst of energy. Instead of returning to a small scale operation, the San Franciscc Port of Embarkation was a mainspring of the new Army Transportation Corps, active because of both the Pacific military occupation forces and the need for readiness in the atomic age. 31 Therefore, all types of military expenditures came to the Bay Area (see Table 8 for construction expenditures). Particularly interesting was the continued investment in industrial facilities from 1945 to 1949, as branches of eastern companies moved into the area to accelerate local industrial investment. As Table 9 reflects, almost $\$ 1.3$ billion was invested in 7,502 new and expanded plants, and 39 percent of this was expended in the Bay Area.

Consumer manufacturing coupled with the trade, service, and the remaining nonmanufacturing industries far

$30_{\text {Scott, Bay Area, }}$ pp. 271 ff, contains a good discussion of Bay Area postwar developments. 94.

3I Hamilton and Bolce, Gateway to Victory, pp. 193- 


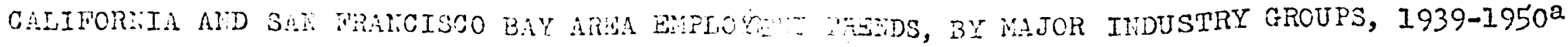

\section{salionga}

- Mnueneturine Endustries

- - Contrid, Costariston

-r-t- Finance, Insumence Iead Estate

(t)cisenats)

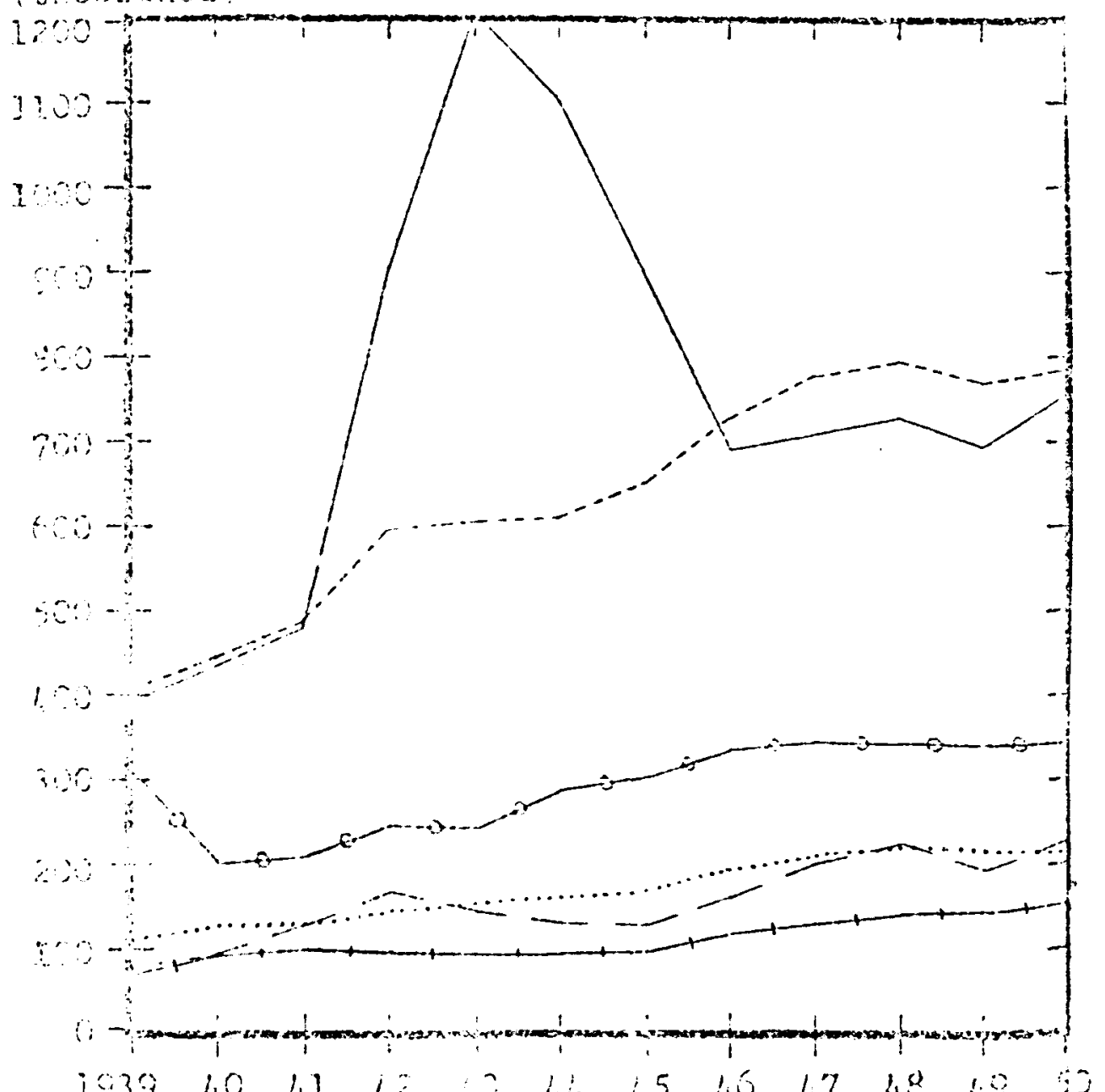

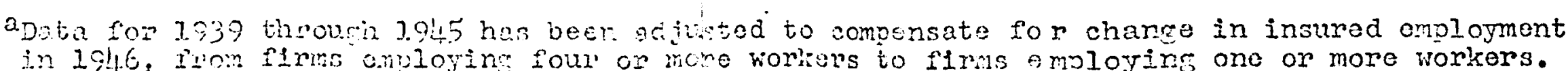

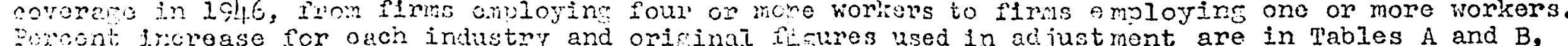
dopendixis.

count.y.

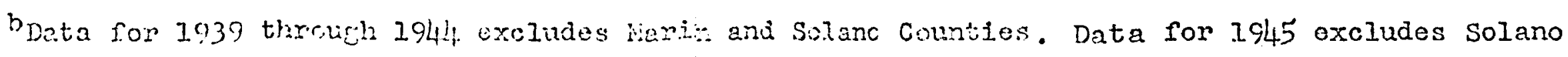
Culculated from: Infra., Tribles $A$ arra E, Appendix II, pp. 195 and 196.

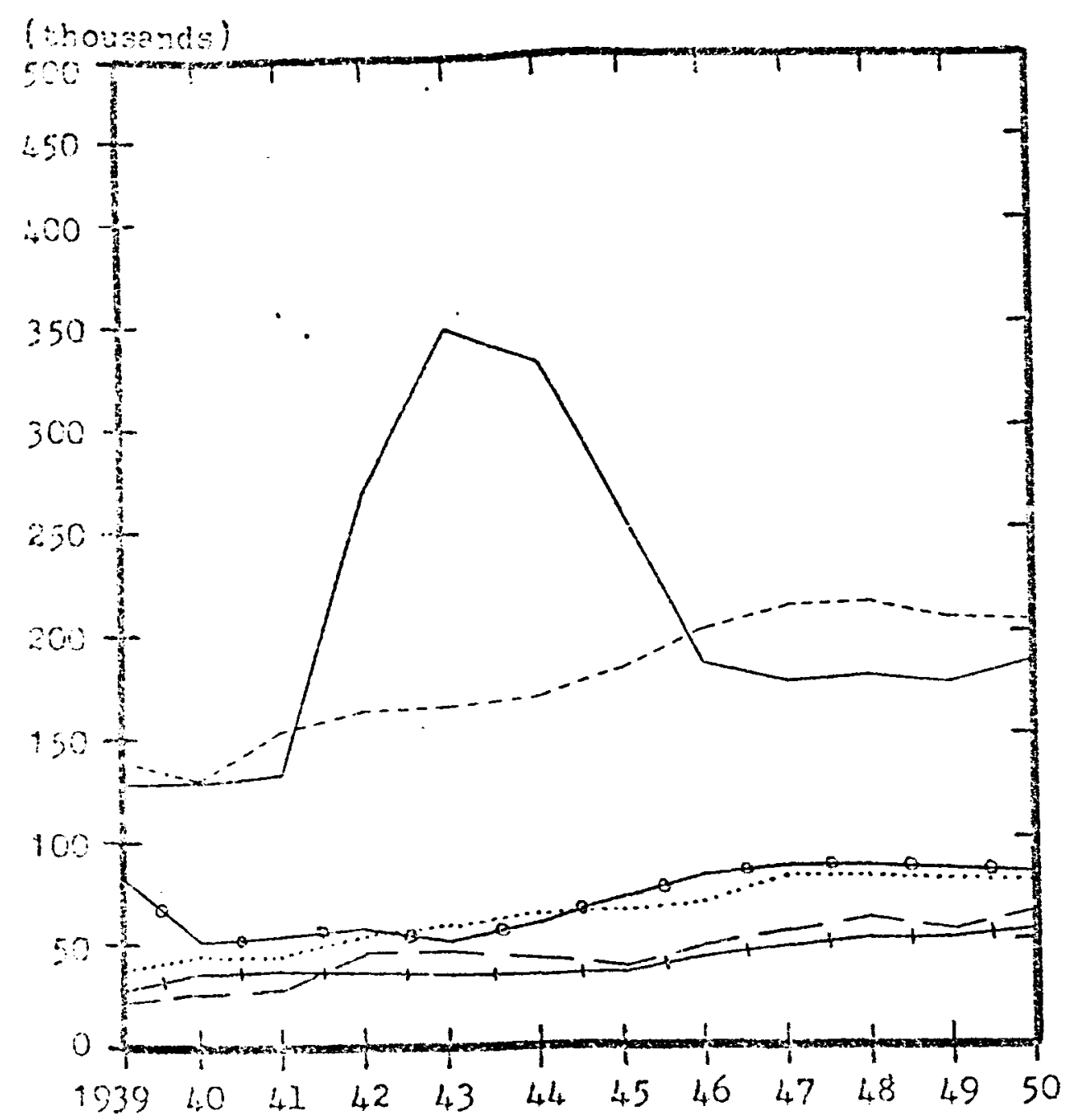

San Francisco Bay freab

........... Transportation, Commo, Utilities

-o..... Service Industries

Industril Trade 
TABLE 8

NEW CONSTRUCTION INVESTMENT IN CALIFORNIA, 1939-1949

(In miliions)

\begin{tabular}{|c|c|c|c|c|}
\hline Year & Residential & Nonresidential & State & Mi11tary \\
\hline $\begin{array}{l}1939 \\
1940 \\
1941 \\
1942 \\
1943 \\
1944 \\
1945 \\
1946 \\
1947 \\
1948 \\
1949\end{array}$ & $\begin{array}{r}411.2 \\
413.3 \\
458.0 \\
239.5 \\
108.9 \\
206.0 \\
247.8 \\
758.3 \\
1,145.1 \\
1.723 .8 \\
1.267 .9\end{array}$ & $\begin{array}{r}\$ 94.0 \\
133.5 \\
227.4 \\
69.8 \\
40.7 \\
51.8 \\
70.9 \\
465.1 \\
417.2 \\
445.9 \\
364.3\end{array}$ & $\begin{array}{r}\$ 261.1 \\
258.6 \\
523.2 \\
794.8 \\
514.5 \\
462.5 \\
417.6 \\
261.4 \\
320.9 \\
411.0 \\
541.9\end{array}$ & $\begin{array}{r}\$ 25.2 \\
* \\
* \\
* \\
* \\
* \\
* \\
* \\
41.9 \\
22.8 \\
21.2\end{array}$ \\
\hline
\end{tabular}

*Data not available

Source: California, State Chamber of Commerce, "Economic Survey of California and Its Counties," in Californla Bluebook, 1950 (Sacramento, 1950), pp. 780-81.

exceeded construction in employment and wages paid. As shown in Chart 2 and in Tables $A$ and $B$, Appendix II, employment growth took place in all these areas. In the Bay Area, trade, manufacturing, service, and the transportationutilities groups all exceeded construction in postwar employment, and a similar relationship is seen in wages (Table $D$, Appendix II). But, the continued growth of the state economy can, perhaps, best be judged by the total net income payments to residents. These followed an upward trend, increasing 80.4 percent during the decade (Table 10). 


\section{TABLE 9}

POSTWAR INDUSTRIAL FACILITY EXPANSION AND COST, CUMULATIVE TOTALS, 1945-1949

\begin{tabular}{|c|c|c|c|c|c|c|}
\hline & \multicolumn{2}{|c|}{ New Plants } & \multicolumn{2}{|c|}{ Expansions } & \multicolumn{2}{|c|}{ Total } \\
\hline & Number & $\operatorname{Cost}^{2}$ & Number & Cost ${ }^{a}$ & Number & Cost ${ }^{a}$ \\
\hline $\begin{array}{l}\text { San Francis- } \\
\text { co Bay } \\
\text { Areab }\end{array}$ & 1,881 & $\$ 204.0$ & 1,478 & $\$ 315.4$ & 3,359 & $\$ 515.5$ \\
\hline $\begin{array}{l}\text { Los Angeles } \\
\text { County }\end{array}$ & 1,074 & 237.1 & 1,844 & 292.7 & 2,918 & 529.8 \\
\hline California & 3,783 & 580.3 & 3,764 & 718.4 & 7,502 & $1,298.8$ \\
\hline
\end{tabular}

a Amount expressed in millions of dollars.

bIncludes twelve countles according to source; however, these are not enumerated and no other sources could be found using this county breakdown for the Bay Area or giving similar figures for the standard 7 county Bay Area.

Source: California, State Chamber of Commerce, "Economic Survey of California and Its Counties," in Callfornia Bluebook, 1950 (Sacramento, $1950)$, p. 785 .

During the postwar period, then, a moderate climb was evidenced in all areas of employment, except manufacturing. Those Bay Area manufacturing jobs which fell into obsolescence by 1945 were replaced by 24,422 positions in the construction industry, 7,725 in the transportationut1lities group, 23,514 in wholesale and retall trade industries, 18,533 in the finance-insurance-real estate group, 
TABLE 10

CALIFORNIA NET INCOME PAYMENTS.

$1939-1949$

(In millions)

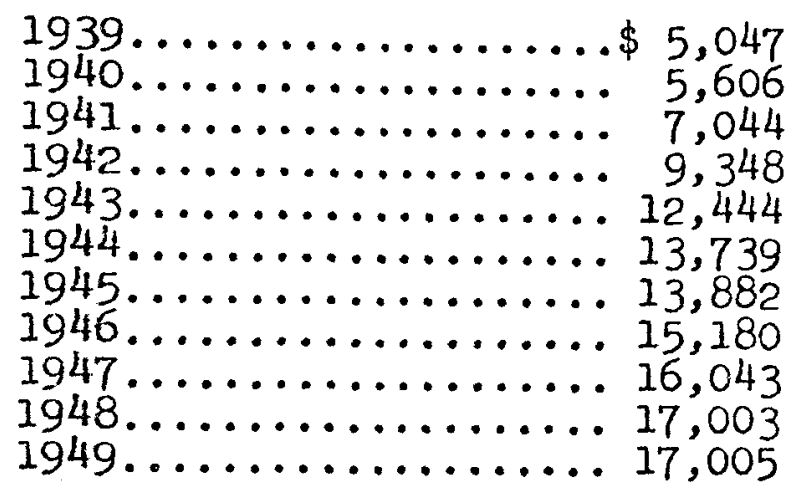

Source: Californla, State Chamber of Commerce, "Economic Survey of California and Its Counties," in Callfornia Bluebook, 1950 p. 769 .

and 10,467 in the service industries. 32 The postwar reconversion period was, indeed, quite free of hardship. In fact, In Santa Clara County, at the south end of the bay, growth was exceptionally favorable. According to one county plannlng report business analysts contended the county would maintain and probably improve its wartime employment level. Its location to the Pacific coast; good transportation faclities; low power, water, and fuel rates; low tax rates; and reasonable land rates were quite attractive to new

32 Infra, Table B, Append1x II, p. 196. Figures are the difference between employment in 1945 and 1950 . 
industry. The establishment of the National Advisory Committee for Aeronautics research and testing facillty at Moffett Field, at the close of the war, suggested that the county would have a bright industrial future. 33 The influx of Industry was rather good. Between 1945 and 1949, 47 new industries invested $\$ 24,545,000$ in the previously agriculturally dominated county. In addition to this new Industry, 123 plant expansions led to the investment of $\$ 11,938,775$ in facilities. 34 The impact of industrlal growth was so great that the county's agricultural interests began to express significant fears that their land would soon disappear and that pollution would soon inundate the valley. Of course, the county supervisors and the San Jose Chamber of Commerce did their best to assure the apprehensive citizens that the new industry was not incompatible with desirable living conditions. 35 Regardless of the fears of agricultural interests, postwar growth in all fields continued at a moderate pace.

The decade ended when preparedness for the Korean

33Santa Clara County, Planning Commission, Master Plan of Airports, Santa Clara County, California (San Jose, California, 1946), pp. 6 and 10.

34 Santa Clara County Chambers of Commerce, Research Committee, Data Sheet, Santa Clara County, 1967-1968 (San Jose, California, 1968), unpaginated (Hereinafter raferred to as Data Sheet).

35 scott, Bay Area, p. 273. 
41

war launched another rise in manufacturing. 36 The effect of the war was similar to World War Two's Impact on the economy, though it was not as disruptive, for the state and the Bay Area had the Industrlal base for expansion. From July I, 1950 to December 31, 1956, California was the leading reciplent of defense contracts in the nation, obtaining 16.4 percent of the total primary awards. In the five years between the two wars the state had managed to secure 7.7 percent more of the nation's defense contracts, placing both Michigan and New York into the second and third positions. Furthermore, as the nation increased defense expenditures in number and size, California's percentage of the awards grew. Rising another 7.6 percent, California's percentage of the nation's awards totaled 24.0 between 1959 and 1960.37 World War Two had given Califurnia and the Bay Area the industrial potential necessary to capitalize upon the skyrocketing Cold War defense budget that came in the fifties. Likewise, the forties had prompted a tremendous population influx to which all segments of the state and Bay Area economy responded by steady growth. As defense-oriented Industry bcomed in the late fifties and early sixties, many realized, as had Engelbert, that ". - If changes in the international situation should result in a decline in

36 McEntire, Labor Force, p. 41.

37 Infra, Tables A and B, Appendix I, pp. 189 and 190. 
defense expenditures, the western economy would be hurt." 38 In response to any dismay over a decilne in the Californta economy, federal officials and others associated with the military-industrial complex suggested that the Cold war and consequential defense spending would continue for many years. In a study of the Bay Area's prospects in 1959, the Department of Commerce noted that the ". . Bay Area wiIl retain its well-recognized position as the regional headquarters for many government and military functions."39 In 1960, Abraham J. Siegel and Charles A. Meyers stated total peace and total war were equaliy remote possiblilties for the relatively near future. 40

38Engelbert, "California's Growth," p. 31. Also see, Emile Beno1t, "Economic Adjustments to Disarnament," in D1sarmament and the Economy, ed. by Emile Benoit and Kenneth E. Boulding (New York: Harper and Row, Publishers, 1963), pp. 272-80, passim; Kevin Keane, "The Cost of the Arms Race," America, october 2, 1965, pp. 372-75; and, particularly, miscelianeous testimony before, U.S., Senate, Committee on Forelgn Relations, Control and Reduction of Armaments, HearIngs, before a sub-committee of the Committee on Foreign Relations, Senate, 84 th Cong., $2 d$ sess., 1956, and 85 th Cong., lst sess., 1957.

39U.S., Department of Commerce, Future Development of the San Francisco Bay Area, 1960-2020 (Wasinington, D.C.: Government Printing office, 1959), p. 8 (Hereinafter referred to as Bay Area, 1960-2020).

40 "Continuity and Charge in American Labor Problems," in Postwar Economic Trends in the United States, ed. by Ral ph E. Freeman (New York: Harper and Brothers, Publishers, 1960), p. 215 . 
III. THE FIFTIES-A PERIOD OF GROWTH

The California economy has been sustained by a number of economic revolutions. The gold fields of the mid1800 's; the rise of wheat farming in the latter half of the 1800 's; the turn of the century growth in diversified agriculture, food processing, lumber, and petroleum; the movie industry of the 1920's; the aircraft industry of World War Two- all have made their impression on the state. These were the surges, according to a report from the Callfornia State Planning office, that raised the state's economy to its present level. This 1968 report stated:

Each surge phased into the economy in its own time and each has followed a somewhat different path over the years. Each was therefore important--and the contribution each made to California's development would have been difficult, if not impossible to predict at the onset of its growth. 1

During the postwar years, the growth of durable manufacturIng neared 30 pexcent. If aircraft and shipbuilding are not included in the percentage, the growth rate rises to 40 percent or more. However, speculation about the development of the state economy without the defense industries is purely academic, for the course of events gave the aircraft

${ }^{1}$ California, State office of Planning, Californda State Development PIan Program: Phase II Report (Sacramento, 1908), p. 32 (Hereinafter referred to as Phase II Report). 
industry a dominating role in the economy. 2

The outbreak of hostilities in Korea precipitated the surge which controlled the California economy in the 1950's. The state employment pattern underwent a major change reflecting the growth in aircraft and other defenserelated industries. 3 Manufacturing employment increased 23.2 percent between 1949 and 1951--an increase not experienced since the beginning of World War Two. Transportation equipment, primarily alrcraft, led the manufacturing sector's increase, its employment growing 39.1 percent. Following transportation were nonelectrical machinery (31.2\%), lumber and wood $(20.7 \%)$, electrical machinery (26.9\%), primary and fabricated metals (26.7\%), and chemicals (26.3\%). Nonmanufacturing employment increased only 8.2 percent during the same period. Representative of the changing requirements of defense technology, the chemicals industry experienced a much smaller employment increase between 1949 and 1951 than the 32.6 percent increase which had occurred in the industry between 1939 and 1942.4 By the 1960's,

\section{Ibid., p. 71.}

3California, Department of Industrial Relations, Division of Labor Statistics and Research, Employment Trencis in California (Sacramento, November 4, 1954), p; 4 (MimeoCurrent Business, February, 1952, pp. 1-4, point up the economic Impact of the Korean War.

${ }^{4}$ Computed from infra, Table A, Appendix II, p. 195. Statistics on growth in only the alrcraft industry can be 
according to Paul W. Crappuchettes of Iitton Industries, chemicals was, in fact, no longer considered a defense industry. 5 As a defense industry, it had reached its apex during World War Two.

The Bay Area, too, shared the growth prompted by the Korean War. Employment changes similar to those noted at the state level were reflected in the local region. Manufacturing employment increased 14.6 percent between 1949 and 1951; and, while not as great an increase as at the state level, the growth was significantly larger than the local 6.5 percent rise in the nonmanufacturing sectors. Transpor tation, however, did not lead the growth in defense-related Industries in the Bay Area. Its 17.8 percent increase trailed far behind the 38.4 percent rise in electrical machlnery employment and was also smaller than the 27.4 percent growth in nonelectrical machinery and 23.1 percent rise in metals employment. 6

found in California, Department of Indistrial Relations, Division of Research and Statistics, Employment and Earnings in the California Alrcraft Industry, 1940-53 (Sacramento, 1954), pp. 1-5, passim, which graphically points out the $279 \%$ Korean War increase in the industry's employment (Hereinafter referred to as Alreraft Industry, 1940-53).

5California, Employment Relations Agency, Engineering Employment in California: A Conference by tre California Soclety of Professional Englneers and the Calliomia state Employnent Relations Agency. Transactions (Sacramento, I956), p. 88 (Hereinafter referred to as Engineering Employment).

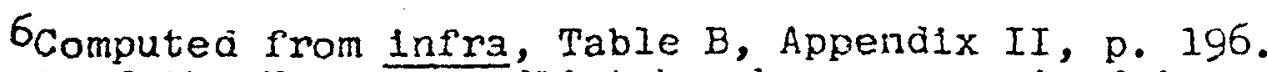
The Impact of the Korean confict has been recognized in 
Unlike the southern portion of the state, the bay region did not appear to have one mushrooming defense industry. As G. E. Pitts, analyst for the State Department of Employment, noted in 1953, the major Bay Area defense Industry was shipbullding and repair, and few contracts had been let in that particular sector. 7 In Solano County, of course, shipbuilding was the major industry; and the state Department of Employment realized that the county's future economic prosperity depended to a large extent on the volume of activity by its largest employer, Mare Island Naval Shipyard. Yet the World War Two shipbuilding boom was not to be repeated. The impact of national defense needs were felt elsewhere. In Contra Costa County, war needs were reflected in the steel, chemical, and rubber industries--the first by far tine most important--and the State Department of Employment noted that ". . . the national defense program will result in increased industrial activity in the

several reports, Including one which appeared in the San Jose News, March 8, 1968 (Hereinafter referred to as News, regardiess of issue); and in Santa Clara County, Planning Department, A Study of the Economy of Santa Clara County, California, Part I (San Jose, California, 1967), p. 9 (jiereinafter referred to as Economy of Santa Clara County); and U.S., Department of Labor, Bureau of Employment Security, Area Manoower Guidebook: 174 Metropolitan Labor Market Areas (Washington, D.C.: Government Printing ofilce, 1957), p. 26 Herelnafter referred to as Area Manpower Guidebook).

7Urban Land Institute, Findings, Recommendations and Record of Proceedings of the Industrial Development Stucy for San Mateo County, Californta (Washington, D.C.: Urban Land Institute, 1953i, p. 24 . 
community. "8 Elsewhere in the bay region the growth in the electronics industry was recognized, particulcrly in the Palo Aito area. The industry, which had sprouted in Santa Clara County in 1940, had experienced signiflcant growth as a result of new defense requirements. 9 Alrcraft production, which during World War Two had been small and primarily centered about modification work by the Matson Navigation Compary, did not grow significantly. The only producer was, in fact, the Hiller Aircraft Company in Palo Alto, which produced helicopters for the commercial market. This company did experlence a shift to the military market; but, as it was the leading commercial helicopter producer, the increase prompted by defense requirements was probably quite small during the Korean War period. 10

In a 1961 report the State Chamber of Commerce

noted: "The phenomenal expansion of the industries oriented to national defense was clearly the key to the rapid growth

${ }^{8}$ California, Department of Employment, Research and Statistics, Community Lador Market Surveys, California, 1952 (Sacramento, 1953), unpaginated. (Mimeographed.)

9Ib1d.; and, Santa Clara County, Planning Department, Background: Santa Clara County California, A Summary Overvlew of the Location, Topography, Climate, Population, Income, Economic History, Principle Ecoromic Activities, Labor Force, Economic Problems, and Resaurces for Development in Santa Slara County, California CSan Jose, California, December, 1966), p. 3 (Hereinaf'ter referred to as Background: Santa Clara County).

10 WIIlam Glen Cunningham, The Aircraft Industry: A Study in Industrial Location (Ios Angeles: Lorrin I. Morrison, Pubilsher, 1951), pp. 95, 156, and 164. 
of California since 1947." The Chamber also reported that the increased employment in these industries ". . plus the stimulus it provided to employment in the trades, services, and other similar industries, was responsible for at least half the total growth occurring in the state over the 1947-57 period."1l The state's manufacturing employment, which had grown 44 percent during the decade following 1947, certainly had prompted the 16.9 percent growth in nonmanufacturing employment. Similarly, the 21.2 percent Bay Area manufacturing employment increase during this period had much to do with the 31.6 percent Increase in local nonmanufacturing industries. The San Francisco area's prominence as a financial and tourist center can, perhaps, account for the great difference in relative nonmanufacturing increase compared to statewide changes. Yet this factor should not discount the importance of the impact of manufacturing growth. According to a report by the Santa Clara County Planning Department in 1960, a single industrial job at that time theoretically attracted eight to ten new residents and generated about 1.5 nonmanufacturing Jobs. 12 As Table 11

IlCallfornia State Chamber of Commerce, Summary of "The California Economy, 1947-1980" (San Francisco: Cai1fornia State Chamber of Commerce, 1961), pp. 4, 7, and 18.

12 Santa Clara County, Planning Department, Facts and Forecasts: A Supplement to the General Plan of Santa Clara County (San Jose, California, October, 1960), pp. 28 and 40 (Hereinafter referred to as Facts and Forecasts). Other studies clted later in this study also suggest the $I$ to 1.5 ratio of jobs generated. 
TABLE 11

NONMANUFACTURING EMPLOYMENT INCREASE IN CALIFORNIA AND THE BAY AREA, 1947 - 1957

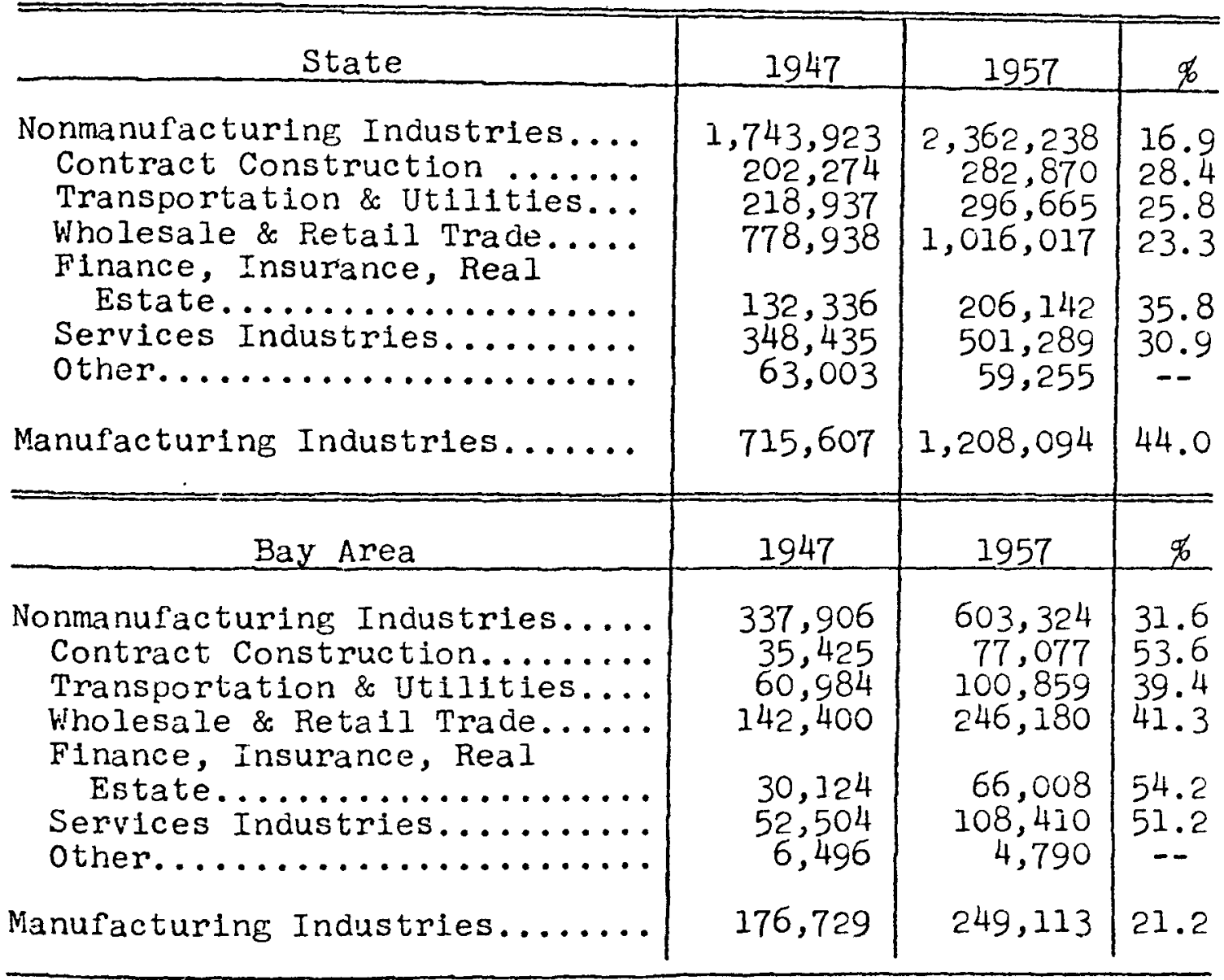

Source: Computed from infra, Tables $A$ and $B$, Appendix II, pp. 195 and 196.

indicates, all major nonmanufacturing employment rose appreclably between 1947 and 1957, both in the state and the bay region.

The end of the Korean conflict did not have nearly the same economic effect on California and the Bay Area as had the cessation of World War Two. Although defense spending fell off, it remained at a much higher level than it had 
in the late 1940's. "The major reason that California's defense-orlented industries were not reduced in size by the cease-fire in Korea," stated one state report, "was to be found in the rapidly developing revolution in weapons technology."13 The birth of the Intercontinental Ballistic Missile (ICBM) and the 1957 launching of the Russian Sputnik prompted a great leap upward in United States defense expenditures, and California became a national center for this new defense production. The Bay Area, of course, followed the statewide trend. Cutbacks in Korean War contracts perhaps hit the region harder than the state as a whole, but labor surpluses remained moderate through the 1954 adjustment period. 14

There is Jittle question that the aircraft industry was a sustaining factor in statewide manufacturing employment. Though individual companies might have slumped occaslonally, overall military spending plus commerclal business was generally growing. Even the national policy to disperse key industries geographically as a precaution against enemy attack did not appreciably hurt California's airframe Industry's growth, although it did slow slightly as compared to the nation's aircraft industry growth. The airframe

13Phase II Report, p. 71. See also Economy of Santa Clara County, p. 10; and News, March 9, 1968.

$14^{4}$ rea Manpower Guidebook, p. 26. 
51

industry was not unaware of technological changes, and Cal1fornia's concerns were the first to leap on to the so-called "bird bandwagon."15 Missiles became a common California production item, and not only did the large aircraft concerns benefit. California's more than 10,000 alrframe industry subcontractors and suppliers felt the prosperity boom as well. 16 It was in this new industrial field, missile components and related equipment, that the Bay Area prospered; and it was this field which overtook the once prominent manufacturing position of the area's more conventional defense industries.

In a 1963 study of the Bay Area, Orvilie F. Poland of the Unlversity of Calffornia observed that ". . the most significant economic development during the 1950's was the rapid rise of the electronics industry and other industries related to the new defense and space prograras." 17 The make-up of the entire bay region began a rapid change. The older central core of the area--San Francisco, Oakland, and Contra Costa County--continued to have a diversified economy, based more on trade, finance, and conventional manufacturing

15Aircraft Industry, 1940-53, pp. I and 5; and "West Coast Aviation: Higher and Higher, Faster and Faster," Fortnight, May, 1956, pp. 22 and 25.

16 California, Senate, Fact-Finding Committee on Commerce and Economic Development, Final Report (Sacramento, 2957), p. 56 .

170rvilie F. Poland, Economic Trends in the San Francisco Bay Area (Berkeley: Institute of Governmental Studies, 
than on the new defense industries. Southern Alameda, San Mateo, and Santa Clara Counties now became the centers of growth. The young electronics industry, which had early formed a nucleus around Stanford University in Palo Alto, was sparked by the post-Korean ICBM boom and was ready for further expansion when Sputnik's launching gave the United States space program a high priority. ${ }^{18}$ Led by Lockheed's new Missiles and Space Division, which came to Palo Alto in 1954, an enormous number of new firms flocked to the area. Between 1947 and 1961, San Mateo and Santa Clara Counties gained 835 new industrial plants valued at $\$ 296,139,600$ and had 2,073 expansions valued at $\$ 437,628,040$. Throughout the seven county Bay Area, in fact, such growth was experienced with 8,913 total plant projects valued at $\$ 2,430,545,202$. However, the high value electronics firms located primarily in the south bay area. 19

Franklin K. Lane Profect, University of California, 1963), pp. 1 and 5 .

18 Carl Lindner, "Diversification Progress and the San Francisco Bay Area Electronics Industry" (unpublished MA thesis, San Jose State College, 1967), pp. 23-25, notes that Stanfora began to teach electrical engineering in 1891. The university pioneered the high voltage engineering field and, in the $1930 \%$, fathered the Klystron tube. During the years following Horld War Two, research was renewed with new fervor, and many new firms were attracted to the area. "During this period [1949-1962], the Bay Area developed the largest single concentration of microwave tube manufacturing in the world. The larger share of this growth was attributed to increases in military business..."

I9Bay Area Counc11, Guide to Industrial Locations in the San Francisco Bay Area (San Francj.sco, 1964), .30 ; and 
Santa Clara County's growth perhaps mirrored that of the entire south bay region. The 1950's brought a spectacular shift away from agriculture and canning as the chlef industries. No longer was the county to be known as the "Prune Bowl" of the nation. The San Jose Mercury of January 27, 1963 stated: "An Industrial explosion transformed one of the world's best known farm-orchard centers into an exciting space-age industrial complex."20 Between 1953 and 1956, three glants of Industry settled in the area. International Business Machines (IBM) invested $\$ 32$ million in a new plant to the south of San Jose, Lockheed spent $\$ 91$ milion in the northern portion of the county, and Ford Motor Company constructed a $\$ 60.5$ million facility to the northeast of San Jose. 21 Combined with homegrown industries

Data Sheet. Sources referring to the change in Bay Area Industrial composition and the growth of the electronics industry during this period are much too numerous to include in a single reference. The News and San Jose Mercury (HereInafter referred to as Mercury, regardless of issue), contain many articles in issues during these and subsequent years which refer to this topic. Many articles in periodicals have also referred to the changes and growth. Therefore, the reader is referred to the bibliography of this paper. According to Lindner, "Diversification Progress," p. 25 , 167 electronics firms were in the Palo Alto area in 1962.

20See also Mercury, April 29, 1964 and November 15, 1960; and Robert $W$. Travis, A Study of Industrial Site Development and Site Croice In Santa Clara County--1950 to 1959 (San Jose, California: San Jose State College, Real Estate Research Bureau, n.d.), pp. 1-4. (M1meographed.)

21 Mercury, November 17, 1960. 


\section{4}

such as Ampex, Varian Assoclates, and FMC, the 1mpact was bound to be great. The area was characterize?, not surprisingly, by a great number of firms merging, splitting, disappearing, and arriving. The San Jose area gained recognition at the national level by being designated a standard metropolitan statistical area, and this new SMSA found Itself less linked to local market industrial demand than other areas of comparable size--an indication of the importance of the new aerospace industries to the locality. Drawn by the firmly established scientific complex centered about Stanford University, national firms and federal funds poured into the area. 22 In 1958, the dollar value added by Santa Clara County (San Jose SMSA) Industry was $\$ 671,982,000$, as compared to the United States county average of $\$ 45,112,000$. Ninety-nine percent of the nation's counties were below the Santa Clara County level. 23

Despite the many aerospace industries settling in the south bay region, there always seemed to be room for more. For example, the San Jose Mercury commented: "Each electronics or missile firm which locates in the North

22Santa Clara County, Planning Department, "A Study of the Local Impacts of Research and Research-based Manufacturing: Santa Clara County, California. Summary," by Charles T. Stewart, Info Commentary (San Jose, March, 1967), pp. 3, 6, and 16 (Hereinafter referred to as Info Commentary).

23Background: Santa Clara County, p. 37. 
County helps to strengthen the magnet... . 24 The Industry continued expanding, and local optimism was repeatedly expressed by the local press as the area looked ". . . forward to a breathtaking panorama of future development."25 As long as military spending continued, growth certainly seemed inevitable; and the region's share of the federal defense expenditure had never been larger. "Not even at the height of the Korean War, when military buylng was at a much hlgher level than it is today," said Lleutenant Colonel Oliver D. Burden, Chief of the San Francisco Air Force Procurement District, in early 1956, "was the Air Force equaling today's volume of business on the Peninsula."26 The funds expended by NACA for facilities at Mofiett Field Naval Air Station were also indicative of the overall levels of government defense spending in the area. From the first years of World War Two to June, 1954, a total of $\$ 37,282,412$ was let for facilities and equipment at the Ames Aerospace Laboratories. In 1954 , construction valued at $\$ 38,807,376$ was underway, and an additional $\$ 8,979,930$ was pald in salaries and expenses in FY1955 alone. 27 "Al1 of this

24 Mercury, September 11, 1959.

25Mercury, January 15, 1956. Many other articles praising the aerospace industry and the area's industrial future are too numerous to mention here.

$26_{\text {Mercury, March 5, } 1956 .}$

27 San Jose Mercury-News, untitled fact sheet in the Mercury-News clipping files for 1955 . (Typewritten.) 
construction work has provided employment for hundreds of our friends in the local building trades," claimed the manager of the Greater San Jose Chamber of Commerce; 28 and, without question, most other sectors of the economy shared in the added economic activity.

A study of industrial expansion in a small unnamed community outside the Bay Area was conducted in 1959 by the United States Chamber of Commerce, and it is perhaps iilustrative by comparison of the type of impact felt in the south bay area in the 2950 's. A hundred new factory workers, it was concluded, brought tremendous changes to the entire community. Population increased by 296 , and personal Income rose $\$ 590,000$. A total of 112 new households were established, 4 new retail stores opened, $\$ 270,000$ more bank deposits added, and retail sales grew $\$ 360,000$. Altogether, 74 nonmanufacturing jobs were added--a figure close to the $1: 1.5$ ratio mentioned earlier for jobs generated by manufacturing employment increase. 29 An attempt to compute growth for the south bay area based on this study would be a less than accurate exercise, for the region undoubtedly

28Russell E. Pettit, "Moffett Field" (San Jose, California: San Jose Chamber of Commerce, March 4, 1955), unpaginated MS, San Jose Mercury-News, clipping files for 1955. (Typewritten.)

29 Chamber of Commerce of the United States, Economic Research Department, What New Industrial Jobs Mean to a Com-
muntty (Washington, D.C.: Chamber of Commerce of the United States, 1959), pp. 4-5. 
differed greatly from the area studied by the Chamber of Commerce. As an example, however, this study gave one an indication of the impact of the 1950's manufacturing growth on the south bay region economy.

The south bay region, in fact the whole bay area, experienced growth quite comparable to that shown in the Chamber of Commerce's study. The total population of the Bay Area increased from 2,504,542 in 1950 to 3,461,000 in 1960 , a growth of 38 percent compared to the average national metropolitan area growth rate of 26 percent. However, the south bay region monopolized the increase, as the San Jose SMSA expanded from 288,852 to 658,700 for an increase of 127 percent. An average annual Increase in population of approximately 90,000 flooded the Bay Area.30 Obviously, the majority of this increase was the result of in-migration and not natural increase, although figures were not readily avallable to substantiate the exact breakdown. A 1964 study by the Bank of America suggested that some 76 percent of the growth in the San Jose SMSA was due to in-migration between the mid-forties and mid-sixties, and this would appear to be a reasonable figure. 31

30Poland, Economic Trends, p. 1, suggests the Bay Area population increased 35 percent and that of Santa Clara County grew 121 percent between 1950 and 1960 .

31 Eank of America National Trust and Savings Association, Focus on Santa Clara County: An Economic Study Prepared by Bank of America NT \& SA (San Francisco, 1904), p. 2 (Hereinafter referred to as frocus on Santa Clara County, 1964). 
SAN FRANCISCO BAY AREA POPULATION INCREASE, 1950 - 1965

\begin{tabular}{|c|c|c|c|c|}
\hline County & 1950 & 1960 & 1965 & $\begin{array}{l}\text { \% Increase } \\
1950-65 \\
\end{array}$ \\
\hline $\begin{array}{l}\text { Alameda } \\
\text { Contra Costa } \\
\text { Marin . } \\
\text { San Francisco } \\
\text { San Mateo. } \\
\text { Santa Clara. } \\
\text { Solano . }\end{array}$ & $\begin{array}{r}734,740 \\
297,400 \\
84,739 \\
760,381 \\
234,030 \\
288,852 \\
104,400 \\
\end{array}$ & $\begin{array}{l}912,600 \\
413,200 \\
148,800 \\
741,500 \\
449,100 \\
658,700 \\
137,100 \\
\end{array}$ & $\begin{array}{r}1,032,600 \\
509,600 \\
188,600 \\
743,100 \\
526,900 \\
159,800 \\
159,800 \\
\end{array}$ & $\begin{array}{r}40.5 \\
71.4 \\
122.5 \\
-2.3 \\
125.1 \\
209.5 \\
53.1 \\
\end{array}$ \\
\hline Total .... & $2,504,542$ & $3,463,000$ & $4,054,400$ & 61.8 \\
\hline State.... & $0,643,000$ & $15,853,000$ & $18,726,000$ & 75.9 \\
\hline
\end{tabular}

Source: California, Department of Finance, California Population, 1967 (Sacramento, 1967), Table 15, p. 18 and Table 17, pp. 20-21.

The influx of population during the decade of the flfties naturally prompted other growth. "Population shifts," noted the Bank of America, "are closely tied to changes in economic conditions." 32 Employment, as we have already seen, expanded rapldiy. The economic structure of the Bay Area, particularly the new industrial prospects, acted as a great magnet. As families arrived, the construction industry responded to the demand for homes. New home construction figures for the first half of the decade were scarce; however, data coverling the years after 1955 indicated the Immense building boom that occurred. The Bay Area 
added 189,316 new homes to its landscape between the end of 1955 and the start of 1961. Santa Clara County, alone, accounted for 70,483 of the dwellings--37 percent. 33 The overall employment in the bay region construction industry increased from 64,416 in 1950 to 78,725 in 1960. While a drop of almost 10,000 occurred in 1953 and 1954, the overall growth nonetheless stood at almost 20 percent. The San Jose SMSA, of course, experienced even less a set back in 1953 and none at all in 1954. This area's construction industry employment raced upward from 8,236 in 1951 to 16,278 in 1960, an increase of almost $98 \%$. The finance, insurance, and real estate sector of the economy experienced comparable growth, employment increasing 21 percent in the Bay Area and 125 percent in Sarta Clara County, between 1951 and 1960.34

The trade and service industries of the area also expanded, their growth closely tied to the improved personal income of area residents. The significant rise in income was probably caused in large part by the expansion of the higher paying aerospace industries, particularly in the San Jose SirSA. 35 The total personal income of the bay region in 1950 amounted to $\$ 5.3$ billion and had risen to $\$ 10.3$

33San Jose Mercury-News, Advertising Plans Depart33San Jose Mercury-News, Ad Jose and the Bay Area
ment, Facts About Metropolitan San Jos), unpaginated.

${ }^{34}$ Infra, Appendix II, Tables $B$ and $C, p p .196$ and 197.

35 Focus on Santá Clara County, 1964, p. 3. 
billion by 1960. In the San Jose SMSA income rose even more rapidly, from $\$ 518$ mililon in 1950 to $\$ 1,776$ million in 1960.36 The per capita net buying power in the Bay Area increased $\$ 901$ during the decade, and it grew by $\$ 893$ in the San Jose SMSA. The Bay Area's household buying power rose $\$ 2933$ during this period, and San Jose's climbed $\$ 2963$. The latter figures seemed to indicate the gradual rise in higher income employment in the San Jose SMSA as compared to the entire bay region. This trend was even more evident since the net household buying power in the San Jose SMSA in 1950 was $\$ 1,142$ less than the comparable figure for the rest of the Bay Area, but the difference had lessened to $\$ 83$ by 1960.37

It was only natural for the services and trade industries to respond to meet new and enlarged demand. Retail sales of the region rose quickly as the buying power of the area's families was enlarged (see Table 13). The Bay Area's retail sales grew 83 percent, from 1950 to 1960 , to a level of $\$ 4.9$ billion. This sizable growti, however, was

36 California, Department of Finance, California Statistical Abstract, 1964 (Sacramento, 1964), pp. 174-78; and California, Department of Finance, California Statistical Abstract, 1968 (Sacramento, 1968), p. 55 (Hereinafter referred to as Abstract, 1968).

37 Sales Management, May 10, 1951, pp. 136 and 179; Sales Management, Way 10, 1961, p. 90; and San Jose MercuryNews, Market Memo: Current Trends and Prospects in Metro San Jose and the Nation (San Jose, California, July, 1968), unpaginated (Hereinafter referred to as Market Memo, regardless of date). 
TABLE 13

BAY AREA RETAIL SALES GROWTH, 1950 - 1960 (In thousands)

\begin{tabular}{c|c|c}
\hline Year & San Jose SMSA & Bay Area \\
\hline 1950 & $\$ 302,670$ & $\$ 2,669,110$ \\
1951 & 332,680 & $2,918,051$ \\
1952 & 374,873 & $3,160,257$ \\
1953 & 426,139 & $3,383,212$ \\
1954 & 427,183 & $3,416,498$ \\
1955 & 554,803 & $3,756,882$ \\
1956 & 634,808 & $4,039,351$ \\
1957 & 696,267 & $4,186,575$ \\
1958 & 720,673 & $4,130,683$ \\
1959 & 858,645 & $4,598,982$ \\
1960 & 920,628 & $4,898,852$ \\
\hline
\end{tabular}

Source: Santa Clara County Chambers of Commerce, Research Committee, Data Sheet, Santa Clara County, 19671968 (San Jose, California, 1968), unpaginated; Sales Management, May 10, 1951, pp. 136 and 179; and Sales Management, May 10, 1961, p. 382.

far exceeded by the 220 percent growth of sales in the San Jose SMSA. The employment figures for retail and wholesale business firms naturally followed the dollar growth pattern of the decade, rising 22 percent in the Bay Area and 85 percent in the San Jose SMSA. Service industries, too, experienced comparable growth in the area with employment Increasing 60 percent in the bay region and 174 percent in the San Jose SMSA. 38 Perhaps the best indication of the overall business growth in the area was evidenced in the

${ }^{38}$ Computed from infra, Appendix II, Tables $B$ and $C$, Appendix II, pp. 3.96 and 197 . 
San Francisco business index computed by the San Francisco Chamber of Commerce. Using the monthly averabes from 1947 to 1949 for a base of 100.0, the index rose from 108.5 in 1950 to 157.3 in 1958. Not once during these years did the index fail to rise. 39

The rapid growth of the Bay Area during the decade of the fifites gave rise to questions asking why this area was so fortunate in attracting the industry which was such an important key to the expansion. Many studies have tried to answer why industries choose to locate in the areas they do. One local study plausibly suggests that Santa Clara County's industrialization was really a part of a regional phenomenon. Industries first chose the general area in whlch to move, and then narrowed their site choices down to a specific locality. Generally, several factors were considered by almost all firms in selecting the general area. Access to markets, land abundance, good transportation facilities, good climate, avaliability of labor, abundance of raw materials, educational and research facilities, low taxes, amenities for living, availability of utilities, and the presence of allied or favorable businesses were all

39San Francisco Chamber of Commerce, Research Department, San Francisco and the Bay Area: An Economic Survey and Yearly Revieh (San Francisco, 1959), p. 29 (Th1s is an annual publication and will be hereinafter referred to as San Francisco and the Bay Area, regardless of issue). 
rather important considerations. 40 The locality of the actual site also involved consideration of these factors, but many other items became important to the final selection. IBM, one of the largest companies coming into the region, actually gave the area's rose bushes much credit for prompting the firm's rinal site choice. 41

Perhaps most important to final site selection was the atiltude of the community, and the areas around the San Francisco Bay certainly exemplified excellent attitudes toward industrial growth. The State Planning office noted in a major study that most California regions used, during the post World War Two years, normal economic development techniques. To attract industries, the report stated, communities offered several benefits. Arrangements were made to provide financial terms for plant sites and facilities, speclal loans to newly formed firms were offered, public services were provided free or at inftially low rates, technical and managenent services were made available, tax rates were often favorably adjusted, financlal aid for relocation was made avallable, and development organizations were formed to coordinate industrial growth. 42 The south bay

40 Travis, Study of Industrial Site Development, pp. 13, 18, and 21 .
${ }^{41}$ News, November $17,1960$.
42phase II Report, pp. 76-77. 
region was fortunate in this respect to have the leadership of the Greater San Jose Chamber of Commerce. The organization's manager of many years was highly praised by the local press for his work in bullding the present Santa Clara County economy: "More than any single man, perhaps, Russ Pettit was responsible for the transformation of San Jose from an agricultural community to a leading electronics and aerospace metropolis." 43 In the 1950's, several community leaders--including Pettit, Elystus L. Hayes of the San Jose Mercury, and Frank C. Mitchell of the Bank of America--began a major push to diversify the prune-oriented economy of the county. A national campaign was launched to attract industry. According to Pettit, the drive was based upon persistence, spirit, advanced planning, glossy brochures, aerlal photographs, surveys, national advertising, classifled notices, anà much luck. By 1960, Pettit and San Jose's City Manager, A. P. Hamann, had succeeded in having San Jose designated as an "All American C1ty," which was undoubtedly an attractive drawing card to new industries. Companies had responded to the drive in gratifying numbers, for there were 807 inaustrial plants in Santa Clara County by November, 1960.44

43Mercury, July 3, 1969.

44 News, November 16, 17, 18, and 19, 1960. 
By 1960 the Bay Area could boast of tremendous advances. Its economlc growth had been generally consistent with the national growth pattern except in the manufacturing sector, where the region reversed the national trend of declining manufacturing employment to relative total employment. The key to this local growth in manufacturing was possibly found in the expansion of the south bay region growth and the steady industrial activity in the Contra Costa County area. In any case, manufacturing became more lmportant, although not as blue-collar oriented as throughout the rest of the nation. As the decade of the fifties ended, the Bay Area's economy had completed a radical change. The core of the area had increased its importance as a major port facility, center for north-south coastal trade, financial center, and reglonal office and distribution center. 45 The agricultural sector of the region, particularly in the south bay area, had aecreased considerably; and the infant aerospace and electronics industry had burst into maturity, more than filling any volds left by the decline of the foods industry.

The structure of the regional economy at the close of the decade was, perhaps, best 1llustrated by a state sponsored analysis of the markets of the San Francisco-

45Poland, Economic Trends, pp. 2-5. 
Oakland Metropolitan Area at the end of 1959.46 While the San Jose SMSA was not included in this particular analysis, it should be recognized that the area was closely tied to the San Francisco-0akland SMSA. Therefore, the analysis gave a relatively sound approximation of the general nature of the overall regional economy.

Breaking the output of the varlous local industries Into demand sectors, the state research team was able to determine the approximate distribution of total employment to markets. For example, 96,900 manufacturing employees ( $47.5 \%$ of the total manuiacturing employment), initially produced goods for the private exports demand sector (those locally produced goods which leave the region under consideration, except those that leave via sale to the federaj. government). In addition to the private exports sector, the study defined sectors for government exports (sales to the

${ }^{46}$ California, Economic Development Agency, Markets for Callfornia Products: An Analysis of Sources of Demand, by W. Lee Hansen, R. Thayne Robson, and Charles M. Tiebout (Sacramento, 196i) (Hereinafter referred to as Markets for California Products). Studies investigating the destination of products produced in a region are few. This is the only partlally comprehensive such analysis for California. In the San Francisco-Oakland area, the researchers contacted all firms of over 100 employees as of the third quarter of 1959 plus conducting a random sampling of smaller establishments. Their questionnaires were returned by approximately 25 percent of the firms contacted. Readers interested in the exact methods of the analysis should refer directly to the study, for the methodology is complex at best. The questionnaire used in the study was slightly modifled by this writer and used to obtain more current data (Infra, Appendix III, pp. 204-07). 
federal government), local consumption (purchases by local consumers), housing investment (local family housing unit construction), business investment (local business investments in plants and equipment), current government (day-today government activities, including some federal government), and government investment (investment activities of local and locally orlented government units). 47 As seen in Table A, Appendix III, the markets analysis for the Bay Area revealed much about the region's economic structure--what goods were exported, to what sectors of the economy goods went, the relationships between various industry groups and demand sectors, what demand sectors were most important to the Bay Area and to specific industries within the region, and so forth.

Initial sales of local industry groups in the area were quite diversifled in 1959. One-fourth of the total employment of the region produced for the export market; one-half was split between production for local industry Groups and consumers; and the remaining one-fourth produced for the business investment, housing investment, current government, and government investment sectors. A detalled analysis of at least one broad industry group should be sufficient to see the importance of the various markets to the bay region. In the manufacturing industry group,

$$
\text { 47Ib1d., p. } 15 .
$$


47.5 percent of the group's employees made products which were initially sold to the private exports sector. The remaining employees divided their production efforts between sales to government exports $(9.9 \%)$, local consumption ( $7.2 \%)$, business investment (2.6\%), government (1.4\%), and all local Industry groups ( $31.4 \%)$. When the manufacturing employment which was credited to 211 local industry groups $(31.4 \%$ or 64,000) was distributed among the sectors to which their production efforts finally went, the actual market distribution became clearer. The private export market made possible 57.6 percent of the total manufacturing employment, the government export sector provided for 12 percent, local consumers made possible 23 percent, and the adaitional sectors accounted for the remaining 7.4 percent of manufacturing employment. Of course, these figures were considered only approximations. Using a much less complex method of determining the percentage of manufacturing employment producing for outside or export markets, the author estimated that 51.7 percent of the employees produced for the export sector. 48 This was somewhat less than the 57.4

$48 \mathrm{Calculated}$ from, Bay Area, 1960-2020, pp. 34-36; and infra, Table $B$, Appendi $\bar{x}$, p. 196 . The method used by the Department of Commerce and the author to obtain percentages of outside market employment is known as the "minimum requirements" method. This approach compares the employment structure of a city or metropolitan area with the structure of other cities or metrocolitan areas in the same size-class. The employment structure of the areas in the given size-class is measured with each industry expressed as a percent of total local employment, i.e., 
percent employed for the initial private and government export sectors noted above, and less st1ll than the 69.6 percent employed for the final demand export sectors. The discrepancy, however, might have been accounted for by the fact that the percentages used by the author were intended for use with data for 1950, not 1959. Perhaps the discrepancy should have been best used to suggest the shift in manufacturing export markets. A dissimilar discrepancy existed for total employment in the area. While the Department of Commerce study used by this writer suggested 40.1 percent of the area's total employment produced for the export market, the California market analysis estimated that 28.0 percent of the total employment initially went to export markets and 34.5 percent of the employment went to export markets in the final demand. The reverse discrepancy was, perhaps, accounted for by the growth of

\section{$\frac{\text { No. Persons Employed in a Given Industry in the Area }}{\text { Total No. Persons Employed in the Area }}$}

The ratio attalned is compared with a determined minimum deemed necessary to supply the local population with the goods and services within each industry required by an area of the given class-size. Generally, the minimum local area employment demand for goods and services is the equivalent of the lowest percentage that occurs among ail the areas of the class-size.

The difficulty with this method, noted in Charles M. Tlebout, The Community Economic Base Study (New York: Committee for Economic Development, 1962), p. 50, is where cne establishes the minimum employment requirement. "The higher the cutoff place, the less each community will have as exports. Thus unless good judgment is used, this approach can be misieading." 
services, trades, construction, finance, and other industry groups outside the manufacturing sector; howerer, the assumptions, methods, and purposes underlying any of these approximations tended to differ slightly. Therefore different aspects of the economy were measured.

However measured, the changes in the Bay Area during the 1950 's were great. Growth was the key in this region as in the state. 49 A rapid expansion caused by many interacting forces had led to a major shift in relative importance of broad industry groups. The state's manufacturing output grew faster than the nation's, and business prospects looked better in many aspects. In all editions of the San Franclsco Chamber of Commerce's annual publication concernIng the region's economy between 1950 and 1960, growth potential and business outlook were praised. It was continually suggested that the boom would certainly extend through 1970.50

The future of the electronics and aerospace industry looked particularly good in the area. James Black, president of Pacific Gas and Electric Company, had suggested as early as 1955 that the state had no major Industrial problems confronting it. He also noted that no defense cutbacks

49A good summary of state growth is found in Sidney Sonenblum, "Economic Projections for California in 1975," in Hirsch and Baisden, California's Future, pp. 13-14.

p. 5 .

50 San Franc1sco and the Bay Area (1950-1950 issues), 
were Iikely to occur, thus feopardizing the aerospace industries. Dr. Arnold Beckman, president of Beckman Instrument Company, stated at the same time that the electronics Industry would, perhaps, accelerate its expansion. Its leveling off place would be years ahead. 51 By 1960, these dreams seemed to have become reality, and similar prophecies for later years were offered. The Bay Area Real Estate Report noted that ". . the electronics industry has been - . most beneficial to the Bay Area." Continued growth, the author said, could certainly be expected. 52 Finally, a Santa Clara County Planning Department analysis of the county and surrounding communities for 1960 noted that the bay region would continue to be a cultural, financial, tourist, heavy inaustrial, transport, and high value industrial center. Only for Santa clara County did the decade appear to end on a diminished note. "Ample employment opportunities in diversified industries," stated the Planning Department report, "will be needed if our future population is to Iive in prosperity. "53 What, Indeed, had occurred to stifle the otherwise glowing future of the area? Perhaps this warning was mere cautiousness. Or did it foretell real dangers for the Bay Area economy?

51 "Business Leaders Find Outlook Bright for 1955," Fortnight, January 5, 1955, pp. 11-12.

52C. D. Lafferty, "Industrtal Development "1rends," Bay Area Real Estate Report (4th quarter, 1959), 85.

53 Facts and Forecasts, pp. 24 and 34. 
IV. THE SURGE OF AEROSPACE

The decade of the fifties had ended, but growth was not to cease. The factors leading to California's growth durling the 1940's and 1950's--good climate, abundance of resources, and general high levels of economic activity-would continue during the coming decade. These factors, according to James Gillies of the University of California at Los Angeles, would be the main forces creating future expansion. I However, another force underlying the state's and the Bay Area's prosperity was becoming increasingly evident. The new levels of defense spending attained by the federal government had provided great stimulus to California growth. Its impact, according to a significant state report, had brought major changes to the economy. Urban growth had been abnormally high, the agricultural industry had suffered heavy losses, and much higher wages and salary levels had been prompted by the high-skilled labor requirements of new industry. "It is apparent," the report noted, "that much of California's most rapid growth was stimulated by economic factors that ultimately were a

ICalifornia, Governor's Commission on Metropolitan Area Problems, Metropolitan California, edited by Ernest A. Engelbert (Sacramento, 1901), p. 9 (Hereinafter referred to as Metropolitan California). 
part of a larger national defense procurement policy. . . [Furthermore] economic investments in defense-oriented industries will continue to guide the volume and direction of new development in the State's metropolitan areas."2 Indeed, the growth did continue, and it was more and more evident that national defense pollcy was very important to that growth.

The population explosion, which had been so large during the 1950's, did not diminish during the 1960's. DurIng the first half of the new decade the state's population grew 3,338,000--about 20 percent. The Bay Area's increase, a sizable portion of the state growth, was $719,800--a 1 s 0$ about 20 percent. 3 The local San Jose area newspaper reported that apartments covered once prosperois orchard land, and the most frequent vehicle seen on the city streets besides the passenger car was the moving van. The apartment boom, it observed, was synonymous with the establishment of Lockheed Missiles and Space Company, IBM, and Ford Motor Company in the area. 4 Such growth naturally prompted increases in employment, construction, and retail sales; and since much of this growth was prompted by the more highly paid aerospace industry, income and buying power rose.

2Phase II Report, p. 39.

3Supra, Table 12, p. 58.

4Mercury, January 10 and 17, 1956. 
Bay Area employment easily reflected the continued expansion of the region. Manufacturing enlarged its employment over 100,000 during the first half of the sixtles, and the nonmanufacturing sectors gained about 250,000 employees. The San Jose SMSA st1II accounted for a large portion of this growth. Since it accounted for some 30 percent of the Bay Area's population growth, it is not surprising that its growth in employment totaled almost 30 percent of the larger region's increase. Nonmanufacturing employment increases dominated the Bay Area growth during these years; however, manufacturing industries failed to increase at the rate they had during the previous decade. The 20 percent growth of the 1950 's was more than halved during the first flve years of the 1960's. In the Santa Clara Valley manufacturing employment growth remained higher, at 23 percent; but, even here, the great increases of the late 1950's were not to be matched. A leveling off point was clearly reached. Manufacturing had reached a stage in the Santa Clara Valley where 1t was, according to a 1964 report by the Bank of America, ". . the largest single contributor to the county's growth." 5 In the Bay Area, it had certainly reached a position of heavy economic impact. It seemed that the nonmanufacturlng sectors of the economy had finally matched the manufacturing sectors.

5Focus on Santa Clara County, 1964, p. 7 . 
Even though the higher than 30 percent growth rate of the 1950's was not continued in the nonmanufacturing Industries of the Bay Area, the sixties fostered a continued hlgh expansion rate (see Table 14). Only in the construction industry did a retraction of growth occur, and this may have been caused by the tremendous inflationary trend and recession of the mid-1960's. Despite the drop-off in employment in the industry during 1965, bullders had constructed 260,265 private dwellings between January, 1961 and December, 1965. A total of 71,959 more houses were constructed than had gone up during the period between January, 1956 and December, 1960. The San Jose SMSA still led the Industry, even holding a 20 percent growth figure in 1965. Its bullders were responsible for 31 percent of the private Qwelings constructed during the period, slightly leading the Alameda county portion of this construction; and valley builders received a large share of the $\$ 236,812,736$ spent by industries, which constructed and expanded 687 plants during these years. 6

The other nonmanufacturing industries in Santa Clara Valjey also led the overall growth of the Bay Area. The services industry, in front of other nonmanufactiring sectors, increased 64.4 percent in the entire Bay Area and 256.9 percent in the Santa Clara Valley. Business services,

6 Abstract, 1968, p. 142; and Data Sheet. 
TABLE 14

NONMANUFACTURING EMPLOYMENT INCFEASE

IN THE BAY AREA, 1960 - 1965

\begin{tabular}{|c|c|c|c|}
\hline Bay Az'ea & 1960 & $1965^{*}$ & $\not$ \\
\hline 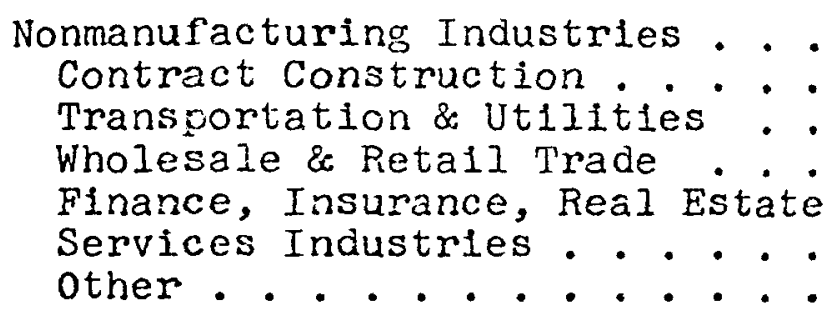 & $\begin{array}{r}647,397 \\
78,725 \\
99,181 \\
250,790 \\
73,655 \\
133,370 \\
5,676\end{array}$ & $\begin{array}{r}800,700 \\
78,400 \\
120,900 \\
289,800 \\
90,300 \\
219,200 \\
2,100\end{array}$ & $\begin{array}{l}24.8 \\
-- \\
21.8 \\
15.5 \\
22.6 \\
64.4 \\
--\end{array}$ \\
\hline Manufacturing Industries & 277,592 & 288,900 & 4. \\
\hline San Jose SMSA & 1960 & 1965 & $\%$ \\
\hline 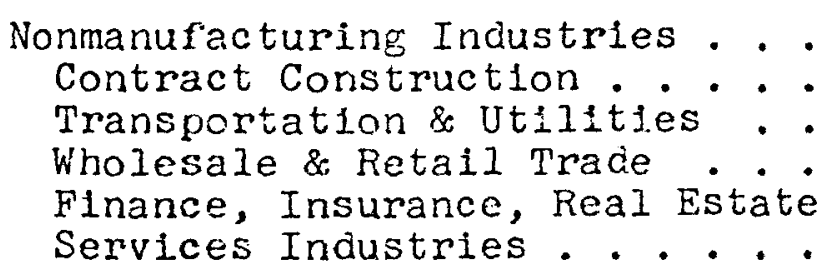 & $\begin{array}{r}85,710 \\
16,278 \\
8,316 \\
34,275 \\
6,417 \\
19,545\end{array}$ & $\begin{array}{r}140,900 \\
19,900 \\
12,200 \\
48,900 \\
9,700 \\
50,100\end{array}$ & $\begin{array}{r}64.4 \\
22.7 \\
46.9 \\
42.9 \\
51.5 \\
156.9\end{array}$ \\
\hline anuracturing Industries & 73,046 & 90,000 & 23. \\
\hline
\end{tabular}

* Figures for 1965 are from the California Labor Statistics Bulletin for July, 1965. Because of the interim nature of this pubication, the data are not completely rellable and must serve only as an estimate.

Source: Infra, Table B, Appendlx II, p. 196.

It might be noted, were highly significant in making such expansion possible. It is important to realize that almost all research and development ( $R$ \& $D$ ) firms were classified as service industries, and this may well account for a large portion of the sector's growth.7

7Bank of America National Trust and Savings Association, Focus on San Francisco-Oakland Metropolitan Area: An 
Reflecting the general upward trend of the economy, Bay Area retali sales increased about $\$ 1.5$ bfllion during the first half of the 1960 's, reaching $\$ 6,588,554,000$ in 1965. Santa Clara County's share of the growth was substantial, too, as retall sales increased $\$ 537$ million, reaching a 1965 total of $\$ 1,458,288,000--22$ percent of the Bay Area figure. 8 No coubt prompting this growth was the rise in total personal income and buying power. In 1961, Bay Area residents took home $\$ 10.9$ billion and, in 1965 , $\$ 14.6$ billion. Those persons living in the San Jose SilSA accounted for 17.2 percent of the income in 1961 and 19.6 percent of it in 1965.9 Net buying power mirrored the income increase, growing from $\$ 8,107$ to $\$ 9,386$ per household and from $\$ 2,496$ to $\$ 2,911$ per capita between 1961 and 1965 . In Santa Clara County, the household and per capita net buying power grew at the same rate, increasing $\$ 1,184$ and $\$ 374$ respectively. While this area's per capita buying power remained below the Bay Area's average, its household buying power now exceeded the Bay Area average during these years. 10

Economic Study Prepared by Bank of America N.T. \& S.A. (San Francisco, 1967), p. 4 (Hereinaiter referred to as Focus on San Francisco-Oakland).

8 Data Sheet; Sales Management, May 10, 1961, p. 382; and Sales Management, June 10, 1966, p. C-15.

9 Abstract, 1968, p. 55.

10Sales Management, June 10, 1962, p. 609; and Sales Management, June 10, 1966, p. C-17. 
The overall economy of the Bay Area had reached a truly prosperous level by the early sixties, and the very rapid expansion of the aerospace industries--over 200 percent according to one sourcell--was undoubtedly a key factor in the attainment of such a prosperous economic state. The Cold War, Korean War, and Vietnam War had fostered large United States security programs. Except for temporary, brief thaws during 1957-58 and 1963-64, defense spending continued at high levels.12 Coupled with the establishment of NASA in 1958 and President John F. Kennedy's top priority order for the Apollo moon project in 1961, defense spending had a most important impact on the California and Bay Area aerospace industry. The faclities in California were readily adapted to both defense and space programs. The aerospace Industry grew quickly when NASA contracts were added to the large quantity of defense contracts already being let to California firms. 13

IlFobert K. Arnold, et. al., The California Economy, 1947-1980 (Menlo Park, Callfornia: Stanford Research Institute, 1960$)$, p. 118.

12 Murray $L$. Weidenbaum, "Impact of the Vietnam War on the American Economy" in, U.S., Congress, Joint Economic Committee, Economic Effect of Vietnam Spending, Hearings, before the Joint Economic Committee, 90th Cong., lst sess., $1967, I, p .194$, contains a good discussion of the growth and levels of U.S. Cefense spending during the 1950's and 1960 's.

13 California, Governor, Economic Report of the Governor, 1968 (Sacramento, February, 1968), p. 30 (Hereinafter referred to as Report of the Governor, 1968); and United 
The electronics and related industries, so closely tied to the prime aerospace companies that thay may well be classified aerospace themselves, became more nearly dominant In the Bay Area than anywhere else in the nation. 14 In a study executed by Santa Clara County in 1967, the south bay region economy was measured in two ways. "Both approaches-the 'shift' analysis ard the 'minimum requirements' approach --taken together indjcate that overall county growth as measured by employmert trends, has centered around the defense-space sector...." The report stated that the area was becoming more and more economically unbalanced. 15 The Bay Area became one of the most important national regions in the production of highly technical aerospaceelectronics equipment for the Defense Department and NASA. Durable goods, 51 percent of total manufacturing in the south bay region in 1940, were produced by 85 percent of the area's manufacturing firms by 1963. A Bank of America study in

California Bank, Research and Planning Department, 1969 Forecast (Los Angeles, 1968), p. 46.

14Frank H. Stedman, "The California Penirisula: Laboratory of the New Industrial Age," Industrial Develooment and Manufacturers Record, October, $1953, \mathrm{p} .35$.

15Economy of Santa Clara County, p. 13. The "shift analysis" studies the growth of an area from three points of view. First, the area's growth rate is compared to that of the national economy. Secondly, growth is analyzed in terms of the number of fast and slow growing industries in the area. Finaliy, growth is analyzed in terms of the growth rate of individual industries in the area compared to the national growth rate of the same industries. An explanation of the "minimum requirements" approach is found in supra, p. 68, n. 48 . 
1964 reported: "Within durable manufacturing, it was the activities associated with defense-space equinment, largely electrical machinery (electronics) and ordnance (missiles), which set the pace."16 In 1950, only 13 percent of total south Bay Area manufacturing employment was in this category; by 1969 , the share was approximately 60 percent. Nearly 70 percent of all new manufacturing jobs since 1950 were In these industries. 17 The growth prompted by the influx of aerospace industries was quite similar to that experienced in Southern California during the 1950's. "Unlike the southern region, however, there [was] no declining aircraft industry in the bay region to inhibit the growth in the 1960's."18

16 Focus on Santa Clara County, 1964, p. 7; see also, Focus on san Francisco-0akland, pp. 49-50. So closely connected have been the defense and space efforts, one political scientist has suggested that the space race may be or easily become the cold war in orbit. See Amitai Etzioni, The Moondoggle: Domestic and International Implications of the Space Race (Garden City, New York: Doubleday \& Co., 1964), pp. 114-148, passim. While this may be an overstatement, a large, untold amount of the space effort is military controlled and oriented. Consequentially, the space industry is considered to be a part of defense-related industries by the author.

17Bank of America National Trust and Savings Assoc1ation, Focus on Santa Clara County, An Economic Study Prepared by Bank of America N.T. \& S.A. (San Francisco, 1969) Focus on Santa Clara County, $1964, \mathrm{p}$. 7 , states that 80 percent of the manufacturing jobs added to the county between 1955 and 1.963 were in electronics and missiles.

18 Arnold, California Economy, p. I18. 
It seemed that the Bay Area, particularly the Santa clara Valley, was becoming overly dependent unon the defenserelated industry. Yet, some authorities suggested that, during this period, the dependency on defense-oriented industries had been over-publicized. A study by Crocker Citizen's National Bank stated: "While heavily Involved in defense-related work, Calffornia had a very broad and remarkably varied economic base."19 Although its pattern was different from the nation as a whole, suggested another source, the Bay Area's economy was well-balanced and not dependent upon one dominant Inoustry. 20 Still the Bank of America suggested that ". . . because the Bay Area does not rely heavily on any single industry, its economy has a stability enjoyed by few areas of comparable size anywhere in the nation." No single nor simple cause for the region's economic expansion, it continued, could be cited. 21 Nonetheless, defense-related industry was important--very important --to the state and bay region, and many sources recognized this trend. The industry's growth in the early sixties, according to Federal Reserve authorities in San Francisco,

\footnotetext{
19Crocker Citizen's National Bank, Callfornia Economic Diversity (San Francisco, [1964]), unpaginated. p. 44.

20 Bay Area Council, Guide to Industrial Locations,

21 Focus on San Franclsco-Oakland, pp. 1 and 3. This source also expresses the view that the Bay Area is one of the most important areas in the nation for the production of aerospace-electronics equipment. Supra, n. 17, p. 80.
} 
added significantly to the economic expansion of the entire West; and locally, the San Jose newspaper noted that increases in missile production would have a great effect on the Pacific coast.22 In the San Jose SMSA, the impact could not be denied, for over $\$ 384$ milison were paid to defense-related industry workers in 1962, compared to less than $\$ 30$ milizion in 1952.23

The impact of the defense-oriented industries on the Bay Area economy was rarely disputed. However, the impact was little understood, and rarely was its magnitude comprehended. Perhaps one of the best general indicators of the emergence of a dominant aerospace industry in the area during the $1960^{\prime} \mathrm{s}$ was seen in a consideration of the export sector of the regional economy. "Uncle Sam," reported the San Jose News on March 11, 1968, "is Santa Clara Valley's biggest customer." The area, it continued, is influenced by external forces over which the local economy has no control-forces such as the national economy and the level of defense expenditures. 24 Nost of the manufacturing firms of the Bay Area tended to produce for markets outside the area--export markets. As noted in Chapter III, the 1959 export

Review, harch, $1963, \mathrm{p} .45 ;$ and News, May $8,1962$.

23 Focus on Santa Clara County, 1964, p. 7.

24 See also, Economy of Santa Clara County, pp. 16-17.


manufacturing activity of the area fluctuated somewhere between 40 and 65 percent. 25 Such activity was commonly referred to as "basic"; for $1 t$ brought in capital from the outside which, by circulating within the local region, provided the primary income of the area. The south bay region, in particular, had felt the emergence of the aerospace industry. During the 1960's it accounted for as much as 10 percent of the area's employment. In 1965, for example, a 54,000 out of 90,000 manufacturing positions were in aerospace f1rms; and since the buIk of the industry leans towards the federal government for production orders, 1t was a primarily basic industry. 26 A recent report by the Bank of America suggested that approximately 70 percent or the aerospace industry served the federal government-52 percent to the Department of Defense, 10 percent to NASA. and elght percent to other agencies. The remaining 30 percent, it suggested, went to civilian markets. Although the report did not indicate to what final market this civilian percentage went, a considerable proportion might have gone Into the federal Government market. 27 If the export percentage of the reglon's manufacturing market was 60 percent, and 50 percent of the manufacturing employment was in

25 Supre, pp. 65-67.

26 Economy of Santa Clara County, pp. 10-11 and 16; and News, March 9 and $11,1908$.

27 Focus on Santa Clara County, 1969, p. 4. 
aerospace in 1965, then a rough estimate would suggest that 36 percent of the region's basic economic activity was a result of derense-oriented industries. Since at least 70 percent of the aerospace market is with the federal government--an export market--25 percent of the basic activity of the south bay region might well be attributed to the federal government. Furthermore, one may suggest that 22 percent of this activity was directly accounted for by the Department of Defense and NASA. More will be related about such estinates in succeeding chapters. It is enough to note that the aerospace industry had certainly reached a level of major importance to the south Bay Area, indeed the whole Bay Area, by the 1960's. So Important was the new Industry, In fact, one may safely suggest the Bay Area was to an undesirabie extent dependent upon $i t$.

The large companies of the area--Lockineed Missiles and Space, IBM, Hewlett-Packard, and others--had by 1965 reached a point of relative maturity. Smaller companies, though still springing up, were in a perlod of consolidation. The community became aware of the aerospace industrial complex and, perhaps, some of the implications of the industry to the area's well-being. The growth of the aerospace Industry in the Santa Clara Valiey was so fantastic that the northern part of Santa Clara County was becoming less and less an Identifiable community. An increasing number of the area's workers came from outslde the north county, and each 
small town grew so quickly that they all seemed to blend together. 28 The growth was recognized as being dependent largely upon defense spending, and it was probably pleasing to hear the San Franclsco branch of Arthur D. Little, Inc., predict that funds spent on missiles would not drop off until at least the seventies. 29 By 1966, the Mountain View and Sunnyvale areas housed over 130 industries, which were primarliy in the electronics field; the United States Naval Air Station and NASA's Ames Research Laboratories at Moffett Field tozether provided about 6,900 jobs in the two communities. 30

Palo Alto seemed to be the center of the aerospace Industrial complex. Bright young men from Stanford Jntversity, particularly, appeared to have ". . created a city within a city. Four firms alone--Lockheed, Philco, Varian, and Hewlett-Packard--[accourted for] a \$104 mililon payroll annually."3I Lockheed Missiles and Space Company, dominating this growth, was the builder of the Discoverer Sateliite and the Polaris missile series. One out of every fifteen employees in Santa Clara County, it was suggested, worked directly for Lockheed. So great was the aerospace impact,

$$
\begin{aligned}
& \text { 28 Mercury, May 19, } 1964 . \\
& \text { 29 Mercury, June 17, } 1964 . \\
& \text { 30 Mercury, January 17, } 1966 . \\
& 31_{\text {Mercury }} \text { January 10, } 1966 .
\end{aligned}
$$


that some people feared the area might become another San Diego, which had suffered greatly when defense contracts to that area were cut sharply in the early sixties. Even a gradual reduction in defense funds entering the valley was cause for concern, for doubt existed that defenseorlented firms could successfully make the transition to production of consumer and industrial products. A report of the Santa Clara County Planning Department stated that the ". . dependence of the economy on the aerospace industries, . . the reliance of the aerospace complex on a single market, and the dominatior by a few major firms [made] the local economy extremely sensitive and vilnerable to external events and decisions..."32 Even San Mateo County's growing complex of manufacturers, wholesalers, and service flrms seemed endangered; for they had located there, In part, as a natural overflow from the northern Santa Clara aerospace complex. 33

Throughout the rest of the Bay Area, little concern over defense-orlented industrial growth was shown. The San Francisco-0akland metropolftan area was characterized as the West's financial capital, and defense-spending was largely 1gnored as an endangering factor in the economy. It was noted, however, that the East Bay region--primarily Alameda

32 Background: Santa Clara County, pp. 3-5; see also Economy of Santa Clara County, p. 12 . 33Focus on San Franc1sco-0akland, pp. 45-46. 
County-held a disproportionate share of government employment as a result of its several military estahlishments. Also the University of California was observed to have attracted more than its share of federal research funds which, according to the Bank of America, ". . In turn, spurred the establishment of nuclear and electronics research facilities in the area." 34 Even so, most of the area's manufacturing employment was considered, in 1967, to be other than defense-oriented. The food processing industry. remained the leader. 35

The fact that defense incustries had become important, though, was not totally disregarded at all times. During 1964, the Bay Area felt the effects of cutbacks in spending and recognized that serious repercussions could result. A drop in activity in the aerospace industry was obvious to local observers. A county research progran in the Santa Clara Valley prompted less than optimistic comments about the area's economic future. Noting the importance of the aerospace industry, it was observed in January

34Ibid., p. 15 and 27-28. The impact of military bases in the area was noted, but it was not considered cruc1al. Bay Area Counc1l, Cuide to Industr1al Locations, p. 3, suggested that the Unlversity of California in Berkeley and the Atomic Energy Commission Laboratory in Livermore were the nuciel of these East Bay facilities.

$35 \mathrm{California,} \mathrm{Department} \mathrm{of} \mathrm{Employment,} \mathrm{Research} \mathrm{and}$ Statistics Section, East Bay Manpower Survey, Alameda County, 1966-71 (San Francisco, 1967), p. 8. 
that the region's economy might well be unbalanced. "Such a circumstance holds the threat of widespread unemployment," stated the local newspaper, ". . If defense contracts are curtailed." While serlous cutbacks were not foreseen, the press added that the fate of much of the area's population rested with the aerospace industry. Even a temporary employment loss could still seriously disrupt the area. 36 The pessimism shown in January, however, was tempered by the end of the year, and the aerospace industry was suggested to be merely leveling off. In fact, new contracts were expected in the future to provide more growth. 37

By the end of the sixties, the fliture of the aerospace industry was again bright. Plant expansions were once again announced and employment growth c1ted. Private studies again began to forecast continued growth in the region of defense-orlented Industries, for military spending was expected to continue. 38 Fear over the dependency level of the state was now becoming more widespread, however, and concern was shown over diversification efforts of aerospace

36 Mercury, January 15, 1964.

37 Mercury, october 26, 1964, citing a study by the Bank of America. See also Mercury, october 27, 1964.

38 Goldberg and Walter, "Forecasting Employment," p. 15. See also Christian Science Monitor, January 8, 1969; and Mercury, september 19 and November $8,1967$. 
89

firms. 39 Yer the vital character of the industry to the economy of California and the Bay Area seemec to remain relatively unnoticed.

39Engineering Employment, p. 28; and United Cal1fornia Bank, 1969 Forecast, pp. 43 and 45 . 


\section{MEASURING THE IMPACT OF DEFENSE SPENDING ON AREA GROWTH}

On July 20, 1969, the Unfted States accomplished a seemingly Impossible feat. The combination of money, technology, and faith had combined together to land a man on the moon. The accomplishment was remarkable. Its possible ramifications are yet untold. Interestingly, the crew of Apollo 11 was not the one originally scheauled for the fllght. Removed from the flight only weeks before the launch was the all military crew which later made the Apollo 12. flight in November, 2969. Replacing the original crew was a back-up crew led by a clvilian. A major attempt had been made to illustrate that America's space program was not tied in with her military efforts. The first man on the moon was a civilian. Yet the relationship of the two programs was evident. The expenditures of NASA were certainly related to defense spending, and in California both these expenditures were large.

The Apollo 11 program cost America approximately $\$ 24$ billion dollars over a period of elght years, and each state in the Union was awarded at least $\$ 25,000$ of this space expenditure. Western states recelved about 44 percent of the total amount, and California's share was approximately 
41 percent of $\$ 9.9$ bililon. An average annual NASA income of some $\$ 1.2$ blizion for California between 1961 and 1969 made a sizable impact upon the state's way of Iife. 1

It seems evident that defense and space spending have left a deep Imprint on the growth and quality of life in California. True, since the early 1900's California had experienced broad-based industrial growth, as suggested by an economist for the Bank of America; but most marketing specialists seemed overly concerned with the breadth of the state economy and overlooked its narrow mainspring-alrcraft and related industries which were quite dependent on federal spending. Perhaps it was not mere coincidence that the state's outburst of growth in the 1940's began at the same time federal spending was enlarged in the regton. Nor was it chance that postwar reductions in spending and growth colncided or that since 1950 Callfornia had enjoyed both favorable growth and enlarged federal spending. ${ }^{2}$ Evidence certainly indicated that profits were at least as high in defense as in commerclally oriented industries. In fact, statistics presented by economist Murray L. Weidenbaum of Washington University showed the defense industry profits

IChristian Science Monitor, May 28, 1969, p. 7.

2sterling L. Brubaker, "The Impact of Federal Government Activities on California's Growth, 1930-1956" (unpublished Ph.D. dissertation, University of California, Berkeley, 1959), pp. 8 and 77 . 
considerably higher than those of commerclally oriented industry. The net profits of stockholders' investments between 1952 and 1955 were 18.6 percent in defense and 13.0 percent in non-defense industries. Of course, this was a period of overall economic expansion in the nation. Between 1962 and 1965, years when the defense industry suffered some major contract cancellations and stretch-outs, the margln was even greater, being 17.5 percent in defense and 10.6 percent in nondefense industries. 3 If these are reliable figures, one can easily judge that the growth rate of California's defense-orlented Industries since the Second World War had added significantly to the state's overall growth. The high profits no doubt resulted in many residual economic benefits to the region. James L. Clayton, professor of history at the University of Utah, has conclucied that ". . It is entirely possible that defense spending will loom as the single most important economic and demographic factor in the history of the Far West during the past two decades. " 4

Measuring the impact of defense-related spending at

3U.S., Congress, Joint Economic Committee, Economics of Military Procurement, Hearings, before the Subcomittee on Economy in Government of the Joint Economic Committee, 90th Cong., 2d sess., 1969, Pt. I, pp. 57-58.

4 James L. Clayton, "The Impact of the Cold War on the Economies of California and Utan, 1946-1965," Paciflc Historical Review, XXXVI (November, ig67), 473. 
the state level was possible, for data was available. 5 The direct military impact on the state was rather obvious but probably overrated. A review of the numbers of military personnel and civilian employees of the military sectors of the federal government in California revealed the impact. During the Second World War as many as 936,000 military personnel were in the state; then after a decline in the late 1940 's to 160,000 , the number grew during the Korean conflict and leveled off at slightly over 330,000 through the 1950 's (Table 15). In 1960 the number of personnel had aropped off to around 304,000. Three years later, in 1963, the number had increased again to about 333,000. Civilian employees of the military sectors of federal employment in Californta had added an average of another 150,000 employees to the total military employment of the state since World War Two. Evidence of the impact of these numbers in simple economic terms was seen in the estimated payrolls of these military and civilian personnel (Table 16). In 1962, for example, the some 317,000 military personnel in California received approximately $\$ 1.3$ billion in pay and allowances. When one added civilian employment of the military sectors In Callfornia, the figures increased substantially--in 1962 ,

5References to impact on the state will be made throughout this chapter. Ib1d., pp. 449-73, passim, presents the most complete overali analys is of the historical impact of defense spending on California's economy seen by this writer. Yet, Clayton's work is by no means definitive. 
TABLE 15

CALIFORNIA MILITARY STRENGTH AND FEDERAL CIVILIAN EMPLOYMENT

(In thousands)

\begin{tabular}{|c|c|c|c|c|c|}
\hline \multirow[b]{2}{*}{ Year } & \multirow[b]{2}{*}{ M1I1tary } & \multicolumn{3}{|c|}{ CIVIIIan } & \multirow[b]{2}{*}{ Total } \\
\hline & & MIIItary & NACA/NASA & Total* & \\
\hline $\begin{array}{l}1940 \\
1941 \\
1942 \\
1943 \\
1944 \\
1945\end{array}$ & $\begin{array}{r}51 \\
188 \\
438 \\
936 \\
862 \\
821\end{array}$ & $\begin{array}{r}20 \\
39 \\
120 \\
200 \\
230 \\
254\end{array}$ & $\begin{array}{l}-- \\
-- \\
-- \\
-- \\
-- \\
--\end{array}$ & $\begin{array}{r}20.0 \\
39.0 \\
120.0 \\
200.0 \\
230.0 \\
254.0\end{array}$ & $\begin{array}{r}71.0 \\
227.0 \\
558.0 \\
1136.0 \\
1092.0 \\
1075.0\end{array}$ \\
\hline $\begin{array}{l}1946 \\
1947 \\
1948 \\
1949 \\
1950\end{array}$ & $\begin{array}{l}261 \\
160 \\
169 \\
176 \\
171\end{array}$ & $\begin{array}{l}131 \\
111 \\
125 \\
104 \\
136\end{array}$ & $\begin{array}{l}.8 \\
1.0 \\
1.0 \\
1.2 \\
1.3\end{array}$ & $\begin{array}{l}131.8 \\
112.0 \\
126.0 \\
105.2 \\
137.3\end{array}$ & $\begin{array}{l}392.8 \\
272.0 \\
295.0 \\
281.2 \\
308.3\end{array}$ \\
\hline $\begin{array}{l}1951 \\
1952 \\
1953 \\
1954 \\
1955\end{array}$ & $\begin{array}{l}376 \\
444 \\
420 \\
340 \\
336\end{array}$ & $\begin{array}{l}177 \\
184 \\
170 \\
152 \\
153\end{array}$ & $\begin{array}{l}1.4 \\
1.4 \\
1.4 \\
1.5 \\
1.6\end{array}$ & $\begin{array}{l}178.4 \\
185.4 \\
171.4 \\
153.5 \\
154.6\end{array}$ & $\begin{array}{l}554.4 \\
629.4 \\
591.4 \\
493.5 \\
490.6\end{array}$ \\
\hline $\begin{array}{l}1956 \\
1957 \\
1958 \\
1959 \\
1960\end{array}$ & $\begin{array}{l}334 \\
329 \\
331 \\
321 \\
309\end{array}$ & $\begin{array}{r}152 \\
-- \\
-- \\
-- \\
--\end{array}$ & $\begin{array}{c}1.7 \\
-- \\
-- \\
-- \\
--\end{array}$ & $\begin{array}{l}153.7 \\
151.5 \\
155.2 \\
157.5 \\
158.3\end{array}$ & $\begin{array}{l}487.7 \\
480.5 \\
486.2 \\
478.5 \\
467.3\end{array}$ \\
\hline $\begin{array}{l}1961 \\
1962 \\
1963 \\
1964 \\
1965\end{array}$ & $\begin{array}{l}304 \\
317 \\
333 \\
320 \\
309\end{array}$ & $\begin{array}{l}-- \\
-- \\
-- \\
-- \\
--\end{array}$ & $\begin{array}{l}-- \\
-- \\
-- \\
-- \\
--\end{array}$ & $\begin{array}{l}163.0 \\
166.0 \\
164.8 \\
165.0 \\
167.4\end{array}$ & $\begin{array}{l}467.0 \\
483.0 \\
497.8 \\
485.0 \\
476.4\end{array}$ \\
\hline
\end{tabular}
tion reports.

*1957-1965 estimated by author from current popula-

$\begin{aligned} & \text { Sources: Compiled from Robert K. Arnold, et al } \text { The } \\ & \text { Californta Economy, } 1947-1980 \text { (Menlo Park, }\end{aligned}$ California Economy, $1947-1980$ (Menlo Park, Table XII-3, p. 365; Sterling L. Brubaker, "The Impact of Federal Government Activities on

California's Economic Growtn, 1930-1956" 
(unpublished Ph.D. dissertation, University of California, Berkeley, 1959), pp. 336-37; Bank of America, Economics Department, Significance of Military Installations for California's Economic Growth, 1930-1952, by Sterilng L. Brubaker (San Francisco, 1955), Table 5, p. 10; U.S., Department of Commerce, Bureau of the Census, Current Population Reports: Ponulation Estimates, Series P-25, Nos. 229 and 324 (Washington, D.C.: Government Printing office, January 20 and May 22, 1966), pp. 4-7 and 12-14.

by $\$ 975$ militon. Thus the combined civilian and military payrolls reached $\$ 2.3$ million--perhaps 4.7 percent of the total personal income of the state. ${ }^{6}$ This percentage was not large and probably not very significant in terms of the overall state economy. The military would probably not be a large factor in ruture state growth, for no recurrence of the growth seen during Norld War Two was in the foreseeable future. Conversely, no sudden decline in the military would

6U.S., Congress, Jo1nt Economic Committee, Background Material on Economic Aspects of Military Procurement and Supply, 88th Cong., Ist sess., March, 1963, pp. 4-5, presents Plgures of considerable varlance for 1962 to those shown in Table 16, this paper. Military pay and allowances in the state are shown to be $\$ 842,670,000$ and civilian employee payrolls to be $\$ 866,915,000--a$ total of $\$ 1,709,585,000$. The discrepancy of some $\$ 574$ million between these sources is significant; nowever, the Background Material data is only presented for one year. Accoraing to Bank of America, Economics Department, Signiflcance of Military Installations for California's Economic Growth, 1930-1952, by Sterijing L. Brubaker (San prancisco, 1955), p. 19, the addition of indirect effects of greater civiliar employmert and business opportunities as a result of the presence of military installations and personnel might substantially raise the percentage of personal income resulting from direct military involvement in the state. 
TABLE 16

ESTIMATED ANNUAL DEPARTMENT OF DEFENSE MILITARY AND CIVILIAN PAYROLLS IN CALIRORNIA AS A PERCENTAGE OF PERSONAL INCOME, 1946-1965 (In millions of dollars)

\begin{tabular}{|c|c|c|c|c|c|}
\hline \multirow[b]{2}{*}{ Year } & \multicolumn{3}{|c|}{ Department of Defense } & \multirow{2}{*}{$\begin{array}{c}\bar{B} \\
\text { Personal } \\
\text { Income }\end{array}$} & \multirow{2}{*}{$\begin{array}{ll}\text { Column } & A \\
\text { as a of of } \\
\text { Column } B\end{array}$} \\
\hline & M111tary & Civilian & $\frac{A}{\text { Total }}$ & & \\
\hline $\begin{array}{l}1946 \\
1947 \\
1948 \\
1949 \\
1950\end{array}$ & $\begin{array}{l}830 \\
464 \\
453 \\
463 \\
596\end{array}$ & $\begin{array}{l}358 \\
362 \\
364 \\
401 \\
414\end{array}$ & $\begin{array}{r}1,188 \\
826 \\
817 \\
864 \\
1,010\end{array}$ & $\begin{array}{l}16,048 \\
16,637 \\
17,621 \\
17,866 \\
19,760\end{array}$ & $\begin{array}{l}7.4 \\
4.9 \\
4.6 \\
4.8 \\
5.1\end{array}$ \\
\hline $\begin{array}{l}1951 \\
1952 \\
1953 \\
1954 \\
1955\end{array}$ & $\begin{array}{l}1,016 \\
1,325 \\
1,274 \\
1,113 \\
1,109\end{array}$ & $\begin{array}{l}654 \\
740 \\
724 \\
650 \\
721\end{array}$ & $\begin{array}{l}1,670 \\
2,065 \\
1,998 \\
1,743 \\
1,830\end{array}$ & $\begin{array}{l}22,740 \\
25,196 \\
26,984 \\
27,661 \\
30,356\end{array}$ & $\begin{array}{l}7.3 \\
8.2 \\
7.4 \\
6.3 \\
6.0\end{array}$ \\
\hline $\begin{array}{l}1956 \\
1957 \\
1358 \\
1959 \\
1960\end{array}$ & $\begin{array}{l}1,130 \\
1,112 \\
1,152 \\
1,193 \\
1,220\end{array}$ & $\begin{array}{l}751 \\
764 \\
804 \\
837 \\
862\end{array}$ & $\begin{array}{l}1,881 \\
1,876 \\
1,956 \\
2,030 \\
2,082\end{array}$ & $\begin{array}{l}33,154 \\
35,458 \\
37,339 \\
40,944 \\
42,910\end{array}$ & $\begin{array}{l}5.7 \\
5.3 \\
5.2 \\
4.9 \\
4.8\end{array}$ \\
\hline $\begin{array}{l}1961 \\
1962 \\
1963 \\
1964 \\
1965\end{array}$ & $\begin{array}{l}1,241 \\
1,309 \\
1,351 \\
1,427 \\
1,482\end{array}$ & $\begin{array}{r}922 \\
975 \\
1,01.2 \\
1,071 \\
1,047\end{array}$ & $\begin{array}{l}2,163 \\
2,284 \\
2,363 \\
2,498 \\
2,529\end{array}$ & $\begin{array}{l}45,608 \\
48,980 \\
52,431 \\
56,264 \\
59,476\end{array}$ & $\begin{array}{l}4.7 \\
4.7 \\
4.5 \\
4.4 \\
4.3\end{array}$ \\
\hline Total & 21,260 & 24,433 & 35,693 & 673,454 & 5.3 \\
\hline
\end{tabular}

Source: Calculated from James $i$. Clayton, "The Impact of the Cold War on the Economies of California and Utah, 1946-1965," Pacific Historical Review, XXXVI (November, 1957), Tables I and II, pp. $455-56$. 
I1kely occur in the near future. 7 The San Francisco Bay Area share of this impact was not extremely large, and in any case it would not give much of an indication of the area's defense Industry dependency. Probably the direct impact of the military was relatively minor compared to the impact of defense-related spending to the private sector of the state and Bay Area economies.

According to a State Assembly study, almost twofifths of the nation's defense-space work was done in five major locations in California: the Los Angeles-Long Beach, Sacramento, San Bernardino-Riverside-ontario, San Diego, and San Jose metropolitan areas. The San Francisco-0akland metropolitan area was considered a sixth area of concentration. 8 Each one of these areas, of course, had some influence on the other areas; therefore it became much more difficult to isolate and measure the impact on local areas. For example, a change in defense spending in the Los AngelesLong Beach area would have obvious effects on the economy of that area, but it would also influence the economic iffe elsewhere in the state. "Through traaing relations with

7 Bank of America, Significance of Military Installations, p. 24, suggests that this was also true in 1955.

8 Cal1fornia, Assembly, Interim Committee on Ways and Means, The Impact of Federal Spending in California, Report of the Subcommittee on Economic Development of the Intertm Commlttee on Ways and Means, 1965, p. 12 (Hereinafter referred to as Impact of Federal Spending in California). 
other regions of the State," according to Charles $M$. Tlebout, "they too will feel the impact of the change in defense spending. Thus, such a change will affect employment in San Francisco-0akland, in the rest of the State, and, In turn will have some further repercussions upon employment in Los Angeles itself." 9

Exactly what the Impact was on any certain metropolitan location was most difficult to determine. There were Indications of Impact, but specific statistical evidence was not readily avallable. It was generally agreed that both southern and northern California had their share of defense industries; and, since the former had the most visible defense complex, the San Francisco bay region was generally ignored. Yet, according to the Federal Reserve Bank In San Francisco, northern California was stronger In defense manufacturing during the late fifties than was the southern half of the state. 10 Nonetheless, the Bay Area's defense establishment was for some reason not as vistble as that of the southland. Despite news articles citing that the Lockheed Corporation did some 35 percent of 1 ts business in the bay region ${ }^{12}$ and that approximately

9 Markets for California Products, p. 8.

10"Five Perlods of Growth," Federal Reserve Bank of San Franc1sco: Monthly Review, December, 1965, p. 220.

$11_{\text {Mercury }}$, December 3, 1966. 
$\$ 518$ mililon annually in defense contracts entered the area, 12 studies of the local economy's future rarely made assumptions about defense spending. A recent report by the Stanford Research Institute revealed that only live of twenty-seven Bay Area economic projection studies made any such assumptions. Of these five, three assumed continued high levels of defense spending in the region, one assumed a reduction in constant dollars, and the last assumed both high and low spending in two different projections. 13 Yet the Bay Area, more specifically the San Jose SMSA, produced more than half the nation's integrated circuits--an item vital to computers, missiles, and space satellites--and was ranked tinird in aerospace employment in the state behind southern California complexes. 14 Furthermore, the Bay Area was the headquarters for the San Francisco Defense Contract Administration Services Reglon. Some 865 military and clvilian personnel with offices in Burlingame ran the agency which administered contracts for northern Californla, Utah, Montana, Idaho, Washington, Oregon, Alaska, Hawa11, and most of Nevada. ${ }^{15}$ Additionally, 17 of the state's 78 special

12 News, November $7,1968$.

13 Maurice I. Gershenson, Evaluation of Bay Area Economic Studies: Highlights and Summary (Menlo Park, Cal1fornia: Stanford Research Institute, 1968), p. 14.

14 Economy of Santa Clara County, pp. 17 and 20; and News, March 12, 1968.

15Mercury, December 1, 1965. 
federal agents for small business and labor surplus areas who assisted in obtaining contracts were located in the Bay Area. 16 Certalnly, someone had seen that the bay region had a large defense-space complex.

There were some studies which had probed the degree of the defense-dependency of specific areas. George A. Steiner, for example, completed an excelient study in 1961 concerning the southern California economy's relation to the defense industry, and Charles M. Tiebout conducted a survey of the Los Angeles area's defense dependency in 1964.17 Yet no studies were comprehensive, and these were two of the best. The real problem was that information was not readily avallable, and some was not avaliable at a.ll. According to one federal government commlttee the Department of Defense was gathering new information but much remained to be done. 18 One economist had gone into lengthy dlscussion of this

16U.S., Department of Defense, Sma 11 Business and Labor Surplus Area Specialists Desiznated to Help the Businessman (Washington, D.C.: Government Printing Oírice, 1967), passim.

17Southern California CED Associates, National Defense and Southern Californ1a, 1961-1970, by George A. Steiner (Los Angeles: Southern California CED Associates, December, 1961); and Richard S. Peterson and Charles M. Tiebout, "Measuring the Impact of Regional Defense-Space Expenditures," The Review of Economics and Stat1stics, XLVI (November, 1964 ), 421-28. Perhaps other studies are also out, but they were not found by the author.

18U.S., President's Committee on the Eccnomic Impact of Defense and' Disarmament, Report (Washington, D.C.: Government Printing office, July, 1965$)$, pp. 57-67, passim (Hereinafter referred to as President's Commitiee, Report). 
problem and noted that information concerning defenseoriented netropolitan areas was being collected by the Department of Defense and the Census Bureau, but this data was usually not for public use. According to E. J. Mosbaek, 1t was ". . usually too sensitive for release."19 Murray L. Weidenbaum, a well known national economist, also agreed that there was an unfortunate lack of data; however, he pointed out that the Arms Control and Disarmament Agency and other government departments were beginning to release information. 20 Nonetheless, no reasonable criteria for defining the defense-dependency of an area had been found, and the data to establish such a criteria was either not yet available or collected. Therefore, one could only estimate dependency and assume that these estimates would be substantiated in the future.

There are many approaches one might follow in measuring the impact of defense spending in a region. The impact of a certain type of procurement, such as that for Research and Development, may be investigated. The volume of prime or initial contracts to an area may be analyzed. The quantity of subcontracts (contracts from one company

$19 \mathrm{E}$. J. Mosbaek, "Information on the Impact of Reductions in Defense Expenditures on the Economy," The Quarterly Review of Economics and Business, V (Fail, 1965), 51 and 65 .

20 "Measurements of the Economic Impact of Defense and Space Prograns," The American Journal of Economics and Soclology, XXV (october, 1950), 415-26, passim. 
to another to work on a prime contract held by the first company) entering a region's industrial firms might be calculated and analyzed. The impact of procurement on Industrial groups or specific industries might be studied, or the impact of procurement on the incomes of specific companies may be analyzed. Using data gathered from contract awards, further analysis may be made concerning the exogenous income and the employment of a region. From such analysis perhaps reasonably sound estimates may be made concerning defense impact and dependency.

Since the outbreak of the Korean war the defense budget of the United States had averaged about $\$ 42.6$ b1111on per year, actual calendar year expenditures averaged slightiy more per year at $\$ 42.9$ blilion, and national security expenditures, including both primary defense and space expenditures, averaged approximately $\$ 53.0$ bilition per year. ${ }^{21}$ Approximately 8.6 percent of the annual defense

${ }^{21}$ Calculated from infra, Table D, Appendix I, p. 192. Averages do not include data for 1950, as the Korean War expenditures did not become important until well into that year. The average for national security expenditures was calculated from columns II and III of the referenced table. The variance of data between columns II, III, and IV is probably attributable to rounding off of figures by the original compilers. The variance between column I data and that of the other columns is unclear. Apparently the Bureau of the census had a different criteria for national security expenditures; however, exactly what made up this criterla was not spelied out in the sources consulted by the author. With the exception of data for 1963, 2964, and 1965 whlch is not drawn from the Bureau of the Census the variance is large only in 1951 and 1954. Otherwise, the inconsistencies are relatively small and not considered of consequence. 
expenditure (Department of Defense) had gone into the research, development, test, and evaluation program (RDT \& $E$ or $R \& D)$. This equaled an average of about $\$ 3.6$ billion of annual defense expenditures. Of course, much of the annual defense spending went toward payrolis and allowances, maintenance and operations, military assistance, and other miscellaneous programs. The remainder of the nation's defense expenditures went into military procurement and $\mathrm{R}$ \& D--approximately $\$ 16.8$ billion (average) per year since 1951,22 or 39.1 percent of the $\$ 42.9$ average annual Department of Defense (DOD) expenditures. It was this procurement figure which most directly affected American manufacturing industry.23 of the procurement average of $\$ 16.8$ bilition, 21.4 percent went to $R \& D$. Hence, expenditures for research, development, testing, and evaluation of new weapons, equipment, and other military activities constituted a sizeable portion of the funds directly affecting the country's manufacturing industries.

$R$ \& $D$ expenditures have had an extensive impact on Californta in relation to other areas of the nation. From 1961 to 1965 , a total of slightly over $\$ 11.2$ billion in

22Calculated from infra, Table E, Appendix I, p. 193.

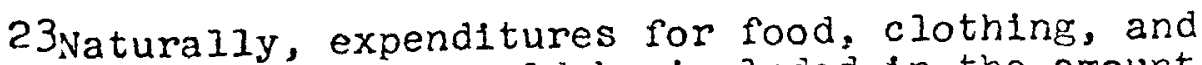
perhaps replacement parts would be included in the amount of the defense budget committed to operations and maintenance, and this, too, affects many of the nation's industrial groups. 
$R$ \& $D$ contracts was given to firms in California. The average for this five year perlod of $\$ 2.2$ billion was not met in 1965 when contracts to the state totaled about $\$ 1.5$ bililon; however, by 1967 the figure had increased to just uncer $\$ 2.0$ billion. While national $R$ \& $D$ expenditures remained relatively steady at about $\$ 6.4$ billion per year, California firms experienced some fluctuation in the annual dollar value of contracts received. Nonetheless, California managed since 1961 to obtain an average of about 32.8 percent of the total $R$ \& $D$ contracts awarded by DOD. These awards would be equal in collar value to about 3.7 percent of the personal income of California. Table 17, below, Indicated the $R \& D$ contracts awarded California since $196 I$. In 1963, according to a study sponsored by the Stanford Research Institute, there were five areas in the Unt.ted States that could be consiaered major defense $R$ \& $D$ complexes. These complexes shared a total of 58.1 percent of the prime $R \& D$ contract awards during that year. of the five complexes, California's two major urban areas led the other areas which were located on the eastern seaboard. The "Southern California Complex" received 26.8 percent of the total awards, the "San Francisco-Bay Area" received 12.4 percent, the "New York City-Northern New Jersey" complex received 8.4 percent, and the "Boston--centered" and "Washington, D.C.--centered" complexes each recelved less than 6.0 percent. First and second tier subcontracts 
TABLE 17

VALUE OF $R$ \& $D$ CONTRACTS TO CALIFORNIA

AND THE NATION, 1961-1967

(In millions of dollars)

\begin{tabular}{l|c|c|c|c|c}
\hline \hline Year & $\begin{array}{c}\text { National } \\
\text { Total }\end{array}$ & $\begin{array}{l}\text { Cal1- } \\
\text { forn1a }\end{array}$ & $\begin{array}{l}\text { \% to } \\
\text { Cal1- } \\
\text { fornia }\end{array}$ & $\begin{array}{l}\text { Personal } \\
\text { Income } \\
\text { (state) }\end{array}$ & $\begin{array}{l}\text { Awaras a } \\
\text { as of } \\
\text { Personal } \\
\text { Income }\end{array}$ \\
\hline 1961 & $\$ 6,131$ & $\$ 2,492$ & 40.6 & $\$ 45,608$ & 5.5 \\
1962 & 6,319 & 2,438 & 38.5 & 48,980 & 5.0 \\
1963 & 6,376 & 2,567 & 40.2 & 52,431 & 4.9 \\
1964 & 7,021 & 2,258 & 32.1 & 56,264 & 4.0 \\
1965 & 6,236 & 1,502 & 24.0 & 59,476 & 2.5 \\
1966 & 6,259 & 1,683 & 26.8 & 65,156 & 2.6 \\
1967 & 6,700 & 1,989 & 29.7 & 69,932 & 2.8 \\
\hline
\end{tabular}

Sources: U.S., Congress, Joint Economic Committee, Economic Effect of Vietnam Spending, Hearings, before the Jolnt Economic Committee, Soth Cong., Ist sess., 1967, II, pp. 480, 1004, 1007, 1010, and 1016; and James L. Clayton, "The Impact of the Cold War on the Economies of Calif'ornia and Utah, 1946-1965," Pac1fic. Historical Review, XXXVI (November, 1967), Table II, p. 450. California, Department of Finance, California Statistical Abstract, 1969 (Sacramento, 1969), Table D-5, p. 52 .

studied (in this instance on NASA prime contracts) indicated the same general geographic pattern as was found at the prime contract level. 24 For example, a survey of twelve aerospace companies recelving prime contracts from NASA gave 34.3 percent of their material procurement subcontracts to

24 Albert Shapero, Richard P. Howell, and James $R$. Tombaugh, An Exploratory Study of the Structure and Dynanics of the $R$ \& D Industry (Menlo Park, California: Stanford Research Institute, 1954), p. 25. 
the two California complexes. 25 Further exploring this subject, Albert Shapero and others found that two unnamed San Francisco firms did 58 and 71 percent of their procurement in the Pacific Coast region. 69.5 percent of their procurement was subcontracted within California. One of the two firms procured materials totaling 41 percent of its dollar sales in the San Francisco Bay Area, 15 percent in the Southern California complex, 8 percent in Boston, 16 percent in the New York-New Jersey area, and less than .05 percent in the Washington, D.C. area. Shapero's evidence led him to believe that if $R$ \& $D$ companies were in the $\mathrm{R} \& \mathrm{D}$ complex area, a large percentage of procurement would be from that area. ${ }^{26}$ Another study sponsored by the Stanford Research Institute produced statistics which seemed to confirm Shapero's conclusion. According to this study, Bay Area firms conducted 41.3 percent of their material procurement within the Bay Area. 27 While information as to the exact dollar value of $R \& D$ contracts given the Bay Area

25Ibid., pp. $7^{8}$ and 82 .

26 Albert Shapero, Richara $P$. Howell, and James $R$. Tombaugh, The Structure and Dynamics of the Defense $R$ \& $D$ Industry: The Los Angeles and Boston Complexes (Menlo Park, Calffornia: Stanford Research Institute, 1965), pp. 69-71 and $75-76$.

27Richard P. Howell, William N. Breswick, and Ernest D. Wenrlck, Economic Impact of Defense R \& D Expendftures: In Terms of Value Added and Employment p. 11 . 
is still undisclosed, one can estimate that the region received roughly $\$ 459$ million in 1963 (12.4\% of $58.1 \%$ of the national total $R \& D$ contracts).

The real impact of this $\$ 459$ million, however, was not easily computed. Not all of 1 t was paid in wages and salaries, nor was it all put in procurement of materials elther within or outside the Bay Area. Shapero concluded that of three companies, which were analyzea over a six year period (1957-1952), 45.2 percent of their sales dollar went to material procurement. Of the twelve aerospace companies mentioned above, the average percentage of sales dollar spent for materials was 45.8 in 1955 and 44.5 in 1961. Approximately 37.6 percent of the average 1961 sales dollar of these companies went into wages and salaries. Shapero suggested that when these figures were applied to first and second tier subcontract levels, a minimum of 61.7 percent of the defense $R$ \& $D$ prime contract dollar could be estimated as belng spent for wages and salaries. ${ }^{28}$ Using these conclusions, one could estimate the dollar impact of the $R$ \& $D$ prime contracts entering the Bay Area. If 37.6 percent of the $\$ 459$ milition in prime awards in 1963 went

28 Shapero, Howell, and Tombaugh, Exploratory Study, pp. 30 and 76. The total labor portion of the $R \&$ D prime contract dollar was derived from the following equation: Labor portion of dollar $(.617)=(.376)-(.376)(.445)-$ $(.376)(.445)(.445)$. Note that the 1951 figure for expenditures for material has been used. 
Into payment of wages and salaries in the Bay Area, then approximately $\$ 172$ million became a part of the personal Income of Bay Area residents. Furthermore, if it was assumed that about 40 percent or $\$ 81$ miliion of the 44.5 percent of prime contracts to the Bay Area which were subcontracted went to firms within the Bay Area, one must add about $\$ 30$ milizon more in wages and salaries paid at the first tier subcontract level within the Bay Area and approximately $\$ 14$ milion more in wages and salaries paid at the second tier. Thus, roughly $\$ 216$ million of the $\$ 459$ militon originally awarded to Bay Area firms became a part of the region's personal income in 1963. About 1.6 percent of the total personal income of the region (\$12.7 billion) came from defense $R$ \& $D$ prime contracts. This equals approxinately $\$ 58$ per capita--1.7 percent of the per capita personal income of $\$ 3,449$ and 2.2 percent of the $\$ 2,656$ per capita net buying power. This, of course, does not take into consideration the multiplier effect of the $\$ 216$ million. This aspect of impact, which indicated that $R$ \& $D$ income made up about 4.9 percent of Bay Area personal income and over one-half of total Bay Area defense Income, will be consldered below (infra, pp. 150-56). The $R$ \& $D$ industry has had many effects on the communities in which it was concentrated, some economic in nature and others social and political. Naturally, the industry created a demand for housing, services, and 
community facilities. The effect of in-migration of population and, subsequently, its effect on local crnsumer spending was felt. Of course, these were effects on the community that would result from any industry, but it was important to consider this impact. The industry certainly made a significant impact on wages and salaries, taxes, and use of utilities--a sizable impact according to a study of the $R \& D$ industry in Santa Clara County. However, the percent of the industry's income which found its way to retail stores and everyday service establishments may not have been as large. 29 There was some controversy as to the importance of local markets in supplying the $R \& D$ industry with goods and services, yet one of the Stanford Research Institute studies suggested thls was significant. Purchases of goods and services were extensive, including blueprint services, car rentals, catering services, office furniture, and hotel and restaurant services. 30 It has already been noted that there was a tendency for $R$ \& $D$ firms within a community to supply each other with goods and services. A further effect of the industry was in its influence upon the community's educational system. A direct impact was made

29 Info Commentary, p. 15.

30 Shapero, Howell, and Tombaugh, Exploratory Study, p. 101. Info Commentary, p. 15, presents a contrary view, stating that local markets are inconsequential in supplying the indistry with goods and services. 
on the size of graduate school facilities, as the Industry provlded both part-time faculty and students as well as laboratory facilities and computer services. There was also a tendency to improve local primary and secondary schools and curricula through the participation of the predominantly white-collar $R$ \& $D$ employees in local school affairs. 31 The effects of the industry, then, were widespread. Obviously, they did not seem to be detrimental to the community, but few of the effects were a result of the type of work done in the defense $R$ \& $D$ industry. In fact, it is most important to note that there may have been little direct benefit from defense $R \& D$ on the civilian economy or quality of life. On the other hand, if the dollars for basic science research provided by the military had not been available, they might not have come from any other source. Yet this contention is hypothetical.

Another step in analyzing the impact of defense spending in an area was to calculate the value of pritne contracts let to the area by the Department of Defense and other agencies. Data, however, is still not as complete as one would deslre. Generally, only procurement contracts of $\$ 10,000$ or more were included in prime contract data. The contract values were recorded in the year the award was

31Shaperc, Howell, and Tombaugh, Exploratory Study, pp. 103-104. 
made, yet spending was frequently spread over several years. 32 Murray Weidenbaum discussed this in recent testimony before Congress, showing the relationship of active Alr Force expenditures to the "new obligational authority" received annually for this department. Table 18 illustrates the percentage of the Air Force "new obligational authority" expended over a five year perlod for the years 1951, 1952 , and 1953. The difficulties in estinating impact suggested by this time lag in actual expenditures are obvious. There were also problems in attaching specific awards to the plant In which the work was actually to be performed. Since most companies receiving awards were large and sometimes had piants in several locations, this was not a minor problem. Finally, sub-contracting was not considered at all when dealing with prime contract data. This was a major problem as one could not judge effectively the amount of the award remaining within the reciplent company. 33

California had been the leading recipient of prime

32Mosbaek, "Reductions in Defense Expenditures," p. 64, citing observations by economist Robert A. Solo.

33George Jensen, "Information on the Impact of Defense Expenditures: A Comment," Quarterly Review of Economics and Business, VI (Fall, 1966), 79-80. Clayton, "Impact of the Cold War," $p_{i} 453$, suggests, however, that use of prime contract data". - is a generally accurate and widely acceptable approach--particularly over a series of years." In analyzing 1mpact at the state or larger regional level this may be somewhat true, but Clayton's judgment can be accepted for an analysis of a smaller geographic area only with caution. 
TABLE 18

RELATIONSHIP OF ACTUAL EXPENDITURES TO NEW OBLIGATIONAL AUTHORITY, USAF, FISCAL YEARS 1951-1953

\begin{tabular}{l|c|c|c|c|c}
\hline \multirow{2}{*}{ NoA } & \multicolumn{5}{|c|}{ Percent Expended } \\
\cline { 2 - 6 } & Ist Year & 2nd Year & 3rd Year & 4th Year & 5th Year \\
1951 & 25 & 40 & 28 & 6 & 1 \\
1952 & 23 & 36 & 28 & 9 & 2 \\
1953 & 29 & 35 & 30 & 8 & 3 \\
\hline \multirow{2}{*}{ Average } & 26 & 37 & 25 & 8 & 2 \\
\hline
\end{tabular}

Source: U.S., Congress, Joint Economic Committee, Econonic Fffect of Vietnam Spending, Hearings, before the Joint Economic Committee, Goth Cong., lst sess., 1967, II, p. 613.

awards during most of the years since the Korean War. Between $195 \mathrm{i}$ and 1965 the state received an annual average of $\$ 4,478,357,000$ in prime contracts from the DOD, approximately 20.6 percent of the total annual awards let in the nation. When the contracts awards let by NASA were considered during the years since 1960 when data became available, the average jumped to $\$ 5,523,789,000$ from 1961 to 1965. During this perlod about 45.9 percent of NASA's total prime contracts went to California each year. Table 19 gives the annual totals for California during these years. An interesting study by the United States Commerce Department, dealing with total federal procurement in California, indicated that $\$ 10,374$ million in prime contracts were awarded the state in 1963. By breaking this total into 
TABLE 19

CALIFORNIA SHARE OF U.S. DEFENSE-SPACE CONTRACTS, 1951-1967 (Thousands of dollars)

\begin{tabular}{|c|c|c|c|c|c|c|}
\hline \multirow{2}{*}{$\begin{array}{c}\text { Fiscal } \\
\text { Year } \\
\end{array}$} & \multicolumn{3}{|c|}{ Dollar Awards } & \multicolumn{3}{|c|}{ Percent of U.S.* } \\
\hline & DOD & NASA & Tota 1 & DOD & NA.SA & Total \\
\hline $\begin{array}{l}1951 \\
1952 \\
1953 \\
1954 \\
1955 \\
1956 \\
1957 \\
1958 \\
1959 \\
1950 \\
1961 \\
1962 \\
1963 \\
1964 \\
1965 \\
1966 \\
1967\end{array}$ & $\begin{array}{r}\$ 3,897,915 \\
4,907,845 \\
4,161,835 \\
2,761,574 \\
2,813,676 \\
3,311,203 \\
3,381,927 \\
4,457,666 \\
5,282,659 \\
4,839,252 \\
5,276,760 \\
5,993,244 \\
5,835,670 \\
5,100,650 \\
5,153,639 \\
5,813,078 \\
6,688,812\end{array}$ & 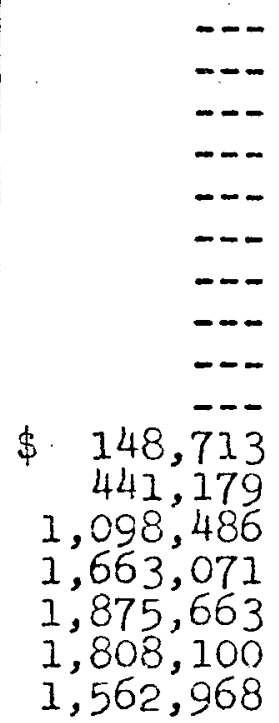 & $\begin{array}{r}\$ 3,897,915 \\
4,907,845 \\
4,161,835 \\
2,761,574 \\
2,813,576 \\
3,311,203 \\
3,381,927 \\
4,457,666 \\
5,282,659 \\
4,839,252 \\
5,425,473 \\
6,434,423 \\
6,934,156 \\
6,763,721 \\
7,029,302 \\
7,621,178 \\
8,251,819\end{array}$ & $\begin{array}{l}13 \cdot 2 \\
12.8 \\
15.4 \\
26.0 \\
20.1 \\
20.1 \\
18.8 \\
21.4 \\
24.0 \\
23.7 \\
23.9 \\
23.9 \\
23.1 \\
21.0 \\
22.1 \\
18.3 \\
17.9\end{array}$ & $\begin{array}{l}--- \\
--- \\
--- \\
--- \\
--- \\
--- \\
--. \\
-.- \\
--- \\
-\cdots \\
39.1 \\
47.0 \\
50.4 \\
47.6 \\
45.7 \\
43.8 \\
39.6\end{array}$ & $\begin{array}{l}13.2 \\
12.8 \\
15.4 \\
26.0 \\
20.1 \\
20.1 \\
18.8 \\
21.4 \\
24.0 \\
23.7 \\
24.1 \\
24.8 \\
25.3 \\
24.2 \\
25.7 \\
21.3 \\
20.0\end{array}$ \\
\hline
\end{tabular}

*Percent of awards allocated by states.

Sources: California, Governor, Economic Report of the Governor, 1968 (Sacramento, 1958), Table 10, p. 30. See also California, Department of Finance, California Statistical. Abstract, 1968 (sacramento, I968), Tables I-I and I-4, pp. 135-35; California, Department of Finance, State of fice of Planning, California State Development Plan Program: Progress Report and Summary Interpretations of Phase I Studies (Sacramento, February, 1965), p. 22; and U.S., Congress, Joint Economic Comittee, Economic Effect of Vietnam Spendins, HearIngs, before the Joint Economic Committee, 90th Cong., lst sess., 1967, II, pp. 894 and $907-908$. 
industrial sectors, the study estimated that $\$ 2,997$ m1IIion went into ordnance, $\$ 621$ militon into electronics, $\$ 2,094$ million into alrcraft and parts, $\$ 1,461$ million into trade industries, $\$ 734$ milizon into business and $R$ \& $D$ services, and $\$ 704$ milition into personal services. However, when totaled, the sum did not match the study's earlier figure for national procurement in the state. 34 Explanations were unfortunately vague in the study, yet the study was Illustrative of the type of calculations made with prime contract data. One did not need to rely only on state or regional totals.

Since 1960, a research program has been sponsored variously by the Regional Science Research Institute at the University of Pennsylvania and World Friends Researeh Center to develop some understanding of the Industrial and local to regional impact of prime contract awards. 35 The

34 U.S., Department of Commerce, Economic Development Administration, Report of the Independent Study Board on the Regional Effects of Government Procurement and Related Policies (Washington, D.C.: Government Printing office, December, 1967), pp. 15 and 23 (Hereinafter referred to as Regional Efrects of Government Procurement).

35Walter Isard and James Ganschow, Awards of Prime Military Contracts by County, State, and Metropolitan Area of the United States, Fiscal Year 1960 (Philadelphia: Regional Science Research Institute, University of Pennsylvania, 1960); Walter Isard and Gerald J. Karaska, Unclassifled Defense Contracts: Awards by County, State, and Metropolitan Area of the United States, Fiscal Year I962 (Philadelphia: World Frlends Research Center, Inc., 1562); and Walter Isard and Gerald J. Karaska, Unclassified De fense and Space Contracts: Awaras by County, state, and Metropolitan 
data collected by those involved was most helpful in determining impact, but it was not consistent with other data nor compiete in all respects. Prime contract awards of $\$ 10,000$ or more were, as in other studies, used in part of the calculations for this research program, while data for a large part of the study utilized unclassified contracts only which did not include all prime contracts. Furthermore, only net contract awards were considered; 1.e., minus contract cancellations. DOD and NASA contracts were separated, the latter being dealt with only for the year 1964. Finally, in addition to ranking states, metropolitan areas, and counties, awards were broken down by four digit standard industrial code (SIC) ciassifications. For example, under the SIC system, the code number 3721 would indicate "guided missiles" industry and SIC 7399 would signify "commercial research" industry. 36

Using the data collected for the fiscal years 1950, 1962, and 1964, one could begin to judge the impact of defense spending upon the Bay Area. For example, in FY 1960, approximately $\$ 1,114,370,000$ in prime contract awards from

Area of the United States, Fiscal Year 1964 (Philadelphia: Worid Friends Research Center, Inc., 1965) (Hereinafter each report will be referred to as Isard, [with appropriate year] ).

${ }^{36}$ Fuller explanation of research considerations are found in Isard, 1960, pp. 1-2; and in Isard, 1962 and 1964, pp. 1-5, passim. 
DoD entered the Bay Area--22.8 percent of the total awards to the state. The two SMSA's making up the b?y region-San Francisco-Oakland and San Jose--were ranked fifteenth and fourth respectively in value of contracts recelved among the nation's SMSA's. Together they acquirea 5.3 percent of total DOD awards for FY 1960. While the counties in the area were almost all in the top 150 counties in the nation receiving awards, none could top Santa Clara County (the San Jose SMSA) which received almost $\$ 800$ million in awards--3.69 percent of the national counties. The Bay Area thus recelved about $\$ 1,330$ per capita in contracts in FY 1960, with Santa Clara County accounting for \$I,208 per capita. Thus, the per capita awards amounted to abolit 44 percent of a per capita persoral 1ncome of about $\$ 2,970$ in the Bay Area, and approximately 44 percent of a per capita personal income of about $\$ 2,690$ in Santa Clara County. 37 As seen in Table 20, data for 1962 and 1964 differed radically from that for 1960, for the latter years Included only figures for unclassified contracts. Nonetheless, the figures were sizeable and gave some indication of impact. Finally, Table A, Appendix IV, gives Bay Area awards by two digit SIC for the same years. The implications

37 Calculated from supra, Table 12, v. 58; infra, Table 20, p. 117; and Abstract, 1968, p. 55. The percentages of net buying power were somewhat higher: 53 percent of the Bay Area's $\$ 2,514$ per capita net buying power and 53 percent of Santa Clara County's $\$ 2,300$ per caplta net buying power. 
TABIL 20

DEPARTMENT OF DEFENSE PRIME AND UNCLASSIFIED CONTRACT AWARDS TO CALIFORNIA AND THE BAY AREA, FISCAL YEAFS 1950, 1962, AND 1964

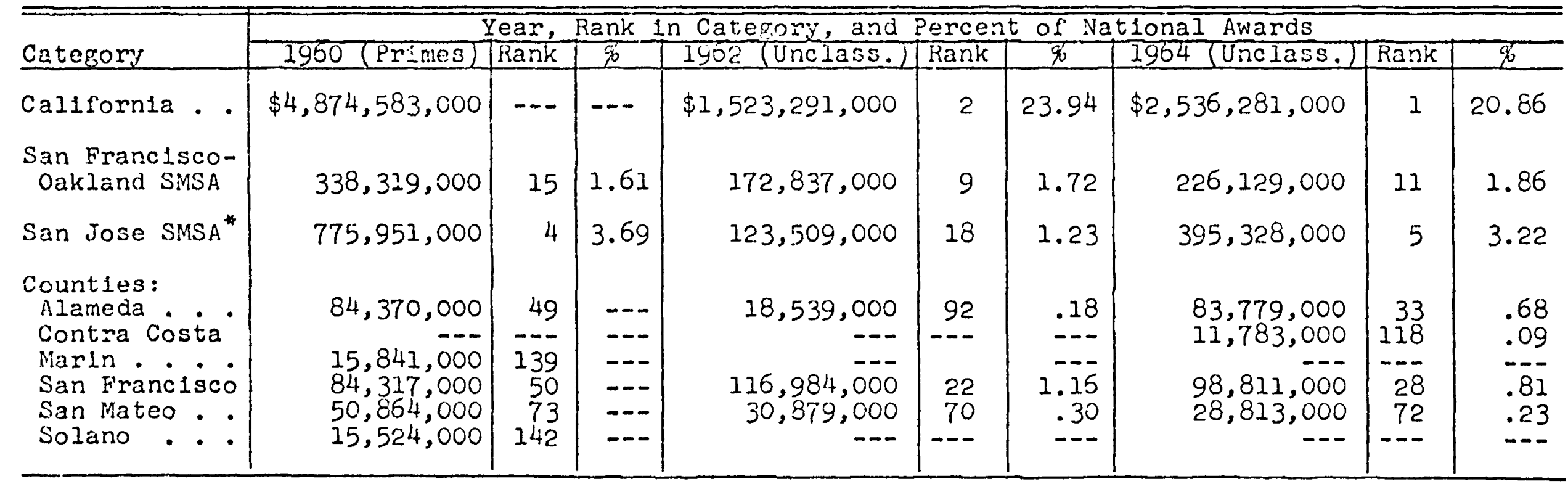

*Equivalent to Santa Clara County.

Sources: Walter Isard and James Ganschow, Awards of Prime M111tary Contracts by County, State, and Metropolitan Area of the United States, iscal Ycar 1960 (Philadelphia: Reglonal Science Research Institute, University of Pernsylvania, 1900). Tables 1-3, pp. 5, 9, and 14-15; Walter Isard and Gerald J. Karaska, Unclasiflied Defense Contracts: Awards by ( ounty, State, and Metropolitan Area of the United states, Fiscal Year lg62 (Philadelphia: World F'rlends Research Center, Inc., 1962), Tables 1, and 4-5, pp. 4, 10, and 14-15; and Walter Isard and Gerald J. Karaska, Unclassifled Defense and Space Contracts: Awards by County, State, and Vietropolitan Area of the United States, Fiscal Year 1964 (Ph11adelphia: World friends kesearch center, Inc., 1965). 'lables 1, 3, and 5-6, pp. 4, 7, 12, and 
of these statistics will be dealt with below.

Prime contract data was the basic date available in estimating defense impact, yet it was by no means comprehensive. One of the most difficult areas in judging impact was in the subcontract field. The Subcommittee on Economic Development of the California Assembly Interim Committee on Ways and Means pointed out, in 1965, that subcontracts from California golng to out-of-state firms were largely offset by the volume of subcontracts won by firms in the state from out-of-state prime contractors. California's governor, Ronald Reagan, later suggested that subcontracting simply did not affect the overall volume of prime awards awarded in the state. 38 If such was the case, then subccntract studies directed at the state level would be of limited value. 39 Yet the subcontracting within a state may well have been significant for the final impact of prime contracts on certain areas in the state.

Conclusions about the final impact of prime awards after subcontracting were at best educated guesses. E.D. Carter, the Corporate Director of Martin Company--a leading aerospace firm--has generalized that about 50 percent of prime contracts were subcontracted. For example, in FY 1960,

38 Impact of Federal Spending in California, p. 10; and Report of the Governor, 1968, p. 20 .

39No comprehensive studies dealing with subcontracting were avaliable to the author. Because of the difficulty in obtaining such data from individual companies, few studies seem to exist. 
Martin Company concluded 182,000 purchase transactions, dealing with around 9,700 suppliers; this involved 43 percent of the firm's total sales for that period. 40 In a study of twelve NASA prime contractors presented before hearings of the Senate Select Committee on Small Business in 1964, the data revealed would seem to substantlate Carter's Information. Between July 1 and December 31, 1963, 41.5 percent of the prime contracts received by the companies studied were subcontracted. During a longer period, January 1, 1962 to December 31, 1963, the percentage subcontracted totaled 43.6 of the prime contracts. 41 In a study of the defense market between 1955 and 1954, William L. Baldwin observed that DOD did not make available comprehensive information concerning subcontracting firms of prime contractors, so accuracy was difficult in judging the subcontract impact. Baldwin's research did reveal, however, that approximately 49.8 percent of the military prime contract payments received by all firms were pald out as subcontracts. Interestingly, small business firms received somewhat less than half of the subcontracts let--an average

HO Niartin Company, The Missile Industry in Defense and the Expioration of Space (Baltimore: The Martin Company, 1961), pp. 87-88.

${ }^{4} I_{U} . S_{.}$, Congress, Senate, Select Committee on Small Business, Smali Business Conversion Problems--1964, Hearings, before the Select Committee on Smali Business, senate, both Cong., 2d sess., 1964, p. 167 (Herelnafter referred to as Smali Business Conversion... Hearings). 
of 18.7 percent of the prime contract payments (Table 21). While small firms probably tended to concentrate much of their efforts in supplying larger companies, Baldwin's data indicated that larger firms procured more of the subcontracts than did the small companies.

If close to half of the prime contracts were indeed subcontracted, this would certainly suggest that use of prime contract data to determine impact remained rather risky. However, if the bulk of the subcontracts let by prime contractors in an area stayed within that region and if these were supplemented with a small number of subcontracts let from outside the area, perhaps the subcontract Impact could be ignored to some extent. James L. Ciayton, In his study of the California defense economy, suggested that most subcontracts tended to stay within the area of the prime grant. He added that prime $R$ \& D contracts ". . undoubtedly stayed in California." His conclusion was that most prime contract investment remained in California and that, furthermore, subcontracts entering the state from prime contractors outside California made it conceivable that the state received more in defense spending than prime awards would indicate. 42 In a report on the subcontracting patterns of major defense contractors submitted to the Secretary of Defense and presented before corgressional

$$
42 \text { Clayton, "Impact of the Cold War," pp. 453-54. }
$$


TABLE 21

SUBCONTRACTING AS A PERCENTAGE OF PRIME CONTRACT PAYMENTS, 1957-1963, BY PRIME CONTRACTORS

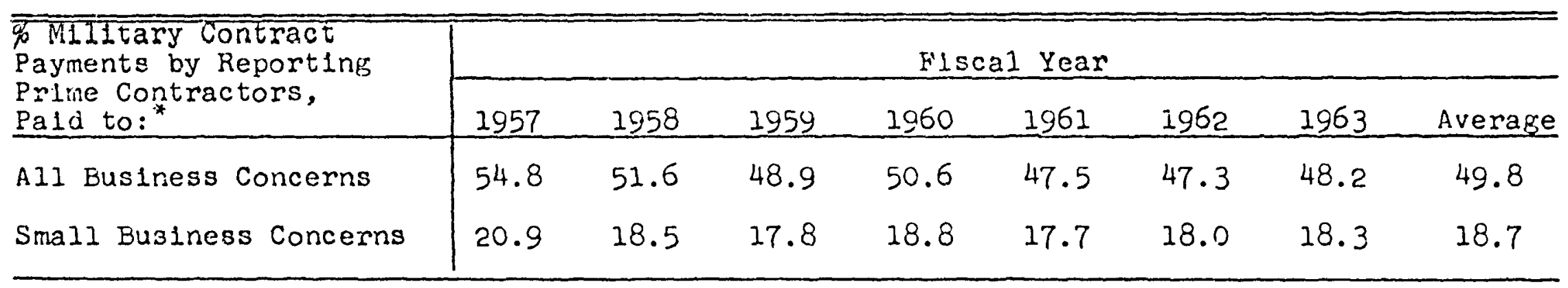

*Voluntary prior to 1960.

Source: Willlam L. Baldwin, The Structure of the Defense Market, $1955-1964$ (Durham, North Carolina: Duke University Press, 1967), p. 28. 
hearings in $1967, C-E-I-R$, Inc. presented data indicating that almost 53 percent of the subcontracts let by 1 ts prime contractors was retained. However, the report noted that the general trend of subcontracts was to flow toward the northeast and north central part of the country. California obtained fewer outside subcontracts than those from prime contractors within the state. ${ }^{4} 3$ Probably Clayton's conclusions were somewhat speculative, for the C-E-I-R report Indicated a probable overall loss of prime contracts to the state as a result of the subcontract flow. Even Clayton admitted that not all of the original NASA awards to the state were retained or came back into Californla via subcontracts, although over 90 percent remained. 44 Despite the studies done on the subcontract flow, however, the data avaliable was very vague and conclusions remained inadequate. If further conclusions about defense impact were to be made, one had to assume that the subcontract flow made little overall change to origlnal prime contract awards.

The use of prime contract data and the consideration of the subcontract flow were basic for most analyses of

43U.S., Congress, Joint Economic Committee, Economic Effect of Vietnam Spending, Hearings, before the Joint Economic Committee, 90th cong., Ist sess., 1957, II, p. 791 (Hereinafter referred to as Vietnam Spending).

${ }^{44}$ Clayton, "Impact of the Cold War," p. 454. 
defense impact upon a region, yet other approaches could be used. A somewhat useful method was to study the Impact of defense-oriented procurement on a specific industry. The electronics industry was a good example of an industry signfficantly influenced by defense and space spending levels. The Electronics Industries Association demonstrated the importance of defense-oriented procurement to the industry in data presented in Governor Ronald Reagan's 1968 report on the California economy. As seen in Table 22, the electronic content of the Iisted DOD procurement categories averaged about 34.5 percent and that of NASA sectors was approximately 47.0 percent in 1967. Overall, the 1967 DOD procurement in electronic content totaled 15.1 percent. An indication of the monetary impact of tris procurement can be easily given. For example, in 1967, DOD procurement for alreraft totaled $\$ 8.0$ billion. Hence, the 25.8 percent of this figure expended for electronic components amounted to about $\$ 2.1$ billion. Total DOD expenditure, minus that for military assistance programs, was $\$ 66.9$ billion for 1967 ; and, if 15.1 percent of the amount accrued to the electronics Industry, directly or indirectly, the industry would have gained about $\$ 10.1$ billion in sales. 45 one study noted that the government products sector of the electronics industry

\footnotetext{
45Calculated from Table 21 and DOD expenditures found in Vietnam Spending, II, p. 480.
} 
ELECTRONIC CONTENT: AVERAGE PERCENT BY PROCUREMENT CATEGORY, 1967

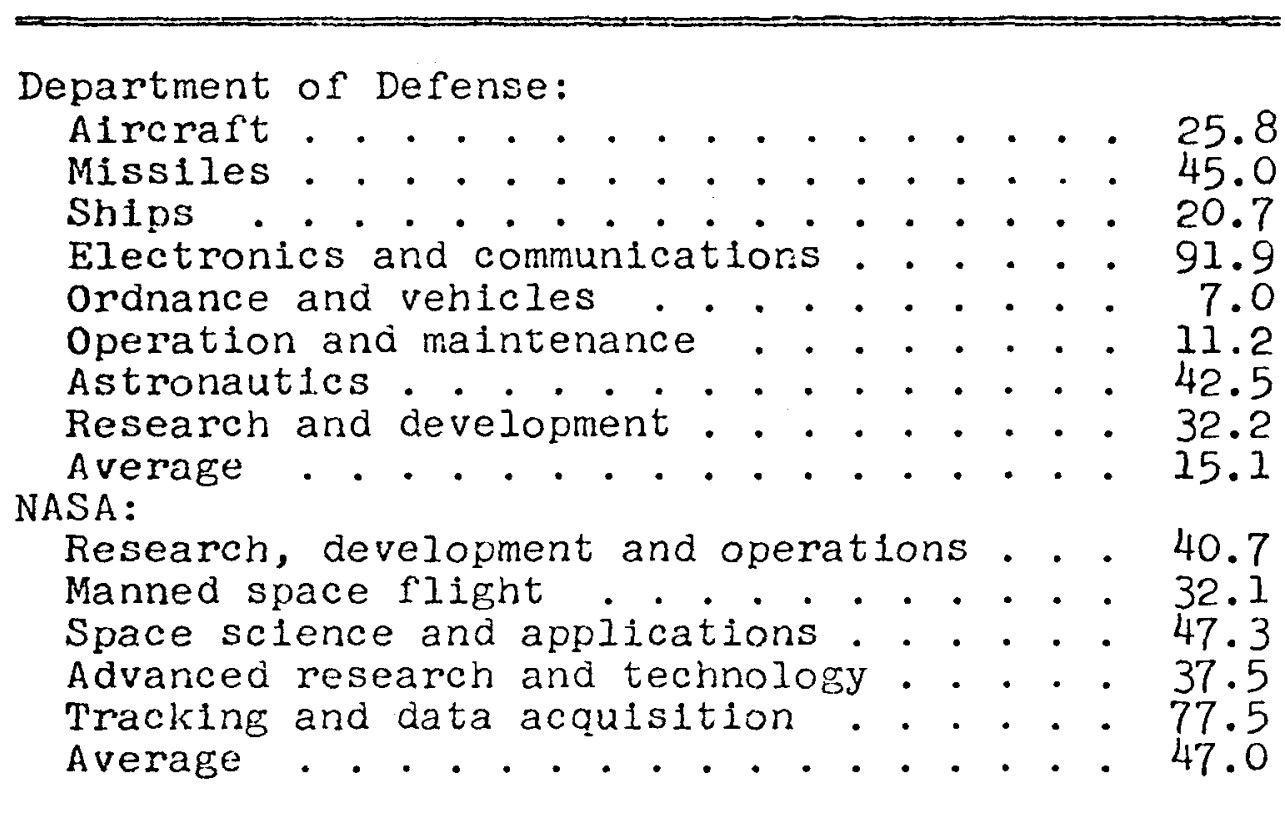

Source: California, Governor, Economic Report of the Governor, 1958 (Sacramento, 1968), p. 31.

factory sales amounted to $\$ 8.8$ billion in $1965--51.2$ percent of the industry's total sales of $\$ 17.2$ billion. The direct government sales of the Industry equaled one-half of total sales. The addition of indirect sales to the government through sales of industrial products to other industries would have somewhat increased the percent of total sales to the government. 46

Studies of the electronics industry in the Bay Area

46Carl Lindner, "Diversification Progress," p. 97. 
Indicated that the industry was primarily defense-oriented. A 1958 survey reported by Robert K. Arnold presented data for 46 Bay Area electronics firms. $\$ 67.2$ million in sales were the result of military prime and subcontracts, and $\$ 49.1$ militon were industrial sales primarily for military use. These sales amounted to 60.7 percent of the Bay Area electronics industry's total sales of $\$ 191.8$ million. 47 If 60.7 percent of these sales supported the same percentage of the 22,968 employees in the electrical machinery industries of the Bay Area, approximately 13,941 employees earning about $\$ 103.2$ million would have been supported by military-space spending in 1958--one-half a percent of the Bay Area personal income. Lindner's study of electronics industry diversification was likewise relevant to the impact of defense spending in the bay region. Lindner revealed that In 1964 almost $\$ 30$ million was contributed by defense spending to Palo Alto's economy in Iocal purchases and taxes. More generally, his study of 56 electronics firms in the Bay Area revealed that 75 percent of total sales in 1961 and 67 percent in 1965 went to military and space endeavors. He suggested that the 15 percent decline in military sales (see Table 23) between these years was particularly significant in view of the total military market increase attributable to the Vietnam conflict. However, it should be noted

47Arnold, California Economy, pp. 449-50. 
TABLE 23

PERCENT SALES OF BAY AREA ELECTRONICS FIRMS

TO MAJOR MARKETS, 1961 AND 1965

\begin{tabular}{|c|c|c|c|c|c|}
\hline Year & Military & Space & other Govt. & Industry & Consumer \\
\hline $\begin{array}{l}\text { Group I: } \\
1961 \\
1965\end{array}$ & $\begin{array}{l}38.0 \\
34.0\end{array}$ & $\begin{array}{r}4.0 \\
13.0\end{array}$ & $\begin{array}{r}14.0 \\
7.0\end{array}$ & $\begin{array}{l}37.0 \\
41.0\end{array}$ & $\begin{array}{l}7.0 \\
5.0\end{array}$ \\
\hline $\begin{array}{l}\text { Group II: } \\
1961 \\
1965\end{array}$ & $\begin{array}{l}68.0 \\
52.0\end{array}$ & $\begin{array}{r}9.0 \\
18.0\end{array}$ & $\begin{array}{l}3.5 \\
4.0\end{array}$ & $\begin{array}{l}19.0 \\
25.0\end{array}$ & 1.5 \\
\hline $\begin{array}{l}\text { Group III: } \\
1961 \\
1965\end{array}$ & $\begin{array}{l}70.0 \\
56.0\end{array}$ & $\begin{array}{r}5.0 \\
10.0\end{array}$ & $\begin{array}{l}2.0 \\
4.0\end{array}$ & $\begin{array}{l}20.0 \\
25.0\end{array}$ & $\begin{array}{l}3.0 \\
5.0\end{array}$ \\
\hline $\begin{array}{c}\text { A11 Groups: } \\
1961 \\
1965\end{array}$ & $\begin{array}{l}70.0 \\
55.0\end{array}$ & $\begin{array}{r}5.0 \\
12.0\end{array}$ & $\begin{array}{l}3.0 \\
4.0\end{array}$ & $\begin{array}{l}20.0 \\
25.0\end{array}$ & $\begin{array}{l}2.0 \\
4.0\end{array}$ \\
\hline
\end{tabular}

Firm Sizes:

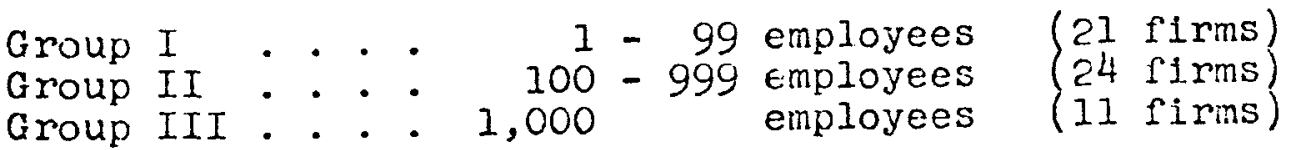

Source: Carl Lindner, "Diversification Progress and the San Francisco Bay Area Electronics Industry" (unpublished MA thesis, San Jose State College, $1967)$, p. 36.

that the increase was in conventional weapons with a small portion of electronic parts. Hence, the decrease in the military part of the Bay Area electronics industry sales was less significant than Lindner indicated. 48 It should be

48 Iindner, "D1versification Progress," pp. 8-9, 36, and 69. "Northeast of Saigon," Federal Reserve Bank of 
noted, too, that the space market showed marked growth for the region's electronic industry (Table 23). Nonetheless, the percentage of sales Lindner found attributable to military-space spending was sizable. If these percentages were possibly applicable to the number of employees in the Bay Area's electrical machinery industries supported by military-space spending, the employees in 1961 would have numbered about 25,142 earning some $\$ 142.5$ million. In 1965 they would have numbered approximately 27,001 and earned about $\$ 201.0$ mililon. This equaled about one percent of the Bay Area's personal income in both years. One further observation of Lindner's study revealed that the larger electronics firms concentrated more of their sales to the government market than did flrms employing from 1-99 persons. Undoubtedly, the smaller firms had more sales to the government than were readily seen, but many were subcontracts from larger prime contractors. Based on these studies by Arnold and Lindner, one may conclude there was a sizable influence by defense spending upon the Bay Area electronics industry. Another approach used in evaluating impact upon industrial groups was to determine the percentage of company sales to the government. A market survey by the author provided usable data pertaining to sales distribution

San Francisco, Monthly Review, June, 1966, pp. 118-19, discusses the shif't to conventional weapons production. 
between 1955 and 1965 for forty-six Bay Area companies employing approximately 51,831 persons--17.93 nercent of total 1965 Bay Area manufacturing employment. 49 While the results may not have been applicable to total bay region manufacturing sales distribution, they were indicative of general trends, especially in certain industries surveyed. Companies replying included one in the ordnance and accessories fleld (SIC 19), one in rubber and plastics (SIC 30), one in fabricated metal products (SIC 34), three in nonelectrical machinery (SIC 35), 28 in electrical machinery (SIC 36), one in transportation eciulpment (SIC 37), seven in scientific and mechanical instruments and $R$ \& $D$ (SIC 3811 and 3821 ), and two in industries not elsewhere classified (SIC 3999). The companies employed the equivalent of 36.6 percent of the 136,900 workers who were paid wages and salarles in 1965 by flrms in these SIC classifications.

These workers further were paid an estimated $\$ 388$ million in wages and salaries. 50

General results of the survey (Table 24) indicated

49 These 46 firms amounted to 18.5 percent of the 248 companies contacted. For the market survey questionnaire see, Infra, Appendix III, pp. 204-07. While only 46 companies returned usaole historicai sales data, 60 firms returned usable 1969 market data. Thus, a 24.19 percent overall return rate was experienced. Eight questionnaires were returned undelivered, 19 were returned unusable, and 161 were not returned. Infra, Table $B$, Appendix III, p. 202, and Tables $24-26$, pp. I29 and 132-133, contain the major results of this survey.

${ }^{50}$ Calculated from data in Table 24 and Infra, Tables $B$ and D, Appendix II, pp. 196 and 198. 
129

THES 24

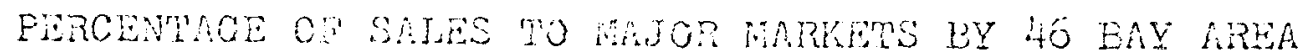

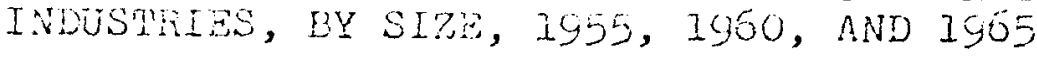

\begin{tabular}{|c|c|c|c|c|c|c|}
\hline Yoar & MLIItary & Snace & $\begin{array}{l}\text { Other } \\
\text { Govi. }\end{array}$ & $\begin{array}{l}\text { Indus- } \\
\text { try }\end{array}$ & Consumer & TotaI \\
\hline $\begin{array}{c}\text { Group I } \\
1555 \\
1960 \\
1965\end{array}$ & $\begin{array}{l}40.00 \\
52.50 \\
32.50\end{array}$ & $\begin{array}{r}7.50 \\
17.50\end{array}$ & $\begin{array}{r}10.00 \\
5.00 \\
5.00\end{array}$ & $\begin{array}{l}50.00 \\
35.00 \\
45.00\end{array}$ & $\begin{array}{l}-- \\
--\end{array}$ & $\begin{array}{l}100.00 \\
100.00 \\
100.00\end{array}$ \\
\hline $\begin{array}{c}\text { Group II } \\
3955 \\
1000 \\
1905\end{array}$ & $\begin{array}{l}50.75 \\
64.11 \\
57.11\end{array}$ & $\begin{array}{l}1.25 \\
1.11 \\
2.30\end{array}$ & $\begin{array}{l}9.53 \\
9.56 \\
7.45\end{array}$ & $\begin{array}{l}17.85 \\
17.44 \\
26.03\end{array}$ & $\begin{array}{r}12.51 \\
7.78 \\
7.11\end{array}$ & $\begin{array}{l}100.00 \\
100.00 \\
100.00\end{array}$ \\
\hline $\begin{array}{c}\text { GIOUD III } \\
1925 \\
1960 \\
1995\end{array}$ & $\begin{array}{r}5.00 \\
10.00 \\
12.50\end{array}$ & 25.00 & $\begin{array}{l}3.00 \\
3.00 \\
4.50\end{array}$ & $\begin{array}{l}92.00 \\
87.00 \\
31.75\end{array}$ & 26.25 & $\begin{array}{l}100.00 \\
100.00 \\
100.00\end{array}$ \\
\hline $\begin{array}{c}\text { arowe IV } \\
1955 \\
1960 \\
1965\end{array}$ & $\begin{array}{r}3.33 \\
19.85 \\
34.05\end{array}$ & $\begin{array}{l}3.33 \\
8.14 \\
9.25\end{array}$ & $\begin{array}{r}1.00 \\
17.57 \\
7.00\end{array}$ & $\begin{array}{l}89.00 \\
54.43 \\
47.75\end{array}$ & $\begin{array}{l}-- \\
--\end{array}$ & $\begin{array}{r}96.66^{*} \\
100.00 \\
100.00\end{array}$ \\
\hline $\begin{array}{c}02010 \mathrm{~V} \\
=355 \\
1900 \\
2965\end{array}$ & $\begin{array}{l}20.00 \\
10.00 \\
11.43\end{array}$ & $\begin{array}{l}20.00 \\
20.60 \\
16.43\end{array}$ & $\begin{array}{c}5.00 \\
-71\end{array}$ & $\begin{array}{l}60.00 \\
65.00 \\
68.57\end{array}$ & $\begin{array}{l}5.00 \\
5.00 \\
2.86\end{array}$ & $\begin{array}{l}100.00 \\
100.00 \\
100.00\end{array}$ \\
\hline $\begin{array}{c}\text { Grou VI } \\
1955 \\
1960 \\
1965\end{array}$ & $\begin{array}{l}40.00 \\
38.00 \\
32.85\end{array}$ & $\begin{array}{l}5.00 \\
6.00 \\
7.05\end{array}$ & $\begin{array}{l}15.00 \\
20.00 \\
13.57\end{array}$ & $\begin{array}{l}38.75 \\
34.00 \\
42.60\end{array}$ & $\begin{array}{l}1.25 \\
2.00 \\
2.85\end{array}$ & $\begin{array}{l}100.00 \\
100.00 \\
100.00\end{array}$ \\
\hline $\begin{array}{c}\text { Group VII } \\
1955 \\
1960 \\
1965\end{array}$ & $\begin{array}{r}5.00 \\
6.25 \\
19.00\end{array}$ & $\begin{array}{l}1.25 \\
3.06\end{array}$ & $\begin{array}{l}5.00 \\
5.00 \\
3.00\end{array}$ & $\begin{array}{l}90.00 \\
85.00 \\
7.00\end{array}$ & $\begin{array}{r}-5 \\
2.50 \\
2.00\end{array}$ & $\begin{array}{l}100.00 \\
100.00 \\
100.00\end{array}$ \\
\hline $\begin{array}{l}A 3 \text { (6) } \\
1955 \\
1960 \\
1665\end{array}$ & $\begin{array}{l}34.04 \\
35 \cdot 54 \\
31.34\end{array}$ & $\begin{array}{l}3.80 \\
5.23 \\
9.85\end{array}$ & $\begin{array}{r}8.52 \\
11.40 \\
7.13\end{array}$ & $\begin{array}{l}47.90 \\
44.50 \\
46.93\end{array}$ & $\begin{array}{l}5.47 \\
3.33 \\
4.75\end{array}$ & $\begin{array}{l}99.73^{*} \\
100.00 \\
100.00\end{array}$ \\
\hline Average & 33.64 & 6.19 & 9.02 & 46.44 & 4.52 & $99.92^{*}$ \\
\hline
\end{tabular}

\begin{tabular}{|c|c|c|c|c|}
\hline \multirow[b]{2}{*}{ Grong } & \multirow{2}{*}{ Company Size } & \multicolumn{3}{|c|}{ Companies in Group } \\
\hline & & 1955 & 1960 & 1905 \\
\hline $\begin{array}{l}I \\
I I \\
I I I \\
I V \\
V \\
V I \\
V I I\end{array}$ & $\begin{array}{l}\text { Above } 10,000 \\
3,000-9,999 \\
500-999 \\
100-499 \\
50-99 \\
25-49 \\
\text { Under } 25\end{array}$ & $\begin{array}{l}1 \\
8 \\
1 \\
3 \\
2 \\
4 \\
2\end{array}$ & $\begin{array}{r}2 \\
9 \\
1 \\
7 \\
2 \\
5 \\
5\end{array}$ & $\begin{array}{r}2 \\
9 \\
4 \\
12 \\
7 \\
7 \\
5\end{array}$ \\
\hline
\end{tabular}

* report 10 percent of its sales for 1955 .

Source: Infra, Tabie B, Appendix III, p. 202 . 
that Bay Area firms employing over 1,000 persons held the largest percentage of sales directly to military markets of the federal government. The companies employing less than 1,000 persons conversely sold more to industrial markets. This seemed to give further indication that smaller companies tended to capltalize upon subcontracts issued by larger firms; however, the firms employing 50 and 100 persons did hold the largest percentage flgure for sales to space markets of the federal government.

Total averages for all companies contacted indicated that about 39.8 percent of sales went directly to the military-space market between 1955 and 1965. The decline of military sales from 34.0 to 31.3 percent between 1955 and 1965 was more than overcome by the increase in space sales from 3.8 to 9.8 percent. Thus sales to the mllitary-space market had a net increase of over 3.3 percent. Sales to the fecieral government for purposes other than military and space averaged about nine percent between 1955 and 1965. Industrial sales of the surveyed firms remained relatively stable as did sales to consumers, the two combined making up about 50.9 percent of total sales between 1955 and 1965. Actually, these two markets experienced a decline in sales between these years of slightly over 1.5 percent. 51 overall

5 Interestingly, these conclusions contradicted Lindner's study of electronics industry diversification which showed a marked tendency for electronles firms to diversjify away from military-space sales. 
sales distribution showed a marked influence by iniltaryspace markets and perhaps an overwhelming influence if subcontracting were determinable.

Data perhaps more Indicative of the trend of the SIC groups included in the survey was attained by computing an estimated percentage of employees actually supported by each market in each company and then in each SIC group. Table 25 presents general information concerning this analysis to include the number of firms and employees in existence In 1955, 1960, and 1965 by SIC classification and what percentage this was of total empjoyment in the industry. Table 26 reveals the percentages of employees and equivalent number of employees supported by the major markets by SIC groups and all surveyed companies. Because not all firms responded to the survey, less than 20 percent of the total Bay Area employees in SIC's 19, 30, 34 and 37 were included in participating companies. Consequently, Table 26 presents two total percentages of employees and equivalent number employees for all industries in each market. The flrst set of totals represents alI SIC groups particlpating in the survey, and the second sei represents only those SIC groups for which 15 percent or more total 1965 Bay Area employment was accounted. In most instances the data varled little; however, the latter totals will be discussed herein. In 1955 the military market supportea approximately 43.8 percent of the employees in the fabricated metals, 
TABIE 25

NUMBER OF COMPANTES AND 3969 REPORTED EMPJOYMENT OF SIO GROUPS SURVEYED COMPARED 20 DOUIVALENT BAY AREA TOSLLS FOR 1955. 1950, AND 2965

\begin{tabular}{|c|c|c|c|c|c|c|c|}
\hline \multirow[b]{2}{*}{$\begin{array}{l}\text { SIC } \\
\text { Group }\end{array}$} & \multirow[b]{2}{*}{ Year } & \multicolumn{3}{|c|}{ Connantes } & \multicolumn{3}{|c|}{ Embloyment } \\
\hline & & Survey & Bay Area & 总 & Survey & Bar Area & 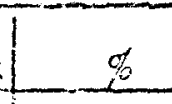 \\
\hline 19 & $\begin{array}{l}1955 \\
1950 \\
1965\end{array}$ & $\begin{array}{l}1 \\
1 \\
1\end{array}$ & $\begin{array}{r}6 \\
3 \\
--\end{array}$ & $\begin{array}{r}16.6 \\
33.3 \\
--\end{array}$ & $\begin{array}{l}2,500 \\
2,500 \\
2,500\end{array}$ & $\begin{array}{l}54,808 \\
18,6,5 \\
27,400\end{array}$ & $\begin{array}{r}4.5 \\
13.5 \\
9.2\end{array}$ \\
\hline 30 & $\begin{array}{l}1955 \\
1960 \\
1965\end{array}$ & $-\frac{1}{3}$ & $\begin{array}{r}24 \\
78 \\
100\end{array}$ & $\begin{array}{l}1 . \overline{3} \\
1.0\end{array}$ & $\begin{array}{l}25 \\
25 \\
25\end{array}$ & $\begin{array}{l}1,454 \\
1,700 \\
1,500\end{array}$ & .0 \\
\hline 34 & $\begin{array}{l}1955 \\
1960 \\
1965\end{array}$ & $\begin{array}{l}1 \\
i \\
1\end{array}$ & $\begin{array}{l}477 \\
523 \\
559\end{array}$ & $\begin{array}{l}.2 \\
.2 \\
.2\end{array}$ & $\begin{array}{l}3,800 \\
3,800 \\
3,800\end{array}$ & $\begin{array}{l}22,355 \\
24,729 \\
23,500\end{array}$ & $\begin{array}{l}17.0 \\
15.4 \\
16.2\end{array}$ \\
\hline 35 & $\begin{array}{l}1955 \\
1950 \\
1955\end{array}$ & $\begin{array}{l}3 \\
4 \\
4\end{array}$ & $\begin{array}{l}512 \\
517 \\
716\end{array}$ & $\begin{array}{l}.6 \\
.6 \\
.6\end{array}$ & $\begin{array}{l}4,550 \\
4,800 \\
4,800\end{array}$ & $\begin{array}{l}20,734 \\
19,781 \\
23,500\end{array}$ & $\begin{array}{l}21.7 \\
24.4 \\
20.4\end{array}$ \\
\hline 36 & $\begin{array}{l}1955 \\
1960 \\
1965\end{array}$ & $\begin{array}{l}11 \\
16 \\
28\end{array}$ & $\begin{array}{l}244 \\
248 \\
300\end{array}$ & $\begin{array}{l}7.6 \\
6.5 \\
9.3\end{array}$ & $\begin{array}{l}19,866 \\
34,219 \\
37,481\end{array}$ & $\begin{array}{l}17,931 \\
30,919 \\
40,300\end{array}$ & $\left\{\begin{array}{c}110.6^{\mathrm{b}} \\
110.7^{\mathrm{b}} \\
92.8^{\mathrm{s}}\end{array}\right.$ \\
\hline 37 & $\begin{array}{l}1955 \\
1950 \\
1965\end{array}$ & $\begin{array}{l}1 \\
1 \\
1\end{array}$ & $\begin{array}{l}135 \\
378 \\
181\end{array}$ & $\begin{array}{l}.7 \\
.6 \\
.6\end{array}$ & $\begin{array}{l}1,000 \\
1,000 \\
1,000\end{array}$ & $\begin{array}{l}15,525 \\
17,096 \\
14,100\end{array}$ & $\begin{array}{l}5.5 \\
5.8 \\
7.1\end{array}$ \\
\hline 38 & $\begin{array}{l}1955 \\
2060 \\
1965\end{array}$ & $\begin{array}{l}3 \\
5 \\
7\end{array}$ & $\begin{array}{r}75 \\
110 \\
111\end{array}$ & $\begin{array}{l}4.0 \\
4.5 \\
6.3\end{array}$ & $\begin{array}{l}745 \\
495 \\
820\end{array}$ & $\begin{array}{l}1,701 \\
2,553 \\
3,300\end{array}$ & $\begin{array}{r}8.2 \\
15.6 \\
24.8\end{array}$ \\
\hline 39 & $\begin{array}{l}2955 \\
1960 \\
1965\end{array}$ & $\frac{1}{3}$ & $\begin{array}{l}262 \\
225 \\
215\end{array}$ & $\begin{array}{r}.6 \\
.4 \\
1.4\end{array}$ & $\begin{array}{l}1,000 \\
1,000 \\
1,415\end{array}$ & $\begin{array}{l}5,991 \\
3,350 \\
3,300\end{array}$ & $\begin{array}{l}17.0 \\
33.3 \\
42.4\end{array}$ \\
\hline Total & $\begin{array}{l}1955 \\
1950 \\
1965\end{array}$ & $\begin{array}{l}22 \\
30 \\
46\end{array}$ & $\begin{array}{l}1535 \\
1082 \\
2102\end{array}$ & $\begin{array}{l}3.4 \\
3.5 \\
2.1\end{array}$ & $\begin{array}{l}32,851 \\
47,829 \\
51,831\end{array}$ & $\begin{array}{l}140,499 \\
118,953 \\
136,900\end{array}$ & $\begin{array}{l}23.4 \\
40.2 \\
37.8 \\
\end{array}$ \\
\hline
\end{tabular}

aSIC classirloations for survcyed firms were assigned by the Greater San jose Ghaber of Commerce and Lay

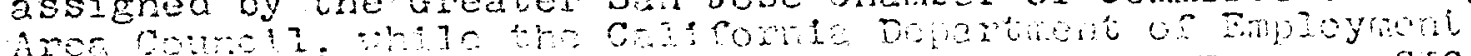

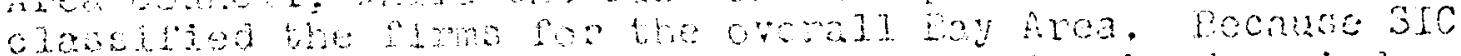

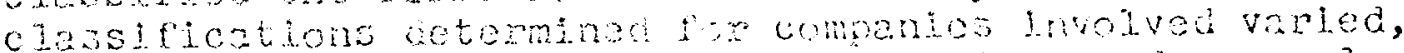

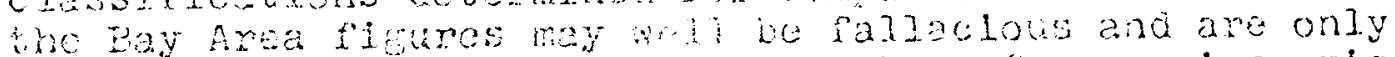
offered as an incication of the numer of compandes existing in aach Sre proup. Solaro conily is rot inclided in bay Area dase for 1565 .

DDiscrepancies the resuli of utilizing 1965 company employment data for sales years 1955, 1950, and 1965. Since doti for these years for surveyed companles was not aval Iable, empioyment for I 559 was used throughout the study.

Sources: Infra, Table B, Appendix II, p. 196; Table B, Appendix III, p. 202; and Californla, Department of Employment, Rescarch and Statistics Division. California Emiglovment and Payrolis in 1955: $A$ Study of Workor fand wacesi covered by the Calliomia linemployment Insurance Act Clasalfied by $18 \mathrm{~b}$ Inaustrir aid Count, hept. No. 127, 18 t TJuly, 1950T, and $\mathrm{pts}$. 330 and 260 for 1900 and 1965 . 
TABLE 26

ESTIMATED NUMBER OF EHPLOYEES SUPPORTED BY MAJOR MARKET SALES OF SURVEYED INDUSTRTAL FIRMS BY SIC INDUSTRY GROUP, AS A EERTENI OH TOTAI SURVEYED ENPLOYMENT,

\begin{tabular}{|c|c|c|c|c|c|c|}
\hline \multirow[b]{2}{*}{$\begin{array}{c}\text { SIC } \\
\text { Gxoup }\end{array}$} & \multirow{2}{*}{\multicolumn{2}{|c|}{ Percont }} & \multicolumn{2}{|r|}{1960} & \multicolumn{2}{|r|}{1965} \\
\hline & & & Pereent & $\begin{array}{l}\text { Employ- } \\
\text { oes }\end{array}$ & Percent & $\begin{array}{l}\text { Employ } \\
\text { egs }\end{array}$ \\
\hline $\begin{array}{c}39 \\
30 \\
34 b \\
35 b \\
36 b \\
37 \\
30 b \\
39 b \\
70 t a t \\
p(0)\end{array}$ & $\begin{array}{r}100.00 \\
2 \\
77.36 \\
41.76 \\
12.00 \\
20.34 \\
93.00 \\
47.05 \\
43.91 \\
\end{array}$ & $\begin{array}{r}2500 \\
2 \\
-5 \\
3520 \\
8064 \\
320 \\
29 \\
900 \\
15443 \\
12853 \\
\end{array}$ & $\begin{array}{r}100.00 \\
20.00 \\
73.33 \\
53.31 \\
32.00 \\
12.77 \\
95.00 \\
53.51 \\
53.38\end{array}$ & $\begin{array}{r}2500 \\
3 \\
37- \\
3517 \\
18242 \\
320 \\
63 \\
950 \\
25505 \\
22772 \\
\end{array}$ & $\begin{array}{r}100.00 \\
15.00 \\
47.25 \\
36.05 \\
27.00 \\
47.34 \\
68.09 \\
38.52 \\
35.57\end{array}$ & $\begin{array}{r}2500 \\
2 \\
1980 \\
13553 \\
270 \\
388 \\
053 \\
19950 \\
17134\end{array}$ \\
\hline $\begin{array}{c}19 \\
30 \\
340 \\
350 \\
300 \\
37 \\
300 \\
390 \\
T 0 t a 1 \\
T(b) \\
\end{array}$ & $\begin{array}{r}-- \\
a \\
6.59 \\
.25 \\
15.17 \\
1.14 \\
1.27 \\
\end{array}$ & $\begin{array}{r}-- \\
a \\
300 \\
52 \\
-\overline{2} \\
22 \\
-\overline{37} \\
374\end{array}$ & $\begin{array}{r}- \\
- \\
6.24 \\
5.69 \\
20.30 \\
- \\
4.91 \\
5.30\end{array}$ & $\begin{array}{r}-- \\
-- \\
300 \\
1947 \\
-- \\
100 \\
2347 \\
2347\end{array}$ & $\begin{array}{r}\cdots \\
\cdots \\
12.60 \\
13.62 \\
7.50 \\
16.67 \\
11.59 \\
12.43\end{array}$ & $\begin{array}{r}-- \\
-- \\
605 \\
5105 \\
-\overline{5} \\
236 \\
-6007 \\
6007 \\
\end{array}$ \\
\hline $\begin{array}{l}10 \\
30 \\
30 \\
300 \\
360 \\
30\end{array}$ & $\begin{array}{r}\ldots \\
\vdots \\
6.59 \\
6.78 \\
67.00 \\
\end{array}$ & $\begin{array}{r}-- \\
2 \\
300 \\
2337 \\
300 \\
\end{array}$ & $\begin{array}{r}-- \\
30.00 \\
8.33 \\
3.0 \% \\
47.00\end{array}$ & $\begin{array}{r}-- \\
1140 \\
400 \\
3358 \\
470\end{array}$ & $\begin{array}{r}2- \\
36.00 \\
7.32 \\
4.31 \\
7.00\end{array}$ & $\begin{array}{r}-- \\
7565 \\
351 \\
1615 \\
79\end{array}$ \\
\hline $\begin{array}{r}390 \\
390 \\
\end{array}$ & $\begin{array}{r}13.44 \\
-1.00\end{array}$ & $\begin{array}{r}29 \\
-10 \\
\end{array}$ & $\begin{array}{l}8.54 \\
4.00\end{array}$ & & $\begin{array}{r}6.52 \\
14.66\end{array}$ & $\begin{array}{r}53 \\
207\end{array}$ \\
\hline $\begin{array}{l}10 \operatorname{tal} \\
\mathrm{T}(\mathrm{b})\end{array}$ & $\begin{array}{l}7.1 \% \\
5.5 \%\end{array}$ & $\begin{array}{l}2 \\
1656 \\
\end{array}$ & $\begin{array}{l}7.21 \\
6.72 \\
\end{array}$ & $\begin{array}{l}3450 \\
2980 \\
\end{array}$ & $\begin{array}{l}7.01 \\
7.48 \\
\end{array}$ & \\
\hline $\begin{array}{l}1 y \\
30 \\
340 \\
350 \\
350 \\
37 \\
380 \\
30 \\
640 \\
610\end{array}$ & $\begin{array}{r}-- \\
a \\
9.67 \\
51.00 \\
21.00 \\
49.65 \\
1.00 \\
3.09 \\
3.26\end{array}$ & $\begin{array}{r}-- \\
a \\
-- \\
440 \\
10132 \\
230 \\
72 \\
20 \\
10054 \\
10554\end{array}$ & $\begin{array}{r}70.00 \\
-.0 \\
12.08 \\
37.01 \\
23.00 \\
57.57 \\
1.00 \\
20.0 \\
30.57\end{array}$ & $\begin{array}{r}-- \\
10 \\
=- \\
580 \\
12654 \\
210 \\
295 \\
130 \\
13549\end{array}$ & $\begin{array}{r}-- \\
75.00 \\
38.82 \\
53.03 \\
55.00 \\
38.50 \\
-50.54 \\
31.40\end{array}$ & $\begin{array}{r}-5 \\
12 \\
3803 \\
15120 \\
660 \\
326 \\
2 \\
18313\end{array}$ \\
\hline $\begin{array}{l}39 \\
30 \\
340 \\
35 \mathrm{~b} \\
35 \mathrm{~b} \\
37 \\
38 \mathrm{~b} \\
39 \mathrm{~b} \\
10 \mathrm{cI}\end{array}$ & $\begin{array}{r}-- \\
a \\
200.00 \\
-03 \\
.03 \\
-\frac{1}{37} \\
1.37 \\
11.60\end{array}$ & $\begin{array}{r}-5 \\
3800 \\
-\frac{-}{6} \\
-\frac{-}{2} \\
-\frac{2}{3808}\end{array}$ & $\begin{array}{r}10.00 \\
70.00 \\
.02 \\
. \overline{80} \\
-\overline{59}\end{array}$ & $\begin{array}{r}-2 \\
2660 \\
-\frac{7}{4} \\
-\frac{4}{4} \\
2673\end{array}$ & $\begin{array}{r}10.00 \\
64.00 \\
-\overline{0} \\
2.02 \\
.97 \\
-97 \\
\end{array}$ & $\begin{array}{r}-- \\
2 \\
2432 \\
-- \\
757 \\
-\frac{8}{8} \\
-- \\
\end{array}$ \\
\hline $\begin{array}{l}\text { TotaI } \\
\text { i (b) }\end{array}$ & $\begin{array}{l}11.60 \\
12.97 \\
\end{array}$ & $\begin{array}{l}3808 \\
3808 \\
\end{array}$ & $\begin{array}{r}5.59 \\
6.03 \\
\end{array}$ & $\begin{array}{l}2673 \\
2671 \\
\end{array}$ & $\begin{array}{l}6.18 \\
6.62 \\
\end{array}$ & $\begin{array}{l}3190 \\
3197\end{array}$ \\
\hline $\begin{array}{l}\text { Iitary- } \\
\text { Totai } \\
\text { T (b) }\end{array}$ & $\begin{array}{l}\text { ce Mark } \\
48.12 \\
45.08 \\
\end{array}$ & $\begin{array}{l}\text { rets, } A 11 \\
15817 \\
3237\end{array}$ & $\begin{array}{l}\text { SIC Grou } \\
58.03 \\
56.58 \\
\end{array}$ & $\begin{array}{l}27942 \\
25119 \\
\end{array}$ & $\begin{array}{l}50.29 \\
48.00 \\
\end{array}$ & $\begin{array}{r}25963 \\
23191 \\
\end{array}$ \\
\hline $\begin{array}{l}\text { Marke } \\
\text { Total } \\
T(b)\end{array}$ & $\begin{array}{l}\text { AII SI } \\
100.00 \\
100.00\end{array}$ & $\begin{array}{l}\text { C Group } \\
32825 \\
29365 \\
\end{array}$ & $\begin{array}{l}100.00 \\
100.00\end{array}$ & $\begin{array}{l}47834 \\
44316 \\
\end{array}$ & $\begin{array}{l}100.00 \\
100.00 \\
\end{array}$ & $\begin{array}{l}51808 \\
48310 \\
\end{array}$ \\
\hline
\end{tabular}

ence.

ano companies surveyed of this SIC group in exist-

based on 1955 employment of SIC group in Eay Area, more than 15 percent of the employment in the classification was included in the companles surveyed.

Calculated from: Infra, Table B, Appendix III, 
machinery, electrical machinery, instruments, and miscellaneous SIC industries. This percentage rose to 51.3 in 1960 and then declined to 35.5 in 1965. A lessening impact on these industries by military spending was evident; however, the addition of a growing impact of space spending tended to cushion the decline. The 45.0 percent of employees supported by the military-space market in 1955 had increased to 56.6 percent in 1960 and st1ll remained above the mid-fifties percentage in 1965 when it slipped to 48.0 percent. Thus, between 1955 and 1965, the military-space market supported approximately 49.9 percent of these surveyed industries. Sales to non-military and nor-space government agencies accounted for another 6.5 percent of Income, so total direct reliance upon government markets for these surveyed firms averaged about 56.5 percent of their sales. The consumer market accounted for only about 8.5 percent of sales over the decade and had, in fact, declined from 12.9 to 6.6 percent between 1955 and 1965 . The remainIng 35.0 percent average of the decade's sales were to industrial markets. The amount of this percentage which uItimately went to government markets was undeterminable. Yet, if 20.0 percent of the industrlal sales were subcontracts destined for government markets, the overall reliance of the surveyed firms upon government markets averaged around 63.5 percent of their sales. The militaryspace market alone received about 56.9 percent of their saies. 
The individual industries dealt with in the survey were found to have a relatively heavy reliance upon the milltary-space market for their sales. The miscellaneous or unclassified industries (SrC 39) led all other groups in rellance with an average of about 87.03 percent of their sales going to this market; however, only about 1,000 employees working for three firms were included among the survey respondents. The machinery industry (SIC 35) had an average 63.98 percent reliance upon the military-space market. In this classification some 20 percent of the employees in the industry were accounted for by the respondents, although many small companies were not included. The best coverage of the survey was for the electrical machinery Industry (SIC 36). Approximately 90 percent of the employees In the Industry appeared to have been accounted for and some 28 firms responded. This industrial group had an average of 44.01 percent sales to the military-space market for the three years covered.

Because of the variables existent in the calculations of the survey data, conversion of the percentages of sales to various markets into monetary impact may be misleading. Yet the percentages of sales to the varlous markets are indicative of general trends. One can hardly dispute that the military-space market was significant. Several firms of varying size had very close to a 100 percent rellance upon these markets--particularly in the machinery, 
electrical machinery instruments, miscellaneous, and, obviously, the ordnance classifications.

The two digit SIC classifications obtained from Walter Isard's data on unclassified prime contracts to firms in metropolitan areas provided additional indication of the significance of the military-space markets to industrial groups in the Bay Area. 52 When size of contracts let to Bay Area firms were estimated from Isard's compilations, the Impact on the surveyed SIC groups above was again evidenced with the exception of the miscellaneous sector (SIC 39). Again, however, SIC classification for varlous firms varies from year to year and survey to survey, so data was not directly comparable. In addition to the industrial groups dealt with above, other industrles were revealed to be heavy recipients of military-space contracts. Many of these groups received a surprisingly large percentage of the contracts reported by Isard (Table 27). The service industries (SIC's 70-89), for example, received about 47.6 percent of the some $\$ 1.1$ billion military awards let to the Bay Area in 1960, 8.2 percent in 1962, and 22.9 percent in 1964. During the latter year this sector was awarded about 25.6 percent of the combined military-space contracts let to the region's firms. This 25.6 percent of the wages and salaries to the 173,337 service industry employees according

52Supra, p. 117 . 
TABLE 27

PERCENTAGE OF TOTAL BAY AREA MILITARY CONTRACTS RECEIVED BY SELECTED INDUSTRIES: 1960,1962 , AND 1964

\begin{tabular}{|c|c|c|c|c|c|}
\hline SIC & INDUSTRY & 1960 & 1962 & 1964 & AVERAGE \\
\hline 19 & Ordnance \& Accessories.... & 3.5 & & 31.1 & 11.8 \\
\hline 20 & Food \& Kindred Products .. & & 13.6 & 5.0 & \\
\hline 28 & Chemicals \& Products .. & .6 & .8 & .5 & \\
\hline 29 & Petrol \& Coal Products & $7 \cdot 3$ & 20.2 & 7.4 & 11.6 \\
\hline 30 & Rubber Products........ & .1 & & .4 & .2 \\
\hline 32 & Stone, Clay, \& Glass ..... & & $x$ & .2 & \\
\hline 33 & Primary Metal Industries & & & .2 & \\
\hline 34 & Fabricated Metal Products & 2 & & .3 & \\
\hline 35 & Machinery $\ldots \ldots \ldots \ldots \ldots$ & & & & .7 \\
\hline 36 & Electrical Machinery & 6.9 & 15.6 & 11.0 & 11.2 \\
\hline 37 & Transportation Equipment & 21.5 & 25.6 & 6.1 & 17.7 \\
\hline 8 & Instruments & 5.6 & .9 & i. 2 & 2.8 \\
\hline $15-17$ & Contract Construction..... & 2.5 & 3.6 & 6.9 & 4.3 \\
\hline $41-49$ & Trans, Commo, \& Utilities. & $4 . \overline{4}$ & 8.1 & 5.3 & $6 . \overline{3}$ \\
\hline $50-59$ & Wholesale \& Retail Trade. & .8 & .8 & & \\
\hline & Service Industries ....... & 47.7 & 8.2 & 22.9 & \\
\hline
\end{tabular}

Source: Calculated from infra, Table A, Appendix IV, p. 209.

to the State Department of Employment SIC classification would total approximately $\$ 225$ million dollars--sume 1.6 percent of the region's personal income. In 1960 the ordnance industry obtained only 3.5 percent of the region's m1litary contracts, and this fell to .07 percent in 1962 . However, the largest share of military contracts went to this sector in 1964--31.1 percent. The approximately 24,300 ordnance industry employees could have, perhaps, attributed about $\$ 74,205,22$ of their wages and salaries in 1964 to military contracts--.5 percent of the Bay Area's personal 
income. 53 other industries gaining a significant percentage of the total mliftary contracts let to firms in the Bay Area included food and kindred products (SIC 20) with an average percentage for the three years of about 7.1, petroleum and coal products (SIC 29) with an average of about 11.6 percent, electrical machinery (SIC 36) with an average of about 11.2 percent, and transportation equipment (SIC 37) with an average of about 17.7 percent. The instruments, contract construction, and transportation-communications-utilities industries also shared a noticeable percentage of the contracts--a combined average of approximately 4.3 percent. An additional approach for analyzing defense impact was to determine the impact upon individual companies. Perhaps the most comprehensive method was to consult data published by the various firms being studied and to conduct personal interviews with the companies or request data by ma1l surveys, though companies were reluctant to respond; holvever, a thorough study of Bay Area defense-oriented Industries was beyond the limits of this paper. Yet, investigation of individual companies could not be altogether neglected. As noted in Governor Reagan's 1968 report on the state economy, it was obvious that a major change in the government's procurement program might have significantly

53calculations from data in infra, Tables $B$ and $C$, Append1x II, pp. 196 and 197; and Table B, Appendix III, p. 202. 
affected the employment and production of an individual company and might have had extensive repercussions on the local economy. 54 An indication of the flow of contracts to Bay Area companies was found, for example, in figures on procurement in 1956. Th1s data, released by the San Francisco A1r Force Procurement District, showed that $\$ 26$ million in contracts for part of FY 1956 was divided between sixteen local firms. Five of the firms accounted for $\$ 24.4$ million of this procurement by themselves. 55 Certainly, a sudden or unexpected contract adjustment could have seriously affected the welfare of any of these firms.

Some sources did release contract data for companies by location, and this Information was utilized herein. Unclassified prime defense-space contract data for Bay Area flrms is presented in Table 28. (More extensive flgures are found in Table B, Appendix IV.) The top ten defense contractors in the Bay Area in FY 1963 were awarded $\$ 745$ million dollars. Elght of these companies were found to be among the top one-hundred nationwide defense contractors. Two of these were universities probably engaged solely in $R$ \& $D$-Stanford and the University of California at Berkeley. Another, the Stanford Research Institute, was a nonprofit R \& D organization. Finaliy, the Lockheed Aircraft

54 Report of the Governor, 1968, p. 42.

55 Mercury, March 5, 1956. 
TABLE 28

TOP TEN BAY AREA DEFENSE-SPACE PRIME CONTRACTORS: FY 1963 AND FY 1964 (Thousands of dollars)

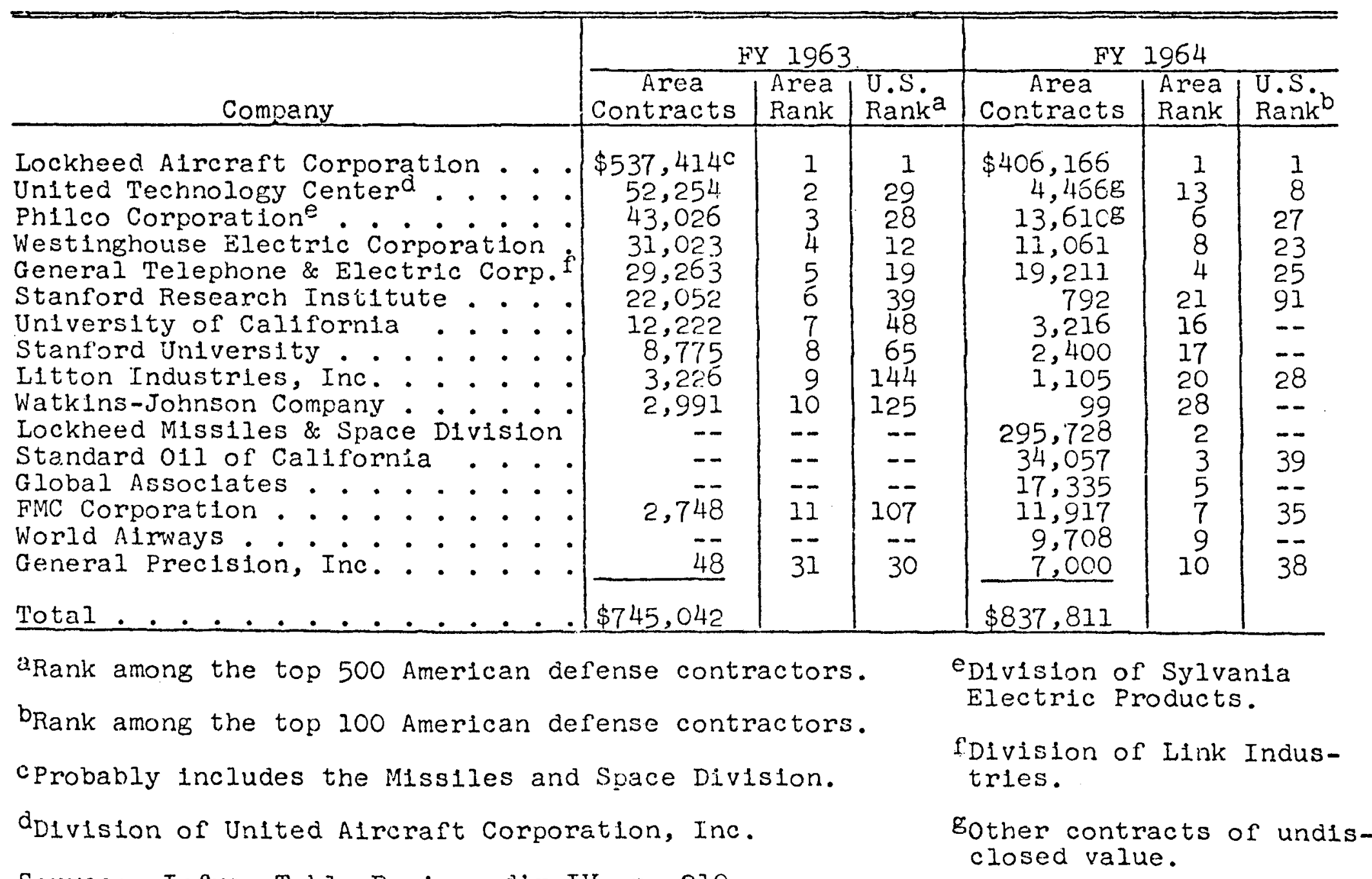

Source: Infra, Table B, Appendix IV, p. 210. 
Corporation (to include the Missiles and Space Division), the leading employer in Santa Clara County, accounted for 72.1 percent of the awards to these leading Bay Area contractors. In FY 1964, the top ten companies had changed somewhat, and their volume had risen to $\$ 837$ milition. Lockheed Alrcraft Corporation still led the other contractors in volume of awards. When the corporation's separately Ilsted Misslles and Space Division was included, this company accounted for 83.7 percent of the contracts recelved by the top ten. Only three of the remaining top ten companies for the previous year appeared in this category in 1964. Moreover, the aerospace companies which had dominated the leaders in FY 1953 were replaced not solely by more aerospace companies but by two air service compantes (Global Assoclates and World Alrways, Inc.), an oil company, and a traditional ordnance producing company (FMC). Also the three nonprofit $R$ \& $D$ organizations among the earlier top ten had been replaced by commerclal companies. The impact on the Bay Area of the contracts awarded to just these top ten companies was evident when calculated as a percentage of the region's personal income. In FY 1963, the $\$ 745$ milition received by these companies amounted to 5.8 percent of Bay Area personal income, and in FY 1964 $\$ 837$ milision accounted for 6.1 percent. The total contracts awarded to Bay Area firms for which data was available during FY 1963 amounted to $\$ 760.6$ mililon, 5.9 percent of 
the region's personal income. This equaled about \$206 per capita for the region and constituted 7.7 percent of the $\$ 2,656$ per capita net buying power. In FY 1964, $\$ 844.6$ mililon total awards was 6.1 percent of the area's personal income. 55 This totaled $\$ 222$ per capita and equaled about 7.9 percent of the $\$ 2,780$ per capita net buying power. Thus, the top ten companies seemed to have earned well above 90 percent of the contracts let to bay region firms. The addition of Identiflable subcontracts let to the Bay Area only ralsed the FY 1964 percentage to 6.3. Probably these were conservative figures, for the scurces may well have not reported all contracts recelved by Bay f.rea companies.

The data discussed so far presents an indication of regional defense expenditure impact; however, no overall conclusions have been reached. First, two more indicators of impact should be considered. The Bureau of the Census released a revealing report in 1966 concerning shipinents of defense-orlented industries from selected metropolitan areas, regions, and states. 57 This study and the location quotion method of analyzing basic manufacturing employment deserves attention.

56Personal income figures for the Bay Area are found In infra, Table E, Appendix II, p. 199.

57U.S., Department of Commerce, Bureau of the Census, Census of Manufacturers, 1963 (Washington, D.C.: Government Printing office, I956), I, SR2. 
The compliation and release of information concerning the value of shipments from defense-oriented industries was a significant step on the part of the Department of Commerce toward solving the problem of data avallability dealing with defense spending impact. Over a period of years this data should prove most useful, yet even the initial release was important. The census data indicated a larger Bay Area defense spending impact than other analyses. Earlier studies demonstrating that the San Jose SMSA was largely affected by defense expenditures seemed substantiated. The industries involved in the analysis by the Bureau of the Census employed 61,100 persons in the Bay Area in 1963--21.0 percent of the region's manufacturing employment and 6.1 percent of the total employment minus federal government employees (see Table 29). The total value of shipments from the defenseoriented Bay Area industries amounted to $\$ 1,389.6$ million-10.9 percent of the region's personal income. Shipments to the federal government equaled $\$ 1,155.5$ million--9.1 percent of the personal income. This percentage indicated quite an Increase in impact compared to the 4.9 percentage of personal Income of the unclassifled awards compiled by Isard for the Bay Area for 1964.58 While only 6.1 percent of the total employment was in defense-oriented industries, these industries accounted for approximately 9.1 percent of the region's

58 Supra, p. 116. 
TABLE 29

DEFENSE-ORIENTED SHIPMENTS FRON CALIFORNIA AND THE BAY AREA, $1963^{a}$

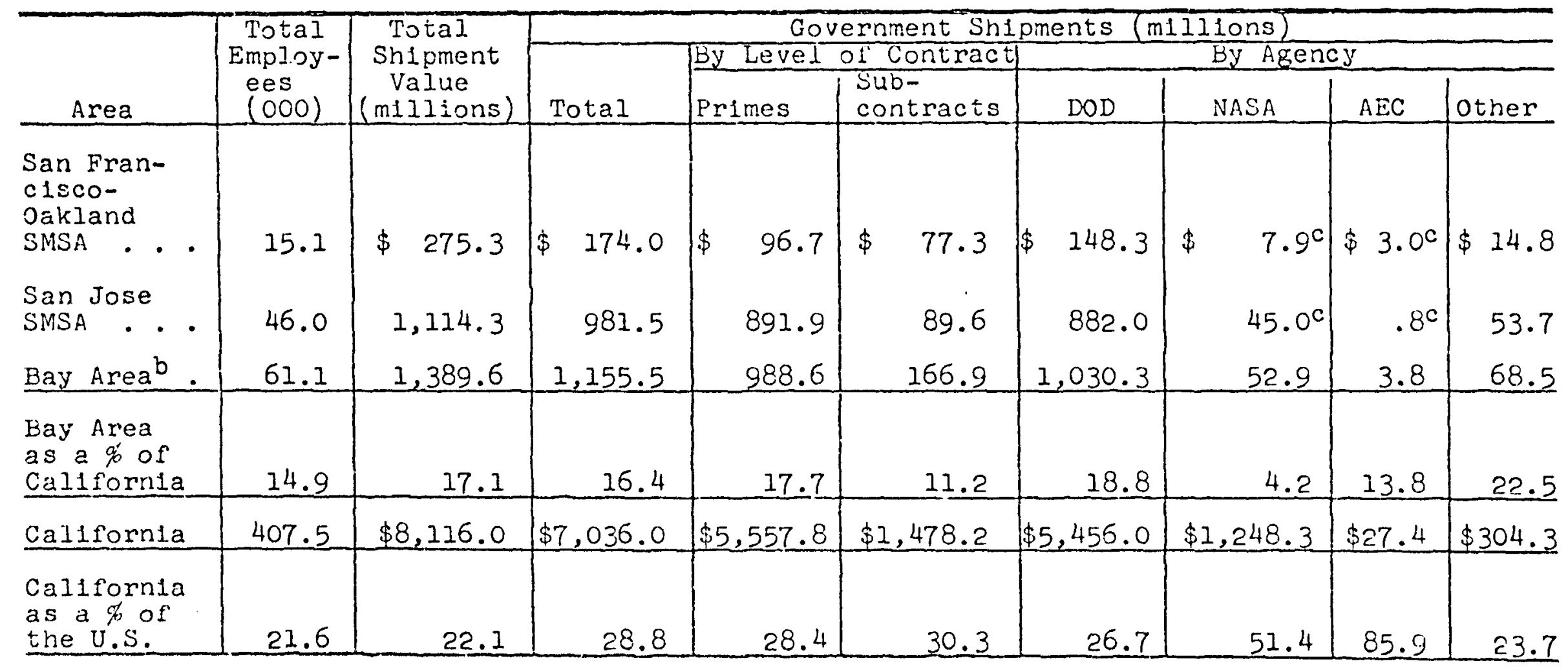

andustries included in analyis is were SIC's 1925, 3511, 3531, 3541, 3542, 3571.366 , $367,372,3731,3811,38211,38216,3831$, and 3861 .

binus data for Solano and Napa Counties.

CEstimated from value ranges provided by the Bureau of the Census.

Source: U.S., Department of Commerce, Bureau of the Census, Census of Manufacturers, 1963 (Washington, D.C.: Government Printing Office, 1966), 1, SR 2-11-13 and 17. 
personal income through sales to the federal government. Furthermore, while 21.0 percent of the employmant in manufacturing firms was in the defense-oriented industries, about 55.0 percent of the total wages and salarles paid to the Bay Area's manufacturing Industry employees could have been paid by the value of shipments to the federal government by the defense-oriented industries. In fact the value of these shipments amounted to about 83.2 percent of the industries' total shipments. Therefore, if 83.2 percent of the employment in these industries was supported by the shipments, approximately 27 percerit of the total wages and salaries paid to 21 percent of the employees of all Bay Area manufacturing industries could have been attributed to shipments to the federal government by defense-oriented industries. Census data also showed that the San Jose SMSA far exceeded the San Francisco-0akland SMSA in total shipments of defense-oriented industries and shipped about 20 percent less to the federal government firms based in the San Jose region. Approximately 51 percent of the manufacturing employment and 22 percent of total employment in the San Jose SMSA as compared to 21 percent and 6 percent respectively in the Bay Area was accounted for by defenseoriented firms. Finally, it was indicated that the Bay Area shared about 18.8 percent of shipments to the Department of Defense from California and, surprisingly, only about 4.2 percent of the state's shipments to NASA. The 
region's significance as a defense-industry complex was obvious.

The last analysis considered was based on the assumption by Charles Tiebout that, ". . If a given commodity is hlgnly specialized relative to the nation in the production of a particular commodity, the product is assumed to be an export item, e.g., automobiles from Detroit."59 The location quotient analysis assumes that the percentage of total national employment of an industry should equal the percentage of total local employment of that industry. Any excess of that percentage localiy would be export or basic industry employment.

$$
\frac{\mathrm{X}}{\begin{array}{l}
\text { total local } \\
\text { employment }
\end{array}}=\frac{\text { national employment in industry } A}{\text { total national employment }}
$$

$X=$ number employed locally in industry A to provide area needs.

A.n adjustment was possible, according to Tiebout, for productivity locally as compared to productivity nationally by using local and national value added data for each industry analyzed. However, this step was not used herein. Flnally, Tiebout noted that results using location quotients lnevitably tended to be lower than direct survey results; yet how much location quotients were lower was not known, so no adjustments could be made for this varlable.

59 Tiebout, Base Study, p. 59. 
Five industries, considered defense-oriented, were analyzed over the perlod 1950-1965 using location quotients. The aircraft and parts industry was found to have had no basic employment in the Bay Area; 1.e., this industry's local employment as a percentage of the region's total employment was less than the industry's national employment as a percentage of the nation's total employment. The instruments industry also showed negative location quotients for every year with the exception of 1964 in the San Jose SMSt when the analysis showed .03 percent basic employment. The shipbuilding industry, the region's most significart defense industry for many years, was shown to have had a declining basic employment percentage--from .49 in 1958 to . 11 in 1964 (the only years analyzed for this industry). The remaining two industries analyzed were shown to have had very sizable basic employment, rising rapidy during the 1950's to a peak in 1962 and then dropping off sldghtly. The ordnance industry (to which shipbullding was added for the years 19581964 ), had the highest growth rate in relation to the industry nationally and reached the highest level of basic employment in 1962--2.29 percent. The electrical machinery industry grew less rapidly in relation to the industry nationally, also reaching its highest level of basic employment in 1962--1.69 percent. Both industries, however, had extremely high location quotients in the San Jose SMSA. In 1952, the ordnance industry reached 13.60 percent, and the 
electrical machinery industry climbed to 11.66 percent.

The overall results of the location quotient analysis can be seen in Table 30. In 1950 basic employment for the Bay Area in the ordnance, electrical machinery, and instruments Industries was actually nonexistent. The San Jose SMSA, however, had a basic employment rate of 1.95 vercent or 1,189 workers. Gradually, between 1950 and 1956, the Bay Area location quotient became less negative until it reached a positive percentage indicating .59 percent basic employment (5066 workers) in 1957. Meanwhile, the San Jose SMSA stead1ly grew in basic employment and reached 9.40 percent (11,129 workers) in 1957. A steady increase in basic employment was experienced in both areas unt11 1954, when a setback was experienced. Yet the decline was brief, and by 1965 the basic employment had risen in numbers of employees al though the percentages of basic employment had continued to decline. It is obvious that the smaller geographic and population area of the San Jose SMSA had an extremely large location quotient in comparison with the Bay Area in general. Yet the San Jose region was an integral part of the entire Bay Area and should not be considered as completely autonomous. The results of the location quotlent were helpful in giving a wider perspective to the question of defense spending jmpact on the Bay Area, providing an indication of relative impact compared to the nation.

The overali 1mpact of defense spending on the Bay 


\section{TABLE 30}

COMBINED IOCATION QUOTIENTS FOR ORDNANCE, ELECTRICAL MACHINERY, AND INSTRUMENTS IN THE SAN JOSE SMSA AND THE BAY AREA, 1950-1965

\begin{tabular}{|c|c|c|c|c|c|c|c|}
\hline \multirow[b]{2}{*}{ Year } & \multirow{2}{*}{$\begin{array}{l}\text { U.S. } \\
\text { Total } \\
\text { Employment }\end{array}$} & \multicolumn{2}{|c|}{$\begin{array}{l}\text { \%otal } \\
\text { Employment }\end{array}$} & \multicolumn{2}{|c|}{$\begin{array}{c}\text { Bay Area } \\
\text { Employment }\end{array}$} & \multicolumn{2}{|c|}{$\begin{array}{l}\text { San Jose } \\
\text { Employment }\end{array}$} \\
\hline & & Bay Area & San Jose & Basic & Actual & \$B Basic & Actual \\
\hline $\begin{array}{l}1950 \\
1951 \\
1952 \\
1953 \\
1954 \\
1955 \\
1956 \\
1957 \\
1958 \\
1959 \\
1960 \\
1961 \\
1962 \\
1963 \\
1964 \\
1965\end{array}$ & $\begin{array}{l}2.15 \\
2.447 \\
2.78 \\
3.11 \\
2.78 \\
2.74 \\
2.82 \\
2.84 \\
2.74 \\
3.00 \\
3.10 \\
3.13 \\
3.28 \\
3.22 \\
3.11 \\
3.19\end{array}$ & $\begin{array}{l}1.11 \\
1.61 \\
1.93 \\
2.21 \\
2.01 \\
2.13 \\
2.68 \\
3.44 \\
4.14 \\
4.99 \\
5.57 \\
6.31 \\
7.00 \\
6.85 \\
6.28 \\
6.09\end{array}$ & $\begin{array}{r}4.11 \\
5.78 \\
5.88 \\
6.45 \\
7.00 \\
7.50 \\
8.98 \\
12.24 \\
16.76 \\
20.01 \\
22.18 \\
24.51 \\
26.15 \\
25.03 \\
23.07 \\
21.55\end{array}$ & $\begin{array}{r}-1.04 \\
-.86 \\
-.85 \\
-.90 \\
-.77 \\
-.51 \\
-. .14 \\
.59 \\
1.90 \\
1.98 \\
2.57 \\
3.17 \\
3.72 \\
3.62 \\
3.17 \\
2.90\end{array}$ & $\begin{array}{r}5066 \\
15798 \\
17291 \\
23611 \\
29735 \\
36608 \\
36687 \\
32970 \\
33787\end{array}$ & $\begin{array}{r}1.95 \\
3.30 \\
3.10 \\
3.32 \\
4.22 \\
4.76 \\
6.16 \\
9.40 \\
14.01 \\
17.00 \\
19.07 \\
21.37 \\
22.87 \\
21.81 \\
19.95 \\
18.35\end{array}$ & $\begin{array}{r}1189 \\
2332 \\
2335 \\
2586 \\
3432 \\
4329 \\
6406 \\
11129 \\
17372 \\
23214 \\
30283 \\
36924 \\
43149 \\
44038 \\
41642 \\
43781\end{array}$ \\
\hline
\end{tabular}

*Shipbuilding is included for the years 1958-1964.

Calculated from:

U.S., Department of Commerce, Office or Business Economics, 1967 Business Statistics: A Supplement to the Survey of Current Business (Washington, D.C: Government Printing Office, 1967), pp. 65 and 68; and infra, Tables B and C, Appendix II, pp. 196 and 197 . 
Area was increasingly significant after 1955, as it was for the entire state. Its Impact was not fully determinable. The California State office of Planning stated that in 1965 about 35 percent of the state's manufacturing employment was directly involved in production for defense-space use. "If the multiplier effects of manufacturing employment are taken Into account," the planning office continued, "then at least a third of the state's employment, and probably more, is directly and Indirectly dependent upon decisions made within the federal government." 60

The multiple effects of exogenous income in the Bay Area were most important during the 1950's and 1960's, and defense-related income comprised a significant portion of exogenous income. For example, in a 1965 study of a hypothetical defense reduction In California, the State offlce of Planning suggested that the reduction of one dollar in products from defense industries would result in a $\$ 2.57$ reduction of total wages and salaries in the state. 61 "A dollar of income from outside thus supports more than a

$60 \mathrm{California,} \mathrm{Department} \mathrm{of} \mathrm{Finance,} \mathrm{State} \mathrm{office} \mathrm{of}$ Planning, California State Development Plan Program: Progress Report and Summary Interpretations of Phase I Studies (Sacramento, February, 1905), p. 21 (Hereinal'ter referred to as Phase I Studjes). Impact of Federal Spending in Callfornia, p. II, notes that some economists estlinated that as many as one-half of California's jobs were attributable to defense and space activities.

\section{1 phase I Studies, p. 21.}


Area was increasingly significant after 1955, as 1t was for the entire state. Its impact was not fully determinable. The California State Office of Planning stated that in 1965 about 35 percent of the state's manufacturing employment was directly involved in production for defense-space use. "If the multiplier effects of manufacturing employment are taken into account," the planning office continued, "then at least a third of the state's employment, and probably more, is directly and Indirectly dependent upon decisions made within the federal government. "60

The multiple effects of exogenous income in the Bay Area were most important during the 1950's and 1960's, and defense-related income comprised a significant portion of exogenous income. For example, in a 1965 study of a hypothetical defense reduction in California, the State office of Planning suggested that the reduction of one dollar in products from defense industries would result in a $\$ 2.57$ reduction of total wages and salaries in the state. 61 "A dollar of income from outside thus supports more than a

${ }^{60} \mathrm{Cal}$ ifornia, Department of Finance, State office of Planning, California State Development Plan Program: Progress Report and Summary Interpretations of Phase I Studies (Sacramento, February, 1905), p. 21 (Hereinaiter rei'erred to as Phase I Studies). Impact of Federal Spending in Caljfornia, p. II, notes that some economists estinated that as many as one-half of California's jobs were attributable to defense and space activities.

$6 I_{\text {Phase I Studies, }}$ p. 21. 
dollar of total income," said economist Roger E. Bolton in 1966, "because the original dollar earned is raspent several times." 62 A study by the Department of Commerce suggested that approximately $\$ .50$ of each dollar of national income went to taxes, savings, and imports from forelgn countries in 1963, while the remaining $\$ .50$ was spent on consumption within the nation. The multiple effects of the consumption spending was defined as:

$\frac{1}{1-\begin{array}{l}\text { Proportion of income spent on locally } \\ \text { produced consumption of goods and } \\ \text { services }\end{array}}$

Thus, the multiplier for the nation was 2.0 ; $1 . e ., 1 / 1-.50$. "Other things being equal," continued the report, "the income multiplier for any local area will be smaller than the nationai muitiplier, since many of the goods and services consumed in the local area are imported from other areas of the country." Therefore, if half of the consumption goods of an area were provided locally, \$.25 would have been spent on local consumption in each spending round, and the multiplier would have been 1.33 ; 1.e., $1 / 1$ - .25. Large, diversifled metropolitan areas would have, it was assumed, a multiplier of about 1.8. In each consumption or spending round, then, $\$ .44$ of each dollar of local income would have been spent on locally provided goods and services. Conversely,

62Roger E. Bolton, Defense Purchases and Regional Growth (Washington, D.C.: The Brookings Institute, 1966), 
a smaller less diversified area would have had a 1.3 multiplier, equal to spending about $\$ .23$ of each dollar of local income on locally provided goods and services. 63

The importance of the multiplier could be seen by applying it to a hypothetical company. An electronic component firm relying entirely on an outside market and employing several hundred persons paid $\$ 2$ militon in wages and salaries in a given year. The total impact of these wages and salaries was not simply $\$ 2$ million. If the flrm was located In a large metropolitan area, the total impact would have been $\$ 3.6$ million ( $\$ 2$ million in wages and salaries or employee income times 1.8). If the firm were in a small metropolitan area, the total impact would have been only $\$ 2.6$ million ( $\$ 2$ militon in employee incone times 1.3 ). Actually the impact could have been greater in both cases, If it were possible to isolate and evaluate all spendine rounds.

The most frequently used form of the multiplier analysis used to analyze regional impact was the "base theory" or exogenous income theory. This theory supposed that the only autonomous element of regional income to be considered was that derived from exports outside the area. 64

63U.S., Department of Commerce, Economic Development Administration, Industrial Location as a Factor in Regional Economic Development (Washington, D.C.: Government Printing of'ice, 1967), pp. 44-45.

$$
64 \text { Ibid., pp. } 46-47 \text {. }
$$


In case, an area's total income equaled $\$ 125$ million of which $\$ 100$ militon were basic or exogenous and $\$ 25$ million were non-basic. To measure the income impact of a $\$ 1.00$ increase in basic income, one would look at the ratio of basic to non-basic income. In this case 1 to would have been 4 to 1 ( $\$ 100$ milizon to $\$ 25$ milizion). The addition of $\$ 1.00$ in basic income would then add another $\$ .25$ of non-basic or local income. 65 The formula should be:

Total income increase $=$

Increase in basic income $\mathrm{X}$

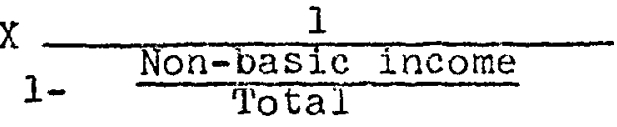

$$
\$ 1.25=\$ 1.00 \times \frac{1}{1-\frac{\$ 25 \text { mil1ion }}{\$ 125 \text { mil11on }}}
$$

Application of the multiplier analysis to the Bay Area was possible although limited, for estimates of the percentage of basic employment or income were available only from two sources--a 1959 Department of Commerce study and a 1961 market analysis by the State of Californla. ${ }^{66}$ The Bay Area was obviously a large region in all respects, but the diversity of the economy was not clear. The San FranciscoOakland SMSA was considered widely diversified, yet the San Jose SMSA was rather narrowly diversified. Thus the choice

65Tiebout, Base Study, pp. 59-60.

${ }^{66}$ Supra, p. 69. 
of a multiplier was not easily made. It was estimated, using Department of Commerce data, that 51.7 percent of the Bay Area manufacturing employment and 40.1 percent of total Bay Area employment worked for basic Industrles or served outside markets. The State of California analysis indicated that 69.6 percent of the area's manufacturing employment and 34.5 percent of the total employment served outside markets. Because of the basic nature of much of the manufacturing Industry in the region and the conversely local nature of many of the nonmanufacturing industries, the latter figures were used for the multiplier analysis of the Bay Area.

Application of the multipiler analysis to Bay Area income between 1950 and 1965 using the constant non-basic or local income percentage of 65.5 revealed an approximate multiplier of 2.89. While this was obviolisly above the 2.0 national multiplier suggested by the Department of Commerce, Bay Area economic studies have indicated some degree of uniqueness in the region's structure. The exogenous portion of the personal income was substantial at 34.5 percent; however, the degree of self-sufficlency and interdependency of the Bay Area was also very high.

The importance of the multiplier to defense-space spending in the Bay Area was great (Table 31). For example, in 1963 the estimated \$216 million wages and salaries paid as a result of defense-space sales by the region's $R$ \& $D$ industries increased to $\$ 624 \mathrm{million}$ when exposed to the 
TAEST 33

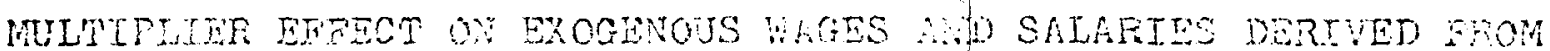

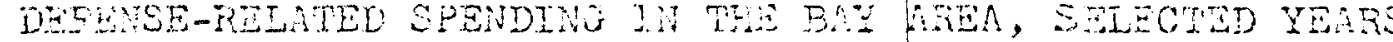

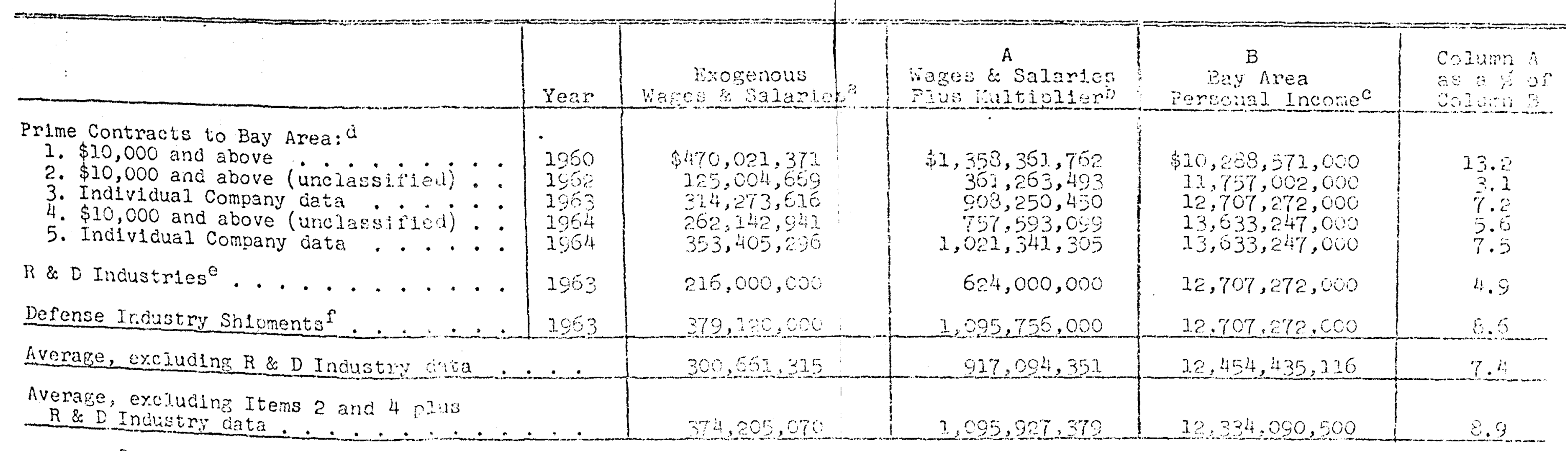

pereente wt was estimated that 35 weent of total detense industry shipments went tnto weges and salaries. This sens

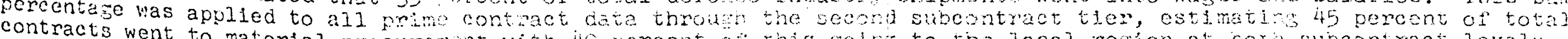

Bay Area multiplier equaled 2.80 .

Infra, Table E, Appencitx is, p. 199.

dSurra, Table 20, p. 127; ans Table 20, p. 340.

esupra, pp. 107-108. fsuesa, Table 29, p. 144. 
multiplier. As a result, about 4.9 percent of the Bay Area's $\$ 12.7$ bililon personal income was attributable to research and development by the DOD and NASA. The defense shipment figure for 1963 by the Census of Manufacturers had revealed that $\$ 1,083.2$ million in Bay Area sales had gone to the fecieral government. It was estimated that approximately 35 percent of the amount or $\$ 379,120,000$ was funded into salaries and wages in the region. 67 The multiple effect of this income was then 8.6 percent of the Bay Area personal income--about $\$ 1,095,756,800$. The multiple effect of the prime deiense contracts let to the Bay Area as reported by Walter Isard's research varied from 13.2 percent in 1960 to 3.1 percent in 1962 and 5.6 percent in 1964. The last two $y$ tars, however, included only the efrect of nonclassified contracts. The data collected from individual company contracts let to Bay Area firms offered a higher total than Isard's data for 1964, the multiple effect amounting to 7.5 percent of Bay Area personal income. Yet the 1903 total of individual company contract data was less than the total derived from Census data, the multiple effect reaching 7.2 as opposed to 8.6 percent of the regior's personal income. The average multiple effect of data provided by ali the above sources, except $R \& D$, amounted to 7.4 percent of Bay

67 Estimated percentage based on data for the $R \& D$ industry, supra, pp. 107-108. 
Area personal income-- $\$ 917$ million of $\$ 12,454$ million. When discounting sources from which only unclassifled contract data was available for 1962 and 1964, the average multiple effect was 8.9 percent of the personal income--\$1,095 mililon of $\$ 12,334$ mililion--for 1960, 1963, and 1964. While completely accurate data was not available, it was possible to conclude conservatively that defense-space spending contributed approximately eight percent of the region's personal income. This percentage would have amounted to about $\$ 502$ million of the $\$ 6,277$ million Bay Area net buying power in 1955, $\$ 735$ milition of $\$ 9,198$ in 1960 , and $\$ 946$ mililion of $\$ 11,829$ million in 1965 . About $\$ 198.00$ of the average per capita net buying power of $\$ 2,478.00$ for these years and approximately $\$ 529.00$ of the average household net buylng power of $\$ 7864.00$ was attributable to defense-space spending In the Bay Area.

The dependency of the Bay Area upon defense spending was apparentiy not exorbitant, if the evidence analyzed is accepted. The existence of defense-space $R$ \& $D$ industries In the region was noticeable and had a calculable economic impact of around five percent of the regional personal income. Analysis of prime contracts coming into the Bay Area and the subcontract flow of those primes revealed widely divergent results, yet the calculable economic impact seemed to have amounted to about nine percent of the regional personal income. It should be noted, however, that 
measurement of the economic Impact of subcontracts let to Bay Area firms from the outside was not made; for, unlike the state as a whole, the subcontract flow out of the area was not necessarily equal to the inward flow. Estimated calculations at the state level, using the same criteria used in appraising the economic impact of prime contracts In the Bay Area, indicated that between 1960 and 1965 approximately 10.8 percent of the California's personal income was attributable to defense-space spenaing. Yet the criteria for the state level was undoubtedly not the same as that for the Bay Area. While some comparative value was evidenced, this percentage was misleading. The application of a 2.0 multiplier to the average of prime contracts entering the state revealed an impact equaling 17.9 percent of California's personal income. Other sources indicated even higher percentages. 68 Nonetheless, the calculable Bay Area income dependent upon defense-space spending could be termed signiflcant, even without benefit of comparison to another area. Certainly any comprehensive cutback of defense-space income would be widely felt and no doubt undesirable.

$68_{\text {Regional Effects of Government Procurement, }}$. 22 , for example, suggested that the impact of def'ense-spending In California totaled $\$ 18.8$ billion or about 35.9 percent of the state's persorial income. 
VI. THE IMPACT OF DEFENSE SPENDING IN THE BAY AREA

"More than half of the new manufacturing employment added in the San Francisco area between 1950 and 1960 was defense reiated," according to a State office of Planning Report in 1965.1 While not as substantial as defense related industrial growth in the Los Angeles and San Diego area, the impact in the Bay Area could not be discounted. The areas of the fastest population growth were also those with the fastest growth in defense-related industry. The four counties with the greatest amount of defense spendirg were Los Angeles, San Dlego, Santa Clara, and Sacramento, respectively. If orange County and Los Angeles County were consiciered together, these same counties led the state's population growth, in the same order. 2 Since the growth of the Bay Area, along with the other regions, was significantly affected by defense-related industrial Erowth, a reduction in defense spending could have similarly hurt the area. Such a possibility presented real evidence of the true impact of defense spending on the Bay Area economy. Varlous national studies have investigated the

\footnotetext{
$I_{\text {Phase I Studies, }}$ p. 33. Th1s would equal, perhaps, 50,000 workers.

2Phase II Report, p. 174.
} 
impact of hypothetical defense spending reductions. In 1962, for example, the federal government relsased data based upon a gradual reduction in defense spending. over a thirteen year period, from 1965 to 1977, defense expenditures would have been reduced from $\$ 56.1$ billion to $\$ 10.9$ bilition. To compensate for anticipated economic dislocation, the study proposed concurrent increases in total United States contribution to international disarmament programs, such as inspection and policing, from nothing to $\$ 7.1$ billion and increases in NASA and the Atomic Energy Commission (AEC) programs from $\$ 4.1$ bilition to $\$ 10.9$ billion. The overall reduction would have amounted to $\$ 32$ bilition- $-\$ 14.8$ billion during the first three years, $\$ 6.8$ blilion during the second three years, and $\$ 10.4$ billion during the last seven years. 3 Application of the same reduction and compensation to the Bay Area would have resulted in approximately a 6.4 percent reduction in the 1965 area personal income for the first three years-about $\$ 323.5$ million doliars of exogenous income. If continued growth in other sectors of the economy were retained, the reduction might not have been too harmful to the local economy, but the loss of 6.4 percent of the excgenous income (the personal income when the multiplier

3U.S., Arms Control and Disarmament Agency, Economic Impact of Disarmament (Washington, D.C.: Goverument Printing office, January, T962), pp. 23 and 27 . 
is applied) would have certainly retarded general growth in other sectors. Over the thirteen year perioc the approximate 46.8 percent reduction in defense-related income would have caused an estimated 13.4 percent reduction in Bay Area exogenous and personal income--about $\$ 675.9$ million In exogenous income and about $\$ 1,959.7$ million in personal income. Compensation for this loss in other industries obviously would have to be substantial and well-tlmed to circumvent any serious economic dislocation.

In a study by Wassily Leontief, professor of economics and director of the Harvard Economic Research Project, the impact of a 20 percent reduction in 1958 defense spending was calculated. Unlike the above study, no compensatory spending in the arms control field was calculated. Instead, a 1.8 percent increase in consumption spending was estimated. Because of the product differences between military and civilian goods and services and corresponding wages and salarles, however, the total wages and salaries pald in production for the military were assumed to have been 21 percent higher than those in clvilian production. Hence, $a \$ 7.6$ billion ( 1.8 percent) increase in civilian demand would have been necessary in offsetting the \$ó. 8 bilizon reduction in defense spending. California, Leontief estimated, would have lost 1.85 percent of her total employment positions, experienced a .54 percent increase in clvilian orlented employment, and a total of 
2.39 percent of the state's workers would have been displaced and have had to find new employment. Among the nineteen regions studied, California was highest in the loss of total jobs and total displacement and lowest in the net Increase of civilian oriented jobs. It was further estimated that the state would have experienced a net loss of $\$ 267.5$ million in non-household direct civilian labor earnings-10.8 percent of the total. Additionally, an estimated $\$ 322.59$ million of the $\$ 11,198$ million in labor earnings of state civilian and military employees of the Department of Defense would have been 1ost. A net loss of $\$ 590.1$ million out of $\$ 7,396$ million direct labor earnings would have been experienced by California--a loss of about 8.0 percent. 4 Application of the study's data to the Bay Area was impossible, yet just the 10.8 percent loss in non-household direct civilian labor earnings would have resulted in an estimated loss of about $\$ 500$ milion dollars in 1958.

The impact of defense reductions was, obviously, very difficult to determine. The best guide for estimating impact was analysis of an actual reduction, and the Bay

4 Vietnam Spending, II, pp. 689-90, 695-96, and 722 . A more recent study by Leontief, presented in Vietnam Spending, I, pp. 245-47, dealt with the effects of a \$19bilion cutback that might have resulted if the Vietnam conflict had ended in 1967. California would have faced serious economic problems, according to Leontief, experiencing a net decline of 3.7 percent in total employment. 
Area had experienced a reduction during the early 1960's. 5 What has been called moderate to severe fluctuations in the defense industry occurred nationwide between 1953 and 1964. The development of nuclear weapons and delivery systems had reached an advanced stage known sometimes as "overkill." This development plus a change in international relations ushered in the beginning of a de-emphasis in milltary output; and, coupled with the signing of the 1963 partial nuciear test-ban treaty, a defense spending decline was experlenced. 6 According to the federal government, national spending àropped off from a 1962 high of $\$ 53.3$ billion to about $\$ 50.0$ billion during the succeeding three years. Actual calendar year Department of Defense expenditures aropped in 1964 to 49.3 blilion from $\$ 50.1$ billion, while buaget figures rose to $\$ 51.2$ billion in 1964 and aropped to $\$ 47.4$ billion in $1965 .^{7}$ In California, awardea annual contracts dropped somewhat as might have been expected. The Increase in California's contracts from the federal government peaked at $\$ 5.9$ billion in 1962 and began to drop the next year to a low of $\$ 5.1$ billion in 1964 . The succeding

5unfortunately, thorough analysis of actual reduction experience was not availabie. Good information pertaining to defense reduction experiences and attitudes in New Jersey is in Small Business Conversion... Hearings, pp. 211-50, passim. Application of these findings to the Bay Area, however, was impractical.

6Lindner, "Diversification Progress," p. 1. IInfra, Table D, Appendix I, pp. 192. 
years then experienced the increase evident at the national level, probably because of the greater United States involvement in Vietnam. ${ }^{8}$ Wh1le the decline was not extremely large, according to budgetary and contract figures, the reaction and results in the Bay Area as well as the nation were significant.

Between January, 1963 and the end of 1964, approximately 30,000 engineers and scientists plus an additional 100,000 support personnel were la1d off throughout the United States. 9 In the Bay Area about 1,800 engineers and sclentisis were laid off between January 1, 1964 and March 31, 1965--about 8.0 percent of the total in the region. A total of some 6,000 Bay Area defense industry personnel were dismissed, triggering the lay off of about 4,000 employees In commercial companies. "The defense layoffs," stated Professor Raj P. Loomba of San Jose State College, "seem [ed] to have resulted in a chain reaction which caused engineer and scientific layoffs by non-deferse companies." Defense layoffs, he added, occurred primar1ly between January and August, 1964; whereas non-defense firms dismissed 67.8 percent of those employees let go between September, 1964 and March, 1965. The statewide layoff total, according to Loomba, amounted to 26,400 workers; however, a California

8supra, Table 19, p. 113.

GEngineering Employment, p. 17. 
State Assembly report stated oniy 13,600 workers were laid ofi. 10 Nonetheless, Joomba's findings were ignificant.

The lay offs in the Bay Area had created "considerable alarm," according to a San Jose Mercury-News publication. The period between 1959 and 1963 had been, continued the publication,". . a period of extensive, seemingly uncontrolled growth while government contracts were plentiful and jobs abundant." However, in 1964,". . a plateau was reached in which budget cutbacks meant fewer contracts." II The decline in contracts brought ". . a fight for survival," according to one anonymous electronics manufacturer. "For us," said another electronics industry executive, "this Is the same thing as disamament."12 There was simply not enough business, and the loss was certainly great. Professor Loomba reported that 57 percent of those laid off were earning $\$ 10,000$ or more per annum. The loss of the salaries of only the engineers dismissed in Sunnyvale totaled $\$ 7,000,000$ annually in take-home pay. When lay off's of

10R. P. Loomba, "A Study of the Re-employment and Unemployment Experiences of Engineers and Scientists Laid off in 62 Aerospace and Electronics Companies in the San Francisco Bay Area during 1963-65," Proceedings of the National Symposium on Stabilization of Engineering and Scientific Employment in Industry (San Jose, California: Manpower Research Group, Center for Interdisciplinary Studies, San Jose State College, 1966), pp. 9-10. For statewide lay off figures, see Impact of Federal Spending in California, $p .12$.

1lMarket Memo, August, 1965, pp. 1-2.

12 Mercury, December 6 and 7, 1963. 
support personnel were consldered, the annual take-home loss was about $\$ 20,000,000.13$

An unusually large number of contracts had been coming into the Bay Area because of the quality and quantity of engineers and scientists in the area, according to one source, and the lay offs were forcing these talented workers to leave the region. 14 Loomba, who questioned 876 of those engineers caught in the lay offs, ascertained that 61.6 percent of the engineers obtained new jobs in the Bay Area. While this percentage indicated some resiliency in the local economy, he noted that the new jobs offered lower salarjes than those obtainable outside the region. Indeed, 26 percent of his sample had to leave California to find re-employment. While only 54 percent of the sample had to leave defense work for new positions, 78 percent had to accept considerably different types of work to be re-employed. Finally, it was observed that 17 percent of those remaining in defense work had to leave the state for re-employment, whereas only about 9 percent of those who switched to commercial work left the state 15

13R. P. Joomba, An Examination of the Engineering Profession (San Jose, Callfornia: Mianpower Researcn Croup, Center for Interdisciplinary Studies, San Jose State College, 1968), pp. 41-42.

14 Engineering Employment, p. 19.

15Loomba, "A Study of Re-employment," pp. 20-22. 
Loomba concluded that it would not be difficult for engineers and scientists to shift from defenso to commerclal work, as 54 percent of his sample had done so without retraining. Furthermore, he suggested that, if more $R$ \& $D$ were done by commercial companies, the problem would be even smaller. ${ }^{16}$ Perhaps this observation is significant, yet englneers probably did not anticipate leaving their field. It seems true that engineers expected to move from company to company quite frequently. In fact, an electronics eng1neer interviewed by the writer suggested that changing companies frequently to work on worthwhile projects was becoming more desirable, for the experience enhanced the record of the individual. 17 In any event, suggested Wllilam Redmond, head of the state employment agency, ". . . those who remain unemployed are those who lack the educational qualifications, are over the usual retirement age, or for other reasons cannot be matched with specialized requirements

16Ibid., p. 26. Impact of Federal Spending in California, pp. 19-20, seems to support the deficiency in commercial $R$ \& $D$. It notes that in commercial enterprise about 28 percent of the employees are administrative and scientific, whereas 53 percent of the defense-space industry employees fall into this category. See also, California, Department of Industrial Relations, Division of Labor Statistics and Research, Trends in Aerospace and Federal Government Employment (Sacramento, January 28, 1964), p. 3.

17 Robert B. Small, private interview held at San Jose State College, San Jose, California, April, 1969. See also the comments of Eugene Rittenhouse, President, Western College Placement Association, in Engineering Employment, p. 94 . 
of job openings."18 If this contention were true during stable economic periods, how much it could hare been magnifled during unstable periods remalned unanswered. At least there had been some indication that specialized personnel could find re-employment with some ease. The conversion by companies from defense to commercial production was much more difficult to estimate, as will be discussed further in this chapter.

The actual Bay Area decline during 1963 and 1964 was probably. less than had been feared at the time. Overall manufacturing employment did seem to drop by 1,000 employees between 1964 and 1965, and a decline was experienced in several defense related Industries (see Table $B$, Appendix II). Yet population continued to grow, personal income increased consistently from $\$ 11.7$ million in 1962 to $\$ 14.6$ million in 1965, and net buying power also rose. Even Santa Clara County experlenced constant growth in these areas. Nonetreless, the apprehension at even a slight decline was significant. Fears were widespread that the 1964 decline In $R$ \& $D$ contracts was very serious, since these contracts were generally followed by production contracts. Hence, the reductions in 1963 and 1954 might have had rather

18Englneering Employment, p. 28. Robert B. Small concurred that the less competent personnel were those who do not find quick re-employment or leave the field. 
long-range repercussions. 19

There were, in fact, some minor repercussions. A slowdown in reglonal housing construction was attributed to aerospace employment losses, ut1lity companies experienced less than normal expansion, and the service and trade industries witnessed some decline in business. 20 A comparison of the San Jose SMSA defense reductions to those experienced by San Diego between 1958 and 1962 appeared in a Bay Area real estate journal in 1964. It suggested that, while a substantial defense industry decline would cause losses in construction and in the rest of the economy, ". . the catastrophic loss of all types of jobs which is sometimes - feared would not occur." 21 Indeed, by late-1964 the situation seemed improved, and by 1965 it was stated by one local newspaper publication that ". . a rebirth of Santa Clara County industry is evident as it is once again receiving a substantial share of avallable contracts... those announced in the San Jose Mercury and News have a combined valuation of nearly $\$ 3.5$ billion."22 Within another year it

19"Paradox in the West," Federal Reserve Bank of San

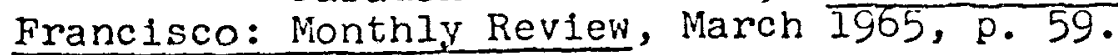
pp. $10-11$.

20 Ibid.; and Loomba, "A Study of Re-employment,"

21John W. Cone, "Employment Trends in the San Jose Mietropolitan Area," Northern California Real Estate Report (3d Quarter, 1964), 29.

22 Market Memo, August, 1965, p. 2. 
was announced that recruiters for the defense-space Industries reported that qualified people were more difficult to find.23 The reductions had ended, and prosperlty seemed to have returned--if, indeed, it had ever ceased. The Governor's 1968 economic report unconvincingly noted that the resurgence had been caused by increased orders for commerclal airplanes, a greater demand for sophisticated weapons, and the enhancement of United States Involvement in Vietnam. 24 Speculation as to the real impact of reductions would continue.

over the years both pessimism and optimism were expressed concerning the effects of defense spending changes In California and the Bay Area. The Wall Street Journal noted in 1965 that any economic slowdown in California would be felt throughout the nation. The 1964 housing slowdown in California, for example, was perhaps the main part of the national slowdown. Cutbacks in defense spending to California particularly hurt firms outside the state who did their subcontracting with California firms; for example, Baird-Atomic, Inc. of Cambridge, Massachusetts lost 400

\section{Revjew, JuIy, 1966, p. 136 . \\ 23FederaI Reserve Bank of San Francisco: Monthly \\ 24 Report of the Governor, 1958, p. 27. Karl G.} Harr, Jr., piesident of the Aerospace Industrial Association, noted that". ". most of the rise is die to the sales of commercial aircraft," in Bank of Californla, Pacific Coast Markets and Business, May, 1966, unpaginated. Report of the Governor, 1968, p. 32, notes only a 17 percent rise in commercial aircraft construction employment as opposed to an 83 percent rise in government aircraft construction employment between 1565 anà 1967 . 
employees between 1963 and 1964 as a result of California setbacks.25 In California speculation was eran more foreboding. A 1963 San Francisco Federal Reserve Bank report stated: "A sharp cutback in military and space expenditures would have far-reaching effects on the Twelfth District economy. . . "26 James Gillies of the University of California at Los Angeies had noted even earlier that ". . If the aircraft industry were to reduce its output substantially, the results in the economy would extend far beyond unemployment in that one industry. . . "27 Leaning toward the positive side of the issue; however, Governor Reagan suggested in 1968 that the alrcraft industry was too commercially oriented to suffer signiflcantly from defense cutbacks. Rather the smaller ordnance and electronics industries would be most adversely affected. 28

others, to be sure, were more optimistic. Sidrey Sonenblum suggested that the economy of California in 1965 was already shifting away from manufacturing. Even if a defense reduction came, California was favored, he believed, with ". . . the facilitles and manpower needed for production in those sectors and industries which are likely to show

25The Wall Street Journal, January 12, 1965, p. 1. 26Federal Reserve Bank of San Francisco: Monthly Review, February, 1960, p. 33 . 27Metropolitan California, p. 10. 28Report of the Governor, 1958, pp. 32-33. 
rapid growth in the future."29 Another optimist, orvilie $\mathrm{F}$. Poland of the University of California, observed in 1963 that, because of the diverse local economy, the Bay Area was not ". . highly vulnerable to the vagaries of the market." Unlike Detroit, which has its automobile industry, and Seattle with her alrcraft industry, the Bay Area was flexible. "However, the continued expansion of electronics and other industry related to the space and defense programs will increase their importance to the local economy." Cancellations and obsolescence could create severe dislocation in the Bay Area. But he hastened to add that other industries were also growing. 30 John Rubel also jolned the ranks of the optimists in 1965, when he wrote that continued stability in defense expenditures was most probable. While increases might not be at a high rate, the nation could and probably would afford a high defense expendlture level. 31 Finaliy, however, another note of pessimism was entered about the same time by economist Robert Arnold, who suggested that major economic adjustment would certainly have to occur in the event of defense cutbacks. Nonetheless, he too reverted to reassurance. "California is not likely," he

29 Hirsch and Balsden, California's Future, p. 15. 30poland, Economic Trends, pp. 4 and 24-25.

31John H. Rubel, "Economic Implications of Changing Federal Expenditures," In Hirsch and Baisden, California's Future, p. 20. 
added, "to experience a precipitous decline in defense or space spending . . . ."32

The rhetoric of optimism and pessimism, however, had existed for some time and would continue. Meanwhile, the usually vague and sometimes very real threat of defense reductions prompted further discussion. What should be done to soften defense cutbacks when they do become necessary? Several recommendations were made. E. J. Mosbaek suggested that defense industries did not necessarily need subsidation to withstand reductions. Unlike those industries subject to sudden large shifts--agriculture, for example, with its subsidies, and air travel, with 1 ts substantial mall cargoes-the defense industry would most $11 k \in$ ly have accurate forewarnings to preclude the need for subsidation. 33 on the other hand, the United States Arms Control Agency claimed that three methods used successfully after World War Two should be planned to offset cutbacks: tax reductions; expansion of public clvilian expenditures through schools, urban development, and transfer payments; and lower interest rates and reserve requirements. 34 With these views in mind,

32-Robert K. Arnold, "Potential Source of California's Future Growth," in Hirsch and Baisden, California's Future, pp. $24-25$.

33Mosbaek, "Reductions in Defense Expenditures," p.50. 34U.S., Arms Control and Disarmament Agency, The Economic and Sócial Consequences of Disarmament: U.S. - Reply to the Inquiry of the Secretary ceneral of the Undted Nations (Washington, D.C.: Goverinent Prjnting Office, Warch, 1962), pp. 9-10. 
Sonenblum suggested that tax reductions or increased government spending would make little difference on total employment in the nation as a whole. Yet, he said, ". . . It makes a considerable difference in terms of types of skills that will be required, the types of goods and services that will be produced, and the types of needs that are satisfled." Tax cuts would be felt by increased consumer purchases, resulting in a demand for new clerical, sales, and service skills. Government civilian expenditures, however, would make an impact in fields that would emphasize demands for professional skills employed in the defense-related industries. Such flelds might include urban renewal, education, and pollution control. 35

Other planning suggestions were on a different level. Paul Crappuchettes of Litton Industries, for example, recommended that the Department of Defense give extensive relocation assistance to those defense industry specialists laid off by contract cancellations. Furthermore, DOD should cease cancellations at its convenience. ${ }^{36}$ Professor Loomba

35Hirsch and Baisden, California's Future, p. $13 . A$ committee of the California State Assembly concurred in IG65, in Impact of Federal Spending in California, p. 21, that new educational techniques; mass-transportation systenis; application of advanced technology to agriculture, resource development, medical science, and other pursults could casily absorb the attention of the so-called aerospace industry.

36paul W. Crappuchettes, "The Stabilization of Eng1neering Employment by Correction of the Factors Producing Instability," Proceedings of the National Symposium on 
echoed this same view, adding that DOD should stop giving short-range contracts so as to provide stability, and eng1neers should organize to prevent sudden lay offs. 37 Still another suggestion came from Mosbaek, who proposed that making data available to specific geographic areas would place upon the residents of the areas the responsibllity for formulating the policies to meet reduction impact in their areas. However, George Jensen rebutted Mosbaek. He recognized that information on defense reductions was indispensable for planning, but would likely not be used by the communities. 38

Varied and provocative were the recommendations for limiting the impact of defense reductions. Attention was focused on one of these which Frank Stedman perhaps best introduced for Bay Area consideration:

The specialization in electronic components makes the area far less vulnerable to sifits in government procurement policy than areas with one large final contractor. Marly companies have such a broad range of products that they can shift from one missile system to another or from military to civilian production with relative ease. 39

However, considerable debate raged about this view, because

Industry (San Jose, Cal1fornla: Manpower Research Group, Center Ior Interdisciplinary Studies, San Jose State College, 1966), p. 90 .

37Loomba, An Examination, pp. 49-53.

38 Mosbaek, "Reductions in Defense Experditures," p. 52; and Jensen, "Defense Expenditures: A Comment," p. 81. 39 Stedman, "The California Peninsula," p. 48. 
of disagreement concerning defense-industry diversification abilities. In fact, discussion of diversification was less than positive.

It was often stated, by those claiming that the growth of defense-oriented industries during the 1950's and 1960 's was not a worry, that conversion to commercial production had been proven easy at the conclusion of World War Two. They contended that the same steps could easily be taken again. Yet the situation was not as similar as might have been supposed. Conversion after World War Two had generally been a problem of reconversion--returning to the production of previously produced commercial goods. The manufacturers knew that it was to be a short-run problem. "Even so," noted the Arms Control Agency, "not all defensegoods manufacturers succeeded in converting to non-defense production after World War Two and the Korean conflict." 40 In contrast to World War Two and even Korean War defense production, a significantly larger share of defense production during the late-1950's and 1960's was performed by highly specialized contractors. Many of their products bore no resemblance to clvilian items, and many of these contractors had never experienced production problems in the commercial market. As W1lliam Baldwin noted, ". . for many of these companies, there [was] no reconversion problem 
as such, because they had never 'converted' from clvilian production in the first place."41 on Decembe $=6,1963$, the San Jose Mercury reported one Bay Area executive as saying that the industry had been nurtured in an environment in which rellability and quality were far more important than price. "We're not equipped," he added, "to sell to the commercial market where cost is a big factor. . . ." Finally, comparison to the World War Two conversion experience was less than accurate because the latent consumer demand resulting from several years of short supply did not exist during the 1950 's and 1960 's. 42

Conversion was not considered impossible, but few believed it would be easy. The defense industries would have found it impractical to diversify internally, suggested Governor Reagan in 1968. Rather, he continued, they would have to convert through merger with and acquisition by established commercially-oriented firms. Therefore, diversification and eventual conversion would have been a very gradual process. 43 others suggested that conversion--even

41William L. Baldin, The Structure of the Defense Market, 1955-1964 (Durham, North Carolina: Duke University Press, 1967), p. 12, quoting Stanford Research Institute, "Industrial Adjustments to Shifts in Defense Spending," In U.S., Senate, Committee on Labor and Public Welfare, Selected Readings in Employment and Manpower (Wasington, D.C.: Government Printing office, IG64), II, 700.

42 Impact of Federal Spending in California, p. 19. 4Report of the Governor, 3968, p. 52. 
diversification--would have to be guided by government. Senator William Proxmire of Wisconsin noted 1n 1967 that defense industries would turn easily to a "systems analysis" approach in the fields of pollution, urban development, ano mass transportation. Such conversion plans did seem to hold promise, yet Charles L. Schultze, Director of the Federal Bureau of the Budget, replied that working with the mult1tude of local governments would be a major roadblock in such pursuits. There would have been no single source for contracts in these new fields, as DOD had been for defense work. 44 Nonetheless, it remainea an alternative to total commercial conversion, and it was observed in 1965 that some firms were turning to these new noncommercial flelds. 45 Diversification was perhaps forced upon Bay Area defense companies durling the early 1960's as a result of the contract declines of that perlod. In Lindner's 1967 study, it was observed that military sales had declined in 50 firms from 70 to 55 percent of total sales between 1961 and 1965. While the Bay Area firms still relied heavily on the mllitary market for over half 1 ts business in 1965, Lindner's study revealed a falrly widespread trend toward some diversification. As was noted earlier, however, this diversification was not totally toward the clvilian market.

44 Vietnam Spending, I, pp. 60-61.

45seymour Melman, Our Depleted Soclety (New York: HoIt, Rinehart, and Winston, 1955T, p. 218. 
While a 15 percent decline in sales to the military market did occur, there was a seven percent increase in sales to the space market and a one percent increase in sales to other government markets. Thus diversification to clvilian markets--i.e., Industry and consumers-amounted to seven percent, and it was assumed that there was not an increased trend in accepting defense-space subcontracts from the Industrial market. 46 In 1968 the San Jose Mercury polnted out several diversification attempts in Bay Area defense firms. The Lockheed Missiles and Space Company was divers1fylng within the military market. In the non-military market the firm was initiating projects in petroleum, education, hospltals, and law enforcement. Philco-Ford had started projects in sewage treatment, water systems, and rapid transit; Sylvania Corporation was in highway planning and water resources; and United Technology was working in garbage aisposal and pipelines. One of the earliest Bay Area defense firms, Varian Associates, was observed to have reduced military sales as a part of total sales from 80 percent in 1963 to 40 percent in 1968. However, the article added that the diversification, beginning as a result of the 1963-1965 recession, was ". . . not substantial enough yet to provide any big hedge against future downturns in defense

46Lindner, "Diversification Progress," pp. 38-42; and supra, pp. $126-127$. 
spending. " 47

Indeed, it was during the years immediately following the 1963 to 1964 defense spending decline that serlous efforts were made toward meeting the threat of future cutbacks. Perhaps the most significant step taken was that announced by California Governor Edmund $G$. Brown at a symposium concerning the state's future economic growth held at the University of California at Los Angeles in November, 1964. Brown seemed to have recognized the problem, when he observed:

- . 37 percent of our manufacturing industry is concentrated in ordnance, alrciaft, electrical, and instrument production. All are vulnerable to cutbacks and phaseouts in the federal government's space and defense programs, as we have seen in the Navajo pfogram in 1.955 and the Skybolt program of two years aco.

Brown then proposed a program designed to utilize the talents of the aerospace industry to solve social problems facing California residents. The industry, he said, would be given contracts by the state government to study transportation problems, design a system to improve collection of statistical data concerning diseases and educational requirements, study the problem of the criminally and mentally 1.11, and research the problems of waste manazement. An Advisory Panel on the Aerospace and Electronics Industries, composed

47 Mercury, october 27, 1968.

48Edmund G. Brown, "A Systems Engineering Approach to Community Problems: A Calieroria Experiment," In Hirsch and Eajsden, California's Future, p. 41. 
of business, academic, and government representatives, was established during the same year to study the problems posed by shifts in defense spending. Furthermore, Brown prompted organization of a Seminar on Industry Planning to Meet Shifts in Government Demand, which met in San Francisco and Los Angeles for off-the-record discussions by union, business, government, university, research, and civic group representatives. As a result, important steps had been taken by California to determine the capabilities of the aerospace industry in applying its talents to nondefense 1ssues and in preparing for the impact of defense cutbacks on the region's economy. 49 "Governor Brown's announcement," said economist Murray Weldenbaum, ". . . is the most signiflcant development that has yet occurred in the whole defense adjustment field." 50

While Brown's program was designed to show the way for further defense industry investments in clvilian programs and furtiner government spending in this area, industry balked and no government funds followed the initial contracts. Frani W. Lehan, vice-president of Aerospace General Corporation in EI Monte, noted in 1966 that there were no substantial follow-up funds; and since the defense business

49Ibid., pp. 42-43; President's Committee, Report, pp. $41-42$; and Engineering Employment, p. 9.

50Murray $L$. Weidenbaum, "The Federal Government's Role in Defense Cuiback Adjustment," in Hirsch and Baisden, California's Future, p. 37. 
picture had brightened, ". . our industry has to do the things that the country wants done."51 Perhaps what Lehan meant was that his industry had to engage in the enterprises that brought a profit. In any case, funds dwindled, and Governor Brown was reported to be in hopes of acquiring federal money to continue the program. Furthermore, he was reported to have said that, if he could win a third term In office, the program could feasibly overcome hurdles against it in the state legislature. 52 When Ronald Reagan became governor, the program was all but cast aside. The new governor announced in 1968 that industry people did not feel that applying funds to solutions of social problems was a good alternative for absorbing slack in defense-space cutbacks. It was simply too difficult to sell such projects to the community, so activity in these fields would remain token. 53

Diversification without the government's assistance, though, remained slow. As late as 1969 , it was observed that the larger, dominant defense firms were tending to hold entrenched positions in defense work and that competitive,

51 Quoted in, Harold D. Watkins, "California Effort is Key to Growth Area," Aviation Week and Space Technology, February 7 , 1966, pp. 79-81.

52Ib1d., pp. 81-82. See also, Missiles and Rockets,

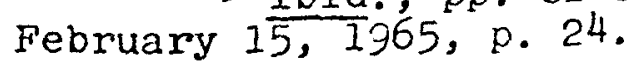

53. Report of the Governor, 1968, p. 52 . 
formally advertised bidding for contracts was less frequent. 54 Wrile the number of firms performing an overwhelming percent of their work in defense-space programs was not extremely large, even those large firms doing less than half of their business with DOD and NASA conducted that work in separate defense product divisions or departments. As far as the problems faced, these divisions were almost the same as purely defense-oriented companies. 55 The general trend in the defense industry seemed to have been to delay diversiflcation. Melman suggested that, perhaps, senior management and technical personnel in these firms did not really want to conslder conversion. Their lives had been spent becoming speclalists in the military market, and nowhere in the clvilian market did they see prospects of the billion dollar sales that were possible under the relatively insured conditions of DOD and NASA. "These men," he added, "are unsure of the occupational position and, to allay their doubts, they have devoted themselves to seeking ways to extend the milj.tary market." 56 Professor Loomba of San Jose State College continued along this line of thought, noting that many companies found little motivation toward diversification,

54U.S., Congress, Joint Economic Committee, Subcommittee on Economy in Government, Report: The Economics of pp. $4-5$.

55Melman, our Depleted Society, p. 218.

56 Ib1d., p. 217. 
as an excess of company personnel were retired military personnel or aircraft and missile designers. ". . These individuals," he concluded, "are not capable of leading their companies successfully into commercial markets."57 Consequently, the debate over diversification and the only visible answer to the defense-industry's vulnerable position in the economy seemed at a stalemate.

In California and the Bay Area, the problem seemed partlally recognized. Yet the hopeful program launched by Governor Brown had fallen by the wayside. The nori-standardized nature of the defense-space industry's products, the hlghly skllled and technological labor requirements of the industry, and the contract-project nature of the industry's market had all created powerful and mutually reinforcing forces for high geographic concentration. California and the Bay Area had experienced this very phenomenon. The sclentific talent which had grown in California largely because of World War two provided the leadership making Califorria a logical place for defense spenaing. The industrial base in research and development, electronics,

57 Engineering Employment, p. 22. That many retired military personnel found new jobs in defense industries had been fairly well substantlated by government investigation. For example, the House Armed Services Committee found in 1960 that ". . . 72 leading rilitary contractors employed 1,426 former high-ranking military officers "[in 1959], including 251 former generals and admirals." Quoted in Carl Marzani and Victor Perlo, Dollars and Sense of Disarmament 


\section{6}

and aircraft production provided the logical framework for further defense spending. The international scene after World War Two seemingly provided the need for ever-increasing expenditures. Between 1940 and 1950, the number of eng1neers increased 89 percent throughout the nation. Yet in California, this group of professionals, who were to be the basic working group of the defense-space industry, increased 131 percent. Between 1950 and 1960, while the national increase aropped to 64 percent, it grew in California to 147 percent. 58 clearly, the growth of this professional group illustrated the impact of defense-space spending on California. Estimates placed the dependency of Calfornda upon defense spending at somewhere around 20 percent of the state's personal income, and in the Bay Area tine dependency factor was about 10 percent of the region's personal Income. Inconsequential change was seen in the future, and virtually no fear of reduced defense spending was apparent. While it was pointed out that the defense irdustries were dependent on political decisions, it was also observed that It was unlikely that defense spending would change. 59

As a result, the thirty years following the outbreak of World har Two had provided a most profitable period of economic growth for California and the Bay Area. While

\footnotetext{
p. 112 .

58Shapeio, Howell, and l'ombaugh, Exploratory Study, 59poland, Ecoromic Trends, F. 24.
} 


\section{7}

somewhat aware of the vulnerability of their industrial base, reslcients of the Bay Area and much of the rest of California did not seem to have considered the possible ramifications of their reliance upon that base. Although there may have been some consclousness of the problem in the Los Angeles area, elsewhere the tranquility of life continued. Yet it was apparent that Bay Area residents, at least, had something in common with their southern California neighbors. The economic changes wrought by World War Two had added a new chapter to the economic history of all parts of Callfornta. 


\section{APPENDIX I \\ UNITED STATES GOVER:MENT EXPENDITURES}

Table

Page

A. Geographic Distribution of Defense Contracts, Three Perlods............ 189

B. GNP or Expenditure and Government Purchasing,

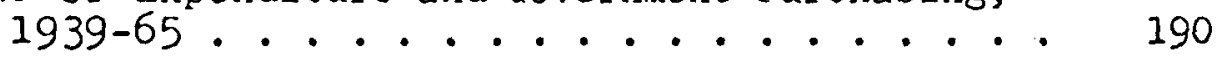

C. Percentage Distribution of Federal Expenditures During Major Wars .......... 191

D. United States Defense Experditures, 1950-1965 . 192

E. Department of Defense Procurement and Research and Development Expenditures, by Program,

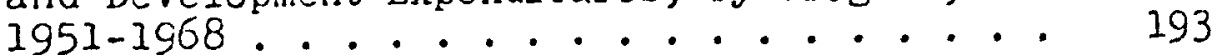


GEOGRAPHIC DISTRIBUTION

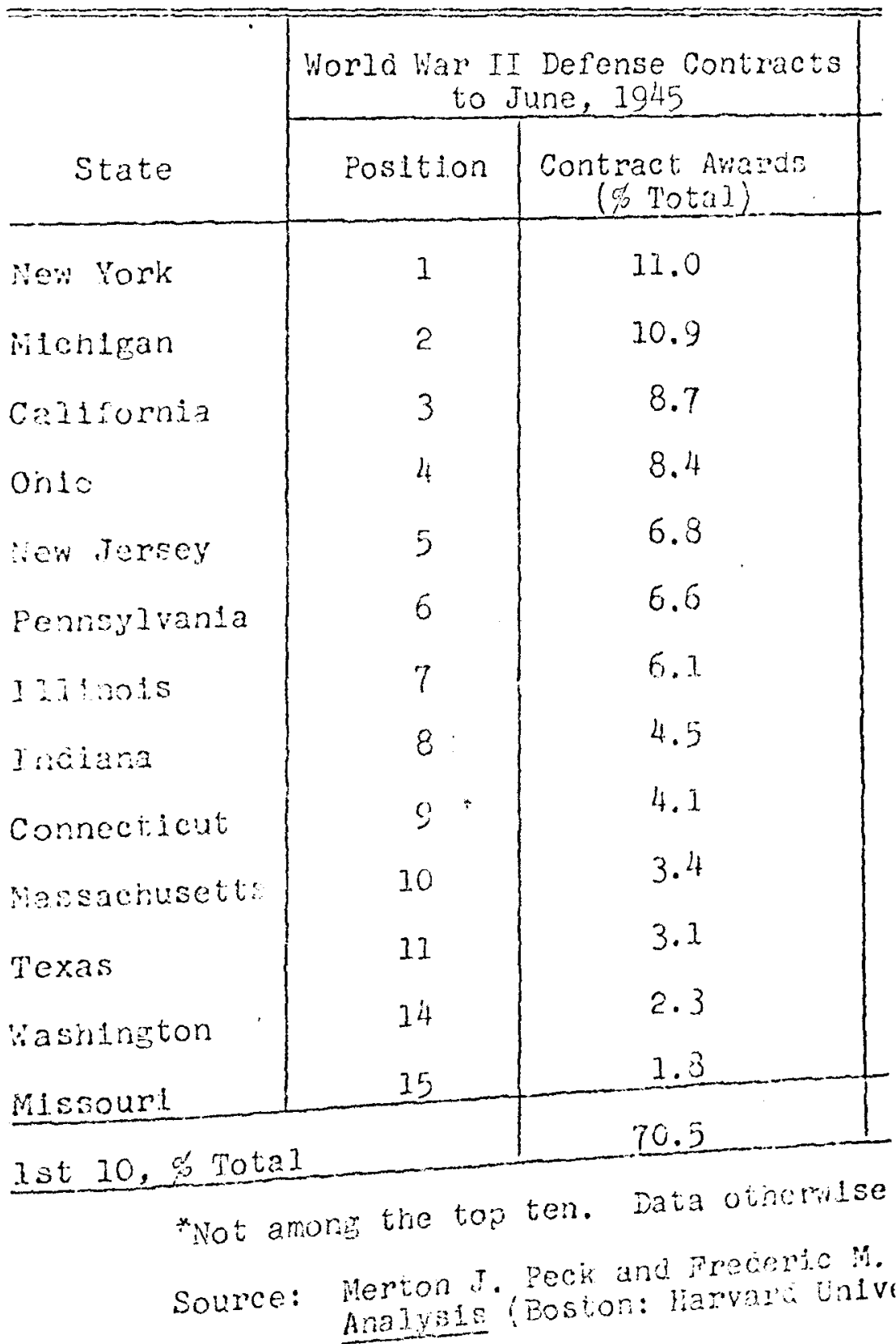


GNP OR EXPENDITURE AND G:

(In

\begin{tabular}{|c|c|c|c|c|c|c|c|}
\hline$y \cos$ & 1930 & 1940 & 1941 & .1942 & $29+3$ & 20.44 & 3945 \\
\hline $\begin{array}{l}\text { Porsonel bon- } \\
\text { Sumpion } \\
\text { Expenditunes }\end{array}$ & 107.6 & 73.9 & 81.9 & 89.7 & 100.5 & 1008 & 1217 \\
\hline $\begin{array}{l}\text { Gross enlonte } \\
\text { Domestio }\end{array}$ & & & & & & & \\
\hline $\begin{array}{l}\text { Expendibro } \\
\text { Net Forotra }\end{array}$ & 9.3 & 13.2 & 18.1 & 9.9 & 5.6 & 7.7 & .20 .4 \\
\hline $\begin{array}{l}\text { Luvestmentos } \\
\text { Covernmon }\end{array}$ & .9 & 1.5 & 1.3 & -.2 & -2.2 & -2.1 & -1.4 \\
\hline 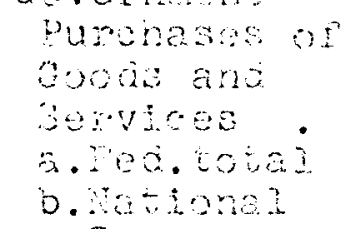 & $\begin{array}{r}13 \\
5.2\end{array}$ & $\begin{array}{r}14.2 \\
6.2\end{array}$ & $\begin{array}{l}24.8 \\
16.9\end{array}$ & $\begin{array}{l}59.7 \\
52.0\end{array}$ & $\begin{array}{l}88.6 \\
81.2\end{array}$ & 90.5 & $\frac{2}{7+9}$ \\
\hline - Besungy & 2.3 & 2.2 & 13.6 & 49.6 & 80.4 & & 3.9 \\
\hline$a: p$ & 91.2 & 100.6 & 125.8 & 159.1 & 30.5 & 221.4 & 213.6 \\
\hline
\end{tabular}

\begin{tabular}{|c|c|c|c|c|c|}
\hline Xeer & 1956 & 1257 & 2855 & 1059 & 198 \\
\hline 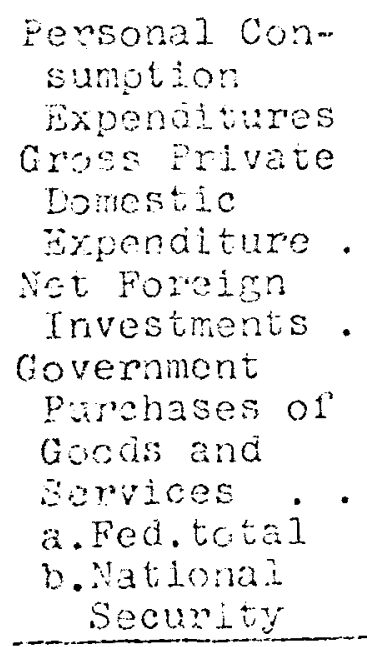 & $\begin{array}{r}79.0 \\
45.7 \\
40.1\end{array}$ & $\begin{array}{l}86.5 \\
49.7 \\
4: .4 \\
\end{array}$ & $\begin{array}{l}93.5 \\
52.6 \\
44.8\end{array}$ & $\begin{array}{l}97.2 \\
53.6 \\
46.2\end{array}$ & $\begin{array}{l}99 . \\
53 . \\
45 .\end{array}$ \\
\hline $\mathrm{FP}$ & 419.2 & 440.8 & $4 n i_{4} .5$ & $492 \cdot 1$ & 502 \\
\hline
\end{tabular}

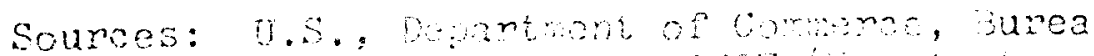

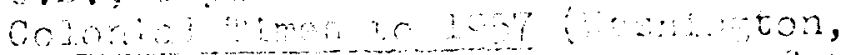

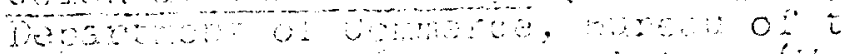

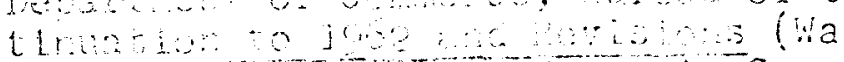
Q.0., $1969, \ldots 2$ 
TABLE C

PERCENTAGE DISTRIBUTION OF FEDERAL EXPENDITURES DURING MAJOR WARS

\begin{tabular}{|c|c|c|c|c|c|c|}
\hline & Total & Military & Veterans & Interest & Fore1rn & C1011 \\
\hline \multicolumn{7}{|l|}{ War of 1812: } \\
\hline Prewar . & 100.0 & 48.0 & .9 & 33.5 & -- & 17.6 \\
\hline Postwar: & & & & & & \\
\hline lst $5 \mathrm{yrs}$. & 100.0 & 46.3 & 7.3 & 28.6 & $-\cdots$ & 17.8 \\
\hline and 5 yrs. & 100.0 & 38.6 & 9.8 & 28.3 & $-\cdots$ & 23.3 \\
\hline \multicolumn{7}{|l|}{ Civil War: } \\
\hline Prewar . & 200.0 & 47.4 & 2.1 & 3.8 & $\cdots$ & 46.7 \\
\hline Postwar: & & & & & & \\
\hline lst 5 yrs. & 100.0 & 29.1 & 8.3 & 40.3 & -- & 22.3 \\
\hline 2nd 5 yrs. & 100.0 & 21.5 & 10.5 & 37.8 & $\cdots$ & 30.7 \\
\hline \multicolumn{7}{|l|}{ Worla War I: } \\
\hline Prewar . . & 100.0 & 35.5 & 23.7 & 3.2 & .7 & 36.9 \\
\hline Postwar: & & & & & & \\
\hline Ist $5 \mathrm{yrs}$ & 100.0 & 23.0 & 23.2 & 31.2 & .2 & 2.00 \\
\hline 2nd 5 yrs. & 100.0 & 21.6 & 21.3 & 21.3 & .2 & 32. \\
\hline \multicolumn{7}{|l|}{ World War II: } \\
\hline Prewar . & 100.0 & 12.9 & 12.2 & 3.1 & & \\
\hline Postwar: & & 30.5 & 19.2 & 10.2 & 14.2 & 26.0 \\
\hline lst 3 yrs. & 100.0 & & & & & \\
\hline
\end{tabular}

Source: M. Slade Kenärick, "A Century and a Half of Fedena Expenditures," Occasional Paver le Research, Inc.,

York: National, Table 3, p. 23. 


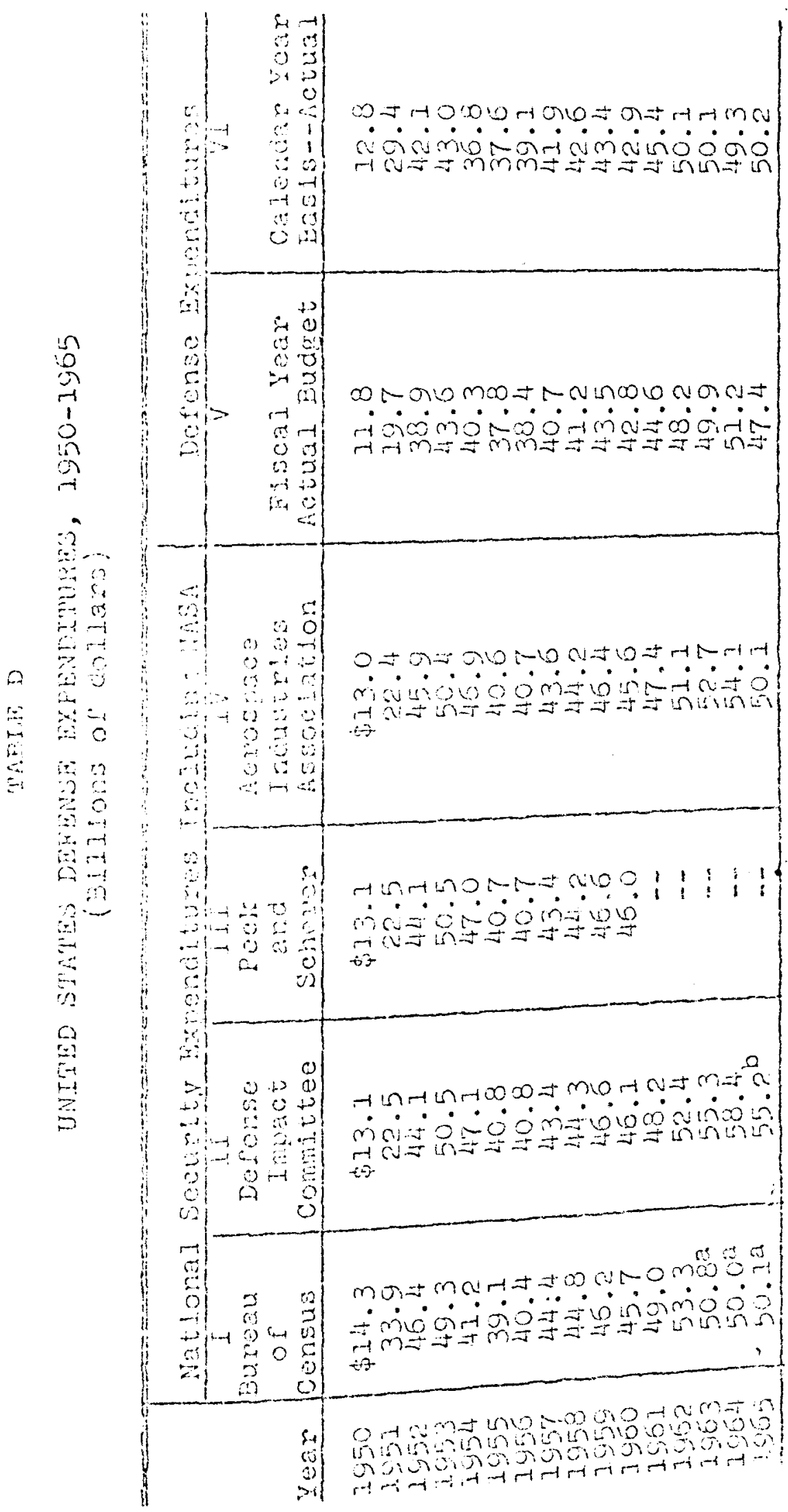




\begin{tabular}{|c|c|c|c|c|c|}
\hline & & & & 1951 & $1952^{\circ}$ \\
\hline \multicolumn{6}{|l|}{ Procurement: } \\
\hline Alroraft & $\cdot \cdot \cdot \cdot \cdot$ & $\cdot$ & - & $\$ 2,412$ & $\$ 4,8.88$ \\
\hline Misslies & . . . . . & ' & $\cdot$ & 21 & 169 \\
\hline $\operatorname{Sinps} \cdot$ & $\cdot \cdot \cdot \cdot \cdot$ & - & - & 382 & $62^{4}$ \\
\hline $\begin{array}{l}\text { Oranance, } \\
\text { related }\end{array}$ & $\begin{array}{l}\text { Ventcles \& } \\
\text { equipment }\end{array}$ & 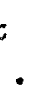 & • & 692 & 3,591 \\
\hline EIect:ical & \& Commo. & • & - & 193 & 597 \\
\hline other . & $\cdot \cdot \cdot \cdot \cdot$ & - & - & 276 & 1,609 \\
\hline $\operatorname{Tota} 1^{*}$ & . . . . & · & • & 3,976 & $.21,478$ \\
\hline $\begin{array}{l}\text { Research, De } \\
\text { Testin:s }\end{array}$ & $\begin{array}{l}\text { velopment, } \\
\text { Evaluation }\end{array}$ & & - & 758 & 1,164 \\
\hline
\end{tabular}

* Totals for 1954-68 do not add up dus Sources: Data for 1951 , 1952 , and 1 of the Committee on Approps Impact of Victram Soending: Inc., ferospace Facrs and F 
aU.S., Congress, joint Fconomic Combtied, Econonic Indicators: June, 1960, 9lst Corge., Ist sess., 1969, p. 2.

bstimate as of January, 1965.

Sources: Aerospace Inaustrues fesociation of America, Inc Aorosuace Factra a F.

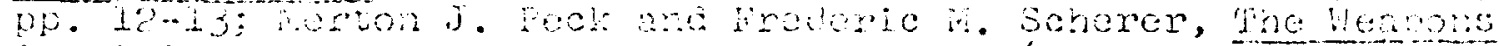

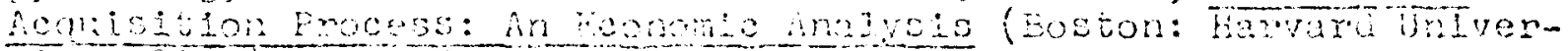

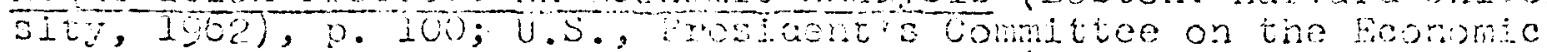

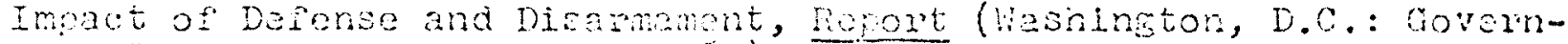

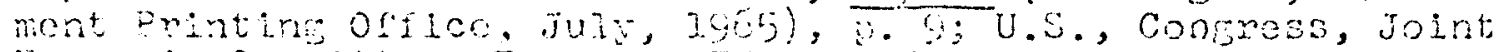
Econonic Comitites, Economin test of vietnem Snending, Houringe,

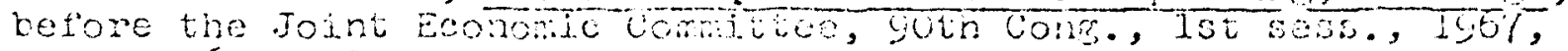
If, 2. 302; U.3., Deparment of Comwores, Lurcau of the consus.

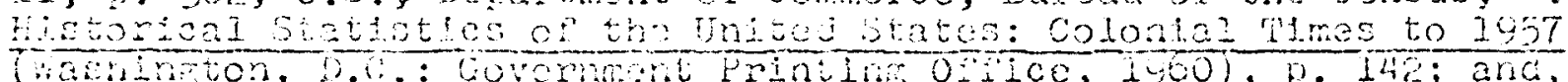

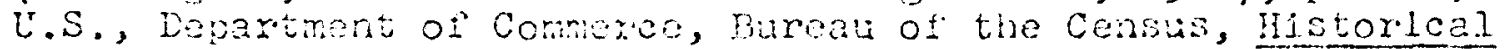
Statistics of the Unjted states: Colonial Tlmos to 197 : Contrua-

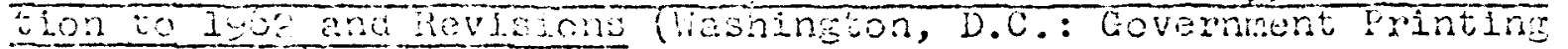

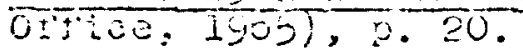




\section{APPENDIX II}

EMPLOYMENT, WAGES, AND INCOME

Table

A. Insured Employment in California, 1939-1964..

B. Insured Employment in the San Francisco Bay Area, 1939-1965 ............. 196

C. Insured Employment in the San Jose Metropoli$\tan$ Area, 1951-1965 . . . . . . . . 197

D. Wages Paid in Major Industrial Groups and Selected Subgroups in the San Francisco Bay Area during 1939, 1944, 1949, 1954, 1959, and 1964 .............. 198

E. Bay Area personal Income and Net Buying Power, 1950-1965...................... 199 


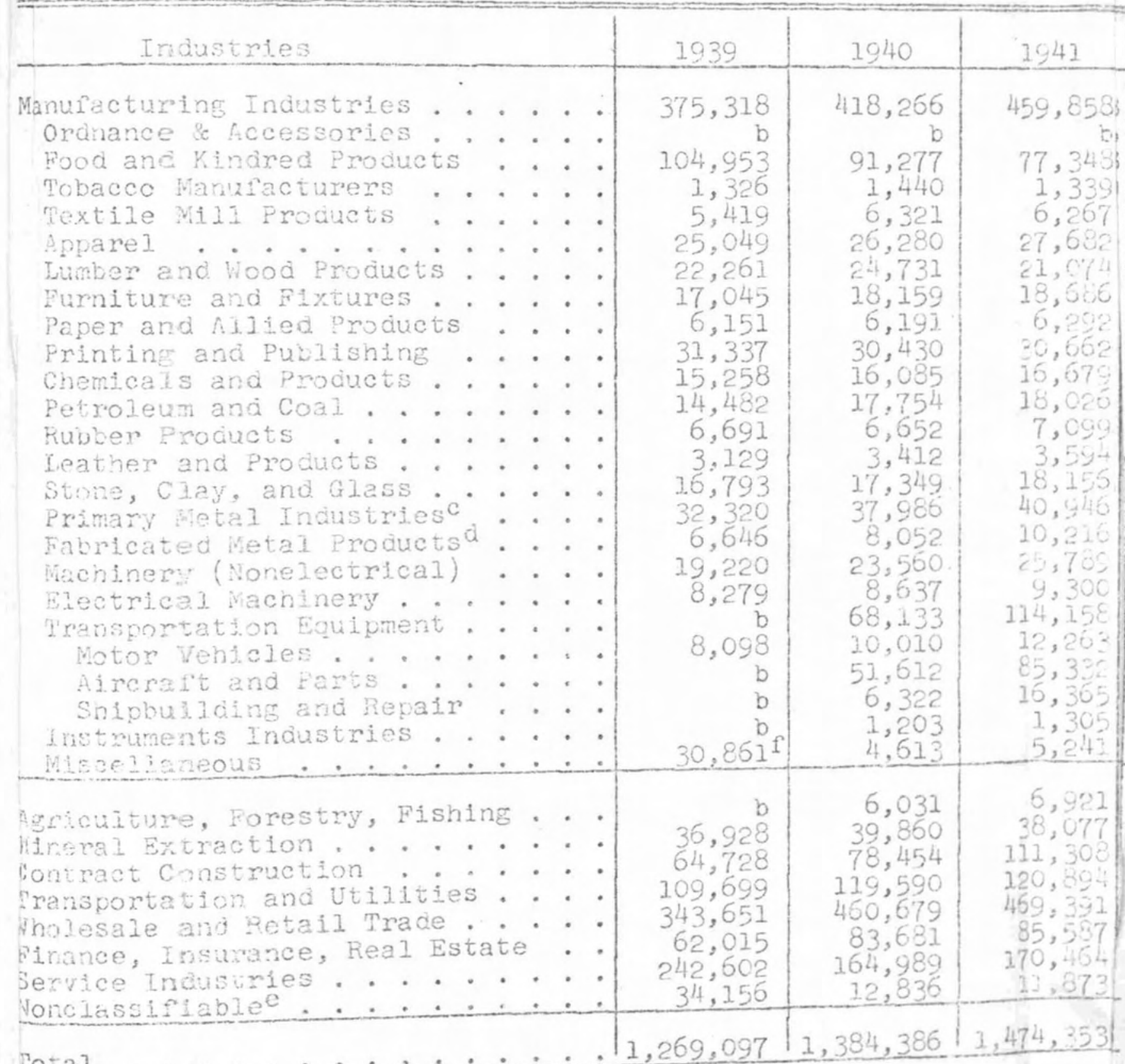

Total

aprior to 1946 , only employers ere covered by state unemoloyment insurance, therefore figures id ere covered by state unemoloynent insurange through 1945 . Hither

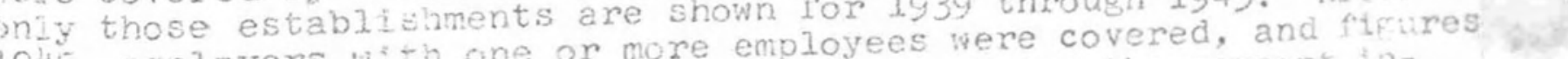
2945, employer or 1940 through the last column of this table, figures for 1y39 ata rease shown in be adjusted to more accurately coincide with

or the later years. Figures for 1939-1940 and 1942-1950 are innul averagos; for 1941 they are for the mo

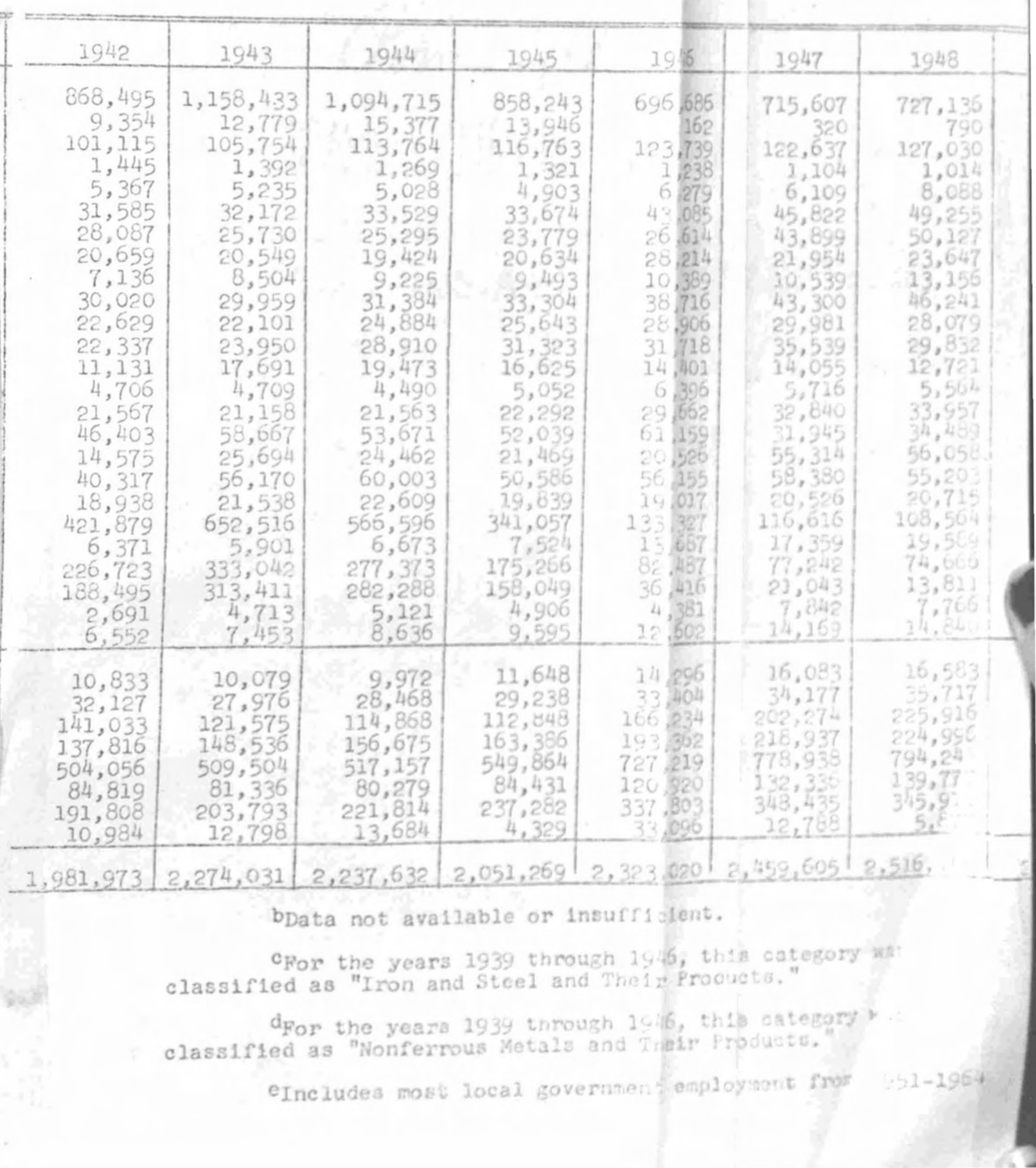


TABLE A

INSURED EMPLOYMENT IN CALIFORNIA, $1939-1964^{\mathrm{a}}$

\begin{tabular}{|c|c|c|c|c|c|c|c|c|c|c|c|c|c|c|c|c|}
\hline 1949 & 1950 & 2951 & 1952 & 1953 & 1954 & 1955 & 1955 & 1957 & $1958^{\circ}$ & 1959 & 1960 & 1961 & 1962 & 1963 & 1964 & $\begin{array}{l}\text { P. Increase for Adjustment } \\
\text { in Figures for } 1938-45\end{array}$ \\
\hline $\begin{array}{r}694,335 \\
371 \\
124,435 \\
991 \\
7,171 \\
48,216 \\
45,404 \\
22,444 \\
12,844 \\
46,943 \\
28,691 \\
30,795 \\
12,236 \\
5,293 \\
31,948 \\
33,991 \\
46,409 \\
47,606 \\
20,974 \\
107,348 \\
20,031 \\
79,471 \\
7,236 \\
5,781 \\
13,904 \\
\end{array}$ & $\begin{array}{r}758,448 \\
668 \\
132,312 \\
848 \\
8,049 \\
50,809 \\
52,758 \\
24,758 \\
13,907 \\
47,787 \\
29,646 \\
32,221 \\
13,472 \\
5,363 \\
33,933 \\
39,104 \\
54,943 \\
49,659 \\
25,086 \\
118,467 \\
23,607 \\
88,432 \\
5,956 \\
8,045 \\
15,303 \\
\end{array}$ & $\begin{array}{r}904,524 \\
2,685 \\
143,673 \\
4,45 \\
7,276 \\
48,049 \\
64,635 \\
23,487 \\
15,888 \\
48,7118 \\
38,875 \\
34,455 \\
14,448 \\
5,439 \\
37,364 \\
48,461 \\
61,294 \\
69,219 \\
42,392 \\
175,3325 \\
22,787 \\
144,132 \\
8,984 \\
10,792 \\
15,704 \\
\end{array}$ & 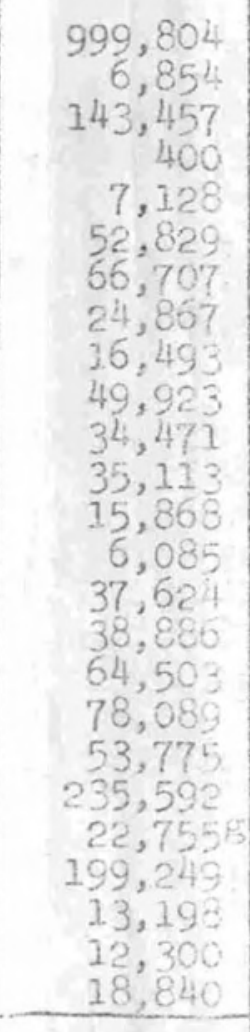 & $\begin{array}{r}1,077,114 \\
13,315 \\
147,958 \\
342 \\
7,335 \\
54,112 \\
65,847 \\
25,409 \\
18,049 \\
52,342 \\
35,314 \\
34,519 \\
17,049 \\
6,363 \\
38,543 \\
49 \\
74,048 \\
78,465 \\
67,061 \\
67,131 \\
257,161 \\
3,477 \\
210,998 \\
14,193 \\
13,715 \\
21,036 \\
\end{array}$ & $\begin{array}{r}1,045,130 \\
12,061 \\
146,260 \\
623 \\
6,617 \\
52,284 \\
55,6635 \\
23,814 \\
19,341 \\
54,034 \\
35,986 \\
35,016 \\
15,653 \\
5,776 \\
36,176 \\
41,094 \\
72,228 \\
74,557 \\
62,295 \\
261,578 \\
25,472 \\
224,717 \\
12,495 \\
14,418 \\
19,883 \\
\end{array}$ & $\begin{array}{r}1,122,661 \\
17,158 \\
137,998 \\
267 \\
6,776 \\
55,490 \\
69,295 \\
28,206 \\
21,627 \\
56,274 \\
37,134 \\
35,710 \\
17,715 \\
6,165 \\
38,238 \\
45,368 \\
78,514 \\
80,753 \\
73,297 \\
279,951 \\
36,089 \\
232,648 \\
10,586 \\
15,202 \\
21,743\end{array}$ & $\begin{array}{r}1,211,105 \\
25,654 \\
152,6773 \\
46 \\
6,095 \\
56,186 \\
68,050 \\
21,178 \\
23,960 \\
60,744 \\
39,889 \\
35,331 \\
17,726 \\
6,700 \\
41,055 \\
43,483 \\
80,619 \\
91,275 \\
87,419 \\
305,515 \\
31,084 \\
26,329 \\
10,478 \\
15,314 \\
23,221 \\
\end{array}$ & $\begin{array}{r}1,280,094 \\
28,304 \\
148,668 \\
50 \\
5,229 \\
56,091 \\
51,119 \\
30,457 \\
25,058 \\
64,081 \\
41,078 \\
35,330 \\
18,615 \\
6,551 \\
40,206 \\
50,104 \\
88,024 \\
97,198 \\
106,918 \\
330,850 \\
33,807 \\
285,605 \\
11,623 \\
18,916 \\
25,357 \\
\end{array}$ & 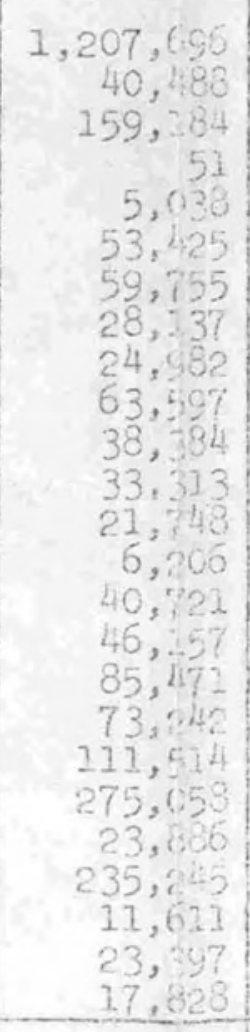 & $\begin{array}{r}1,347,371 \\
55,583 \\
172,113 \\
49 \\
5,767 \\
57,552 \\
64,324 \\
32,115 \\
27,115 \\
67,995 \\
40,363 \\
33,267 \\
25,994 \\
5,881 \\
43,871 \\
54,338 \\
94,953 \\
84,770 \\
45,688 \\
293,014 \\
29,934 \\
24,841 \\
22,110 \\
22,737 \\
29,832 \\
\end{array}$ & $\begin{array}{r}1,317,336 \\
55,747 \\
173,025 \\
45 \\
5,979 \\
58,163 \\
51,120 \\
30,087 \\
27,566 \\
70,810 \\
41,779 \\
30,982 \\
25,222 \\
5,348 \\
44,441 \\
50,602 \\
93,845 \\
83,087 \\
166,068 \\
251,293 \\
28,719 \\
205,689 \\
12,831 \\
22,576 \\
19,651 \\
\end{array}$ & $\begin{array}{r}1,325,523 \\
72,656 \\
167,773 \\
37 \\
6,144 \\
58,045 \\
57,629 \\
29,602 \\
28,195 \\
72,015 \\
42,886 \\
30,031 \\
25,097 \\
5,629 \\
43,969 \\
52,628 \\
93,740 \\
83,898 \\
190,364 \\
232,208 \\
28,325 \\
188,838 \\
10,9528 \\
23,288 \\
19,689 \\
\end{array}$ & $\begin{array}{r}1,397,626 \\
105,328 \\
165,988 \\
5,57 \\
6,500 \\
59,517 \\
55,237 \\
30,996 \\
29,703 \\
73,229 \\
44,533 \\
29,377 \\
27,356 \\
5,807 \\
45,558 \\
52,308 \\
95,827 \\
90,122 \\
213,323 \\
220,244 \\
30,963 \\
172,305 \\
11,602 \\
23,964 \\
22,652 \\
\end{array}$ & $\begin{array}{r}1,406,936 \\
103,287 \\
164,914 \\
5,54 \\
6,969 \\
61,802 \\
54,749 \\
32,154 \\
30,418 \\
74,552 \\
45,115 \\
30,752 \\
27,305 \\
5,555 \\
49,559 \\
52,537 \\
96,480 \\
91,936 \\
210,559 \\
218,567 \\
32,220 \\
159,613 \\
10,439 \\
25,557 \\
23,605 \\
\end{array}$ & $\begin{array}{r}1,399,373 \\
96,301 \\
269,073 \\
56 \\
7,098 \\
63,611 \\
56,089 \\
32,530 \\
30,146 \\
7,4443 \\
74,562 \\
31,333 \\
25,376 \\
5,636 \\
50,975 \\
52,906 \\
98,532 \\
96,352 \\
790,504 \\
214,469\end{array}$ & $\begin{array}{r}4.7 \\
.4 \\
3.4 \\
1.9 \\
2.9 \\
6.2 \\
5.7 \\
8.9 \\
3.1 \\
.8 \\
4.2 \\
1.8 \\
2.5 \\
12.0 \\
9.7 \\
4.9 \\
8.8 \\
7.1 \\
1.7 \\
\mathrm{~b} \\
2.9 \\
3 . \\
\mathrm{b} \\
13.5 \\
\end{array}$ \\
\hline $\begin{array}{r}15,803 \\
34,506 \\
197,547 \\
219,094 \\
770,818 \\
1140,928 \\
340,884 \\
3,561 \\
\end{array}$ & $\begin{array}{r}17,080 \\
32,253 \\
206,500 \\
214,000 \\
780,868 \\
151,167 \\
340,377 \\
4,292 \\
\end{array}$ & $\begin{array}{r}19,888 \\
35,458 \\
247,587 \\
232,393 \\
819,337 \\
159,772 \\
363,057 \\
3,593 \\
\end{array}$ & $\begin{array}{r}20,993 \\
36,244 \\
251,778 \\
240,476 \\
858,329 \\
165,444 \\
385,586 \\
2,728 \\
\end{array}$ & $\begin{array}{r}20,530 \\
38,731 \\
252,274 \\
252,233 \\
889,840 \\
173,348 \\
404,893 \\
2,598 \\
\end{array}$ & $\begin{array}{r}19,007 \\
36,381 \\
255,677 \\
248,361 \\
882,282 \\
173,870 \\
410,234 \\
2,730 \\
\end{array}$ & $\begin{array}{r}20,076 \\
38,445 \\
282,796 \\
258,936 \\
931,588 \\
200,345 \\
441,486 \\
2,932 \\
\end{array}$ & $\begin{array}{r}19,579 \\
37,834 \\
311,256 \\
280,490 \\
980,151 \\
197,208 \\
472,545 \\
2,515 \\
\end{array}$ & $\begin{array}{r}18,766 \\
36,7753 \\
282,870 \\
296,665 \\
1,026,017 \\
206,142 \\
501,289 \\
3,736 \\
\end{array}$ & $\begin{array}{r}22,505 \\
33,725 \\
297,030 \\
291,564 \\
980,247 \\
211,281 \\
483,72 \\
8,295 \\
\end{array}$ & $\begin{array}{r}23,540 \\
33,706 \\
324,515 \\
295,499 \\
1,045,450 \\
222,164 \\
536,131 \\
11,846 \\
\end{array}$ & $\begin{array}{r}24,075 \\
31,333 \\
305,024 \\
304,058 \\
1,073,600 \\
239,114 \\
561,, 856 \\
11,92 \\
\end{array}$ & $\begin{array}{r}26,179 \\
30,924 \\
306,558 \\
300,845 \\
1,090,710 \\
247,842 \\
601,988 \\
14,297 \\
\end{array}$ & $\begin{array}{r}26,179 \\
30,994 \\
323,497 \\
309,062 \\
1,136,196 \\
264,279 \\
635,340 \\
15,291 \\
\end{array}$ & $\begin{array}{r}298,483 \\
30,332 \\
346,460 \\
317,912 \\
1,177,151 \\
280,520 \\
670,909 \\
16,710 \\
\end{array}$ & $\begin{array}{r}299,122 \mathrm{~h} \\
31,303 \\
355,794 \\
327,655 \\
239,250 \\
296,555\end{array}$ & $\begin{array}{r}21.0 \\
5.9 \\
20.9 \\
5.8 \\
18.8 \\
27.4 \\
23.3 \\
0 \\
\end{array}$ \\
\hline 438,576 & $2,524,995$ & $2,785,618$ & $2,962,386$ & $3,111,361$ & $3,078,672$ & $3,299,275$ & $3,512,583$ & $3,642,332$ & $3,536,435$ & $3,841,222$ & $3,869,287$ & $3,544,866$ & $4,132,044$ & $4,274,065$ & $4,409,264$ & 24.1 \\
\hline
\end{tabular}

Parts" and "Shivbuild probably ancludes data for HAipratt and

Source: Californta, Department of Empleyntent, Research and

BDecreased employnent caused by trade dispute.

hinciuces employment subject to the provisions of the
Disability Insurance piogram for agricultural workers.

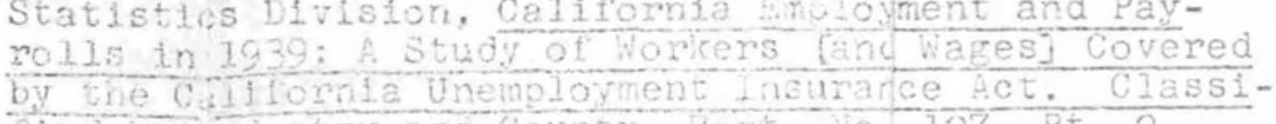




\begin{tabular}{|c|c|c|c|c|c|}
\hline Indus & & 39 & 40 & 10 & 1942 \\
\hline 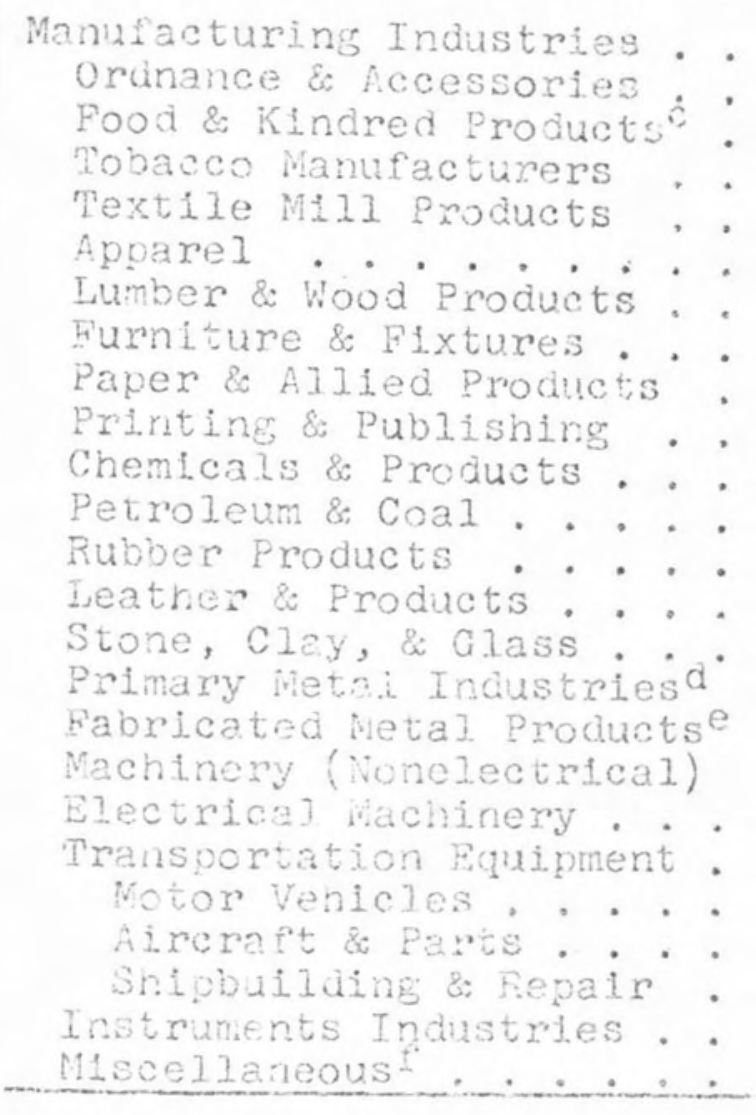 & 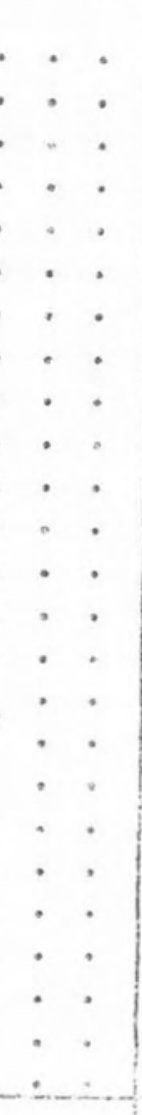 & $\begin{array}{r}122,411 \\
b \\
38,032 \\
b \\
1,835 \\
6,205 \\
1,214 \\
4,181 \\
1,925 \\
12,753 \\
6,986 \\
6,511 \\
475 \\
1,113 \\
4,910 \\
15,449 \\
1,449 \\
5,181 \\
2,984 \\
b \\
2,193 \\
b \\
b \\
b \\
9,015 \\
\end{array}$ & $\begin{array}{r}123, \\
30, \\
3, \\
6, \\
1, \\
4, \\
1, \\
12, \\
7, \\
7, \\
1, \\
4, \\
16, \\
2, \\
7, \\
3, \\
7, \\
2,\end{array}$ & $\begin{array}{r}126,677 \\
b \\
22,575 \\
725 \\
3,092 \\
6,234 \\
1,284 \\
4,224 \\
1,855 \\
12,309 \\
7,987 \\
7,752 \\
402 \\
1,070 \\
4,591 \\
17,309 \\
1,815 \\
8,072 \\
3,638 \\
12,723 \\
3,419 \\
b \\
3611 \\
0 \\
23,342\end{array}$ & $\begin{array}{r}256,347 \\
1,418 \\
35,480 \\
892 \\
1,459 \\
6,958 \\
1,018 \\
5,100 \\
2,094 \\
11,883 \\
9,341 \\
10,736 \\
430 \\
1,128 \\
5,740 \\
18,931 \\
2,386 \\
11,866 \\
4,130 \\
106,077 \\
1,988 \\
163 \\
82,292 \\
b \\
9,020 \\
\end{array}$ \\
\hline 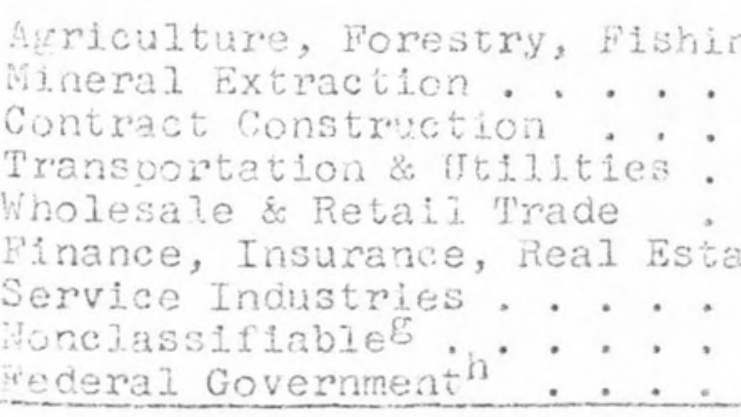 & 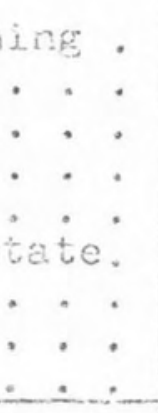 & $\begin{array}{r}35,361 \\
95,816 \\
24,382 \\
62,637 \\
19,989 \\
\mathrm{~b} \\
\end{array}$ & $\begin{array}{r}21,576 \\
112,152 \\
127,822 \\
31,860 \\
41,100 \\
11,723 \\
\end{array}$ & $\begin{array}{r}558 \\
1,130 \\
24,051 \\
42,350 \\
129,176 \\
32,475 \\
41,540 \\
13,355 \\
\end{array}$ & $\begin{array}{r}1 \\
39 \\
51 \\
139 \\
32 \\
45 \\
26\end{array}$ \\
\hline & & & & & \\
\hline
\end{tabular}

aprlor to 1946, only emoloyers with four or more employees were covercd by state unemoloyment insurange, therefore flgures for only those establishments are shown for 1933 through 1945 . Aften 1945, employers with one or more employees were covered, and figures for 1946 through 2965 replect this change. Using the percent increase shown th the last column of Table A, this Appendix, igures for 1939 throfig 1945 can be adjusted to more accurately colnetde with data for later years. Figures for $1939-1940$ and $1942-1950$ are annual averages; for 1941 thèy are for January; for $1951-1958$ and $1960-1965$ they are for Ju2y; and for 1959 they are for June. 


\begin{tabular}{|c|c|c|c|c|c|c|c|c|c|c|c|c|c|c|c|c|c|c|c|c|}
\hline 1945 & $1946^{\circ}$ & 1947 & 1948 & 1949 & 950 & 19 & 1952 & 1953 & 1954 & 1955 & 1956 & 1957 & 1958 & 1959 & 2960 & 1961 & 1962 & 1963 & 1964 & $1965^{k}$ \\
\hline $\begin{array}{r}48,243 \\
1,719 \\
40,514 \\
723 \\
1,258 \\
6,565 \\
884 \\
5,205 \\
2,642 \\
11,861 \\
9,881 \\
14,234 \\
657 \\
917 \\
6,052 \\
18,140 \\
2,784 \\
13,444 \\
4,855 \\
86,009 \\
1,763 \\
61,659 \\
61,183 \\
b \\
19,899 \\
\end{array}$ & $\begin{array}{r}185,267 \\
b \\
42,287 \\
741 \\
1,530 \\
8,257 \\
1,969 \\
5,375 \\
3,532 \\
13,547 \\
11,964 \\
13,574 \\
987 \\
1,424 \\
6,481 \\
21,020 \\
3,878 \\
15,417 \\
3,714 \\
23,471 \\
4,943 \\
17,620 \\
b \\
4,105 \\
\end{array}$ & $\begin{array}{r}176,729 \\
b \\
42,833 \\
699 \\
1,510 \\
8,691 \\
3,804 \\
5,899 \\
3,553 \\
15,224 \\
12,689 \\
13,790 \\
987 \\
1,354 \\
7,138 \\
11,511 \\
16,852 \\
18,248 \\
4,359 \\
22,182 \\
5,203 \\
0 \\
15,804 \\
1,132 \\
4,439 \\
\end{array}$ & $\begin{array}{r}178,452 \\
b \\
43,599 \\
650 \\
3,040 \\
9,080 \\
4,094 \\
6,078 \\
4,277 \\
15,796 \\
11,231 \\
12,934 \\
814 \\
1,254 \\
6,655 \\
12,424 \\
17,010 \\
15,922 \\
6,209 \\
15,202 \\
b \\
b \\
9,598 \\
1,060 \\
3,547 \\
\end{array}$ & $\begin{array}{r}175,591 \\
41 \\
41,722 \\
647 \\
2,158 \\
8,465 \\
3,536 \\
5,416 \\
4,122 \\
25,383 \\
11,187 \\
12,342 \\
1,803 \\
6,101 \\
12,184 \\
15,080 \\
13,211 \\
6,272 \\
11,018 \\
6,385 \\
6 \\
4,421 \\
810 \\
3,731 \\
\end{array}$ & $\begin{array}{r}186,923 \\
b \\
46,046 \\
520 \\
2,500 \\
8,689 \\
3,819 \\
5,513 \\
4,488 \\
16,681 \\
11,481 \\
12,792 \\
953 \\
1,056 \\
7,, 105 \\
12,867 \\
17,159 \\
13,707 \\
6,565 \\
10,693 \\
7,299 \\
0 \\
3,224 \\
3,45 \\
3,285 \\
\end{array}$ & 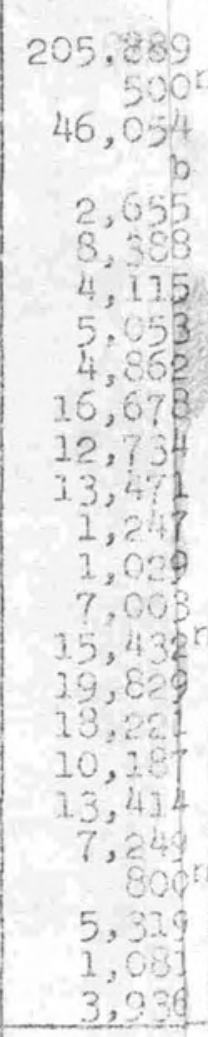 & $\begin{array}{r}208,933 \\
1,187 \\
52,261 \\
b \\
2,216 \\
8,792 \\
3,726 \\
5,132 \\
5,009 \\
16,937 \\
12,199 \\
13,223 \\
1,313 \\
1,148 \\
7,924 \\
8,575 \\
18,853 \\
17,742 \\
11,951 \\
15,021 \\
5,714 \\
1,754 \\
7,390 \\
1,153 \\
4,571 \\
\end{array}$ & $\begin{array}{r}227,542 \\
1,775 \\
54,065 \\
b \\
1,988 \\
9,241 \\
3,528 \\
4,667 \\
6,254 \\
17,526 \\
12,715 \\
12,735 \\
1,619 \\
1,299 \\
8,315 \\
13,952 \\
20,465 \\
18,120 \\
13,776 \\
19,876 \\
8,967 \\
3,070 \\
7,647 \\
1,192 \\
4,434 \\
\end{array}$ & \begin{tabular}{|r|r|}
220,942 \\
$1,264 n$ \\
53,952 \\
$\mathrm{~b}$ \\
2,083 \\
9,104 \\
3,2270 \\
4,231 \\
6,537 \\
17,814 \\
12,533 \\
13,120 \\
1,326 \\
1,218 \\
8,379 \\
$11,920 n$ \\
20,567 \\
18,157 \\
12,609 \\
17,185 \\
7,658 \\
3,340 \\
5,945 \\
$1,192 n$ \\
4,524 \\
\end{tabular} & $\begin{array}{r}220,195 \\
1,804 \\
47,045 \\
b \\
2,054 \\
9,546 \\
3,831 \\
4,572 \\
7,346 \\
18,518 \\
12,795 \\
13,215 \\
1,427 \\
996 \\
8,706 \\
12,208 n \\
21,500 \\
18,204 \\
13 \\
16,310 \\
1,914 \\
2,934 \\
6,198 \\
1,146 \\
1,466 \\
5,189 \\
\end{array}$ & $\begin{array}{c}235,047 \\
2,300 \mathrm{n} \\
54,808 \\
\mathrm{~b} \\
1,657 \\
9,223 \\
3,581 \\
4,851 \\
8,368 \\
19,539 \\
13,023 \\
12,851 \\
1,454 \\
1,012 \\
9,182 \\
8,961 \mathrm{nc} \\
22,355 \\
20,734 \\
17,931 \\
15,525 \\
4,671 \\
2,680 \\
5,421 \\
1,701^{\mathrm{n}} \\
5,991 \\
\end{array}$ & $\begin{array}{r}249,113 \\
4,409 \\
55,448 \\
\text { b } \\
1,807 \\
9,320 \\
3,119 \\
4,769 \\
8,886 \\
20,161 \\
13,628 \\
12,755 \\
1,431 \\
979 \\
9,318 \\
12,587 \\
23,189 \\
22,047 \\
22,898 \\
17,204 \\
7,497 \\
3,303 \\
6,142 \\
2,067 \\
3,091 \\
\end{array}$ & $\begin{array}{r}243,005 \\
9,442 . \\
52,585 \\
1,0 \\
1,051 \\
8,642 \\
3,150 \\
4,616 \\
9,258 \\
20,263 \\
13,006 \\
12,050 \\
1,823 \\
998 \\
9,540 \\
12,951 \\
22,100 \\
15,721 \\
22,968 \\
16,325 \\
7,575 \\
2,285 \\
6,037 \\
2,062 \\
3,454 \\
\end{array}$ & $\begin{array}{r}257,061 \\
13,000 \\
48,714 \\
1,04 \\
1,040 \\
8,450 \\
3,402 \\
5,762 \\
9,691 \\
20,555 \\
12,988 \\
11,961 \\
2,075 \\
873 \\
9,339 \\
14,495 \\
23,959 \\
19,894 \\
28,208 \\
17,296 \\
6,678 \\
3,169 \\
5,399 \\
2,351 \\
3,638 \\
\end{array}$ & $\begin{array}{r}277,592 \\
18,6250 \\
60,827 \\
6 \\
659 \\
8,801 \\
2,779 \\
5,489 \\
9,762 \\
21,982 \\
13,328 \\
10,485 \\
1,700 \\
10,765 \\
13,443 \\
24,729 \\
19,781 \\
20,919 \\
15,886 \\
8,430 \\
2,549 \\
5,054 \\
2,553 \\
3,350 \\
\end{array}$ & $\begin{array}{r}277,693 \\
23,032 \\
56,297 \\
6 \\
890 \\
8,721 \\
2,858 \\
4,945 \\
10,129 \\
22,307 \\
12,542 \\
10,435 \\
2,237 \\
756 \\
10,698 \\
13,355 \\
23,565 \\
19,667 \\
33,523 \\
15,855 \\
8,603 \\
2,470 \\
4,457 \\
2,574 \\
3,206 \\
\end{array}$ & $\begin{array}{r}290,118 \\
25,443 \\
55,344 \\
v \\
845 \\
8,771 \\
2,955 \\
5,275 \\
10,385 \\
22,537 \\
12,814 \\
10,365 \\
2,266 \\
10,7688 \\
12,7404 \\
22,8150 \\
21,118 \\
38,894 \\
18,459 \\
9,640 \\
2,500\end{array}$ & $\begin{array}{r}290,013 \\
25,446 p \\
55,984 \\
b \\
839 \\
8,842 \\
2,819 \\
5,127 \\
10,381 \\
22,653 \\
12,599 \\
11,637 \\
2,242 \\
688\end{array}$ & $\begin{array}{r}291,027 \\
24,300 \\
55,986 \\
6 \\
686 \\
9,079 \\
2,696 \\
5,267 \\
10,309 \\
23,398 \\
13,190 \\
11,682 \\
2,258 \\
11,279 \\
13,272 \\
23,532 \\
22,211 \\
37,420 \\
17,781 \\
11,489 \\
2,365 \\
3,370\end{array}$ & $\begin{array}{r}288,900 \\
27,400 \mathrm{q} \\
53,800 \\
\mathrm{~b} \\
800 \\
8,900 \\
2,600 \\
4,400 \\
13,700 \\
20,200 \\
13,000 \\
10,000 \\
1,500 \\
500 \\
11,200 \\
12,900 \\
23,500 \\
23,500 \\
40,300 \\
14,100 \\
9,600 \\
1,900 \\
2,500 \\
3,300 \\
3,300 \\
\end{array}$ \\
\hline $\begin{array}{r}977 \\
1,199 \\
33,080 \\
62,761 \\
153,825 \\
31,331 \\
56,722 \\
15,039 \\
\end{array}$ & $\begin{array}{r}2,752 \\
1,571 \\
48,702 \\
69,651 \\
200,796 \\
43,742 \\
83,414 \\
6,847\end{array}$ & $\begin{array}{r}1,859 \\
2,774 \\
56,895 \\
82,719 \\
212,378 \\
48,761 \\
86,234 \\
2,836 \\
\quad 0 \\
\end{array}$ & $\begin{array}{r}1,864 \\
1,928 \\
61,590 \\
82,937 \\
214,891 \\
51,952 \\
86,686 \\
1,035 \\
0 \\
\end{array}$ & $\begin{array}{r}1,810 \\
1,967 \\
56,312 \\
80,793 \\
207,455 \\
51,825 \\
84,901 \\
638 \\
\\
\end{array}$ & $\begin{array}{r}1,739 \\
1,548 \\
64,416 \\
79,126 \\
205,258 \\
55,319 \\
83,241 \\
744 \\
6 \\
\end{array}$ & $\begin{array}{r}1,816 \\
1,555 \\
72,337 \\
82,872 \\
211,15 \\
58,000 \\
91,529\end{array}$ & $\begin{array}{r}1,817 \\
1,500 \\
73,026 \\
83,203 \\
217,880 \\
59,147 \\
92,555 \\
902\end{array}$ & $\begin{array}{r}1,797 \\
1,578 \\
63,078 \\
87,117 \\
202,381 \\
59,991 \\
93,687 \\
485 \\
6 \\
\end{array}$ & $\begin{array}{r}1,793 \\
1,350 \\
60,753 \\
83,410 \\
217,960 \\
59,888 \\
94,139 \\
472\end{array}$ & $\begin{array}{r}2,064 \\
1,699 \\
73,549 \\
87,893 \\
236,425 \\
66,891 \\
97,774 \\
528 \\
6\end{array}$ & $\begin{array}{r}2,399 \\
1,877 \\
78,549 \\
93,969 \\
238,784 \\
53,989 \\
103,595 \\
508 \\
0 \\
\end{array}$ & $\begin{array}{r}2,217 \\
1,877 \\
77,077 \\
100,859 \\
246,180 \\
66,008 \\
108,410 \\
606 \\
86,506 \\
\end{array}$ & $\begin{array}{r}2,893 \\
2,037 \\
76,699 \\
96,432 \\
233,388 \\
65,860 \\
11.7,588 \\
53,09 \\
83,361 \\
\end{array}$ & $\begin{array}{r}3,764 \\
2,155 \\
80,933 \\
97,189 \\
242,708 \\
67,499 \\
133,370 \\
850 \\
84,116 \\
\end{array}$ & $\begin{array}{r}2,912 \\
2,064 \\
78,725 \\
99,781 \\
250,790 \\
73,655 \\
242,653 \\
700 \\
84,295\end{array}$ & $\begin{array}{r}2,897 \\
2,039 \\
77,847 \\
97,970 \\
255,119 \\
75,468 \\
142,653 \\
804 \\
86,596 \\
\end{array}$ & $\begin{array}{r}8 \\
100 \\
260\end{array}$ & 9 & $\begin{array}{r}3,700 \\
2,381 \\
90,832 \\
103,8835 \\
283,945 \\
86,200 \\
173,337 \\
85,769 \\
85\end{array}$ & $\begin{array}{r}b \\
2,, 100 \\
78,400 \\
120,900 \\
289,800 \\
90,300 \\
219,200 \\
b \\
76,500 \\
\end{array}$ \\
\hline & & & & & & & & & & & & & & & & & & & & \\
\hline
\end{tabular}

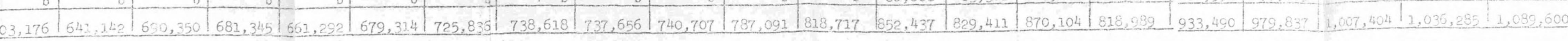

Data najiable or insufficient.

Seasonal ructuations not indicated.

For the years 1939 through 1946, this category was classi. "Iron and Steel and Their Products."

or the years 1939 through 1945 , this category was classionferrous hetals and Mncir Products some years after 1950 this category may include figures for ordnance which are estmated in the ordegry.

FFor the years 1939 through 1944, this category includes the includes the total for Solano County.

hFederai installations and Federal civilian employment; the figure for Bay Area does not include Federa? governent, employment. i. Data urcbably not accurate.

Jner des shipouilaing in San Neteo County.

kDate for 1065 may not be very rellable, as

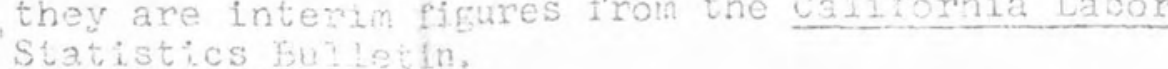

Iprobast trowades beme shipbuizaine 
MIncIudes all manufacturing for Marin County, a large amount of which was in the shipbuilding industry at Marin Shipyard. ceeding years.

nEstimated from data for other months and previous and suc-

OFigures low due to trade dispute.

PData for the month of July.

Includes a small number of other durable industries for the San Jose SMSA.

Sources: Calculated from, California, Department of Employment, Research and Statistics Divisjon, California Employment and Payrolls in 1939: A Study of Workers [and wages] Covered by the California Unemployment Insurance Act. Classified by Industry and County, Fept. 10. 127, एt. 2 (August, 1941), and Pts. 3-13 and $14 \mathrm{c}-27 \mathrm{c}$ for the years 1940-1964; Californ1a, Department of Industrial Relations, Division of Lavor Statistics and Law Enforcement, California Labor Statistics Bulletin: Metropojitan Areas (Sacramento, July, 1965), pp. 9-10; Californla, Denartment of Finance, California Statistical Abstmact, 1958 (Sacramento, 1958), p. 20; California, Department of Employment, Division of Research and Statist1es, Employment and Payrolls: San FranciscoQekland Labor Warket Area, 1958-1904, Rept. No. 127e, No. I (Sacxamento, 1967), pp. 1-52; and Calffornia, Department of Employment, Research and Statistics Section, Estimated Employment, Unemoloyment and Iabor Foree: San Jose Metropolitan Area, 1949-1968. Series of March, 1968 (Sacramento, January, 1969), unpaginated. 
TABLE C

INSURED EMPLOYMENT IN THE SAN JOSE METROPOLITAN AREA, P951-1965

\begin{tabular}{|c|c|c|c|c|c|c|c|c|c|c|c|c|c|c|c|}
\hline Ind & 951 & 1252 & .2953 & 1954 & 1955 & 1956 & 1957 & & a & 960 & 3961 & 62 & 1963 & 1964 & 1965. \\
\hline 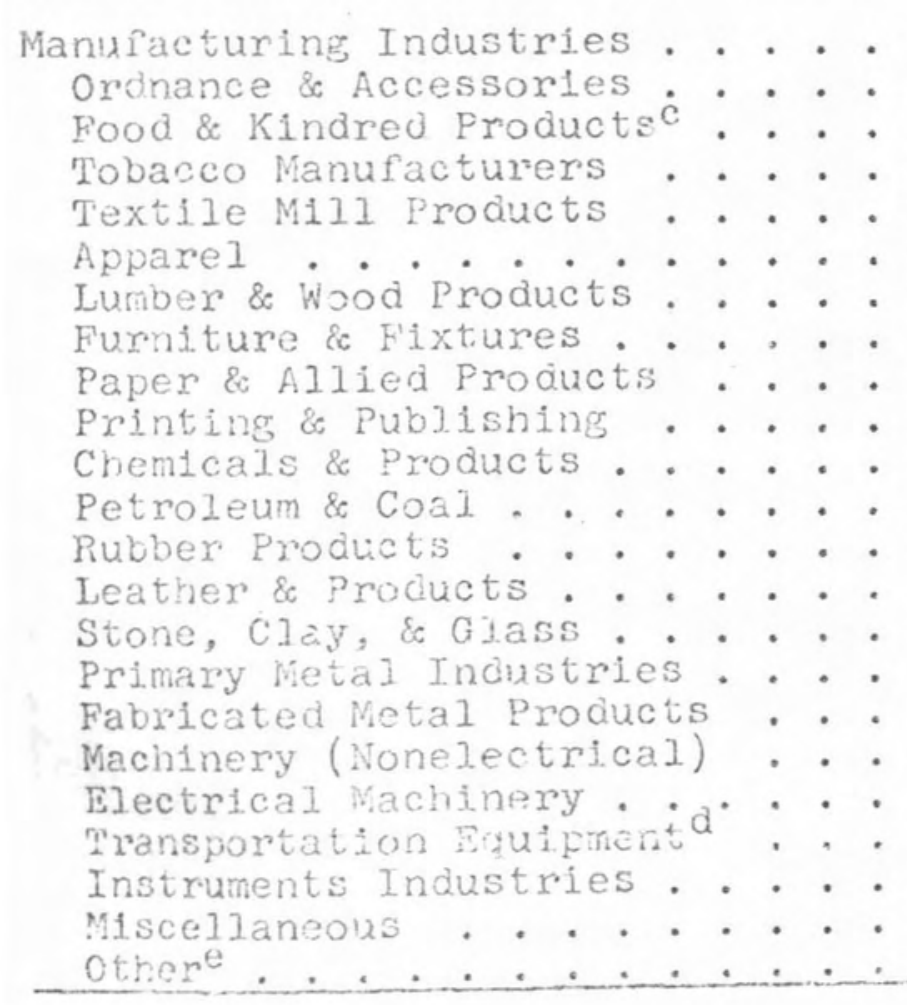 & $\begin{array}{r}28,372 \\
\mathrm{~b} \\
14,307 \\
\mathrm{~b} \\
\mathrm{~b} \\
\mathrm{~b} \\
1,150 \\
\mathrm{~b} \\
\mathrm{~b} \\
1,187 \\
671 \\
\mathrm{~b} \\
\mathrm{~b} \\
\mathrm{~b} \\
1,531 \\
2003 \\
1,620 \\
2,458 \\
4,079 \\
\mathrm{~b} \\
\mathrm{~b} \\
1,369 \\
\mathrm{~b}\end{array}$ & $\begin{array}{r}30,076 \\
b \\
14,605 \\
b \\
b \\
b \\
1,047 \\
b \\
b \\
1,250 \\
628 \\
b \\
b \\
b \\
1,506 \\
297 \\
1,441 \\
2,866 \\
4,429 \\
b \\
b \\
2,007 \\
b\end{array}$ & $\begin{array}{r}31,602 \\
b \\
15,439 \\
b \\
b \\
340 \\
1,036 \\
b \\
319 \\
1,317 \\
676 \\
b \\
b \\
b \\
1,484 \\
227 \\
1,509 \\
2,614 \\
5,031 \\
b \\
b \\
303 \\
1,331\end{array}$ & $\begin{array}{r}32,494 \\
800 \mathrm{~g} \\
16,188 \\
\mathrm{~b} \\
\mathrm{~b} \\
335 \\
95 \mathrm{i} h \\
\mathrm{~b} \\
372 \\
1,354 \\
725 \\
\mathrm{~b} \\
\mathrm{~b} \\
\mathrm{~b} \\
1,728 \\
200 \mathrm{~g} \\
1,516 \\
2,551 \\
4,847 \\
\mathrm{~b} \\
50 \mathrm{~s} \\
317\end{array}$ & $\begin{array}{r}34,460 \\
1,300 \\
12,921 \\
\mathrm{~b} \\
\mathrm{~b} \\
361 \\
1,218 \\
\mathrm{~b} \\
658 \\
1,490 \\
781 \\
\mathrm{~b} \\
\mathrm{~b} \\
\mathrm{~b} \\
1,836 \\
250 \\
1,889 \\
2,592 \\
5,423 \\
2,832 \\
1008 \\
359 \\
2,100 \\
\end{array}$ & $\begin{array}{r}42,418 \\
2,0008 \\
17,648 \\
b \\
b \\
424 \\
1,224 \\
b \\
1,218 \\
1,722 \\
798 \\
b \\
b \\
b \\
1,841 \\
250 \\
2,159 \\
2,909 \\
7,141 \\
2,492 \\
2008 \\
405 \\
2,437 \\
\end{array}$ & $\begin{array}{r}50,982 \\
4,305 \\
17,648 \\
\mathrm{~b} \\
\mathrm{~b} \\
458 \\
1,136 \\
\mathrm{~b} \\
1,037 \\
1,753 \\
861 \\
\mathrm{~b} \\
\mathrm{~b} \\
\mathrm{~b} \\
2,344 \\
357 \\
2,367 \\
4,744 \\
9,697 \\
3,171 \\
500 \\
432 \\
891 \\
\end{array}$ & 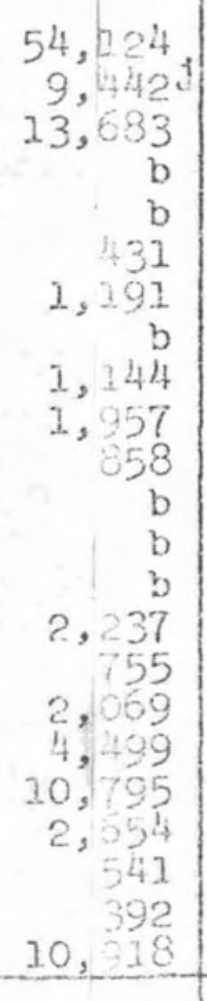 & $\begin{array}{r}58,294 \\
13,0005 \\
9,426 \\
\text { b } \\
\text { b } \\
449 \\
1,177 \\
396 \\
1,272 \\
3,5,16 \\
824 \\
\text { b } \\
\text { b } \\
\text { b } \\
2,466 \\
779 \\
2,648 \\
4,773 \\
13,743 \\
2,450 \\
580 \\
408 \\
25,387 \\
\end{array}$ & $\begin{array}{r}73,294 \\
18,6251 \\
18,624 \\
\mathrm{~b} \\
\mathrm{~b} \\
507 \\
681 \\
464 \\
1,187 \\
2,565 \\
898 \\
\mathrm{~b} \\
\mathrm{~b} \\
\mathrm{~b} \\
2,465 \\
734 \\
2,709 \\
5,587 \\
16,834 \\
2,335 \\
750 \\
431 \\
16,334 \mathrm{k}\end{array}$ & $\begin{array}{r}80,673 \\
23,032 \\
15,487 \\
b \\
b \\
498 \\
553 \\
382 \\
2,538 \\
2,492 \\
944 \\
69 \\
361 \\
b \\
2,538 \\
726 \\
2,655 \\
5,799 \\
18,674 \\
2,863 \\
642 \\
405 \\
b\end{array}$ & $\begin{array}{r}87,891 \\
26,443 \\
15,579 \\
\mathrm{~b} \\
\mathrm{~b} \\
516 \\
591 \\
410 \\
1,703 \\
2,760 \\
1,003 \\
87 \\
380 \\
\mathrm{~b} \\
2,527 \\
694 \\
2,273 \\
6,864 \\
22,013 \\
2,709 \\
887 \\
452 \\
\mathrm{~b} \\
\end{array}$ & $\begin{array}{r}90,271 \\
26,466 \\
16,431 \\
\mathrm{~b} \\
\mathrm{~b} \\
565 \\
710 \\
417 \\
1,671 \\
2,771 \\
1,051 \\
\mathrm{~b} \\
464 \\
\mathrm{~b} \\
2,562 \\
704 \\
2,379 \\
6,534 \\
23,027 \\
2,606 \\
1,056 \\
367 \\
26,956 \\
\end{array}$ & $\begin{array}{r}89,353 \\
24,000 \\
16,334 \\
b \\
b \\
632 \\
650 \\
546 \\
1,702 \\
2,954 \\
1,198 \\
b \\
494 \\
b \\
2,609 \\
742 \\
2,486 \\
7,338 \\
22,957 \\
3,029 \\
1,183 \\
377 \\
24,122 \\
\end{array}$ & $\begin{array}{r}90,000 \\
27,400^{1} \\
16,400 \\
\mathrm{~b} \\
\mathrm{~b} \\
\mathrm{~b} \\
700 \\
\mathrm{~b} \\
5,000 \\
1,200 \\
\mathrm{~b} \\
\mathrm{~b} \\
\mathrm{~b} \\
2,800 \\
\mathrm{~b} \\
2,500 \\
8,700 \\
24,000 \\
\mathrm{~b} \\
\mathrm{~b} \\
1,300 \\
\mathrm{~b} \\
\end{array}$ \\
\hline 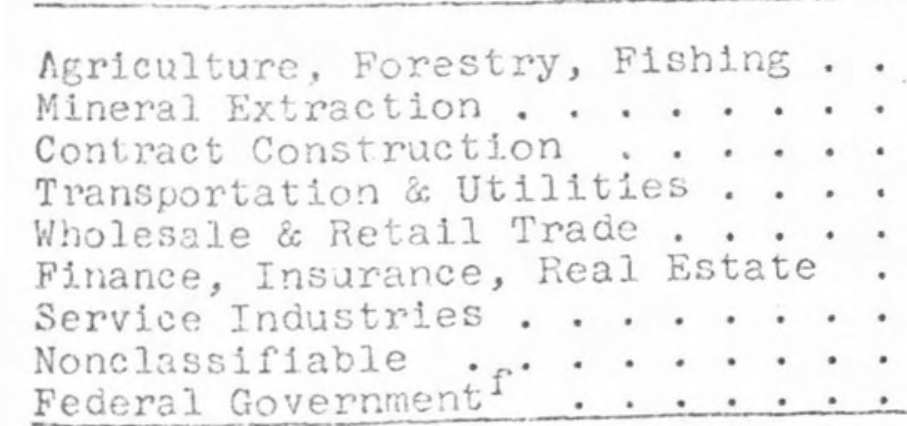 & $\begin{array}{r}290 \\
58 \\
8,236 \\
5,032 \\
28,475 \\
2,859 \\
7,127 \\
80 \\
\mathrm{~b}\end{array}$ & $\begin{array}{r}270 \\
40 \\
8,885 \\
5,501 \\
2,852 \\
2,934 \\
7,556 \\
89 \\
\mathrm{~b}\end{array}$ & $\begin{array}{r}268 \\
44 \\
7,871 \\
5,363 \\
21,109 \\
3,359 \\
8,043 \\
59 \\
0 \\
\end{array}$ & $\begin{array}{r}279 \\
50 \\
10,015 \\
5,341 \\
21,232 \\
3,616 \\
8,251 \\
50 \\
6 \\
\end{array}$ & $\begin{array}{r}339 \\
81 \\
11,106 \\
6,121 \\
23,494 \\
5,413 \\
9,830 \\
79 \\
0\end{array}$ & $\begin{array}{r}135 \\
13,395 \\
6,885 \\
25,853 \\
4,048 \\
11,019 \\
81 \\
\text { b }\end{array}$ & $\begin{array}{r}374 \\
101 \\
13,176 \\
7,421 \\
29,399 \\
4,629 \\
12,219 \\
95 \\
3,647 \\
\end{array}$ & $\begin{array}{r}14 \\
14,7 \\
7,7 \\
28,7 \\
5,7 \\
13, \\
3, \\
3\end{array}$ & $\begin{array}{r}698 \\
142 \\
16,595 \\
7,479 \\
31,200 \\
5,510 \\
16,41,5 \\
200 \\
4,260 \\
\end{array}$ & $\begin{array}{r}599 \\
86 \\
16,278 \\
8,316 \\
34,275 \\
6,427 \\
19,545 \\
174 \\
4,532\end{array}$ & $\begin{array}{r}86 \\
16,728 \\
8,725 \\
36,034 \\
6,858 \\
23,371 \\
220\end{array}$ & $\begin{array}{r}17 \\
8, \\
38 \\
7 \\
26\end{array}$ & $\begin{array}{r}20 \\
9, \\
41, \\
8, \\
30,\end{array}$ & $\begin{array}{r}19 \\
10 \\
46 \\
9 \\
32 \\
5\end{array}$ & $\begin{array}{r}\mathrm{b} \\
100 \\
19,900 \\
12,200 \\
48,900 \\
9,700 \\
50,100 \\
\mathrm{~b} \\
7,700 \\
\end{array}$ \\
\hline
\end{tabular}

totat

apata for the month of June; all other data for July.

Dota not available, insufficient, or no employment reported in category.

cSeasonal fluctuations not indicated.

$\mathrm{d}_{\text {Almost entirely motor vehicles. }}$.

probably inclupes ficures for oranance This category probably inoludes floures for category.
$\mathrm{f}_{\mathrm{Fe}}$ deral installations and Federal civtlian taployment; the latter as covered by Thtie XV of the Social Seourity Act. Total figure for San Jose SMSA does not include Federal government employment. Estimated from data for other montins and previous and succeeding years.

hLow July figures because of trade dispute.

includes some ordnance employment. 
June figures shown as estimate.

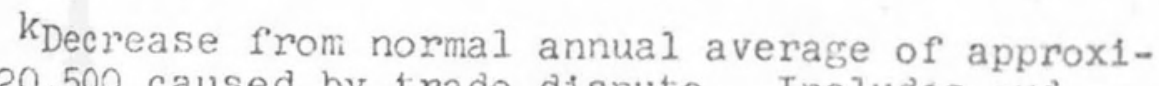
mately 20,500 caused by trade dispute. Includes ordnance and accessories.

Includes a small number of other durable goods employment.

Sources: Calculated from, California, Department of Employment, Research and Statistics Division, California Employment and Payrolls in 1951: A Study of Workers [and Wages] Covered by the California Unemployment Insurance Act. Classifled by Industry and County, Rept. No. 127, Pt. 14 (August, 1953), and Pts. 15c$20 c, 21 b, 21 c-22 c, 23 b, 23 c-25 c, 26 b$, and $26 \mathrm{c}-27 \mathrm{c}$ for the years 1952-1964; and California, Department of Industrial Relations, Division of Labor Statistics and Law Enforcement, California Labor Statistics Bulletin: Metropolitan Areas, July, 1965, p. 13. 
TABLS O

WAGES PAID IN MAJOR INDUSTRTAL GROUPS AND SELECTED SUBGROUPS IN THE SAN FRANCISCO BAY AREA DURING 1939, 1944, 1949, 1954, 1959 AND 1964 a

(In thousands of dollars)

\begin{tabular}{|c|c|c|c|c|c|c|c|c|c|c|}
\hline Industries & . & & & 1939 & 1944 & +2 & 1949 & 1954 & 1959 & 1964 \\
\hline 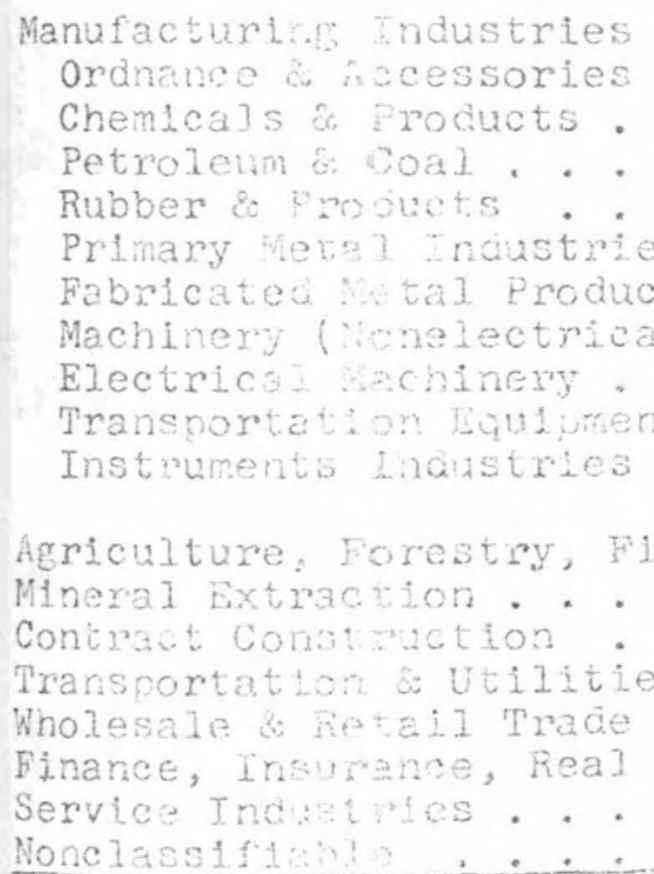 & 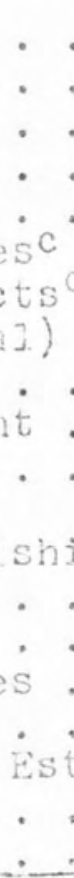 & 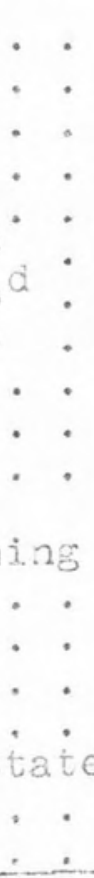 & 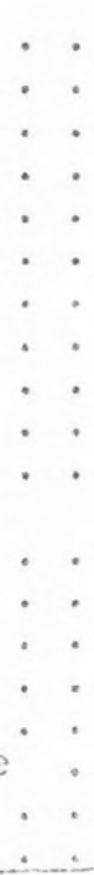 & $\begin{array}{r}\$ 205,090 \\
b \\
13,124 \\
11,708 \\
814 \\
27,912 \\
2,614 \\
8,730 \\
6,228 \\
b \\
b \\
b \\
1,952 \\
30,584 \\
66,215 \\
162,813 \\
44,788 \\
79,912 \\
15,600 \mathrm{e}\end{array}$ & $\begin{array}{r}985,056 \\
5,472 \\
28,590 \\
42,992 \\
1,928 \\
60,674 \\
9,404 \\
55,677 \\
17,614 \\
537,874 \\
b \\
1,973 \\
4,123 \\
126,507 \\
165,667 \\
349,207 \\
79,458 \\
110,049 \\
93,057\end{array}$ & & $\begin{array}{r}641,952 \\
127 \\
42,462 \\
53,482 \\
2,684 \\
42,711 \\
56,979 \\
49,789 \\
22,579 \\
17,875 \\
2,754 \\
5,227 \\
8,682 \\
213,526 \\
289,996 \\
677,173 \\
156,365 \\
233,072 \\
1,556 \\
\end{array}$ & $\begin{array}{r}999,997 \\
3,690 \\
63,255 \\
76,163 \\
6,133 \\
55,819 \\
96,472 \\
88,554 \\
62,401 \\
84,243 \\
4,955 \\
6,693 \\
7,680 \\
326,038 \\
406,631 \\
873,387 \\
242,971 \\
318,442 \\
1,533 \\
\end{array}$ & $\begin{array}{r}\$ 1,606,838 \\
117,119 \\
81,828 \\
93,350 \\
11,358 \\
89,408 \\
144,383 \\
122,509 \\
184,485 \\
105,801 \\
13,738 \\
12,585 \\
16,583 \\
511,367 \\
604,169 \\
183,837 \\
342,302 \\
514,019 \\
8,081 \\
\end{array}$ & $\begin{array}{r}\$ 2,154,388 \mathrm{f} \\
238,602 \\
97,809 \\
101,855 \\
14,564 \\
105,164 \\
170,784 \\
174,551 \\
294,589 \\
136,164 \\
26,344 \\
17,643 \\
21,982 \\
731,961 \\
795,310 \\
1,637,819 \\
506,211 \\
879,574 \\
27,215 \\
\end{array}$ \\
\hline & & & & & & & & & & \\
\hline
\end{tabular}

acalcunated from, California, Department of Employngnt, Researci and Statistics Division, Callfornia Employment and Psyol1s in 1939: A Study of Workers and Wares Covered by the Cal1fornia, 17,22, and 27 for the

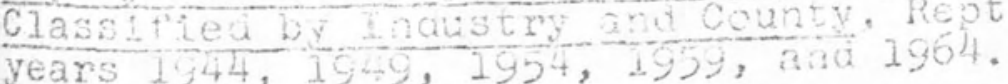

bata not available or insufficient.

cFor the years 1939 and 1944, this category was cifusfled as "Iron and Steel and Thelr Products." dFor the years 1939 and .1944 , this category was classlfied as "Nonferrous Metals and Thelr Products."

eIncludes total figures for Marin and Solano Counties.

fFigures are taken from "Miscellaneous Manufacturing" data for the San Jose SMSA, as they primarily represent data for the aerospace industry. 
TABLE E

BAY AREA PERSONAL INCOME AND NET BUYING POWER, 1950-1965

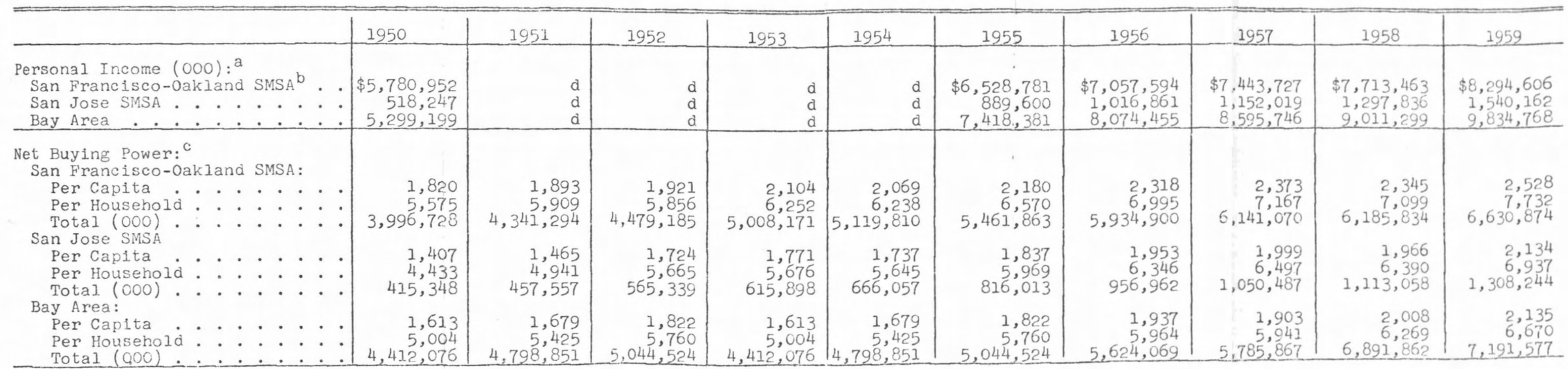

aCalifornia, Department of Finance, California Statistical

\begin{tabular}{|c|c|c|c|c|c|}
\hline 1960 & 1951 & 1962 & 1963 & 1964 & 1965 \\
\hline $\begin{array}{r}\$ 8,511,917 \\
1,776,654 \\
10,288,571 \\
\end{array}$ & $\begin{array}{r}\$ 9,007,501 \\
1,964,695 \\
10,972,196 \\
\end{array}$ & $\begin{array}{r}\$ 9,550,190 \\
2,206,812 \\
11,757,002 \\
\end{array}$ & $\begin{array}{r}\$ 10,254,626 \\
2,452,646 \\
12,707,272 \\
\end{array}$ & $\begin{array}{r}\$ 10,961,194 \\
2,672,053 \\
13,633,247 \\
\end{array}$ & $\begin{array}{r}\$ 11,736,845 \\
2,887,985 \\
14,624,830 \\
\end{array}$ \\
\hline $\begin{array}{r}2,728 \\
8,479 \\
7,660,774\end{array}$ & $\begin{array}{r}2,633 \\
7,986 \\
7,582,187\end{array}$ & $\begin{array}{r}2,673 \\
8,130 \\
7,034,307\end{array}$ & $\begin{array}{r}2,823 \\
8,554 \\
8,159,745\end{array}$ & $\begin{array}{r}2,953 \\
8,962 \\
8,702,853\end{array}$ & $\begin{array}{r}3,090 \\
9,360 \\
9,361,267\end{array}$ \\
\hline $\begin{array}{r}2,300 \\
7,396 \\
1,537,707\end{array}$ & $\begin{array}{r}2,359 \\
8,229 \\
1,687,679\end{array}$ & $\begin{array}{r}2,392 \\
8,318 \\
1,687,683\end{array}$ & $\begin{array}{r}2,489 \\
8,614 \\
2,056,913\end{array}$ & $\begin{array}{r}2,607 \\
9,014 \\
2,234,585\end{array}$ & $\begin{array}{r}2,733 \\
9,413 \\
2,467,999\end{array}$ \\
\hline $\begin{array}{r}2,514 \\
7,937 \\
9,198,481 \\
\end{array}$ & $\begin{array}{r}2,496 \\
8,107 \\
9,269,866 \\
\end{array}$ & $\begin{array}{r}2,532 \\
8,224 \\
8,721,990 \\
\end{array}$ & $\begin{array}{r}2,656 \\
8,584 \\
10,216,658 \\
\end{array}$ & $\begin{array}{r}2,780 \\
8,988 \\
10,937,438 \\
\end{array}$ & $\begin{array}{r}2,911 \\
9,386 \\
11,829,266 \\
\end{array}$ \\
\hline
\end{tabular}
Abstract, 1968, p. 55, for years 1960-1965.

bIncludes Solano County

coakland Chamber of Commerce, Research Department, 1967 Handbook: Co Oakland Chamber of Commerce, 1967), p. 3; San Jose Mercury-News, Market Memo: Current Trends and rospects in Metro San Jose and the Nation (San Jose, California, July, 1960), unpaginated, Sales Management, May 10, 1951, pp. 136 and 179; May 10, 1952, pp. 17 and and 218; May 10, 1953, pp. 181 and 252 ; May 10, 280; May 10, 1955, pp. 168 248; May 10, 1958, pp. 150 and 254; May 10, 1957, pp. 126 and 245; Ji2y 10, 1060, p. 98; May 10, 1961 , May 10, 1959, pp 126 and 609; June 10, 1963, pp. 195 and 562; June; June p. C-17.

d Data not available. 


\section{APPENDIX III \\ BAY AREA MANUFACTURING MARKETS}

Table

A. D1stribution of Total Employment to Initial

Demand Sectors and Local Industries and

Total D1rect and Indirect Employment to

Demand Sectors, by Broad Industry Groups:

San Francisco-0akland Metropolitan Area,

1959 . . . . . . . . . . . 201

B. Percentage of Sales to Major Markets by 46

Surveyed Bay Area Industries, by Size,

1955, 1960, and 1965 .......... 202

Bay Area Markets Quest1onna1re .. . . . . . 203 
TABLE A

DISTRIBUTION OF TOTAL EMPLOYMENT TO INITIAL DEMAND SECTORS AND LOCAL INDUSTRIES AND TOTAL DIRECT AND INDIRECT EMPLOYMENT TO LEMAND SECTORS, BY BROAD INDUSTRY GROUPS:

Percentages in paranthe METROPOLITAN AREA, 1959

(percentages in parentheses: Employment in thousands)

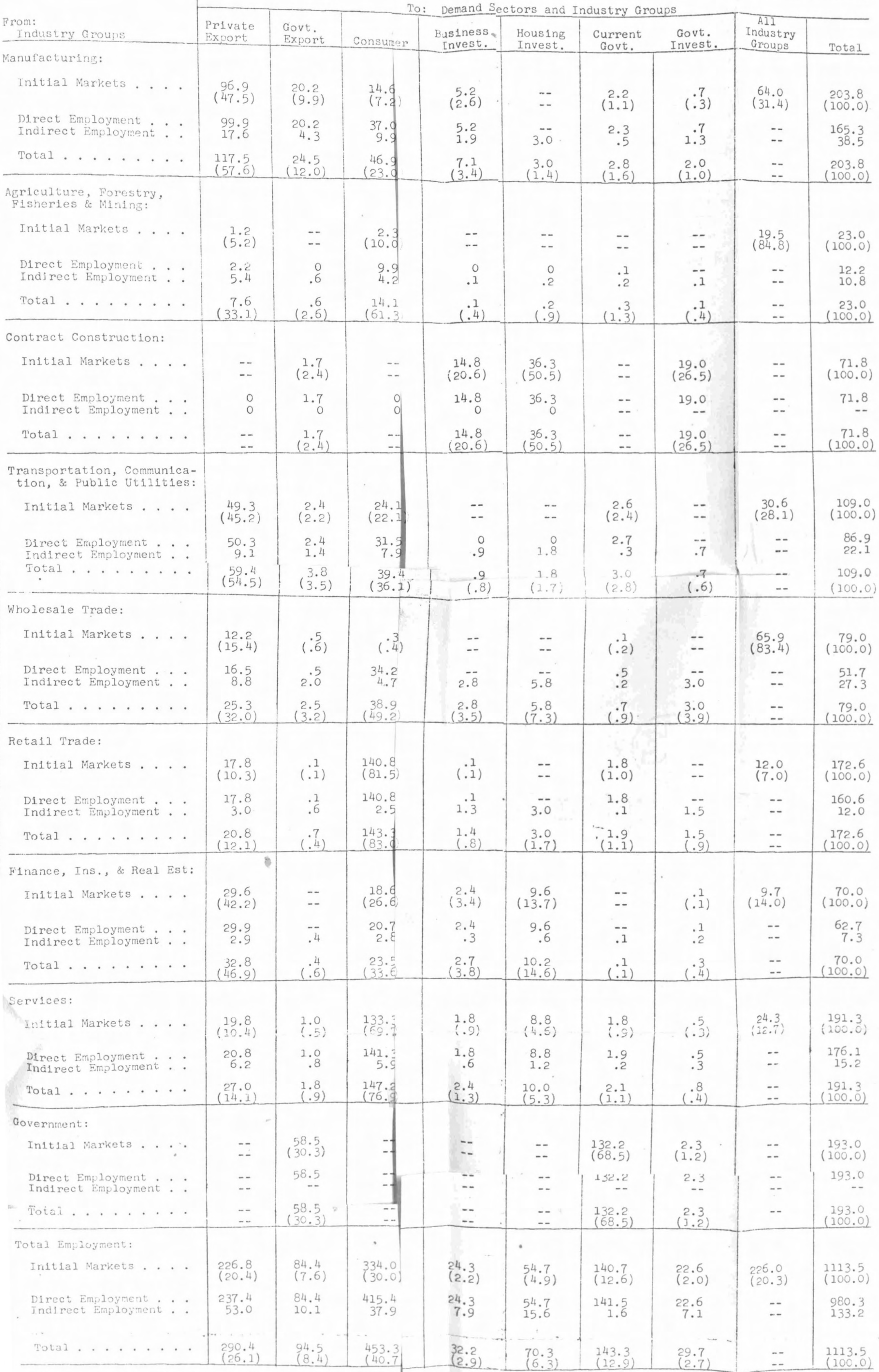

Source: California, Economic Development Agency, Ma tets for Califurnia Products: An Analysis of Sournes of Demand, 
TABLE B

EEFCENTAGE OP SALES TO MAJOR MARKEN'S BY 46 SURVEYED BAY AREA INDUSTRIES, 5Y SI20,

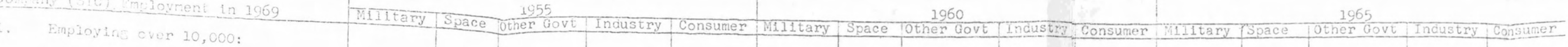

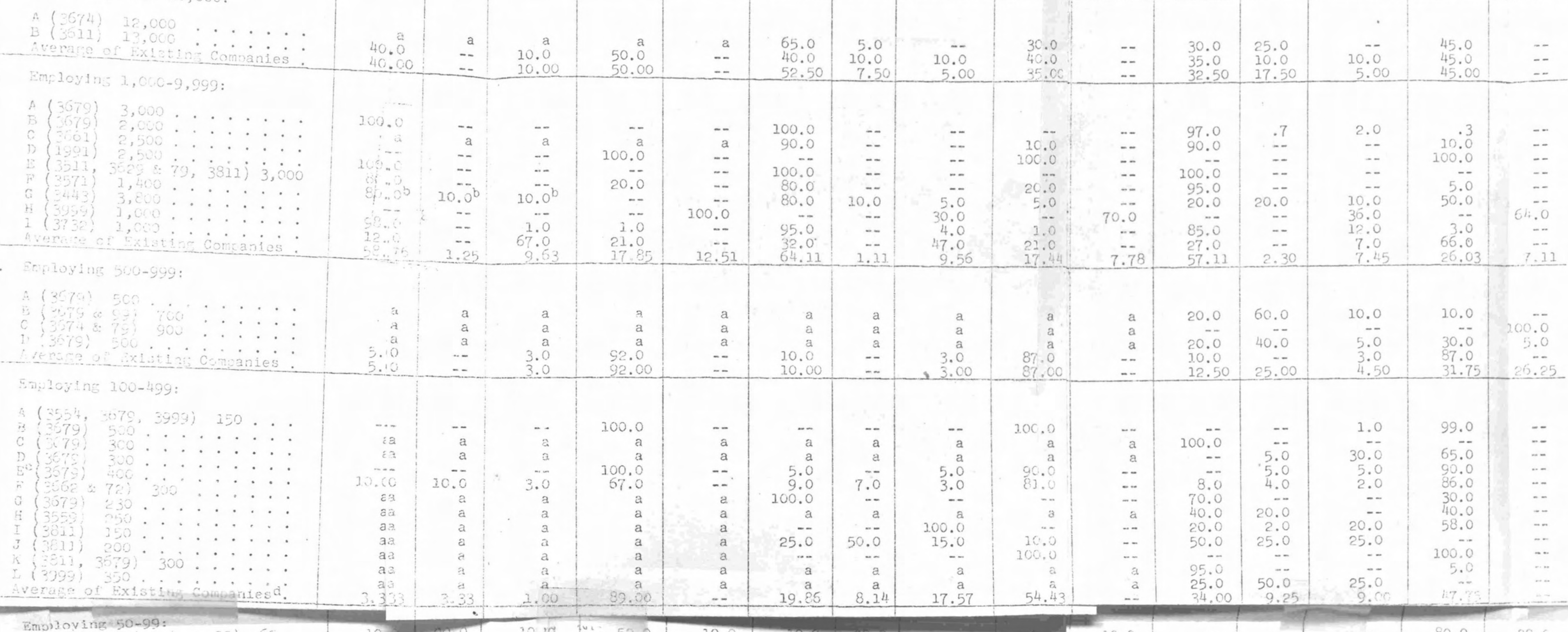

III. Emaloying under 25:
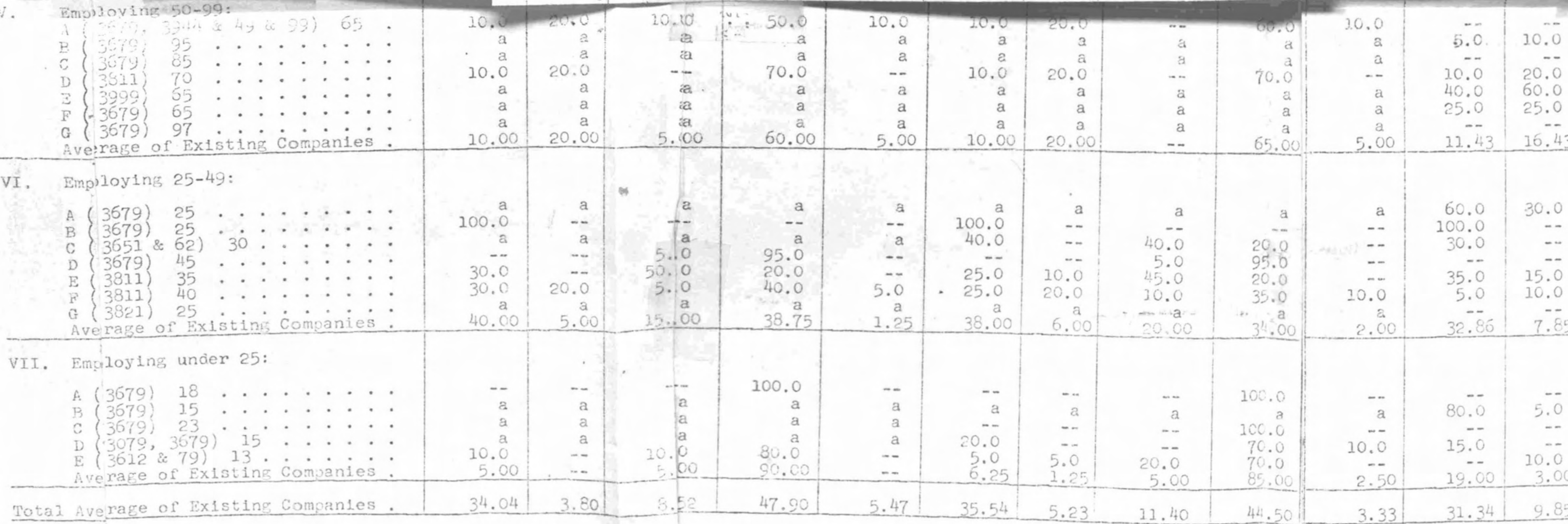

VI. Employing 25-49:

acompany not in existence.

aDoes not 44.50 
James C. Williams

215 Milbrae Lane, \#7

Los Gatos, California 95030

\section{Dear Sir:}

I am a graduate student in History at San Jose State College, currently working on a master's thesis tentatively entitled "The Impact of Federal Spending in the San Francisco Bay Area,

Because of understandable classifications on information pertaining to defense and space contracts, it has been difficult to obtain reliable information by which a substantiation of the partial dependency of the Bay Area upon federal spending may be made. Before moving on to a consideration of political and philosophical implications which may result from such an area dependency, study of the economic aspect must be completed. Therefore, a current area survey of markets will be helpful in supplementing other available information.

I would greatly appreciate your help in completing the attached sheets and returning them in the enclosed self-addressed envelope. Since this project is concerned with the Bay Area as a whole, replies will be treated confidentially. A total tabulation will be malled to you upon completion of the thesis.

Sincerely yours,

James C. W1lliams 
NOTE: This questionnaire applies only to the sales of the establishment(s) of your firm located in the San Francisco Bay Area (see definitions).

1. Please describe briefly the major groups of products of your establishment(s):

IN THE FOLLOWING QUESTIONS, IF YOU SELL TO WHOLESALERS PLEASE DISREGARD THIS FACT AND ESTIMATE WHERE YOUR WHOLESALER SELIS YOUR PRODUCT.

2. First, consider your total sales this past

Percentages year as going to two types of customers:

(2a) those located OUTSIDE of the San Francisco Bay Area plus all sales to the federal government.

(2b) those located INSIDE of the San Francisco Bay Area.

Estimate your sales between these groups:

(2a) Percentage sold OUTSIDE plus federal

(2b) Percentage soid INSIDE ..... Total 100\%

3. Taking a typical dollar of sales this past year estimated in 2a (outside plus federal government), how would you distribute this dollar of sales among the following groups?

(3a) sales to the federal government. . 4. Taking a typical dollar of sales this past
year estimated in $3 a$ (sales to federal
(s) government), how would you distribute this dollar of sales among the following?

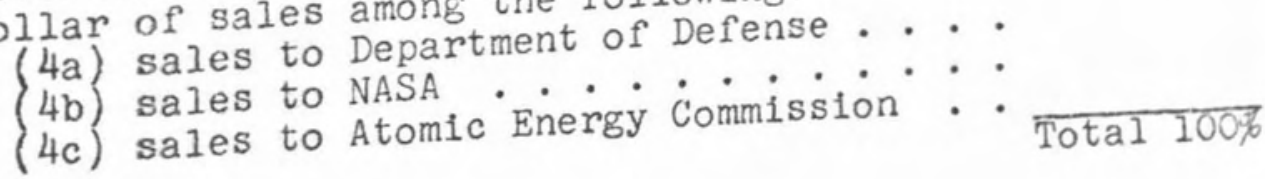
*Response to Item nos.
render the results insignificant. Consequently, these
results are not included in this paper. 
5. Taking a typical dollar of sales this past year estimated in $3 \mathrm{~b}$ (outside of the San Francisco Bay Area and excluding the federal government), how would you distribute this dollar of sales among the following areas?

(5a) sales to the Los Angeles-Long Beach

(5b) sales to the rest of Caifornia (omitting sales to Los Angeles-Long Beach and San Francisco Bay Area) . . . .

(5c) sales to the rest of the United States

(5d) sales to foreign nations.... Total 100\%

6. Taking a typical dollar of saies this past year estimated in $2 \mathrm{~b}$ (inside the San Francisco Bay Area), how would you distribute this dollar of sales among the following?

(6a) sales DIRECTLY to consumers (people) which do not go through retail outlets (6b) sales to state and local governments .
(6c) sales to San Francisco Bay Area firms
of capital goods; $1 . e$. machinery and equipment ...........

(6d) sales to San Francisco Bay Area firms of non-capital goods . . . . . Total 100\%

7. Taking a typical dollar of sales this past Taking a typical do (non-capital goods to
year estimated in 6d (now
local firms), how would you distribute this dollar of sales among the following San

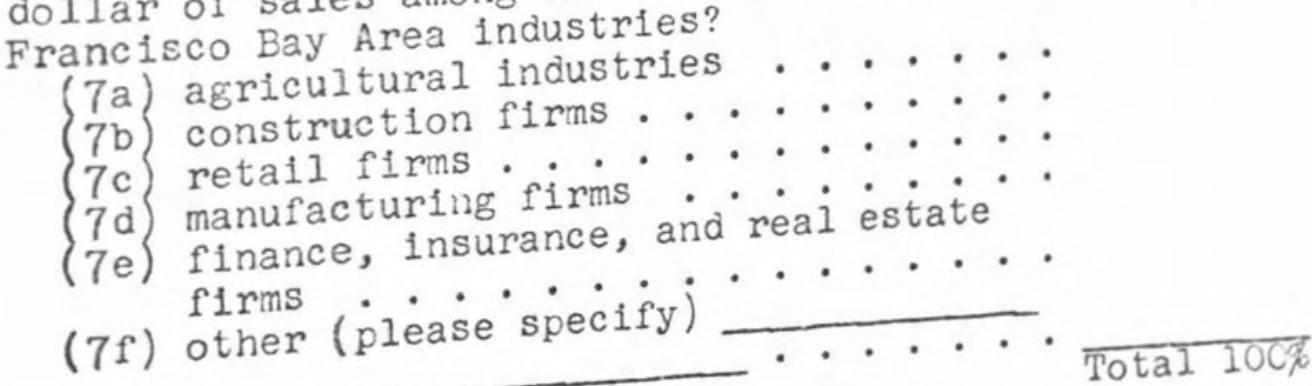

8. Taking a typical dollar of sales this past year estimated in $7 d$ (to manufacturing firms), how would you distribute this dollar of sales among the following San Francisco Bay Area industries?

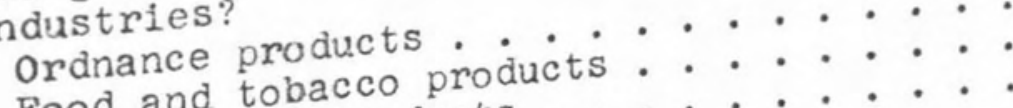
Food and tobacco productile mill products . . . . . . . Apparel and other garment propt furniture

(Continued on next page) 
(8 cont 1 nued)

Furniture and fixtures

Paper and paper products

Printing and publishing industries

Chemical products, Including drug, piastics, soaps, and fert1lizers

Petroleum refining industries

Rubber products

Leather and leather products

Stone, clay and glass products

Primary metal Industries (e.g., foundries,

steel plants). . . . . . . . . .

Fabrlcated metal products, except ordnance,

machinery, and transportation equipment.

Machinery, except electrical

Electrical machinery, equipment and supplies

Transportation equipment (vehicle, alrcraft, boats, rallroad equipment)

Professional, scientific, and control

Instruments; photographic and opt1cal goods; watches and clocks, etc. . . . .

Manufacturing 1ndustries not covered in the above (please specify)

9. In 1955 a typical dollar of sales of your

TotaI 100\%

flrm would have been distributed how among the following?

M111tary market. . . . . . . . . .

Non-m1litary space market........

Other government market.........

Industrial market. . . . . . . . . . . . .

Consumer market.......... $\cdot \frac{.}{\text { Total 100\% }}$

10. In 1960 a typical dollar of sales of your

f1rm would have been distributed how among

the following?

MI11tary market

Non-military space market........

other government market . . . . . . .

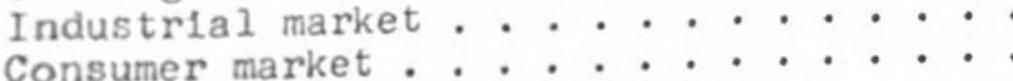

Consumer market.........

11. In 1965 a typical dollar of sales of your

firm would have been distributed how among the following?

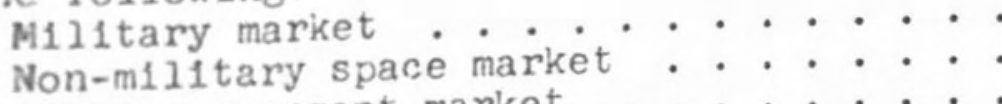

other government market . . . . . . .

Industrial market . . . . . . . . . . .

Consumer market

Total 100\% 
12. In order to give some idea of the size of the establishment(s) covered by this questionnaire, would you please indicate the approximate number of people you employ: . . . . . .

Area definitions --

San Francisco Bay Area includes Alameda, Contra Costa, Marin, San Francisco, San Mateo, Santa Clara, and Solano Counties.

Los Angeles-Long Beach Area includes Los Angeles and Orange Counties.

other definitions --

Sales is the total dollar volume of your firm's sales. Capital goods includes machinery and equipment, with a life of more than one year, used to produce other products.

Non-Capitai goods includes all other products, excluding capital goods. 


\section{APPEVDIX IV \\ BAY RREA DEFE:ISE-SPACE CONTRACTS}

Table:

A. Pefense and Space Contracts Let to Bay Area W1:Ti3 by To-Diflt Standard Industrial

Classirication (SIC), in FY 1960, FY 1962,

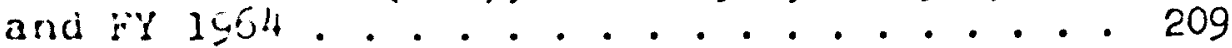

33. Lay Area referse-Space Contractors: Bay Area and :at1o:mide LOD Contracts Let, Selected Years............... 210 
DEFENGE AWD SPACE CONTRACTS LET TO BAY AREA FIRMS BY TO-TTCIT STANDARD INDUSTRIAL

ClASSIFICATIOA (SIC), IN FY 1960, FY 196? AND FY 1964

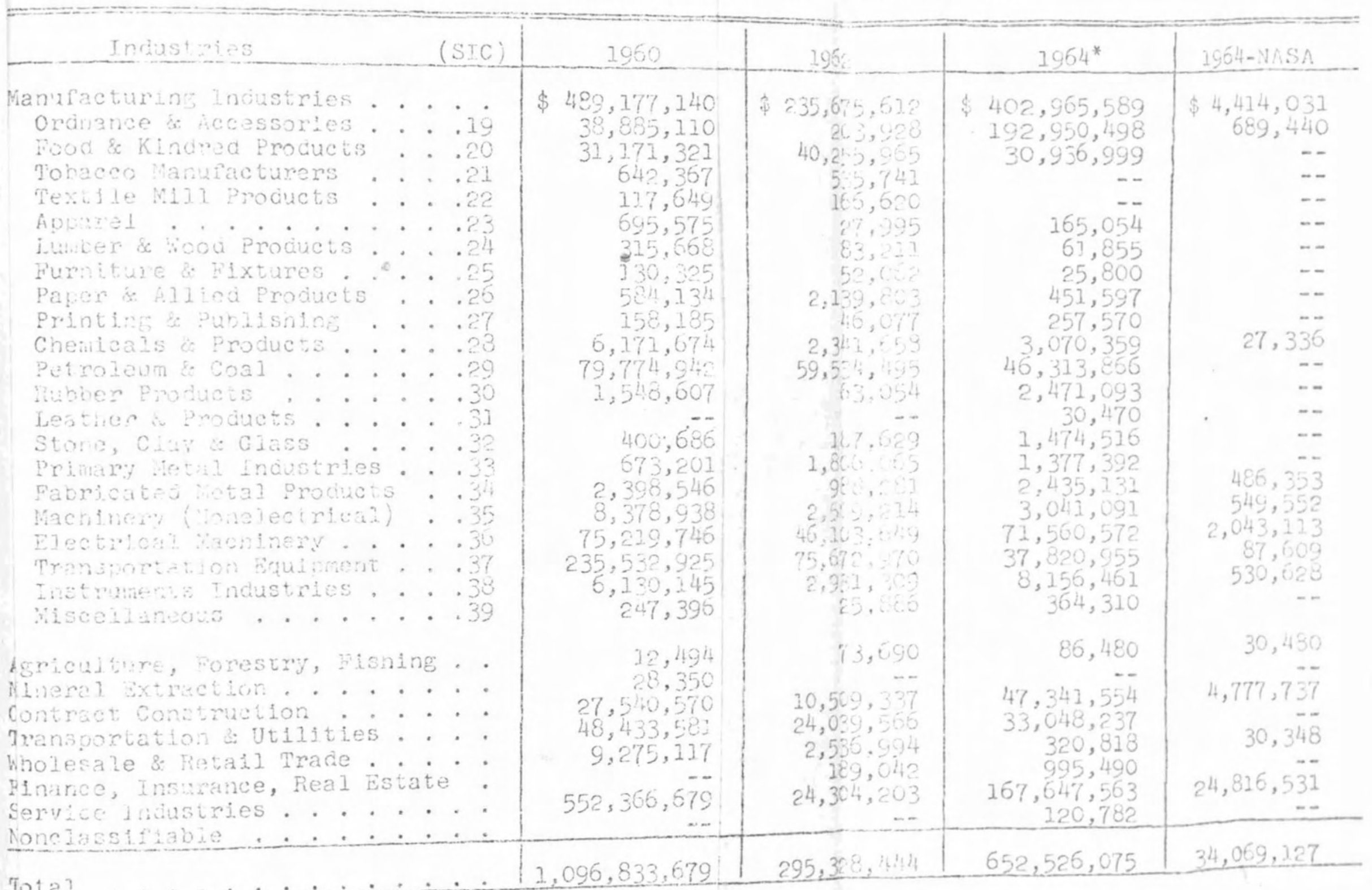

*Includes figures for NASA contracts.

Cajonlated from:

Watter Isard and James Ganschow, Awaros of Prime Military Contracts by County, State, and Metropolitan Area c. the United States, Fiscal lear Renrsy vania 1960$)$ pp. $23-25$ and $27-0 ;$ Valter Isard and Gerald J. Karaska, Unclassified Defense Contract: A Mards by County, State, and

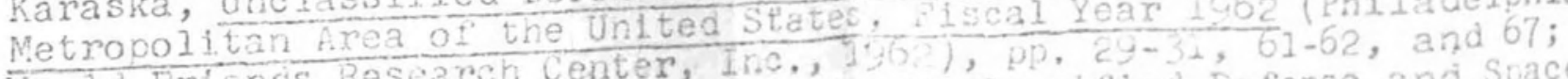

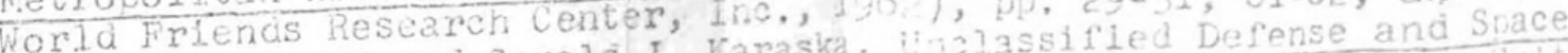
and Walter Isard and Gerald J. Karask, Contracts: Awards by County, State, a la

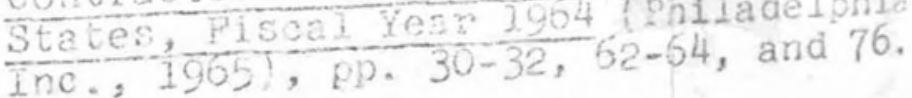


TABLE B

BAY AREA DEFENSE-SPACE CONTRACTORS: BAY AREA AND NATIONVIDE DOD CONTRACTS LET, SELECTED YE $l$ RS

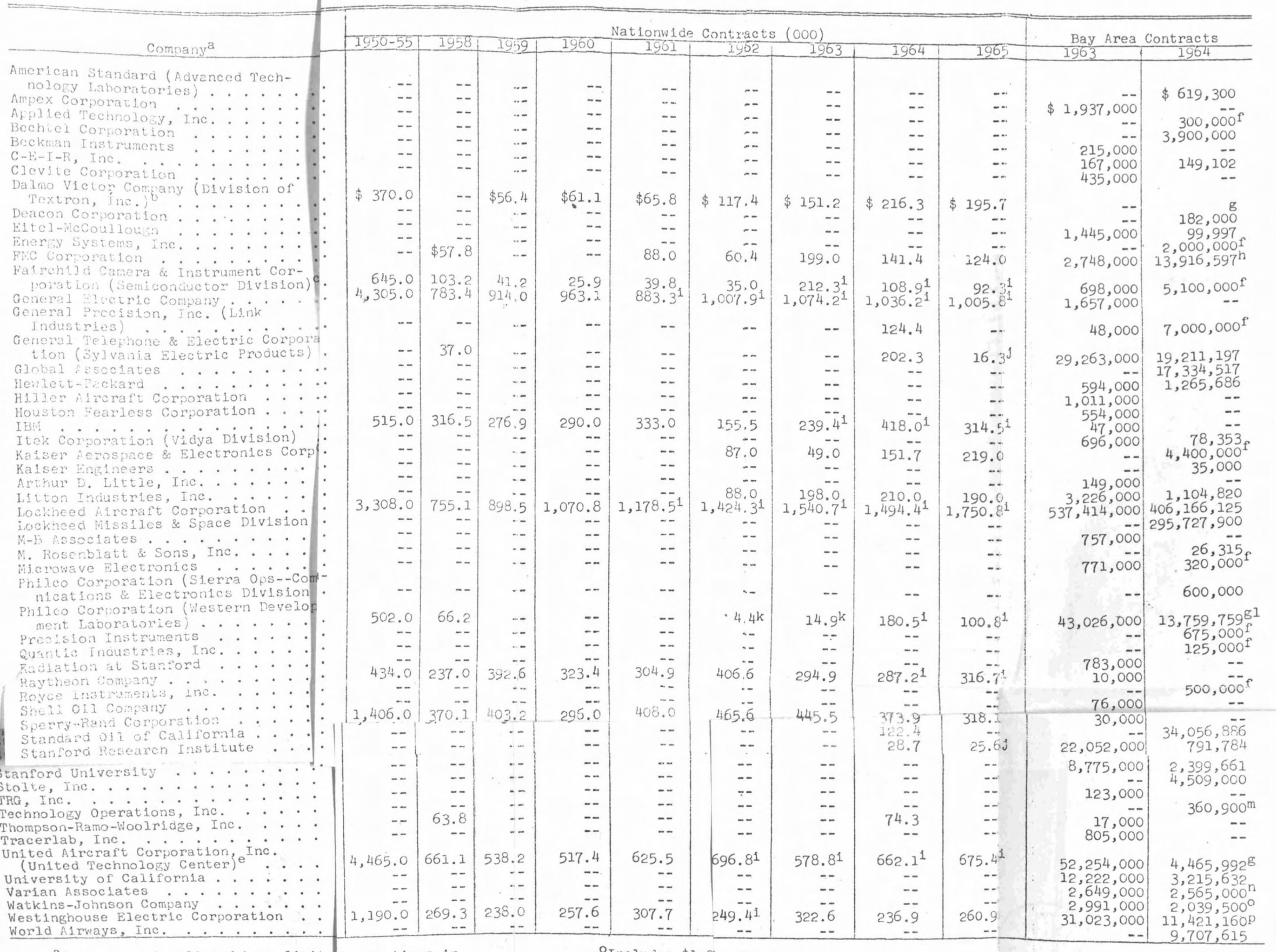

a Some companies listed have limitep operations in the Bay Area, and some are no longer lopated in the area.

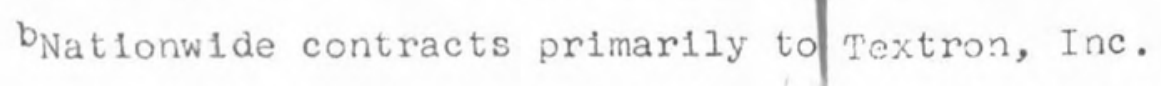

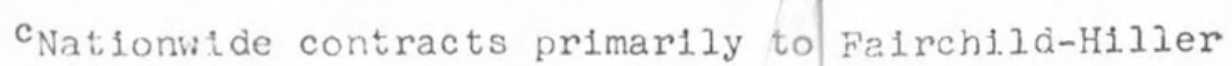
Corporation.

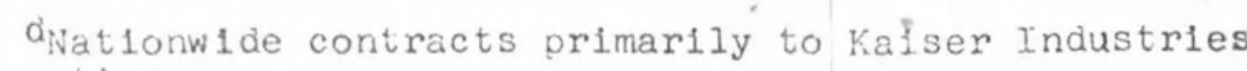
Corporation.

eNationwide contracts primarily to united Aircraft.

fFigure shown is for subcontracts.

gother contracts of undisclosed value not shown.

${ }^{h_{I n c l u d e s}} \$ 2,000,000$ in subcontracts.

1 Includes contracts let by NASA.

only .

$J_{\text {Figure shown went to California based operations }}$

kASA contracts only.

${ }^{1}$ Includes $\$ 150,000$ in subcontracts

mincludes $\$ 69,000$ in subcontracts.

${ }^{n}$ Includes $\$ 550,000$ in subcontracts.

Includes $\$ 1,941,000$ in subcontracts.

pIncludes $\$ 360,000$ in subcontracts.

Sources:

Aerospace Industries Association of America, Inc.,

Aerospace Fact; and Fizures (Fallbrook, California:

Aero Publisher, Inc., 1963), pp. 42 and 85, and

editions for 1966, pp.' 98-99', and 1967, pp.98-99;

California, Debartment of Finance, California

Statistical Abstract, 1966 (Sacramento, 1966),

p. 150; Congressional Quarterly Service, Legisla-

sional Quarter.y Service, 1964$),$ p. 26 , and 2 nd

ed., 1968, pp. 56, and 58-59; Defense industry

Bulletin, Janus ry, 1965 and succeeding editions

1964, and succeding Miss1les and Rockets, July,

1964, and succeding editions through June, 1965;

Holt, Rinehart, Our Depleted Society (New York:

U.S., Congress, and Winston, 1965), pp. 330-42;

nomi.c Impact of Vietnam Spending Committee, Eco-

the Joint Economic Committee goth Cong

sess., 1967, I, p. 276; and U.S. 90 th Cong., Ist

Committee on Appro. 276; and U.S., Congress, House,

Appropriations for 1958 , Hearings, before a sub-

committee of the Committee on Appropere a sub-

House of Representatives, 85th Cong., lst sess.,

1957, I, pp. 76..77. 


\section{SELECTED BIBLIOGRAPHY}

In research wide use was made of government publications, newspapers, other published materials, and personal interviews and surveys. It should be noted that the San Jose liercury-News' clipping files were organized in such a way as to indicate only the dates of articles; therefore, page numbers of articles have not been cited. Several manufacturers indices were inftlally used during the market survey discussed in Chapter $V$, and these sources appear under "Almanacs and Handbooks" in the following list of sources consulted.

\section{MANUSCRIPTS}

Pett1t, Russell E. "Moffett Field." San Jose, California: San Jose Chamber of Commerce, March 4, 1955. An unpaginated MS in the 1955 clipping files of the San Jose Mercuiry-News. (Typewritten.)

San Jose Mercury-News. Untitled fact sheet. Mercury-News clipping files, 1955. (Typewritien.)

\section{GOVERNMENT DOCUMENTS}

\section{UNITED STATES DOCUMENTS}

Arms Control and Disarmament Agency. Economic Impacts of

Disarmament. Washington, D.C.: Government Printing office, January, 1962. 
- The Economic and Soclal Consequences of DisarmaGeneral of the Unt ted inquiry of the secretaryGovernment Printing office Mashington, D.C.:

Congress House of Repre

House of Representatives. Committee on AppropriaHearings, before a subcomittee of the Appropriations, House of Representatives Committee on

lst sess., II, 1957 .

- Jolnt Economic Committee. Background Material on

Economic Aspects of Military Procurement and Supply.

- Joint Economic Committee. Economic Effect of Vietnam Spending. Hearings, before the Jolnt Economic Commltee, Soth Cong., ist sess., 1967, 2 vols.

Joint Economic Committee. Economic Indicators;

June, 1969. 91st Cong., Ist sess., 1969.

Joint Economic Committee. Economics of Military

Procurement. Hearings, before the Subcommittee on

Economy in Government of the Joint Economic Committee,

goth Cong., 2 d sess., 1969, pt. 1.

- Joint Economic Commtttee. Subcommittee on Economy

in Government. Report: The Economics of Military

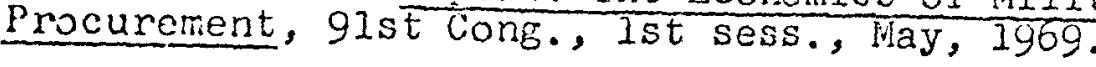

- Senate. Committee on Foreign Relations. Control and Recuction of Armaments. Hearings, before a subcommittee of the Comittee on Foreign Relations,

Senate, 85th Cong., 2 d sess., 1956, and 85th Cong.,

lst sess., 1957.

- Senate. Select Committee on Small Business. Small Business Conversion Problems--1954. Hearlngs, be fore the Select Committee on Small Business, Senate, $88 \mathrm{th}$ Cong., 2 a sess., 1964.

Department of Commerce. Future Development of the San Franc1sco Bay Area, i960-2020. Washington, D.C.: Government Printing ofilce, 1959.

- Bureau of the Census. Historlcal Statistics of the Und ted States: Colonial Times to 1957. Washıngton, D.W.: Government Printing office, 1960.

- Bureau of the Census. Historical Statistics

of the United States: Continuation to 190 and 
Revisions. Washington D.C.: Government Printing Bureau of the Census. Census of Manufacturers, 1963. Washington, D.C.: Government Printing office,

- Bureau of the Census. Current Population Reports: Population Estimates. Series P-25, Nos. 229 and 324. Washington, D.C.: Government Printing office, January 20 and May 22, 1966.

Economic Development Administration. Industrial Location as a Factor in Regional Economic Development.

- Economic Development Administration. Report of the Independent Study Board on the Regional Effects of Government Procurement and Related policies. Washington, D.C.: Government Printing Office, 1967.

- Orfice of Business Economics. 1967 Business Statistics: A Supplement to the Survey of Current Bus1ness. Washington, D.C.: Government Printing office, 1967.

Department of Defense. Small Business and Labor Surplus Area Specialists Desirnated to llelp the Eusinessman. Washington, D.C.: Government Printing office, 1967.

Department of Labor. Bureau of Employment Security. Area Manpower Guldebook: 174 Metropolitan Labor Market Areas. Vashington, D.C.: Government Printing ofrice, 1957 .

President's Committee on Economic Impact of Defense and Disarmament. Report. Washington, D.C.: Government Printing of fice, July, 1965.

\section{STATE AND LOCAL DOCUMENTS}

California. Assembly. Interim Committee on Ways and Means. The Impact of Federal Spending in Calfisornia. Report of 'che Subcommittee on Economic Development of the Interim Committee on Ways and Means, 1965.

Department of Employment. Division of Research and Statistics. Employment and Payrol]s: San Francisco-Qakland Labor Market Area, 1958-1904. Rept. No. 127 e, No. 1. Sacramento, 1967. 
Department of Employment. Research and Statistics. Community Labor Market Surveys, California, 1952.

Sacramento, 1953. (Mjmeographed.)

- Department of Employment. Research and Statistics

Division. California Employment and Pavrolls in 1939: A Study of Worker's [and Wages] Covered by the California Unemployment Insurance Act. Classif'ied by Industry and by County. Rept. No. 127, Pt. 2 . August, 1941. (And successive editions for the years 1940-1964, Pts. 3-27.)

- Department of Employment. Research and Statistics Section. East Bay Manoower Survey, Alameda County, 1956-71. San Francisco, 1967.

- Department of Employment. Research and Statistics Section. Estimated Employment, Unemployment and Labor Force: San Jose Metropolitan Area, 1949-1968. Series of March, 1968. Sacramento, January, 1969.

- Department of Employment. Proceedings of the Governor's Conference on Employment, December 5-6, 1949. Sacramento, 1950.

- Department of Finance. California Population, 1967. Sacramento, 1967.

- Department of Finance. California Statistical Abstract, 1958. Sacramento, 1958. (And successive editions for the years 1964, 1966, and 1968.)

- Department of Finance. State office of Planning. California State Development Plan Program: Progress Report and Summary Interpretations of phase I Studies. Sacramento, February, 1965.

- Department of Industrial Relations. Division of Labor Statistics and Law Enforcement. Callfornia Labor Statistics Bulletin: Metropolitan Areas. Sacramento, July, 1965.

Department of Industrial Relations. Division of Labor Statistics and Research. Employment and Earnings in the California Aircraft Industry, 1940-53. Sacramento, 1954.

Department of Industrial Relations. Division of Labor Statistics and Research. Employment Trends in California. Sacramento, November 4, 1954 . (Mimeographed.) 
- Department of Industrial Relations. Division of Labor Statistics and Research. Trends in Aerospace and Federal Government Employment. Sacramento, January 28, 1964.

- Economic Development Agency. Markets for Cal1fornia Products: An Analysis of Scurces of Demand, by $W$. Lee Hansen, R. Thayne Robson, and Charles $M$. Tiebout. Sacramento, 1961.

- Employment Reiations Agency. Englneering Employment in Califorria: A Conference by the California Society of Professional Engineers and the California State Employment Relations Agency. Transactions. Sacramento, 1906 .

- Governor. Economic Report of the Governor, 1968. Sacramento, February, 1968.

- Governor's Commisston on Metropolitan Area Problems. Metropolitan California. Edited by Ernest A. Engelbert. Sacramento, 1961.

- Senate. Fact-Finding Committee on Commerce and Economic Development. Final Report. Sacramento, 1957.

State Office of Planning. California State Development Plan Program: Phase II Report. Sacramento, 1968.

State Planning Board. An Economic and Industrial Survey of the San Francisco Bay Area, by Rooert Debois Calkins ana Walter E. Hoady, Jr. Sacramento, 1941 .

- State Reconstruction and Reemployment Commission. Report and Recommendations for the Period Ending December 31 , 1944 . Sacramento, 1945 . (And succesDecember, 1946.)

Santa Clara County. Planning Commission. Master Plan of
Alrports, Santa Clara County, California. San Jose, Califorria, December, 1946.

Planning Department. A Study of the Economy of Santa Clara County, Californla, Part l. San Jose, California, 1967. 


\section{6}

- Planning Department. "A Study of the Local

Impacts of Research and Research-based Manufacturing:

Santa Clara County, Callfornia. Summiny, "by Charies

T. Stewart. Inio Comnentary. San Jose, California,

Narch, 1967.

- Planning Department. Background: Santa Clara

County, California. A Sumary overview of the

Location, Toposmapny, Climate, population, Income.

Economic History, Principle Economic Activities,

Lador Force, Eonomlc problems and Resources for

Development in Santa Clara County, California. San

Jose, California, December, 1966.

Planning Department. Facts and Forecasts: A Supplement to tre General Plan of Santa Clara County. San Jose, Calitornia, october, 1900.

\section{ALMANACS AND HANDBCOKS}

Aerospace Industries Associations of America, Inc. Aerospace Facts \& Figures: 1963. Fallbrock, California: Aero Fublishers, Inc. 1963. (And successive editions for 1966 and 1967.$)$

Bay Area Council. Day Area Manufacturers Directory, 1952. San Francisco, 1962 . cisco Bay Area. San Francisco, 1964 .

Callfornia Marufacturers Association. California Manufacturers Annual Register, 1963. Los Angeles: TimesMirror eress, 1963. (And successive editions through 1957.)

Contacts Influential International, Inc. Reference Book. San Francisco: Contacts Influential International, Inc., 1957.

Greater San Jose Chamber of Commerce. Industrial Department. Directory of Manufacturers and Wholesalers of Santa Clara County. San Jose, California: Greater San Jose Chamber of Commerce, [1962].

- Industrial Department. Industrial Guide: Listing Firms with 50 or Nore Employees, 1958. San Jose, California: Greater San Jose Chamber of Commerce, 1958. (Arid 1962 edition.) 
- Industrial Department. Manufacturers and Wholesalers Directory of Santa Ciara County, Calliornia. San Jose, Calitornia: Greater San Jose Chamber of Commerce, [1957].

Oakland Chamber of Commerce. Research Department. 1967 Hancbook: Comuarative Data, Bay Area Counties. Oakland, California: Oakland Chamber of Commerce, 1967.

San Francisco Chamber of Commerce. Industrial Department. San Francisco Bay Region Space Age and Electronic D1rectury. San Francisco: San Francisco Chamber of Commerce, 1962.

Santa Clara County Chambers of Commerce, Inc. Dlrectory of Manufacturers, Santa Clara County. San Jose, CaIfornia: Santa Clara County Chambers of Commerce, Inc., [1968].

NEWSPAPERS

Christian Science honitor, January 8 and May 28, 1969. San Jose Mercury, 1956-1969.

San Jose :News, 1950-1968.

Wall Street Journal, January 12, 1965.

PERIODICALS AND MAGAZINES

"Business Leaders Find Outlook Bright for 1955." Fortnight, January 5, 1955, pp. 9-12.

Clayton, James L. "The Impact of the Cold War on the Economies of California and Utah, 1946-1965." Pacific HistoricaI Review, XXXVI (November, 1957), 449-73.

Cone, John W. "Employment Trends in the San Jose Metropolitan Area." Northern California Real Estate Report

( 3 d Quarter, 1964), 21-29.

Defense Industry Bulletin, January-June, 1965.

February, 1960-July, 1966. 
"Flve Perlods of Growth." Federal Reserve Bank of San Francisco: Monthly Review, December, 1965, pp. 216-

Gershenson, Maurice I. "Wartime and Postwar Employment Trends in California." Monthly Labor Review, LXIV (April, 1947), 576-88.

Goldberg, Michael A., and Walter, Gerald R. "Forecasting Employment and Industrial Location in the San

Francisco Bay Area." California Management Review, XI (Summer, 1968), 13-26.

Goodman, Paul. "A Causerie at the Military-Industrial." The New York Review of Books, IX (November 23, 1967),

Jensen, George. "Information on the Impact of Defense Expenditures: A Comment." Quarterly Review of Economics and Business, VI (Fal1, 1966), 78-81.

Keane, Kevin. "Cost of the Arms Race." America, October 2, 1965, pp. 372-75.

Lafferty, C.D. "Industrial Development Trends." Bay Area Reai Estate Report (4th Quarter, 1959), 83-86.

M1ssiles and Rockets, July, 1964-June, 1965.

"Mob1lizing for National Defense." Survey of Current Business, February, 1952, pp. 1-4.

Mosbaek, E. J. "Information on the Impact of Reductions in Defense Expenditures on the Economy." The Quarterly Review of Economics and Business, V (Fall, 1965), $47-67$.

"Northeast of Saigon." Federal Reserve Bank of San Francisco: Monthly Review, June, 1966, pp. 115-19.

"Paradox in the West." Federal Reserve Bank of San Francisco: Monthiy Review, March, 1965, pp. 58-62.

Peterson, Richard S., and Tiebout, Charles M. "Measuring the Impact of Regional Defense-Space Expenditures." The Review of Economics and Statistics, XIVI (November, J.964), 421-28. Sales Management, May 10, 1951-1959; July 10, 1960; May 10,
$1961 ;$ and June 10, 1962-66. 
San Francisco Chamber of Commerce. Research Department. San Francisco and the Bay Area: Economic Survey and

Stedman, Frank H. "The California Peninsula: Laboratory of the New Industrial Age." Industrial Development and Manuracturers Record, October, 1963, pp. 33-48.

Watkins, Harold D. "California Effort is Key to Growth Area." Aviation Week and Space Technology, February 7, 2966,

Weldenbaum, Murray L. "Measurements of the Economic Impact of Defense and Space Programs." The American Journal of Economics and Soclology, XXV (October, 1966),

"West Coast Aviation: Higher and Higher, Faster and Faster." Fortnight, May, 1956, pp. 2l-27.

\section{MONOGRAPHS AND SPECIAL STUDIES}

Arnold, Fobert K., et a1. The California Economy, 1947-1980. Menlo Park, California: Stanford Researci Institute, 1960.

BaIdwin, William L. The Structure of the Defense Market, $\frac{1955-1954}{\text { Press, } 1967 .}$ Durham, North Carolina: Duke University

Bank of America. Economics Department. Signiflcance of Military Installations for Califorila's Economic Growth, 1930-1952, by Sterling L. Brubaker. San Francisco, 1955 .

- Focus on San Francisco-0akland Metropolitan Area: An Economic Study Prevared by Bank of America N.T. Ec S.A. San Franc1sco, 1967. - Focus on Santa Clara County: An Economic Study Prepared by Bank of America N.T. \&. S.A. San Francisco, 1964 and 1969.

Bank of California. Pacific Coast Markets and Business. May, 1966.

Benoit, Emlie. "Economic Adjustment to Disarnament." Disarmament and the Economy. Edited by Emile Benolt and Kenneth E. Eoulding. Now York: Harper and Row, Publishers, 1963. 
Bolton, Roger E. Defense Purchases and Reglonal Growth.

Burdick, Eugene. "From Gold Rush to Sun Rush." The Cal1. Edited by Co., 1966.

Brubaker, Sterling I. "The Impact of Federal Government Activities on California's Economic Growth, 1930 1956." Unpublished Ph.D. dissertation, University of Callfornia, Berkeley, 1959.

California. State Chamber of Commerce. "Economic Survey of California and Its Courties." California Bluebook, 1942. Sacramento, 1942 (And successive editions

Summary of "The Callfornia Economy, 1947-1980." San Francisco: California State Chamber of Commerce,
1961.

Chamber of Commerce of the United States. Economic Research Department. What New Industrial Jobs Mean to a Community. Washington, D.C.: United States Chamber of Commerce, 1959.

Congressional Quarterly Service. Legislators and the Lobbyists. Washington, D.C.: Congressional Quarterly Service, 1964 and 1968.

Cook, Fred J. The Warfare State. New York: The Macmilian Co., 1962 .

Crappuchettes, Paul W. "The Stabilization of Engineering Employment by Correction of the Factors Producin? Instablity." Proceedings of the National Symoosium on Stabilization of Engineering and Scientific Employment in Industry. San Jose, California: Manpower Research Group, Center for Interdisclplinary Studies, San Jose State College, 1966, pp. 87-93.

Crocker Citizens National Bank. California's Economic Diversity. San Francisco, [1954].

Cunningham, W1lliam Glenn. The Alrcraft Industry: A Study In Incustrial Location. Los Angeles: Lorrin A. Morrison, Publisher, 1951.

Engelbert, Ernest. "The Federal Government and Californla's Growtn." The California Governmental Process: 
Problems and Issues. Ealted by Eugene $C$. Lee. Boston: Little, Erown \& Co., 1966.

Etzion1, Amita1. The Moon-doggle: Domestic and International

Implications of the Space Race. Garden City, New

Freeman, Ralph E., ed. Postwar Economic Trends in the United States.

Gershenson, Maurice I. Evaluation of Bay Area Economic Studies: Highlights and Summary. Menlo Park, Calirornta: Stanford Researeh Institute, 2968.

Hamilton, James W., and Bolce, William J. Gateway to Victory. Stanford University Press, 1946.

HLrsch, Werner $2 .$, and Baisden, Richard N., eds. California's Future Economic Growth. Berkeley: Diablo Press, 1965.

Howell, Rlchard P.; Breswick, William N.; and Wenrlck, Ernest D. Economic Impact of Defense $R \& D$ Expenditures: In Terms of Value Added and Employment. Menlo Park, Calfioria: Stanford Research Institute, 1965.

Isard, fiater, and Ganschow, James. Awards of Prime Military Contracts by County, State and Metropolitan Area of the United States, Fiscal Year 1960 . Philadelphia: Reglonal Science Research Institute, University of Pennsylvania, 1960.

- and Karaska, Gerald J. Unclassifled Defense Contracts: Awards by County, State and Metropolitan Area of the United States, Fiscal Year 1962. Philadelphia: World friends Research Center, Inc., 1962.

- Unclassified Defense and Space Contracts: Awards by County, State and Metropolitan Area of the Undted States, Fiscal Year 1964. philadelphia: World Friends Researci Center, Inc., 1965.

Kendrlck, M. Slace. "A Century and a Half of Federal Expenditures." Occasional Paper 48 (Revised). New York: National Bureau of Economic Research, Inc., 1955.

Lindner, Carl. "Dlversiflcation Progress and the San Francisco Bay Area Electronics Industry." Unpublished M.A. thesis, San Jose State College, 1967. 
Loomba, R. P. An Examination of the Englneering Profession.

San Jose, California: Manpower Research Group, College, 1968.

- "A Study of the Re-employment and Unemployment

Experiences of Engineers and Scientists Lald off in

62 Aerospace and Electronics Companies in the San

Francisco Bay Area during 1963-65." Proceedings of the Natlonal Symposium on Stabilization of Engineering and Scientifle Employment in Industry. San Jose, California: Manpower Research Group, Center for Interdisciplinary Studies, San Jose State College, 1966, pp. 7-31.

Martin Company. The Mussile Industry in Defense and the Exploration of Space. Baltimore: The Martin Company,

Marzani, Carl, and Perlo, Victor. Dollars and Sense of Disarmament. New York: Marzani and Munsell, Publishers, 1960.

Melman, Seymour. Our Depleted Society. New York: HoIt, Rinehart and Winston, 1965.

McEntire, Davis. The Labor Force in California: A Study of Characteristics and Trends in Labor force, Employment and Occupations in California, 1900-1950. Berkeley: University of California Press, 1952.

McWilliams, Carey. Californla: The Great Exception. New York: A. A. Wyn, Publisher, 1949.

Peck, Merton J., and Scherer, Frederic M. The Weapons Acquisition Process: An Economic Analysis. Boston: Harvard University Press, 1962.

Poland, Orville F. Economic q'rends in the San Francisco Bay Area. Berkeley: Institute of Governmental Studies, Franklin $K$. Lane Project, University of California, 1963.

San Jose Mercury and News. Advertising Plans Department. Facts About Metropolitan San Jose and the Bay Area. San Jose, Califoria, February, 1963.

- Market Memo: Current Trends and Prospects in Metro San Jose and the Nation. San Jose, Caifiornia, August, 1965 and August, 1968. 
Santa Clara County Chambers of Commerce. Research Committee. Data Sheet, Santa Clara County, 1957-1968. San Jose. 1968.

Scott, Meliler Goodin. The San Francisco Bay Area: A Metropolis in Perspective. Berkeley: University of

Shapero, Albert; Howell, RIchard P.; and Tombaugh, James R. An Exploratory Study of the Structure and Dynamics Stanfora Researci Institute, Park, California:

The Structure and Dynamics of the Defense $R \& D$ Industry: I'he Los Angeles and Boston Complexes. Menlo Park, California: Stanford Research Institute,

Southern California CED Associates. National Defense and Southern California, 1961-ig70, by George A. Steiner. Los Angeles: Southern California CED Associates, 1961.

Tiebout, Charles $M$. The Community Economic Base Study. New York: Committee for Economic Development, 1962.

Travis, Robert $W$. A Study of Industrial Site Development and Site Choice in Santa Clara County--1950 to 1959. San Jose, California: San Jose State College, Real Estate Research Bureau, n.d. (Mimeographed.)

United California Bank. Research and Planning Department. 1969 Forecast. Los Angeles, 1968.

Urban Land Institute. Findings Recommendations and Record of Proceedinss of the Inaustrial Develonment Study for San Wateo County, California. Washington, D.C.: Urban Land Institute, 1953.

Wells, Donald A. The War Myth. New York: Pegasus, 1967.

Whitnah, Joseph C. A History of Richmond, California.

Rtchmond, California: Richmond Chamber of Commerce, 1944.

\section{INTERVIEWS}

Smal1, Robert W. Private interview helo at San Jose State College, San Jose, California, April, 1969. 